University of San Diego

Digital USD

2001

\title{
The Effect of Professional Growth Opportunities as Determined by California Public High School Instrumental Music Teachers
}

Charles Friedrichs EdD

University of San Diego

Follow this and additional works at: https://digital.sandiego.edu/dissertations

Part of the Leadership Studies Commons

\section{Digital USD Citation}

Friedrichs, Charles EdD, "The Effect of Professional Growth Opportunities as Determined by California Public High School Instrumental Music Teachers" (2001). Dissertations. 672.

https://digital.sandiego.edu/dissertations/672

This Dissertation: Open Access is brought to you for free and open access by the Theses and Dissertations at Digital USD. It has been accepted for inclusion in Dissertations by an authorized administrator of Digital USD. For more information, please contact digital@sandiego.edu. 


\title{
THE EFFECT OF PROFESSIONAL GROWTH OPPORTUNITIES AS DETERMINED BY CALIFORNIA PUBLIC HIGH SCHOOL INSTRUMENTAL MUSIC TEACHERS
}

By

\section{Charles FrIEDRICHS}

A dissertation submitted in partial fulfillment of the requirements for the degree of

Doctor of Education

University of San Diego

2001

\author{
Dissertation Committee \\ Robert L. Infantino, Ed.D. Chair \\ Edward Kujawa Jr., Ph.D. \\ Terry O'Donnell, DMA
}


ABSTRACT OF THE DISSERTATION

\section{THE EFFECT OF PROFESSIONAL GROWI'H OPPORTUNITIES AS DETERMINED BY CALIFORNIA PUBLIC HIGH SCHOOL INSTRUMENTAL MUSIC TEACHERS}

Charles Friedrichs, Ed.D

Robert L Infantino, Ed.D., Chair

Improving the quality of teaching and instruction is a continuing challenge for schools and teachers. To meet this challenge the State of California requires all teachers to participate in professional growth activities by showing evidence of 150 hours of professional growth every five years (Ed. Code $§ 44277-2 b)$.

The purposes of this study were to examine the professional growth habits and needs of high school instrumental music teachers in the state of California, and the effectiveness of current professional growth opportunities as perceived by those teachers. In addition, this study examined the implications of professional growth opportunities for these music teachers and the various state music organizations that serve them.

A survey instrument explored the following questions. (a) What types of professional growth activities are high school instrumental music teachers attending in order to satisfy the state professional growth requirement? (b) What professional growth activities do high school instrumental music teachers find effective? (c) To what extent do high school instrumental music teachers participate in non-traditional professional growth activities such as peer mentoring and music education research? (d) Is there a difference in professional growth activities among high school instrument music teachers who work in urban, rural, 
and suburban areas of the state? (e) What are the implications of this study for the state music education organizations? ( $f$ ) What are the implications for district leaders with regard to providing staff development for the high school instrumental music teachers?

Findings indicate that the respondents attend a variety of professional growth activities. The most valuable and most effective activities were those relating directly to music: Hosting a Guest Clinician or Teacher, Observing Other Rehearsals, attending Music Conferences, Concerts, and Music Workshops. The least valuable and least effective activities were NonMusic Workshops, On-Campus Inservice, County Office Workshops, District Sponsored Workshops, and Non-Music Conferences.

Implications are examined in chapter 5. Written comments included in the appendix show teacher preferences for having more opportunities for personal interactions with their music colleagues. 


\section{(C) 2001 Charles Friedrichs}

Reproduced with permission of the copyright owner. Further reproduction prohibited without permission. 


\section{DEDICATION}

This dissertation is dedicated with deepest love and respect to my parents: to my late father, Raymond Charles Friedrichs who led me with his quiet strength and his unbreakable love for his family; to my mother, Mary Jane Friedrichs who inspires me with her limitless energy and perseverance and who has taught me how to endure with both love and tenacity. 


\section{ACKNOWLEDGEMENTS}

This dissertation could never have been completed without the support, guidance, inspiration, and assistance of many individuals. I would like to thank Dr. Robert Infantino who acted as my Chair and gave me his support with kindness and patience throughout the life of this project. My thanks to Dr. Edward Kujawa Jr. and Dr. Terry O'Donnell for their cogent and analytical reviews of my work.

A debt of gratitude is owed to my colleagues Harold Warman, Bryan Ransom, Tom Stauffer, Frank Almond, Mitzi Kolar, and Brent Dutton who provided me with support and encouragement throughout my degree program.

I wish to thank my students for supplying the focus and reason why all teachers, including myself, should continue to strive to be better teachers.

I wish to show appreciation for my colleague, fellow doctoral student, and dear friend, Nan McDonald for freely giving of her talents, wisdom, and support to me as we completed our degree and dissertation projects. Without her almost daily help, this undertaking would never have been completed. She deserves more than anything I could offer her for her generosity.

This entire endeavor could never have taken place without the inspiration of watching my son Kyle grow up during these past five years as I have pursued my degree. My hope is that his life will benefit from the results of this study.

Finally, my thanks to all of the music educators who gave freely of their time, opinions and expertise without which this study could not have taken place. 
TABLE OF CONTENTS

ABSTRACT OF THE DISSERTATION ……………...............................................................

DEDICATION ........................................................................................................................... viii

ACKNOWLEDGEMENTS ..................................................................................................................... ix

TABLE OF CONTENTS............................................................................................................................

LIST OF TABLES ..................................................................................................................... xiv

CHAPTER 1: INTRODUCTION..................................................................................................... 1

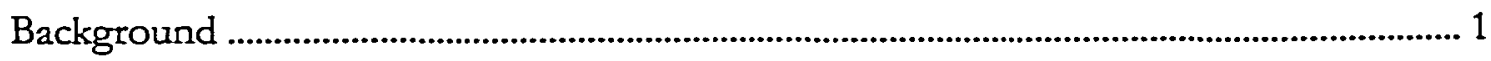

Statement of the Problem ..............................................................................................................

Rationale for Professional Growth ............................................................................................... 3

The Instrumental Music Teacher ................................................................................................... 5

Professional Growth Activities and Organizations …………………..................................... 7

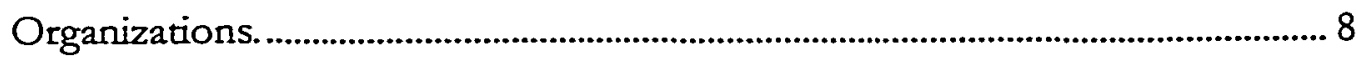

Purposes of the Study .................................................................................................................. 10

Research Design and Methodology Overview …………...................................................... 11

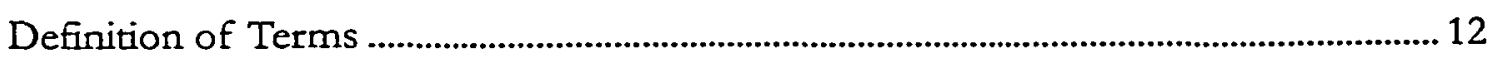

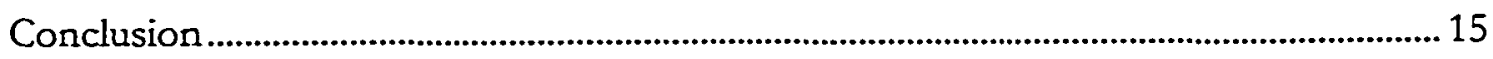

CHAPTER 2: REVIEW OF RELATED LITERATURE AND RESEARCH .......................... 16

Historical Background of Professional Growth ……………………………………………. 19

State of California Professional Growth Requirements ..................................................... 21

Professional Growth Categories.............................................................................................. 22 
Professional Growth Activities in Music Education

University coursework.

Conferences, Workshops, etc.

Mentoring.

Service in a leadership role in an educational institution and professional

organization. 28

Educational research and innovation. 29

Creative endeavors and cultural experiences.. 29

High School Instrumental Music Teachers. 29

Music Supervisors . 31

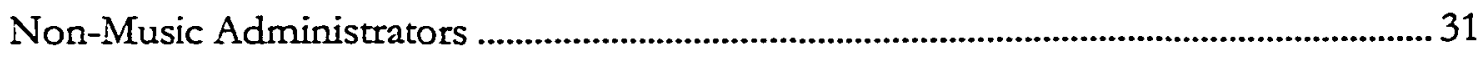

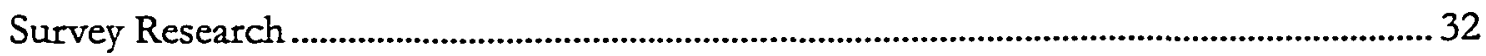

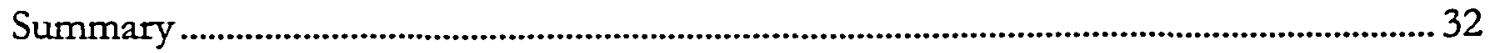

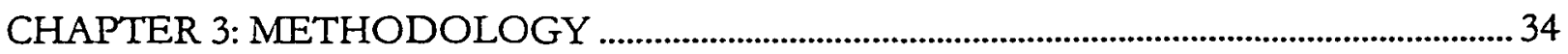

Development of the Survey Instrument ............................................................................... 35

Section I: Demographics ....................................................................................... 36

Section II: Variety of Professional Growth Activities ............................................ 37

Section III: Rating the Effectiveness ........................................................................ 37

Section IV: Most Valuable and Least Valuable Activities ..................................... 37

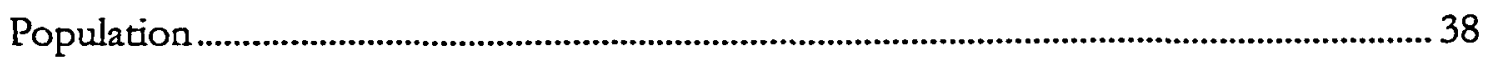

Response rate and Survey Limitations ................................................................................. 39

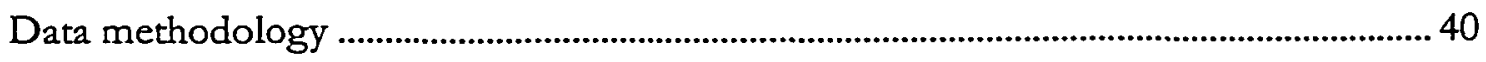

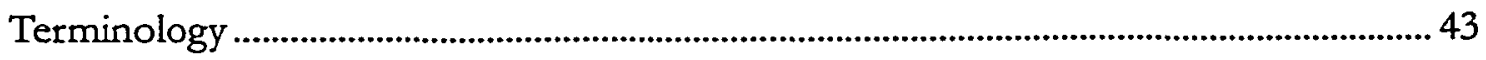

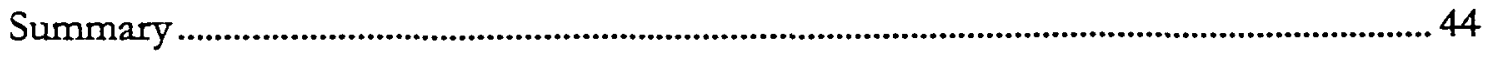

$\mathrm{xi}$ 
Part One: Demographics of the Subject Population

Demographic Summary.

Part Two: Types of Professional Growth Activities Attended. 64

Part Three: Effectiveness Rating of Professional Growth Activities. 68

Part Four: Cross Tabulations between Types of Professional Growth Activities

Attended During the Past Three Years and Demographic Categories..... 71

Part Five: Cross Tabulations between Most Valuable Professional Growth Activities and Demographics 101

Part Six: Comments Regarding Most Valuable Professional Growth Activity 129

Part Seven: Cross Tabulations between the Least Valuable Professional Growth

Activities and Demographics

Part Eight: Comments to Organizations That Provide Professional Growth Activities

for High School Instrumental Music Teachers. 158

Conclusion. 161

CHAPTER 5: SUMMARY, CONCLUSIONS, AND RECOMMENDATIONS .162

Summary 162

The Problem 162

The Purpose 163

Research Questions 163

Delimitations of the Study. 164

Limitations of the Study 164

Design and Data Collection Procedures 165

Selected Findings. 165

xii 


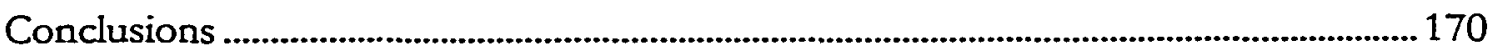

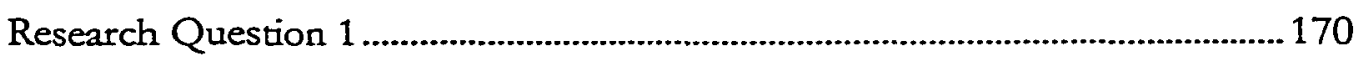

Research Question 2.................................................................................................... 171

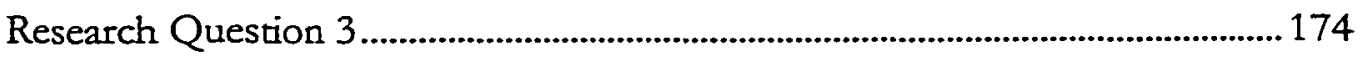

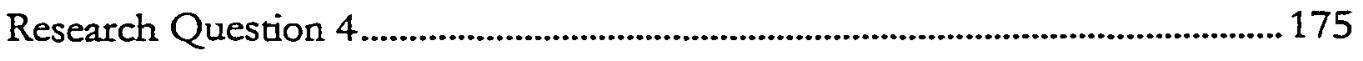

Research Question 5..................................................................................................176

Research Question 6................................................................................................... 179

Implications and Recommendations .................................................................................... 180

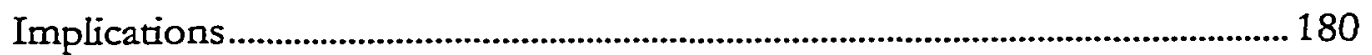

Recommendations ……........................................................................................... 181

Recommendations for Future Study............................................................................... 185

Closing Comments ................................................................................................................ 186

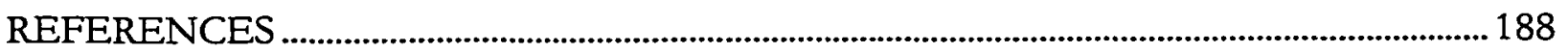

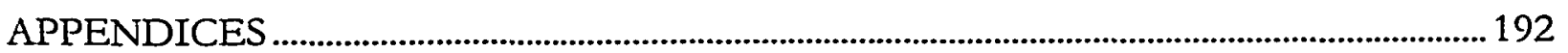

APPENDIX A: CONSENT FORM.................................................................................. 193

APPENDIX B: SURVEY INSTRUMENT ……………………………………………... 195

APPENDIX C: POSTCARD REMINDER.....................................................................201

APPENDIX D: EMAIL MESSAGE ................................................................................... 203

APPENDIX E: WHY YOU CHOSE YOUR NUMBER ONE PROFESSIONAL

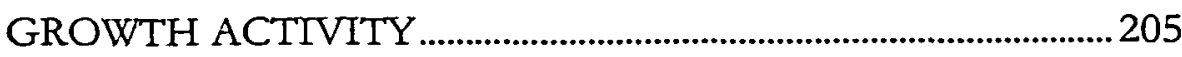

APPENDIX F: COMMENTS TO MUSIC EDUCATION ORGANIZATIONS ....227 


\section{LIST OF TABLES}

Table 1: Survey Mailing Activity ..................................................................................................... 39

Table 2: $\quad$ Number of Years as a High School Instrumental Music Teacher.............................. 47

Table 3: Number of Years in Current Job .......................................................................................... 48

Table 4: Types of California Teaching Credentials .......................................................................... 49

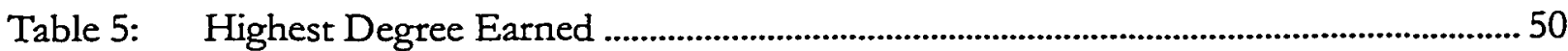

Table 6: District Reimbursement for Professional Growth Activities...................................... 51

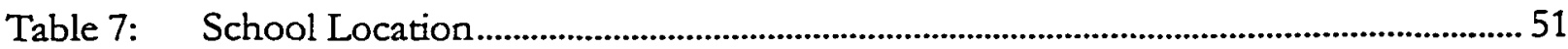

Table 8: Number of Music Teachers at Each School Site .......................................................... 52

Table 9: Number of Music High School Instrumental Teachers in Each District................. 53

Table 10: Number of Music Coordinators/Supervisors............................................................... 54

Table 11: Music Coordinators Who Provided Professional Growth Activities ......................... 54

Table 12: Music Teachers with Combined Music Supervisor and Teaching Duties ................ 55

Table 13: Total School Enrollment.................................................................................................. 56

Table 14: Total Instrumental Program Enrollment............................................................................ 57

Table 15 Membership in Music Education Organizations ......................................................... 58

Table 16 Other Professional Organizations .............................................................................60

Table 17 Collaborations with Universities/Colleges and Other Organizations....................... 62

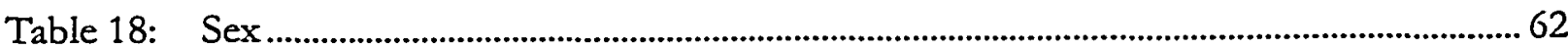

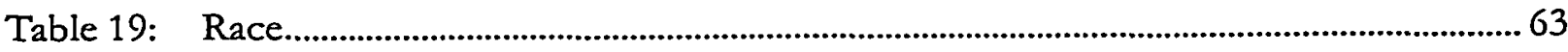

Table 20: Professional Growth Activities Attended by Respondents .........................................65 65

xiv 
Table 21: Activities That Provided the Most Benefit.

Table 22: Mean Score Showing Perceived Effectiveness and Ineffectiveness of Professional

Growth Activities. 70

Table 23: Staff Development Activities Attended by the Number of Years Teaching........... 74

Table 24: Staff Development Activities Attended by Number of Years in Current Job........ 77

Table 25: Staff Development Activities Attended by Level of Education................................ 79

Table 26: Staff Development Activities Attended by Type California Teaching Credential.. 82

Table 27: Staff Development Activities Attended by Amount of District Reimbursement. 85

Table 28: Staff Development Activities Attended by Number of High School Instrumental

Teachers in the District ................................................................................................. 88

Table 29: Staff Development Activities Attended by School Size ............................................. 90

Table 30: Staff Development Activities Attended by School Location ..................................... 93

Table 31: Staff Development Activities Attended by Number of Students in the Program. 96

Table 32: Staff Development Activities Attended by Sex............................................................ 98

Table 33: Staff Development Activities Attended by Race ........................................................ 100

Table 34: Most Valuable Professional Growth Activities by Number of Years Teaching.... 104

Table 35: Most Valuable Professional Growth Activities by Years in Current Job ................. 106

Table 36: Most Valuable Professional Growth Activities by Level of Education.................. 109

Table 37: Most Valuable Professional Growth Activities by Type of California Teaching

Credential

Table 38: Most Valuable Professional Growth Activities by Amount of District

Reimbursement.

Table 39: Most Valuable Professional Growth Activities by the Number of High School

Instrumental Music Teachers in the District. 
Table 40: Most Valuable Professional Growth Activities by School Size

Table 41: Most Valuable Professional Growth Activities by School Location.

Table 42: Most Valuable Professional Growth Activities by Number of Students in the Program

Table 43: Most Valuable Professional Growth Activities by Sex

Table 44: Most Valuable Professional Growth Activities by Race

Table 45: The Most Valuable Professional Growth Activity Comments from Section IV of the Survey .130

Table 46: Least Valuable Professional Growth Activities by Number of Years Teaching ... 136

Table 47: Least Valuable Professional Growth Activities by Years in Current Job 138

Table 48: Least Valuable Professional Growth Activities by Level of Education. 140

Table 49: Least Valuable Professional Growth Activities by California Teaching Credential .... 142

Table 50: Least Valuable Professional Growth Activities by Amount of District

Reimbursement.

Table 51: Least Valuable Professional Growth Activities by the Number of High School

Instrumental Music Teachers in the District.

Table 52: Least Valuable Professional Growth Activities by School Size

Table 53: Least Valuable Professional Growth Activities by School Location 151

Table 54: Least Valuable Professional Growth Activities by Number of Students in the Table Program

Table 55: Least Valuable Professional Growth Activities by Sex

Table 56: Least Vaiuable Professional Growth Activities by Race

Table 57: Comments for Professional Growth Organizations

Table 58: Professional Growth Activity Comparison Rankings 172

xvi 


$$
\text { Cbapter } 1
$$

\section{INTRODUCTION}

\section{Background}

Improving the quality of teaching and instruction is a continuing challenge for schools and teachers. Having knowledgeable and well-trained teachers is a basic expectation of our society. A Harris Research survey (Herdt, 1998, p. A3) found that "Californians ranked improving teacher quality above such education initiatives as class size reduction, more rigorous academic standards, greater parental involvement in the schools, and putting computers in every classroom." One third of the respondents in the survey said the problem of poor quality teaching is "serious and widespread" (Herdt, 1998, p. A3). Part of the process in obtaining and maintaining quality teachers involves their continuing education beyond the pre-service training and the certification process.

Once California teachers have earned a degree and a clear teaching credential, they are expected to continue to improve professional skills and participate in professional growth activities. In order for teachers to maintain a professional clear multiple subject or single subject teaching credential, they must successfully complete an individual program of professional growth consisting of a minimum of 150 clock hours within a five-year time frame (California Education Code $\$ 44277-2 b$ ).

In California, legislation requires teachers to participate in professional growth activities throughout their teaching careers. Teacher preparation and development is now seen as a life 
long process. The Legislature recognizes that effective professional growth must continue to occur throughout the careers of all teachers, in order that teachers remain informed of developments in pedagogy, subject matter, and pupil needs. In enacting this section, it is the intent of the Legislature to establish professional growth requirements that give individual teachers a wide range of options to pursue as well as significant roles in determining the course of their professional growth (California Education Code $\int 44277$ ).

Acceptable professional growth activities include participation in professional conferences, workshops, college course work, service as a mentor teacher, service in a leadership role in a professional organization, and participation in educational research or innovation efforts (Ed Code $\$ 44277-2 b)$. The Code's "wide range of options" allows leeway in order to accommodate the individual needs of teachers.

To serve their teaching staffs, school administrators commonly set aside blocks of time during the academic year for professional growth programs. These sessions have become an integral part of the teaching year and they provide valuable information and sharing of ideas. While most on-site activities are geared towards the teaching population as a whole, other in-service activities center on topics in specific academic areas such as mathematics, science, and English. Teachers in these fields attend workshops to share methods and materials that are distinct and relevant to their subject area. Grouping professional growth activities around those teachers with similar interests and problems is both convenient and efficient. Another advantage for groups with similar teaching problems and solutions linked together at a central site is the opportunity for ongoing discussion and sharing which extends beyond formal in-service activities. 


\section{Statement of the Problem}

While these activities are occurring and benefiting many teachers, there are groups of teachers whose areas of professional needs are not being met. These teachers teach subjects such as drama, dance, and music. An individual on some high school campuses typically teaches one or more of these subjects, creating a situation that restricts these teachers from participating in specific academic in-service activities because of the small number of discipline-specific teachers and limited district resources allocated to these specialty areas. In addition, many administrators are not prepared or qualified to offer specific in-service activities to teachers of these subjects.

Because of limited opportunities available to high school instrumental music teacher for local and convenient professional growth activities, these teachers have been left on their own to search out appropriate professional activities that they feel will both satisfy their needs and the 150-hour credential requirement.

As much as general teacher preparation, and to some extent, music teacher preparation specifically, have been discussed and studied (Okun, 1998; Nardo, 1996; Temple 1972; and Schafer, 1977), few studies exclusively address the problems high school instrumental teachers face in finding activities that meet their professional growth needs, that track their professional growth participation habits, and analyze the perceived effectiveness of professional growth activities of these teachers.

\section{Rationale for Professional Growth}

Beyond earning a degree and certification to become a teacher, educators are expected to pursue educational activities that to keep them current with the educational practices and needs of their communities and state. Participating in continuous educational development 
allows teachers to remain current in their subject area and in the many ways that have become available to communicate that subject to their students.

The California Education Code states "effective professional growth must continue to occur throughout the careers of all teachers, in order that teachers remain informed of changes in pedagogy, subject matter, and pupil needs" ( $(44277)$. This explicit statement mandating that teachers follow a career of professional growth reflects the needs and expectations of public schools, school districts, students, and parents.

In order to maintain a quality group of teachers in significant numbers, it is necessary that these teachers continue a systematic process of continuing education and professional growth that extends beyond their certification program. Professional growth is necessary for many reasons besides maintaining expertise in the field and being informed of changes in pedagogy and pupil needs. Additional reasons for participating in professional growth activities include the ability to share and learn new solutions to teaching problems; the opportunity to break down the walls of isolationism that commonly afflict many teachers due to the nature of their jobs; and time to renew enthusiasm for the teaching profession and to rediscover motivations for becoming a teacher in the first place.

"If a competent and committed pool of professionals cannot be maintained, both the quality of instruction given in the classrooms of this country and the quantity of qualified instructors available to offer such quality instruction will be limited" (Smith, M. 1994, p. 6). Without a teacher force that participates in an ongoing process of education, our schools will be staffed with teachers who are not current in their field and, even more frightening, who lack interest and passion for the educational success of their students. 


\section{The Instrumental Music Teacher}

Like other educators, high school instrumental music teachers have at their disposal a variety of professional growth options, including school site opportunities offered by their district. Yet, most on-campus or district activities are limited to general teaching problems or school-wide issues such as classroom management, school violence, or special needs students. This situation forces the high school instrumental music teachers to look offcampus for specific professional growth opportunities that would be useful to the nature of their job (Wohl, 1993).

High school instrumental music teachers work in environments that are quite different from other teachers. Bell (1986) identified 70 instructional tasks and 52 administrative tasks resulting in 17 intrinsic and 19 extrinsic outcomes for music teachers, many of which are specific only to the music teaching profession. Such environments require music educators to master many tasks such as fundraising, public relations, and fiscal management while under pressure to present performing ensembles in public display.

Although the purpose of Bell's study was to determine the extent to which consensus exists between high school band directors and professors of music education regarding the importance of specified instructional tasks, administrative tasks, and outcomes, Bell's study also makes explicit the variety of activities high school instrumental music teachers must perform. Curriculum development, attending booster meetings, keeping inventory of instruments, organizing concerts, and fundraising were some of the 42 administrative tasks not directly related to teaching. Instrumental music teachers view curriculum development as an annual process in acquiring, creating, and preparing new music for every performance group. This means arranging music if it is not available for purchase, or, if available, not appropriate for the skill level of their students, preparing and copying music for each 
instrument, and creating and designing field show patterns. All these tasks are in addition to teaching groups of students in classroom settings while simultaneously preparing for numerous performances for both the school and for the community. Not many other high school subjects require that educators be proficient in such diverse areas beyond the classroom.

In addition to these multiple tasks, the high school instrumental music teacher is often the only person on campus who teaches music. In some cases, the high school instrumental teacher is the only teacher in the entire district responsible for music instruction from kindergarten through high school. Due to lack of peer interaction, these conditions result in both professional and geographic isolation. This singularity also sets high school instrumental music teachers apart from other teachers and limits professional growth opportunities that are usually provided at campus sites.

Public display of the high school instrumental music teacher's work, and accompanying: performance pressures, are two factors that may cause stress, affect teaching effectiveness, and compel a music teacher to seek professional growth help. In a study investigating problems that cause stress among music teachers in Tennessee, Brown (1987) identified two factors that were most stressful: (a) those which reflect how teachers are valued by their school system and (b) those which reflect how music teachers are valued by the public. It is important to note that these factors were the perceptions of the teachers themselves. Brown also surveyed a panel of experts, including administrators, who identified factors that they perceived as stressful to music teachers. Contrary to the teachers' perceptions, the panel of experts felt those environmental issues, such as rehearsal space and budget limitations, were most stressful. Brown's study illuminates the gap that may exist between teachers' and administrators' perceptions thus illustrating the need for professional growth activities that 
are specifically oriented towards the needs of instrumental music teachers. Brown's study implies that a perception gap further isolates the needs of the music teacher from mainstream on-site staff development offerings because an administration, for whatever reasons, may validate in-service needs differently. This perception gap could cause school administrators to offer inappropriate on-site professional growth activities for high school instrumental music teachers rather than activities that would better meet these teachers needs.

\section{Professional Growth Activities and Organizations}

High school instrumental music teachers have a comprehensive set of professional duties, and in order to be successful, they must be knowledgeable about a variety of subjects and activities. Experiences for music teachers to keep current in their field cannot be provided by on-site in-service activities. Thus, high school instrumental music teachers must find off-campus sources such as conventions, conferences, clinics, and mentors to obtain professional growth.

Many activities fulfill the needs of the high school instrumental music teacher and satisfy the guidelines set down by the California Education Code. The education code includes activities such as

the completion of courses offered by regionally accredited colleges and universities; participation in professional conferences, workshops, teacher center programs, or staff development programs; service as a mentor teacher pursuant to Section 44496; participation in school curriculum development projects; participation in systematic programs of observation and analysis of teaching; service in a leadership role in a professional organization; and participation in educational research or innovation efforts (California Education Code $\left.\int 44277\right)$. 
These guidelines, while seemingly obvious and specific, could include a wide variety of musical activities such as composition, festival participation, adjudication, conducting honor ensembles, being a clinician, and having a clinician rehearse your ensemble.

\section{Organizations.}

Presently, professional music education organizations in the state of California regularly provide or sponsor professional growth activities. One organization that provides conference opportunities for high school instrumental music teachers is the Southern California School Band and Orchestra Association (SCSBOA). The current president, Richard Lorenzen, has verbally endorsed a study that would evaluate conference offerings. Additional support for such a study comes from George DeGraffenreid, current president for the California Music Educators Association (CMEA) and past president of the California Council on Music Teacher Education (CalCOMTE). Both organizations are looking for ways to improve their conference offerings, and both endorse a research study that would examine their constituents' needs and perceptions.

The largest music educators' organization in the United States is the Music Educators National Conference (MENC). This national organization offers a national conference and professional growth opportunities every other year for all music educators including those involved in this study.

The CMEA is the statewide music education organization that operates under the Music Educators National Conference. This organization offers yearly conferences for all levels of music educators including those involved in this study.

In addition, the CMEA operates as an umbrella organization for many regional groups throughout the state such as the Stanislaus County Music Educators Association, Kern County Music Educators Association, Imperial Valley Music Educators Association, San 
Joaquin County Music Educators Association, Tulare-Kings County Music Educators Association, etc. These regional organizations sponsor additional yearly activities that directly meet the needs of their members including those in this study.

The Southern California School Band and Orchestra Association (SCSBOA) is a group of instrumental music educators, based in the lower third geographic region of California, that offer two conferences each year for its members. While this organization offers professional growth sessions dedicated to concert and jazz bands and some of the same activities as the other organizations, it also addresses the needs of the instrumental music teacher who must enter their school ensembles in competitive parades and field shows.

In the northern part of the state, the Northern California Band Association (NCBA) offers workshops at least once a year for its members and the California Band Directors Association (CBDA) also offers seminars addressing the specific needs of the band director.

More musically specialized organizations also offer workshops. Some of these include the California Orchestra Directors Association (CODA) and American String Teachers Association (ASTA) for the orchestra and string teachers, and the International Association of Jazz Educators (IAJE) for the jazz ensemble directors.

In addition, high school instrumental music teachers belong to and participate in presentations put on by the Winter Guard Association of Southern California (WGASC) and the California Association of Drill Team Directors (CADTD). These organizations address specific needs of non-music units attached to competitive marching bands.

There are also many other music organizations that offer information and opportunities for additional learning for the high school instrumental music teacher. Some of these include the American Guild of Organists (AGO), The Southern California Vocal Association (SCVA), American Choral Directors Association (ACDA), The Dalcroze Association (DA), 
Women's Band Director's International (WBDI), the Western Association of School Band Ensembles (WASBE), the American School Band Directors Association (ASBDA), the American Band Association (ABA), to name a few.

A multitude of organizations provides some type of ongoing professional growth activity for every high school instrumental music teacher beyond those offered on site at their school or at the district level.

\section{Purposes of the Study}

The purposes of this study were to examine the professional growth habits and needs of high school instrumental music teachers in California, and to evaluate the effectiveness of current professional growth opportunities as perceived by those teachers. In addition, this study examined the implications of professional growth opportunities for high school instrumental music teachers and the various state music organizations that serve them. To achieve this purpose the following quescions were posed:

1. What types of professional growth activities are high school instrumental music teachers attending in order to satisfy the 150 -hour state requirement needed to maintain the Professional Clear Single Subject Music Credential every five years?

2. What professional growth activities do high school instrumental music teachers find effective in meeting their professional growth needs, and what activities do they find ineffective?

3. To what extent do high school instrumental music teachers participate in non-traditional professional growth activities such as peer mentoring and music education research?

4. Is there a difference in professional growth activities and needs among high school instrumental music teachers who work in urban, rural, and suburban areas of the state? 
5. What are the implications of this study for the state music organizations such as the Southern California School Band and Orchestra Association (SCSBOA), the California Band Directors Association (CDBA), and the California Music Educators Association CMEA?

6. What are the implications for school district leaders such as principals, district administrators, and curriculum coordinators with regard to providing staff development opportunities for the high school instrumental music teachers?

\section{Research Design and Methodology Overview}

This study primarily employed a positivist approach to measure the impact of the research questions previously stated in order to generalize findings taken from the population (Creswell, 1994). This needs-assessment study engaged a controlled method that examined the perceptions, habits, and expectations of the study group from within their contextual experiences. The resulting data were used to assess the landscape of professional growth and provide a clearer picture of that landscape for both the members of the study group and the affiliated organizations.

The method employed a self-designed survey instrument where respondents could confirm, rank, and identify information on a quantitative level. In addition, in order to include data that might be overlooked by a quantitative approach, a portion of the survey instrument consisted of written qualitative response sections that allowed the respondents to contribute written opinions.

A survey was the preferred method of data collection because it was the best way to study a population in order to learn something about that population (Wang, 1996). 
Because the population was limited to public high school instrumental music teachers in the state of California, the survey was a single-stage sampling process. "A single-stage sampling procedure is one in which the researcher has access to names in the population and can sample the people directly" (Creswell, 1994, p. 119).

Participants. The participant group for this study was every high school instrumental music teacher in the state of California. $(n=960)$ These numbers were obtained from the California Basic Education Data Service (CBEDS) in Sacramento, California. This government agency identified 860 high schools with instrumental music programs in the state of California with 964 credentialed teachers employed during the 1998-1999 school year. This number represented the most recent available data at the time of this study.

\section{Definition of Terms}

High school instrumental music teacher. Teachers in the state of California who have earned a teaching credential and who are employed at a public high school teaching in the area of instrumental music.

Instrumental music. An area of music that includes all wind, string and percussion ensembles. For the purpose of this study the following ensemble terms will be used interchangeably: concert band, symphonic band, marching band, orchestra, string ensemble, chamber music ensemble, jazz band, jazz ensemble, pep band, beginning band, and pit orchestra.

Teaching credential. A professional level of certification earned by a teacher to teach in the state of California. Although there are differences between the types of credentials, for the purposes of this study the following credentials will be used interchangeably: preliminary single subject, professional clear single subject, life credential, district intern credential, emergency permit, and credentials with supplementary authorization in music. 
Single Subject Credential. This is the type of credential most high school instrumental music teachers earn. This credential allows for the teaching of one subject in the public schools. The single subject credential in music allows the holder to teach either vocal, instrumental, or general music in the public schools from Kindergarten through $12^{\text {th }}$ grade.

Preliminary Single Subject, District Intern, and Emergency Permits. These credentials are temporary, and should lead to the Professional Clear Credential upon completion of all certification requirements. Holders of these credentials are certified for a limited amount of time, and in order to maintain certification they must provide evidence of graduate coursework and professional growth activities.

Professional Clear Single Subject Credential. This class of credential indicates that the holder has satisfied all course requirements and that the credential is valid as long as the holder provides evidence of 150 hours of professional growth and six months of public school teaching every five years.

Life Credential. This credential is no longer issued, yet there are many teachers that still hold this class of certification. This credential has no professional growth requirements, is not renewable, and is valid for the life of the holder.

Supplementary Authorization. Holders of other credentials can earn an authorization to teach in an additional subject area upon approval by the California Commission on Teacher Credentialing through approved coursework completed outside of their primary credential. Holders of these supplemental authorizations are not required to provide evidence of professional growth in areas of secondary subjects.

Professional Development. Activities that contribute to the teacher's knowledge and skill beyond those learned or obtained during undergraduate or graduate certification 
coursework. Professional development, professional growth, staff development, and inservice will be used interchangeably throughout this study.

Music Conferences. These are large-scale events lasting two to four days and cater to all music teachers. Sessions are offered for music teachers of all grade levels and areas of specialization. Music conferences also offer product presentations and displays, new music sessions, presentations of non-music issues such as fund raising, and networking opportunities for various subgroups within the larger music education community.

Music Workshops. These are small-scale events usually lasting one day and the presentations are geared to address the needs of a specific portion of the music education community.

On-Campus In-Service. These activities are meetings and presentations that occur on the high school instrumental teacher's campus and include the entire resident faculty.

New Music Reading Sessions. These are specific presentations of new music available for purchase by publishing companies. These usually take place within the context of music conferences but can be offered elsewhere and under other situations.

Online/Distance Learning. These are activities that employ technology to access coursework offered at sites, or through organizations, where physical attendance is neither convenient nor practical. Some of the technology employed is video-conferencing and the Internet.

Beginning Teacher Support and Assessment (BTSA). This is a state mandated program that pairs experienced teacher with a new teacher in order to assist the new teacher in his or her job and provide a personal resource and mentor to the new teacher. 


\section{Conclusion}

Although high school instrumental music teachers may be aware of, and active participants in, off-site professional growth activities, they and others in the music education field do not necessarily know to what extent various in-service activities could impact their professional lives. Nor do researchers know how high school instrumental music teachers view professional growth activities. These needs are major reasons for undertaking this study.

The first chapter of this study presents a rationale for an investigation into the professional growth habits and needs of public high school instrumental music teachers in the state of California. Chapter II is a review of the literature related to the purposes of this study. A description of the methodology involved in the study is presented in Chapter III. Chapter IV presents the evaluative findings accumulated from the study. Chapter V presents the conclusions derived from the data along with recommendations and implications for further research. 


\section{Chapter 2}

\section{REVIEW OF RELATED LITERATURE AND RESEARCH}

Professional growth is a way of life for many teachers. While many districts provide onsite opportunities, others allow the teacher to take time-off for such activities and, in some cases, provide travel money for attendance at conferences and workshops. However, this has not always been the case. Expectations have evolved during the last 40 years to bring the teaching profession more in line with other professions and the expectations of the public, administration, and the teaching profession itself.

The purposes of this study were to examine the professional growth habits and needs of California high school instrumental music teachers, and to evaluate the effectiveness of current professional growth opportunities as perceived by those high school instrumental music teachers. In addition, this study examined the implications of professional growth opportunities for high school instrumental music teachers and the various state music organizations that serve them. This chapter presents an examination of the literature written about professional growth activities and, in particular, research related to professional growth for the high school instrumental music teacher.

Many studies have focused on music teacher preservice training experiences, factors affecting music teacher jobs, and professional growth activities of teachers in general (Adderley 1996, Marks 1994, Gregory 1986, Kennedy 1996, and Schafer 1977). Few studies 
describe, prescribe, identify, or examine professional growth activities for high school instrumental music teachers.

Adderley (1996) surveyed music teachers in South Carolina in order to determine the quality of their undergraduate preparation and whether or not they felt ready to teach the Music Education Standards as established by the Music Educators National Association.

Surveying California's music teacher training institutions programs to prepare their undergraduates and certify them as teachers was a study done by Marks (1994). While Schafer (1977) developed a curriculum model to guide undergraduate music teacher preparation programs in their development of California music teachers.

Gregory (1986) studied job satisfaction factors among high school instrumental music teachers. He found 14 factors that were affecting the job satisfaction of these high school teachers. Some of the primary factors were (a) the competitive aspects of a band program, (b) maintaining musical performance skills of the director, (c) musicianship of the director, (d) maintaining proper perspective, (e) failure to realize excitement and reward from band directing, and $(f)$ use of vacation and weekend time for band activities.

Kennedy (1996) studied factors affecting the professional growth decisions of nonmusic teachers. She surveyed mid-career educators in order to determine what influenced these teachers' professional growth choices while also considering other factors that were influenced by their job situations.

Another study involving professional growth for teachers of all subjects was done by Jeanne Smith (1998). She tried to uncover elements that encouraged teacher development and how insights gained were integrated into the classroom. She found that professional accomplishments, educational endeavors, and reflective activities were major sources of professional growth and should be implemented as activities for all teachers. 
Many studies that deal with in-service activities appear to focus on the mentoring of new teachers (Niday 1996, Tauer, 1995, Wade 1993, and Vardi 1992). Vardi's study (1992) explored the factors in developing a process that would bring mentors and mentees together through a parallel experience that would be transformational for the mentee but especially for the mentor.

On a less esoteric note, Niday (1996) sought to advance the understanding of the nature of mentoring relationships for novice teachers by identifying and describing the expectations and experiences that mentors and mentees bring to the relationship. Tauer's (1995) approach in examining mentoring was to study the effect of the mentoring process entirely from the perspective of the mentor. This resulted in a mentor structure where the success of the relationship between the mentor and mentee was determined by how well the mentor matched the expectations and needs of the new teacher. Another study that explored the voice of the mentor was one done by Wade (1993). This study was an investigation into the mentor's perceptions about learning to be a mentor and the process of mentoring.

Hayes (1996) examined factors that contributed to professional growth for both the new and the experienced teacher. This qualitative study also addressed policy maker's needs for information about (in-service) program implementation and effectiveness. Hayes identified eight themes affecting professional growth that emerged from her data. These themes were (1) managing personal change, (2) professional development, (3) teaching, (4) mentoring/helping others succeed, (5) renewed enthusiasm, (6) reflection, (7) time management and flexibility of time, and (8) staff development.

While many of these studies intersect with the study of the perceptions of the professional growth effectiveness for high school instrumental music teachers, there are no studies devoted exclusively to this subject. This study incorporates and explores new data, 
which should provide a clearer view of the professional growth habits and perceptions of this population.

\section{Historical Background of Professional Growth}

Professional growth expectations are prevalent in many professions and have been practiced for many centuries. Accountants, physicians, attorneys, and other trades traditionally require certification, and expect their members to demonstrate evidence of continuing education in order to maintain certification. The teaching profession is no exception. Recently as 1963, a significant professional growth expectation was articulated when the Yearbook of Education 1963: The Education and Training of Teacbers began publication. This prescient book addressed teacher expectations to continue learning beyond college preparation courses, due to the invention and distribution of the microprocessor and other new technologies. As a result of the publication of the Year Book of Education 1963: The Education and Training of Teachers, a system of organized professional growth expectations and activities was initiated. The last two decades has seen a major expansion of professional development activities and expectations.

As recently as 1975, a group of member countries of the Organization for Economic Cooperation and Development (OECD) contributed to a review that focused on the development and needs of teachers' professional growth (Bolam, 1980). The report focused on the input of governments and major educational agencies to their commitment of teacher in-service activities. The findings reported on six areas that impact professional development of teachers: (a) Needs based upon the career patterns of teachers. These were categorized into three areas of the teacher's career from the first four years of teaching through the mid-career teacher and concluding with those needs of the post-mid-career teacher; (b) Who are the providers of professional development; (c) Who trains the trainers; 
(d) Funding; (e) Evaluation of professional development; and (f) What in-service activities work best.

The Bolam report raised serious issues regarding professional growth. It stated that "expenditure(s) on research into in-service has been minimal, so it is hardly surprising that we have so little systematic and reliable information about costs, resource use, and effectiveness, both of particular approaches and overall investment” (Bolam, 1980 p. 95).

In 1976, survey of teachers, higher education professors, and the public in California found that nearly a third of the teachers had not participated in any type of in-service activity at an institution of higher learning during the previous three years Joyce, Howey, and Yarger, 1976). This low participation level came at a time when nearly all in-service activities were provided by institutions of higher learning and district supervisory personnel. The survey illustrated that even though teachers were participating in professional growth activities, they were doing so haphazardly and at less then $100 \%$ participation. Joyce (1980) found that teachers received the most effective teaching skill development from other teachers. Yet, on the whole, teachers "do not visit one another and observe each other while teaching and very few teachers receive much feedback about their performance" Joyce, 1980, p. 24).

The 1970's became a time for refocusing the direction of professional growth with the goal of systematically charting a path for teachers to follow throughout their careers. The state of California undertook a series of studies that attempted to better understand all the facets involved in providing professional growth activities (Joyce, 1980). Some of these elements included the very organizations responsible for delivering professional development services and the kinds of services actually presented at school sites. Additionally, attempts were made to "understand" the types of professional growth activities 
teachers participated in in order to enhance their subject matter competence and teaching skills.

In the mid 1980's, the state of California discontinued life credentialing and began requiring professional growth for all new teachers throughout their professional career.

\section{State of California Professional Growth Requirements}

Created in 1970, the California Commission on Teacher Credentialing (CCTC) is the public agency responsible for all aspects of teacher certification including educational standards, maintenance of records, and re-certification in terms of professional growth requirements.

Since August 31, 1985, all teachers in the state of California who hold a Professional Clear Teaching Credential (either multiple or single-subject) are required by the CCTC to establish, complete, and document a plan of professional growth activities. A minimum of 150 hours of clock time of professional growth activities must be completed, approved, and documented every five years in order for the Professional Clear Teaching Credential to be renewed.

In the manual for professional growth the CCTC states that in order to satisfy the credential renewal requirements of state law and regulations, a credential holder's professional growth program must meet each of the following five standards. The following CCTC standards are found on page eight of the California Professional Grouth Manual for Multiple and Single Subject Credential and Services and Specialist Credentials.

1. "Each activity must be likely to contribute to the competence, performance, or effectiveness of the credential holder in one or more of the domains of professional growth described on pages 9-11." Each activity must fit one of the seventeen domains, or additional guidelines, in order to qualify for acceptable professional growth. 
2. "Each activity must begin after the issuance date of the initial five-year professional clear credential, or the issuance date of the subsequent renewal of this credential."

3. "Each activity must be of high quality and consistent with the credential holder's professional growth goals, as stated in Item 8 of the Professional Growth Plan." These goals are established prior to participating in any in-service activities and should be approved by the participant's professional growth advisor. An advisor could be a principal, an identified mentor teacher, other teacher, a retired credentialed teacher, or a college or university personnel who hold credentials.

4. " Each activity must be included in one or more of the categories of professional growth activities described on pp. 12-16." A more in-depth discussion about these categories follows below.

5. "The credential holder's Professional Growth Plan and Record must ultimately include activities in at least two of the categories on pages 12-16." A more in-depth discussion of the categories found on pages 12-16 of the professional growth manual follows below.

These standards issued by the CCTC provide "credential holders and their advisors considerable latitude to exercise professional judgment and discretion as activities are being planned" (CCTC, 1999, p. 8).

\section{Professional Growth Categories}

The California CCTC designates seven categories of acceptable professional growth activities. These categories cover a broad spectrum of possible in-service activities and credential holders would be hard-pressed not to find something they could utilize.

These categories also appear to mesh well with research done by Sharon Oja and others on adult development. Finding an acceptable professional growth activity from the CCTC 
list seems to provide learning opportunities for teachers that reinforce the two main theories of developmental ages and developmental stages of adult development. "Staff development programs need to be based upon some key features which allow for more thinking about alternative perspectives, more genuine problem-solving on classroom and school concerns, and more empathetic role-taking" (Oja, 1989, p.150).

Below are the seven categories of acceptable professional growth activities (CCTC, 1999, pp. 12-16).

1. Completion of one or more college or university courses. The CCTC provides a conversion table that changes the units earned taking college courses into clock hours acceptable for credential renewal. For example one semester unit is worth 15 clock hours.

2. Conferences, workshops, institutes, academies, symposia, teacher center programs, or staff development programs.

3. Systematic programs of observations and analysis of teaching or performance of peer-alike job.

4. Service in a leadership role in an educational institution.

5. Service in a leadership role in a professional organization.

6. Educational research and innovation.

7. A miscellaneous category, which includes the following 6 areas.

A. Participation in a professional exchange program.

B. Participation in alternative work-experience programs.

C. Participation in a program of independent study.

D. Creative endeavors that creates a tangible product and relate to the teacher's subject or teaching assignment.

E. Participation in cultural experiences. 


\section{F. Instruction in cardiopulmonary resuscitation.}

\section{Professional Growth Activities in Music Education}

Finding the time to participate in professional growth opportunities as a high school instrumental music teacher is becoming increasingly difficult. In part, this is due to one or more of the following: (a) the extra time demands of the profession that limit interaction with other directors, (b) fewer music supervisors and administrative personnel, (c) limited or irregular professional conference offerings, (d) disconnection from other music teachers due to distance and/or other geographical barriers, (e) fewer resources and ( $f$ ) increasing public performance demands. These burdens are acknowledged by new high school instrumental music teachers as well as by experienced teachers who may feel burned out (Nimmo 1986).

\section{University coursework.}

As discussed earlier, until about 1975 the primary provider of professional growth activities has been either district supervisory personnel or institutions of higher learning. Higher education institutions also provide opportunities to earn advanced degrees, which in turn translate into increased salaries for teachers.

In addition, these institutions have begun to offer courses and seminars - sometimes in conjunction with other agencies - that do not lead to an advanced degree yet are acceptable as both professional growth activities and applicable towards advancement on the salary scale. Continuing education and on-line/distance learning are two typical examples. Such courses are offered under many auspices and seem to satisfy a need for non-traditional professional growth classroom experiences.

One such collaboration occurred between the San Diego County Office of Education, county high school instrumental music teachers, and San Diego State University in the summer of 1998 . The program was designed by San Diego County music teachers and titled 
Instrumental Music Programs: Academy for/ by County Teachers (IMPACT). The program involved a group of seven relatively inexperienced band directors (less than two years teaching), four experienced band directors (more than 15 years of teaching experience), and two university professors brought together into a two-year peer-mentoring program. The results of this program have yet to be compiled, but initial reaction has been positive and enthusiastic. Participant comments such as "a definite feeling of collegiality was formed," and "the exchange of ideas on all sides was very effective" are typical of the program. The IMPACT program also qualifies as a mentor program which satisfies every standard published by the state of California for acceptable professional growth activities.

\section{Conferences, Workshops, etc.}

In California, there are four primary music education organizations that provide conference opportunities for high school instrumental music teachers. They are: (a) the California Music Educators Association (CMEA) which is a subgroup of the national organization, Music Educators National Conference (MENC); (b) The California Band Directors Association (CBDA); (c) the Southern California School Band and Orchestra Association (SCSBOA) and (d) The Northern California Band Directors Association (NCBDA). Regional subgroups of CMEA also provide conference opportunities for high school instrumental music teachers. In addition, MENC hosts a national conference every other year attended by many high school instrumental music teachers from California. Unfortunately, this national conference has not been held on the West Coast since 1980 when it was held in Anaheim, CA.

The CMEA conference is held every year and alternates between Northern California and Southern California sites. SCSBOA hosts two conferences each year, one in September and one in February. CBDA also hosts a yearly conference in Northern California. These 
conferences satisfy the California state professional growth activities requirement for music teachers. Yet they are one-time presentations offered within limited time constraints and are often the least effective means for changing teaching practices.

\section{Mentoring.}

"Mention the word mentor to people in large businesses and they will, no doubt, recognize the term. It has recently become a popular and widely used expression in the professional world" (Smith, M., 1994, p. 20). This powerful relationship tool involving interpersonal exchange has not been lost on the education community. Studies by M. Smith (1994), Niday (1996), and Tauer (1995) point to the effects of mentoring relationships, both as an effective means of professional growth and ineffective means.

Michael Smith's study (1994) piloted a program that focused on mentoring beginning music teachers. The results of that study indicate that mentoring participants exhibited a strong preference for collaboration. Niday (1996) found that mentoring relationships are highly complex and cannot be viewed simply as being effective or ineffective due to the wide variety of expectations, successes and failures, and relationship issues that are brought to the shared experience. A study about the mentor-protégé relationship (Tauer, 1995) revealed that successful mentoring experiences are directly related to the success or failure of the relationship.

The role of the master teacher within a mentoring activity was studied by Hayes (1996). In this study she described the roles of eight master teachers and explained how their experiences contributed to the success and learning of the mentoring experience. The study revealed eight themes that mentoring programs should implement in order to be more effective. 
Applying mentoring approaches towards professional growth activities — such as CCTC's activity number three — is a natural connection because by definition mentoring refers to the care and education of another. Descriptions of mentoring research (Smith, J. 1998, Smith, M. 1994, Hayes 1996, and Niday 1996) indicate that mutually rewarding and equally valued relationships are common avenues for professional growth and appear to offer more to the music educator in terms of a conducive professional growth climate than just conference attendance. Vardi (1992) identified some of the qualities emanating from effective mentorships including energizing, inspiring, and change based upon reciprocity. These qualities might have more impact on participants of professional growth activities than do traditional activities like conference attendance.

While the mentoring process has been a strategy available for teacher's professional development, the professional lives of high school instrumental music teachers offer few opportunities to incorporate mentoring. There appear to be two exceptions. One is the "apprentice judging process" established by the Southern California School Band and Orchestra Association. This mentoring system trains high school instrumental music teachers to be adjudicators for music festivals and competitive events. Judges participate in a mentoring process with an experienced high school instrumental music teacher in preparation to adjudicate concert festivals and marching competitions.

High school instrumental music teachers also participate in a mentoring experience, which occurs in competitive, albeit friendly and informal, contexts like field show competitions. At the conclusion of competition parades and field shows, many directors will consult each other regarding ways to improve their group's performance. The expected result of those consultations is to provide information which will help musical ensembles earn 
higher scores at the next competition. This idea exchange occurs on an almost weekly basis during the months of September through December.

The other months of the school year offer additional opportunities for meeting and exchanging of ideas. Most high school instrumental music teachers participate in festivals where their groups are evaluated specifically on individual merit and expectations of musical standards, but not against other groups. These festivals occur during the months of February through May. While festivals are not supposed to be competitive, like parades and field shows, the exchange of ideas following these festivals can be difficult for some directors because discussions of weaknesses is perceived as a taboo subject. So asking for help from other directors can add to the stress level of the director.

Compounding the issue of accessible professional growth opportunities are school districts that cannot, or will not, provide high school instrumental music teachers opportunities to study music-related topics or topics that would improve their musical leadership skills.

Service in a leadership role in an educational institution and professional organization.

Service in institutional or organizational leadership roles offers teachers the opportunities to be an active leader rather than just a participant. Mentoring also fits in this category along with curriculum development, developing legislative proposals, and any presentation or development that leads to the improvement of other teachers. Heifetz (1994) wrote that leading "from a position of authority requires knowing how to tend and deploy the power that comes with the position. Authority can be divided into two forms: formal and informal. With formal authority come the various powers of the office, and with informal authority come the power to influence attitude and behavior beyond compliance." 
(p. 101) Although there are leadership opportunities available in some of the other activities, it is these two categories that make leadership explicit.

\section{Educational research and innovation.}

This category blends nicely with creative endeavors because research and innovation to a musician is the ability to create and adapt musical works for their performing ensembles. Unfortunately, field-testing of new music can be limiting because of time demands on performance groups. While this category was created to stimulate teachers to investigate educational innovations, it may still apply to the high school instrumental music teacher who has the time and talent to compose or to arrange music.

\section{Creative endeavors and cultural experiences.}

This category is most appropriate for the high school instrumental music teacher. Opportunities for self-directed activities abound in the form of attendance at concerts, exchange concerts, creating music composition and arrangements, and performance as a musician, honor band conductor, or clinician.

Most of the previous categories will fulfill a self-directed program of professional growth quite nicely. Each teacher can choose a path by determining personal goals and selecting activities that will result in reaching those goals. The CCTC categories are broad enough to allow individual teachers a means to pursue ways to influence their teaching skills and content regardless of what stage they are in life or in their career (Marczely, 1996).

\section{High School Instrumental Music Teachers}

The realities of a high school instrumental music teaching assignment involve more than just teaching music, rehearsing music, and presenting an occasional concert. Instrumental music teachers respond to performance demands beyond those made by the 
curriculum. It is this researcher's experience that many educators begin preparing their students for performances long before the start of regular classes and continue that instruction right up until the school graduation performance.

Throughout a typical academic year these teachers will prepare music groups for athletic events such as football and basketball games, participate in competitive events such as parades and field shows, manage booster groups, oversee fundraisers, perform at various community events, take groups on performing tours, perform in non-competitive events such as music festivals, conduct the school musical theater production, and engage in additional activities that exceed typical parameters and guidelines of music curriculum instruction. To meet these demands, pre-service training and professional preparation programs offer classes that address the wide range of responsibilities encountered by the typical high school instrumental music teacher (Smith, M. 1994).

Even with adequate undergraduate training, the new high school instrumental music teacher is often overwhelmed by the realities of the job. Facing a job with so much musical and administrative responsibility and requiring so much time commitment forces the teacher to adapt operational and educational strategies in order to survive.

One professional growth technique that some high school instrumental music teachers employ is to seek out help from their peers in mutual interactions. The most effective mentoring approach is face-to-face (Smith, M. 1994). Nevertheless, how do high school instrumental music teachers initiate these vulnerable relationships given all the obstacles present in a typical high school instrumental music teacher's daily life? Performance commitments require numerous hours beyond those of the typical day. The ensembles these teachers direct are in constant demand by the school and community to provide 
performances for civic and spirit purposes. These performance conditions are in addition to those scheduled as part of the regular curriculum.

\section{$\underline{\text { Music Supervisors }}$}

The passage of Proposition 13 in California in 1978 (the tax initiative that rolled property taxes back to the 1976 rates resulting in fewer tax dollars being spent on education and the arts) created a slow erosion in the ranks of music supervisors. In a conversation with a prominent Southern California music supervisor, Danny Wagner, Coordinator of Visual and Performing Arts for the Baldwin Park Unified School District in Baldwin Park, CA., I was told that only 30 music supervisors existed in California in 1993. Even though an accurate census of this group does not exist these numbers are fewer than those music supervisors known to exist around 1980.

In the past, music supervisors have been responsible for many of the administrative tasks associated with coordinating a music curriculum. One of those tasks has been to provide in-service activities for their district's music teachers. Today, with fewer music supervisors or coordinators, music teachers are being provided fewer growth opportunities.

\section{Non-Music Administrators}

Other common and widely available in-service opportunities are those provided on-site by local school administrators. These activities focus on school-wide or district-wide topics relevant to a majority of the staff. In addition, when specific areas of teaching are addressed, the primary focus of professional growth activities is centered on areas of study involving large numbers of teachers such as social studies or mathematics. In effect, disciplines with limited numbers of teachers are shut out from participating in most subject-oriented, on-site professional growth activities. Music is a discipline that usually does not have on-site opportunities such as those provided for the more populated disciplines. Because of this, it 
has been my experience that administrators allow music teachers to go off-campus for professional growth activities.

\section{Survey Research}

This research study employed a survey instrument because it is the best way to obtain the information needed. "Even when the information is available through other means, survey research may be an easier, quicker, less expensive, or more accurate way to get the required information" (Alreck, L. and Settle, R. 1995, p. 3). This study sought the opinions, activities, and attitudes regarding professional growth activities among public high school instrumental music teachers in the state of California.

Employing research methodology has become a generally accepted practice ever since George Gallup began his American Institute of Public Opinion business in 1935 (Rea and Parker, 1992). After he correctly predicted the outcome of the 1936 presidential race between Roosevelt and Landon, Gallup's method of using small sampling sizes became the survey method of choice. Since then, advancements in creating surveys and manipulating survey data have provided an even greater accuracy than Gallup's 1936 efforts.

There are three types of sample survey research, (1) mail-out, (2) telephone, and (3) inperson surveys. The survey instrument employed in this research study is a mail-out survey because of the following benefits. A mail-out survey provides the benefits of being cost efficient and convenient for the respondent. A mail-out survey can be prepared to "give the impression of authority while providing the respondent with anonymity and ample time to complete. Finally, the mail-out survey reduces interviewer bias" (Rea \& Parker, 1992, p. 8).

\section{Summary}

The concept of professional growth for teachers is not new. Yet it is only since 1985 that California's teachers are having to show evidence that they are staying current in their 
field through participation in professional growth activities. This relatively recent new policy points the teaching profession towards a more professional image of teacher competence and towards increased development of student achievement.

This chapter positions the growth of in-service activity expectations of music teachers within the larger context of the educational system and highlights the teaching environment and components of the high school instrumental music teacher within the educational system.

This study was designed to illuminate the professional growth activities that high school instrumental teachers commonly use as they meet the 150 hour state requirement for renewal of their credentials.

The information from reports and dissertations studied in Chapter II guided the research questions and design of this study. Chapter III describes the methodology used to gather the data. 


$$
\text { Chapter } 3
$$

\section{METHODOLOGY}

The professional growth needs of teachers in general - and high school instrumental music teachers in - particular remains a challenge and is of continuing concern to administrators, educators, and the public. Efforts to affect improvement in this area have included many administrative and legislative strategies. One reform measure that seems to have had the biggest impact on California's teachers has been Senate Bill 813 (passed in 1983). This legislation mandated that in order to maintain their credential every five years all holders of the Professional Clear Credential must complete 150 hours of professional growth and teach at least 90 days in the public schools (California Education Code $\$ 44277$ 2b).

While mandating participation in professional growth is notable, it remains to be seen which activities are providing teachers with meaningful and effective in-service. In order to determine the attitudes, effectiveness and the participation level of the state's high school instrumental music teachers regarding professional growth activities, this study undertook an examination of those areas while asking the following six questions.

1. What types of professional growth activities are high school instrumental music teachers attending in order to satisfy the 150 -hour state requirement needed to maintain the Professional Clear Single Subject Music Credential every five years? 
2. What professional growth activities do high school instrumental music teachers find effective in meeting their professional growth needs, and what activities do they find ineffective?

3. To what extent do high school instrumental music teachers participate in nontraditional professional growth activities such as peer mentoring and music education research?

4. Is there a difference in professional growth activities and needs among high school instrumental music teachers who work in urban, rural, and suburban areas of the state?

5. What are the implications of this study for the state music organizations such as the Southern California School Band and Orchestra Association (SCSBOA), the California Band Directors Association (CDBA), and the California Music Educators Association CMEA?

6. What are the implications for school district leaders such as principals, district administrators, and curriculum coordinators with regard to providing staff development opportunities for the high school instrumental music teachers?

\section{Development of the Survey Instrument}

This study utilized a survey instrument composed of four sections: (a) a demographic section, (b) a participation section that asked respondents to identify professional growth activities they attended during the past three years, (c) a section where respondents rated the effectiveness of professional growth activities, and (d) a section where respondents selected their most valuable and least valuable activities. The complete survey may be found in Appendix B.

A pilot assessment to validate the survey was made before beginning the main study. Fourteen San Diego County high school instrumental music teachers were chosen as subjects. All of the subjects were currently teaching band, orchestra, jazz ensemble, or string 
classes during the research study. The subjects signed a consent form (Appendix A) and were asked to complete the 30-minute survey and to identify any format difficulties, typographical errors or other problems. The survey was corrected and revised for use in the main study.

\section{Section I: Demographics}

The demographic section asked seventeen questions about the survey respondents and their current job (Appendix B). Questions were asked about how long they have been teaching, how long they have been in their current job, what California teaching credentials they held, highest level of education, amount of district reimbursement for professional growth expenses, school location, number of music teachers at school and in district, size of instrumental program and size of school. These questions provided background on the professional conditions that exist in the population.

Two questions were also asked about the existence of a district music supervisor and whether or not the supervisor provided professional growth activities or if another teacher served as music supervisor. This question indicates the presence or absence of an administrator directly responsible for the music teacher. Another question asked about additional levels of responsibilities assumed or assigned to the music teacher.

Two questions asked about the respondent's membership in music education associations and other professional organizations. Another question asks about participation in any school or university collaboration programs that were directly geared toward music teachers. These questions identified the number of associations available to the music teacher and the variety of levels of membership in these associations. In addition, this data provided districts with options for professional growth opportunities for their teachers.

Finally, each respondent was asked to indicate his or her race and gender. While these are standard demographic variables, they are included here in order to ascertain if these 
respondents in the subgroups answer in similar or dissimilar ways in terms of their participation or perceptions of professional growth activities.

\section{Section II: Variety of Professional Growth Activities}

The second section of the survey asked each respondent to indicate each professional growth activity they had attended during the previous three years. The respondents were given a list of 20 different types of activities to choose from and the option of choosing none or of listing another activity that was not mentioned.

Respondents were then asked to identify in writing a singular activity that benefited them the most. This section of the survey concluded with the option of explaining why the respondent did not attend any professional growth activity if they had selected NONE from the list of activities.

\section{Section III: Rating the Effectiveness}

Section III of the survey listed the 21 activities that were listed in section II including an option for the respondent to identify another activity not previously listed. The respondents were asked to rate the effectiveness of each of these 21 activities using a Likert scale from 1 , which represented the least effective to 5 , which represented the most effective.

\section{$\underline{\text { Section IV: Most Valuable and Least Valuable Activities }}$}

The final section of the survey instrument (section IV) asked the respondents to identify the top 3-5 activities they found most valuable and the 3-5 professional growth activities they found least valuable. Each of the previous 20 activities was listed again along with an option for the respondent to identify an additional activity that was not listed.

This section concluded with two qualitative questions asking the respondents to (a) write a brief statement indicating why they chose their number one rated professional 
growth activity as their most valuable, and (b) a question asking if they had any comments to make about professional growth activities directed to the organizations that sponsored those activities.

\section{Population}

The survey instrument was mailed out to every public high school instrumental music teacher in the state of California $(N=960)$. School addresses were obtained from the California Basic Education Data Survey (CBEDS), the California Band Directors Association, and the Southern California School Band and Orchestra Association. Each survey contained a consent form (Appendix A), the survey instrument (Appendix B), and a postage paid return envelope.

The initial mail-out was completed on February 15, 2000 and included a total of 960 surveys. Reminder postcards (Appendix C) were mailed to 812 teachers on March 14, 2000 followed by a second mailing of 488 surveys on April 18, 2000. Instrumental music teachers who had returned the survey from the initial mailing were removed from the mailing list. The second mailing of 488 consisted of randomly selected addresses at the ratio of 2 out of 3 from the remaining addresses.

In an attempt to increase the number of participant responses in the study, 110 band directors were emailed reminders on May 4, 2000. This email message (Appendix D) asked the directors to return the completed survey or to request another copy. Out of the 110 emails, 62 were returned as undeliverable because the addresses were either out-of-date or non-existent. Six directors requested another survey form.

In addition, another survey was mailed to 15 band directors' home addresses on May 19, 2000. Returns from the second mailing, from the email reminders, and from the direct 
mailing could not be separated from the total number of returned surveys because they were not identified by mailing date.

\section{$\underline{\text { Response rate and Survey Limitations }}$}

The activities listed in Table 1 indicate the number of mailings, reminders and return results. Invalid addresses indicate schools that returned the survey because they were incorrectly identified as public schools but were in reality private schools, adult schools, continuation schools without instrumental music programs, or public schools without instrumental music programs.

Invalid surveys were completed surveys that lacked a signed consent form.

Table 1

Survey Mailing Activity

\begin{tabular}{lc}
\hline ACTIVITY & TOTAL \\
\hline First Mailing & 960 \\
Postcard reminders & 812 \\
Second Mailing & 488 \\
Invalid Addresses & 21 \\
Total valid addresses & 939 \\
Total returned & 251 \\
Invalid surveys & 9 \\
Valid surveys & 242 \\
Total response rate & $26.7 \%$ \\
Total valid response rate & $25.7 \%$ \\
\hline
\end{tabular}


"Mail surveys with response rates over 30 percent are rare. Response rates are often only about 5 or 10 percent" (Alreck \& Settle, p. 35). Table 1 indicates a response rate of $25.7 \%$, which lowers the rate of non response bias and increases the validity of the data collected. Because the survey researches behaviors and attitudes that directly relate to the survey population and because of budget constraints, there did not seem to be a need to make a third mailing.

Some limitations to the survey include the rime frame of the mailings. This time frame coincided with some of the survey population's busiest time of the year: music festivals. This may have affected the response rate because the music teachers may have felt it was more important to rehearse their groups for adjudication than to fill out a survey.

Additional limitations to the survey could have been from respondents misunderstanding the survey questions or from unfamiliarity with the survey topic due to lack of teaching profession experience.

\section{Data methodology}

Data analyses and discussion of the survey findings (see Appendix B) are presented in eight parts in chapter four of this study. Part One of Chapter Four presents the demographic data accumulated through responses provided by the respondents from section I of the survey in summary form. Part Two presents data about the survey populations' types of professional growth activities attended during the past three years and, which one of those activities they found most beneficial as reported in section II of the survey. Part Three presents the effectiveness ratings of professional growth activities, using a Likert scale from 1 (least effective) to 5 (most effective) as reported in section III of the survey. Part Four presents cross tabulations between selected demographic categories and the types of 
professional growth activities attended during the past three years as reported in section I and $I I$ of the survey.

Parts Five through Eight of Chapter Four present data from section IV of the survey instrument (see Appendix B). Part Five presents cross tabulations between selected demographic data and the most valuable professional growth activities. Part Six presents data about the written comments provided by the respondents as to why they selected a particular professional growth activity as their first choice. Part Seven presents cross tabulations between selected demographic data and the least valuable professional growth. And part Eight presents data summarizing written comments respondents made to professional music education organizations that provide activities for high school instrumental teachers.

Cross tabulations were run using a Spearman tho test for correlation (significance of $p<.10$ ) on 11 areas of independent ordinal demographic data and 3 areas of independent response data from sections two and four of the survey. A correlation of $p<.10$ is used.

The eleven demographic areas are cross-tabulated with the variety of professional growth activities attended, most valuable professional growth activity and least valuable professional growth activity. These cross tabulations result in the following 33 categories:

1. The number of years as a teacher with the types of professional growth activities attended during the past three years; the most valuable professional growth activities; and the least valuable professional growth activities.

2. The number of years in the current job with the types of professional growth activities attended during the past three years; the most valuable professional growth activities; and the least valuable professional growth activities. 
3. The level of education with the types of professional growth activities attended during the past three years; the most valuable professional growth activities; and the least valuable professional growth activities.

4. The type of California teaching credential with the types of professional growth activities attended during the past three years; the most valuable professional growth activities; and the least valuable professional growth activities.

5. The amount of district reimbursement with the types of professional growth activities attended during the past three years; the most valuable professional growth activities; and the least valuable professional growth activities.

6. The number of music teachers in the district with the types of professional growth activities attended during the past three years; the most valuable professional growth activities; and the least valuable professional growth activities.

7. The total school enrollment with the types of professional growth activities attended during the past three years; the most valuable professional growth activities; and the least valuable professional growth activities.

8. The school location with the types of professional growth activities attended during the past three years; the most valuable professional growth activities; and the least valuable professional growth activities.

9. The number of students in the instrumental music program with the types of professional growth activities attended during the past three years; the most valuable professional growth activities; and the least valuable professional growth activities.

10. The sex of the respondents with the types of professional growth activities attended during the past three years; the most valuable professional growth activities; and the least valuable professional growth activities. 
11. The race of the respondents with the types of professional growth activities attended during the past three years; the most valuable professional growth activities; and the least valuable professional growth activities.

These demographic categories were chosen because they represent major distinctions within the survey population. Cross tabulations were analyzed in order to discover differences between respondents participation and satisfaction levels in specific professional growth activities and to determine any significant differences among any of the sub-groups.

If the data in any of the sub-groups differ significantly as a result of the Spearman rho test (which shows the probability that there is a variation among one or more of the subgroups within the professional growth activity) then further analysis was performed. Additional analysis determined the extent to which the expected number of responses fell above or below the actual number. For example, if an activity has less than .10 in the probability column following the Spearman tho cross tabulations, then a significant difference exists in one of the sub-groups within that activity. Taking the total number of responses from each sub-group and multiplying that number by the total percentage in the activity row results in datum that represents the expected number of responses within each sub-group. The information concerning significant differences for one or more sub-groups is expressed in percentages in the data analysis in each table.

\section{Terminology}

In this study, the following terms are used in the following ways. The word category and categories refers to demographic information taken from section I of the survey. For example in Table 23, and all cross-tabulation tables, the demographic categories are listed in the table heading such as Number of Years Teaching. Below the heading are the sub- 
categories. Sub-categories refer to the smaller sections within the demographic data such as $0-2$ years and $3-5$ years teaching.

The words activity and activities refer to the items found in the first column of the cross-tabulation tables. These words in the first column identify the various professional growth pursuits.

When the numbers from the activities are cross-tabulated with the numbers from the sub-categories this results in data called sub-groups. An example of sub-group data is the number 33 found in the Attendance at Concert activity row and 0-2 years column in Table 23. Groupings refer to combinations of sub-group data within each activity such as the data from more than one sub-category within an activity. An example would be the numbers found in Attendance at Concerts activity row and 0-2 years combined with the numbers in the 6-10 years teaching column.

\section{Summary}

This chapter described the methods used to collect and analyze data in order to complete the study. It also discussed the individual sections and the purpose of those sections used in the survey instrument. Additional information presented in this chapter included a description of the population surveyed in this study, the cross-tabulations, and the six research questions that were answered through analysis of the data collected by the survey. Tables containing all of the cross-tabulations begin on page 72 with Table 23 . The analysis of these data is provided in Chapter IV. 


\section{FINDINGS}

The data analysis reported in this chapter is a response to the research questions articulated in Chapter One. This study examined the professional growth habits and needs of high school instrumental music teachers of California, and the effectiveness of current professional growth opportunities as perceived by those high school instrumental music teachers. In addition, this study examined the implications of professional growth opportunities for high school instrumental music teachers and the state music organizations that serve them. This investigation concentrated on the following research questions.

1. What types of professional growth activities are high school instrumental music teachers attending in order to satisfy the 150 -hour state requirement needed to maintain the Professional Clear Single Subject Music Credential every five years?

2. What professional growth activities do high school instrumental music teachers find effective in meeting their professional growth needs, and what activities do they find ineffective?

3. To what extent do high school instrumental music teachers participate in nontraditional professional growth activities such as peer mentoring and music education research?

4. Is there a difference in professional growth activities and needs among high school instrumental music teachers who work in urban, rural, and suburban areas of the state? 
5. What are the implications of this study for the state music organizations such as the Southern California School Band and Orchestra Association (SCSBOA), the California Band Directors Association (CDBA), and the California Music Educators Association CMEA?

6. What are the implications for school district leaders such as principals, district administrators, and curriculum coordinators with regard to providing staff development opportunities for the high school instrumental music teachers?

Data analyses and discussion of the findings of the survey (see Appendix B) are presented in eight parts. Part One of this chapter presents the demographic data accumulated through responses provided by the respondents from section I of the survey. Part Two presents data about the survey populations' types of professional growth activities attended during the past three years and, which one of those activities they found benefited them the most as reported in section $I I$ of the survey. Part Three presents the effectiveness ratings of professional growth activities, using a Likert scale from 1 (least effective) to 5 (most effective) as reported in section III of the survey. Part Four presents cross tabulations between selected demographic categories and the types of professional growth activities attended during the past three years as reported in section I and II of the survey.

Parts Five through Eight of Chapter Four present data from section IV of the survey instrument (see Appendix B). Part Five presents cross tabulations between selected demographic data and the most valuable professional growth activities. Part Six presents data about the written comments provided by the respondents as to why they chose a particular professional growth activity as their number one. Part Seven presents cross tabulations between selected demographic data and the least valuable professional growth. Finally, part Eight presents data about the written comments provided by the respondents made to the 
professional music organizations that provide activities for high school instrumental teachers.

See Table 1 for return rates of the survey population.

\section{Part One: Demographics of the Subject Population}

The largest population in the survey is high school instrumental music teachers that have been a high school instrumental music teacher at least 15 years $(39.3 \%)$ while the smallest sub-group is teachers who have 3 to 5 years of experience as a high school instrumental teacher $(12.8 \%)$. Data distribution among the sub-groups is not even nor does it indicate any pattern but $50 \%$ of the teachers have 11 or more years of experience (see Table 2). The next smallest sub-group falls in the 11 to 14 years of teaching experience $(13.23 \%)$ activity followed by teachers with two years or less $(15.7 \%)$.

Table 2

Number of Years as a High School Instrumental Music Teacher

\begin{tabular}{lcc}
\hline Group & Frequency & Percent \\
\hline 0 to 2 years & 38 & 15.7 \\
3 to 5 years & 31 & 12.8 \\
6 to 10 years & 46 & 19.0 \\
11 to 14 years & 32 & 13.2 \\
15 years or more & 95 & 39.3 \\
Total & 242 & 100.0 \\
\hline
\end{tabular}

According to Table 3, Number of Years in Current Job, teachers appear to change jobs frequently if they have been teaching 10 years or less. The two largest sub-groups are those who have been in their current job either 6 to 10 years $(26.2 \%)$ or have been in their job two 
years or less $(26.0 \%)$. Those teachers who have been in their current position from 11 to 14 years make up the smallest sub-category (10.3\%). The data are not distributed evenly among the five sub-categories but $74.5 \%$ of the respondents have been in their current job 10 years or less.

Table 3

Number of Years in Current Job

\begin{tabular}{lcc}
\hline Group & Frequency & Percent \\
\hline 0 to 2 years & 63 & 26.0 \\
3 to 5 years & 54 & 22.3 \\
6 to 10 years & 61 & 26.2 \\
11 to 14 years & 25 & 10.3 \\
15 years or more & 39 & 16.1 \\
Total & 242 & 100.0 \\
\hline
\end{tabular}

Table 4 illustrates the types of California teaching credentials held by the survey population. The majority of respondents hold either a Professional Clear in Music or a Life Credential (74\%). Those respondents required by law to comply with the 150 hours of professional growth requirement each five years comprise $43.8 \%$ (those who hold Professional Clear Credential) of the survey population. Although teachers who hold a Life Credential in Music (30.2\%) are not subject to the professional growth requirements, their responses are included in this study since this study seeks all opinions about professional growth habits and perceptions. A large portion of the respondents (23.9\%) have credentials that are other than Professional Clear Credentials and these teachers are required to 
complete both certification requirements and then professional growth requirements. This grouping includes those who have emergency permits, intern, and preliminary credentials.

A very small portion of the survey population (2.1\%) held supplementary credentials in music and one respondent did not know the type of credential held.

Table 4

Types of California Teaching Credentials

\begin{tabular}{lcc}
\hline Credential & Frequency & Percent \\
\hline Professional Clear in Music & 106 & 43.8 \\
Life in Music & 73 & 30.2 \\
Preliminary Single Subject in Music & 38 & 15.7 \\
Emergency Permits & 17 & 7.0 \\
Other Supplemental in Music & 5 & 2.1 \\
Intern Credential & 2 & 0.8 \\
No Response & 1 & 0.4 \\
Total & 242 & 100.0 \\
\hline
\end{tabular}


Table 5

Highest Degree Earned

\begin{tabular}{lcc}
\hline Degree & Frequency & Percent \\
\hline Bachelors in Music or Music Education & 129 & 53.3 \\
Masters in Music or Music Education & 74 & 30.6 \\
Other Masters & 25 & 10.3 \\
Other Bachelors & 9 & 3.7 \\
Other Doctorate & 3 & 1.2 \\
Doctorate in Music or Music Education & 2 & 0.8 \\
Total & 242 & 100.0 \\
\hline
\end{tabular}

More than half of the respondents $(53.3 \%)$ have earned a Bachelor in Music or Music Education degree (see Table 5). Many of the respondents hold a Master in Music or Music Education (30.6\%).

Tables 6 through 9 indicate levels of yearly financial reimbursement provided by the district to the respondents; their school location in terms of rural, suburban, or urban areas; the number of music teachers at each site; and the number of music teachers in their district.

According to the survey population, $32.2 \%$ receive no financial support from their district for professional growth expenses. On the other hand, $51 \%$ receive some reimbursement but less than $\$ 400$ (see Table 6). A small percentage (4.1\%) received between $\$ 500$ and $\$ 90(0$ and a surprising amount $(9.5 \%)$ were reimbursed for their entire professional growth expenses. Some respondents $(3.3 \%)$ did not indicate how much they were reimbursed. 
Table 6

District Reimbursement for Professional Growth Activities

\begin{tabular}{lcc}
\hline Group & Frequency & Percent \\
\hline No reimbursement & 78 & 32.2 \\
Less than $\$ 200$ & 62 & 25.6 \\
$\$ 200$ to $\$ 400$ & 61 & 25.2 \\
$\$ 500$ to $\$ 900$ & 10 & 4.1 \\
All expenses & 23 & 9.5 \\
No response & 8 & 3.3 \\
Total & 242 & 100.0 \\
\hline
\end{tabular}

Table 7 indicates that nearly half of the respondent's schools are located in suburban areas $(48.3 \%)$ while the rest of the schools are almost equally divided between urban and rural locations ( $28.5 \%$ and $23.1 \%$ respectively).

Table 7

School Location

\begin{tabular}{lcc}
\hline Group & Frequency & Percent \\
\hline Suburban & 117 & 48.3 \\
Urban/Inner City & 69 & 28.5 \\
Rural & 56 & 23.1 \\
Total & 242 & 100.0 \\
\hline
\end{tabular}

The survey asked how many music teachers taught at each school site and the largest response $(46.7 \%)$ were from those whose schools that have two teachers. Table 8 shows that 
$29.3 \%$ of the schools have only one music teacher while $16.1 \%$ have three. A small percentage of schools $(7.9 \%)$ have four or more music teachers.

Table 8

Number of Music Teachers at Each School Site

\begin{tabular}{lcc}
\hline Group & Frequency & Percent \\
\hline One & 71 & 29.3 \\
Two & 113 & 46.7 \\
Three & 39 & 16.1 \\
Four or more & 19 & 7.9 \\
Total & 242 & 100.0 \\
\hline
\end{tabular}

The survey requested data from the respondents to indicate how many high school music teachers were in the respondent's district. Table 9 indicates nearly $70 \%$ of the school districts employed fewer than 10 music teachers per district. Districts with only one music teacher accounted for $19.8 \%$ of the responses while $14.5 \%$ had 10 or more music teachers in their district.

A very small percentage of the respondents $(1.7 \%)$ did not know how many high school music teachers taught in their district. 
Table 9

Number of Music High School Instrumental Teachers in Each District

\begin{tabular}{lcc}
\hline Group & Frequency & Percent \\
\hline One & 48 & 19.8 \\
Two to Four & 62 & 25.6 \\
Five to Nine & 58 & 24.0 \\
Ten to Nineteen & 35 & 14.5 \\
20 or more & 35 & 14.5 \\
Unknown & 4 & 1.7 \\
Total & 242 & 100.0 \\
\hline
\end{tabular}

Tables 10 and 11 present the number of music coordinators or music supervisors that respondents indicated existed and whether or not these supervisors provided professional growth activities for their teachers. If there were no music supervisors, then Table 12 indicates the number of teachers that have combined music supervisor type duties and teaching responsibilities.

Only $35.1 \%$ of the respondents indicated they were supervised by a music administrator compared to $64.9 \%$ that had no music supervision (see Table 10 ).

Of those who did have music supervision $41.1 \%$ said that their music supervisors provided some type of professional growth opportunity for them, while $58.9 \%$ received no professional growth from their supervisor (see Table 11). 
Table 10

Number of Music Coordinators/Supervisors

\begin{tabular}{lcc}
\hline Group & Frequency & Percent \\
\hline Yes & 85 & 35.1 \\
None & 157 & 64.9 \\
Total & 242 & 100.0 \\
\hline
\end{tabular}

Table 11

Music Coordinators Who Provided Professional Growth Activities

\begin{tabular}{lcc}
\hline Group & Frequency & Percent \\
\hline Yes & 35 & 41.1 \\
No & 50 & 58.9 \\
Total & 85 & 100.0 \\
\hline
\end{tabular}

Many teachers are responsible for supervising others in addition to their regular teaching assignments. Table 12 indicates that $23.6 \%$ of the respondents acted as a music supervisor and performed regular teaching duties while $62.2 \%$ did not.

Fourteen percent of the respondents did not indicate whether they had any supervisor type duties. 
Table 12

Music Teachers with Combined Music Supervisor and Teaching Duties

\begin{tabular}{lcc}
\hline Group & Frequency & Percent \\
\hline Yes & 57 & 23.6 \\
No & 151 & 62.4 \\
No response & 34 & 14.0 \\
Total & 242 & 100.0 \\
\hline
\end{tabular}

It should be noted that levels of supervisor activities range from little involvement in the music teachers professional growth activities to highly involved - even to the point of being more involved than a full-time music coordinator might be.

Tables 13 and 14 indicate the total school enrollment and instrumental music program enrollment. When indicating the program enrollment the respondents were asked to include all members that participate in their instrumental program. This included non-musician students who were part of the drill team, flag corps, and any auxiliary units.

More than half (51\%) of the respondents' schools had a total enrollment of over 2000 according to Table 13. These were evenly divided between 2000 to 2499 enrollment subcategory (25.2\%) and 2500 or more enrollment sub-category (25.2\%). The next largest subcategory was enrollments from 1500 to 1999 with $21.9 \%$ followed by $7.4 \%$ indicating enrollments of 500 to 999 . Smaller schools with enrollments of less than 500 students made up only $6.6 \%$ of the survey population. One person did not indicate a school enrollment. 
Table 13

Total School Enrollment

\begin{tabular}{lcc}
\hline Group & Frequency & Percent \\
\hline Fewer than 499 & 16 & 6.6 \\
500 to 999 & 18 & 7.4 \\
1000 to 1499 & 31 & 12.8 \\
1500 to 1999 & 53 & 21.9 \\
2000 to 2499 & 62 & 25.6 \\
2500 or more & 61 & 25.2 \\
No response & 1 & 0.4 \\
Total & 242 & 100.0 \\
\hline
\end{tabular}

Student enrollments in the respondent's instrumental music programs were evenly divided among all five groups. The smallest category was programs with $175-224$ students. Table 14 shows that programs with enrollments of fewer than 75 students made up $23.6 \%$ of the respondent's schools while $24.4 \%$ indicated that they had programs with 76 to 124 students. Programs with 125 to 174 students accounted for $22.3 \%$.

While the first three groups accounted for more than $70 \%$ of the respondent's programs, the larger enrollments accounted for less than $30 \%$ divided between those with 175 to 224 students $(13.2 \%)$ and programs with more than 225 students (16.5\%). 
Table 14

Total Instrumental Program Enrollinent

\begin{tabular}{lcc}
\hline Group & Frequency & Percent \\
\hline Fewer than 75 & 57 & 23.6 \\
76 to 124 & 59 & 24.4 \\
125 to 174 & 54 & 22.3 \\
175 to 224 & 32 & 13.2 \\
225 or more & 40 & 16.5 \\
Total & 242 & 100.0 \\
\hline
\end{tabular}

Table 15 indicates the respondents' memberships in music education organizations. The percentages reflect the ratio of the respondents relative to the total number of respondents. Many respondents belong to more than one music education organization.

There are 46 different music education organizations indicated in Table 15, with the largest membership in the Music Educators National Conference (72.3\%). More than half (56.6\%) of the respondents belong to the Southern California School Band and Orchestra Association and $52.9 \%$ belong to the California Band Directors Association, a group primarily of northern California high school instrumental music teachers. Membership in the International Association of Jazz Educators account for $21.4 \%$ of the survey population while $11.6 \%$ belong to the American String Teachers Association. The California Orchestra Directors Association was the only other music education organization that claimed more than ten percent membership. These six organizations comprised the majority of respondent's membership, while 40 other organizations were represented at less than $6.6 \%$ each. 
The total membership count indicates that the survey population belongs to more than one music education organization and probably belongs to more than two organizations because the average number of memberships per respondent is 2.7 .

Table 15

Membership in Music Education Organizations

\begin{tabular}{|c|c|c|c|}
\hline \multicolumn{2}{|c|}{ Organization } & \multirow{2}{*}{$\frac{\text { Frequency }}{175}$} & \multirow{2}{*}{$\begin{array}{c}\text { Percent } \\
72.3\end{array}$} \\
\hline 1. & Music Educators National Conference & & \\
\hline 2. & Southern California School Band and Orchestra Association & 137 & 56.6 \\
\hline 3. & California Band Directors Association & 128 & 52.9 \\
\hline 4. & International Association of Jazz Educators & 52 & 21.4 \\
\hline 5. & American String Teachers Association & 28 & 11.6 \\
\hline 6. & California Orchestra Directors Association & 25 & 10.0 \\
\hline 7. & Northern California Band Association & 16 & 6.6 \\
\hline 8. & Percussive Arts Society & 10 & 4.1 \\
\hline 9. & World Association for Symphonic Bands and Ensembles & 6 & 2.4 \\
\hline 10. & American Choral Directors Association & 5 & 2.0 \\
\hline 11. & Fresno-Madera County Music Educators Association & 5 & 2.0 \\
\hline 12. & National Bandmasters Association & 5 & 2.0 \\
\hline 13. & American School Band Directors Association & 4 & 1.6 \\
\hline 14. & Southern California Vocal Association & 4 & 1.6 \\
\hline 15. & Western Scholastic Marching Band Conference & 4 & 1.6 \\
\hline & San Bernardino County Music Educators Association & 3 & 1.2 \\
\hline 17. & College Band Directors National Association & 2 & 0.8 \\
\hline
\end{tabular}




\section{Organization}

18. College Music Society

19. Kern County Music Educators Association

20. San Joaquin County Music Educators Association

21. Santa Clara Band Directors Association

22. Stanislaus County Music Educators Association

23. Tulare-Kings County Music Educators Association

24. Winter Guard International

25. Women's Band Directors International

26. American Bandmasters Association

27. American Drum Line Association

28. Dalcroze Association

29. Imperial Valley Music Educators Association

30. International Trombone Association

31. Iowa Bandmasters Association

32. Los Angeles Music Teachers Association

33. Merced-Mariposa County Music Educators Association

34. Missouri Music Educators Association

35. Music Society of the Eastern Sierra

36. North American Brass Band Association

37. Orff Association

38. Pacific Coast Judges Association

39. Southern California Judging Association
Frequency Percent

2

0.8

2

0.8

2

0.8

2

0.8

2

0.8

2

0.8

2

0.8

2

0.8

1

0.4

1

0.4

1

0.4

1

0.4

1

0.4

1

0.4

1

0.4

1

0.4

1

0.4

1

0.4

1

0.4

1

0.4

1

0.4

1

0.4 


\begin{tabular}{lcc}
\hline Organization & Frequency & Percent \\
\hline 40. Suzuki Association of the America & 1 & 0.4 \\
41. Suzuki Music Association of California & 1 & 0.4 \\
42. Texas Bandmasters Association & 1 & 0.4 \\
43. Texas Music Educators Association & 1 & 0.4 \\
44. Tubists Universal Brotherhood Association & 1 & 0.4 \\
45. Washington Music Educators Association & 1 & 0.4 \\
46. Women Band Directors National Association & 1 & 0.4 \\
Total & 646 & \\
\hline
\end{tabular}

In addition to music education organizations, the respondents also were asked to indicate to what other professional organizations they belong. Table 16 lists those organizations, with the teachers unions comprising the largest membership at $21 \%$.

No other organization had more than ten percent. The musicians union included $9 \%$ of the respondents. Every other organization was mentioned by fewer than $2 \%$ of the survey respondents.

Table 16

Other Professional Organizations

\begin{tabular}{lcc}
\hline Group & Frequency & Percent \\
\hline 1. California Teachers Association & 51 & 21.0 \\
2. American Federation of Musicians & 22 & 9.0 \\
3. International Trumpet Guild & 3 & 1.2 \\
4. Rotary/Kiwanis & 3 & 1.2
\end{tabular}




\section{Group}

5. Composers Guild

6. National Association of Music Merchants

7. Alameda Education Foundation

8. American Guild of Organists

9. American Society of Composers Authors \& Publishers

10. American Symphony Orchestra League

11. California Association of Drill Team Instructors

12. California Faculty Association

13. Fresno Dixieland Society

14. Guild of Hand Bell Ringers

15. HTML Writers Guild

16. Martin Luther King Advisory Board

17. Massachusetts Instrumental Conductors Association

18. Pacific Composers Forum

19. Professional Ski Instructors of America

20. Screen Actors Guild

Total
Frequency Percent

2

0.8

2

0.8

1

0.4

1

0.4

1

0.4

1

0.4

1

0.4

1

0.4

1

0.4

1

0.4

1

0.4

1

0.4

1

0.4

1

0.4

1

0.4

1

0.4

97

Collaborations with county organizations and universities and colleges provide opportunities for professional growth activities. Table 17 lists the number of respondents that participated in such collaborations. The percentages are relative to the total number of respondents as they possibly could have participated in more than one activity. 
Table 17

Collaborations with Universities/Colleges and Other Organizations

\begin{tabular}{lcc}
\hline Group & Frequency & Percent \\
\hline With university and/or colleges & 38 & 15.7 \\
With The California Arts Project & 15 & 6.2 \\
With the IMPACT program in San Diego County & 10 & 4.1 \\
Other collaborations & 16 & 6.6 \\
Total & 79 & 100.0 \\
\hline
\end{tabular}

The final demographic categories are sex and race. Table 18 shows that males made up $81.4 \%$ of the respondents, with females comprising only $17.4 \%$. Three respondents did not choose any sub-category for a $1.2 \%$ no response rate.

Table 19 illustrates that the high school instrumental music teachers were $61.6 \%$ Caucasian and $9.9 \%$ Non-Caucasian. Respondents who did not indicate either race comprised $28.5 \%$ of the total survey population.

Table 18

$\underline{\text { Sex }}$

\begin{tabular}{lcc}
\hline Group & Frequency & Percent \\
\hline Male & 197 & 81.4 \\
Female & 42 & 17.4 \\
No response & 3 & 1.2 \\
Total & 242 & 100.0 \\
\hline
\end{tabular}


Table 19

Race

\begin{tabular}{lcc}
\hline Group & Frequency & Percent \\
\hline Caucasian & 149 & 61.6 \\
Non-Caucasian & 24 & 9.9 \\
No response & 69 & 28.5 \\
Total & 242 & 100.0 \\
\hline
\end{tabular}

Demographic Summary

Taking all of the personal demographic information obtained from the survey population, a picture emerges that somewhat shapes the outline of a typical high school instrumental music teacher. This teacher is a male Caucasian with at least 11 years of music teaching experience with less than 10 years in their current job. This teacher has earned a bachelor in music and holds a Professional Clear Single Subject Teaching Credential. This teacher has no music supervisor and receives less than $\$ 200$ for professional growth. This teacher teaches in a suburban school with over 2,000 students along with one other music teacher, with fewer than 9 other music teachers in their district. Their music program involves between 75 and 175 students.

The typical respondent belongs to almost three different music education organizations and has attended 9 different professional growth activities over a three-year period. 


\section{$\underline{\text { Part Two: Types of Professional Growth Activities Attended }}$}

Section II of the survey instrument presented a list of possible professional growth activities and asked the survey population to indicate which events they had attended during the past three years.

Table 20 lists the various professional growth activities attended by the respondents during the past three years. This table includes both the preselected activities given by this researcher and any additional ones indicated by the respondent. The percentages are relative to the total number of respondents $(\mathrm{N}=242)$ as many respondents have attended more than one activity.

Four activities stand out as having participation rates of over $70 \%$. These activities were, in descending order, Attendance at Concerts (92.1\%), Attendance at Music Conferences (88.0\%), Observing Other Rehearsals (78.9\%), and Hosting a Guest Teacher or Clinician (71.1\%). All of these activities are music related activities.

Many teachers attended additional activities but not on the level of the previous four subcategories. This second-tier grouping included activities such as Attendance at On-Campus Inservice (58.3\%), Music Workshops and Non-Music Workshops (57.9\%), New Music Reading Sessions (57.4\%), Being a Guest Teacher or Clinician (57.0\%), and Attendance at Curriculum Development Meeting (51.7\%). All but one of these activities are directly related to music education.

Attendance in the remaining sub-categories falls off significantly to the lowest participation levels of $10 \%$ or less. These sub-categories included participation in County Office of Education Workshops (10.7\%), Beginning Teacher Support \& Assessment (9.9\%), and Online or Distance Learning (7.9\%). None of these lowest ranked activities is directly related to music. 
The additional activities indicated in Table 20 are those written in by the respondents on the survey and thus comprise the smallest levels of participation.

Table 20

Professional Growth Activities Attended by Respondents

\begin{tabular}{|c|c|c|}
\hline Activity & Frequency & Percent \\
\hline Attendance at Concerts & 223 & 92.1 \\
\hline Music Conferences & 213 & 88.0 \\
\hline Observing Other Rehearsals & 191 & $78.9 \%$ \\
\hline Hosting a Guest Teacher or Clinician & 172 & $71.1 \%$ \\
\hline On-Campus Inservice & 141 & $58.3 \%$ \\
\hline Music Workshops & 140 & $57.9 \%$ \\
\hline Non-Music Workshops & 140 & $57.9 \%$ \\
\hline New Music Reading Sessions & 139 & $57.4 \%$ \\
\hline Being a Guest Teacher or Clinician & 138 & $57.0 \%$ \\
\hline Curriculum Development Meetings & 125 & $51.7 \%$ \\
\hline Additional College/University Coursework & 111 & $45.9 \%$ \\
\hline Service in a Music Organization & 86 & $35.5 \%$ \\
\hline District Sponsored Workshops & 85 & $35.1 \%$ \\
\hline Peer Mentoring Activities & 59 & $24.4 \%$ \\
\hline Non-music conference & 51 & $21.1 \%$ \\
\hline Service as a Mentor Teacher & 48 & $19.8 \%$ \\
\hline Educational Research & 45 & $18.6 \%$ \\
\hline County Office of Education Workshops & 26 & $10.7 \%$ \\
\hline
\end{tabular}




\begin{tabular}{lcc}
\hline Activity & Frequency & Percent \\
\hline Beginning Teacher Support \& Assessment Program & 24 & $09.9 \%$ \\
Online or Distance Learning & 19 & $07.9 \%$ \\
Performing as a Musician & 7 & $02.8 \%$ \\
Concert Festival Participation & 2 & $00.8 \%$ \\
Conducting Honor Groups & 2 & $00.8 \%$ \\
Clinics with University Ensembles & 1 & $00.4 \%$ \\
Serving on Education Committees & 1 & $00.4 \%$ \\
The California Arts Project & 1 & $00.4 \%$ \\
\hline
\end{tabular}

Fifteen respondents indicated (Table 17) that they had participated as collaborators in The California Arts Project. Yet, when asked to indicate all professional growth activities in section II of the survey, only one of those sixteen indicated their participation (Table 20). This discrepancy may be due to the respondent's view that participation in the California Arts Project falls under Additional College/University Coursework activity.

While a number of activities were attended by more than $50 \%$ of the respondents, Table 21 indicates that only a few of these activities were selected as having specifically benefited them. The most beneficial activity by far is attendance at Music Conferences as chosen by $38.4 \%$ of the respondents. Only three other activities were selected at a rate greater than 10\%. These were Hosting a Guest Teacher or Clinician (19.8\%), Observing Other Rehearsals (17.7\%), and Attendance at Music Workshops (11.5\%).

The remaining activities were selected once or not at all. Seventeen activities were chosen with at least one vote for most effective activity, and four activities were left blank. Percentages for this group of activities ranged from a high of $8.6 \%$ for Taking Additional 
College/University Coursework to a low of .4\% for attendance at the California Arts

Project.

The four activities without any selections were County Office of Education Workshops, Non-Music Conferences, On-Campus In-Service, and Service as a Mentor Teacher.

Table 21

Activities that Provided the Most Benefit

\begin{tabular}{|c|c|c|}
\hline Activity & Frequency & Percent \\
\hline Music Conferences & 93 & $38.4 \%$ \\
\hline Hosting a Guest Teacher or Clinician & 48 & $19.8 \%$ \\
\hline Observing Other Rehearsals & 43 & $17.7 \%$ \\
\hline Music Workshops & 28 & $11.5 \%$ \\
\hline Additional College/University Coursework & 21 & $08.6 \%$ \\
\hline Attending Concerts & 14 & $05.7 \%$ \\
\hline Being a Guest Teacher or Clinician & 12 & $04.9 \%$ \\
\hline New Music Reading Sessions & 12 & $04.9 \%$ \\
\hline Service in a Music Organization & 10 & $04.1 \%$ \\
\hline Performing as a Musician & 7 & $02.8 \%$ \\
\hline Curriculum Development Meetings & 5 & $02.0 \%$ \\
\hline Peer Mentoring Activities & 5 & $02.0 \%$ \\
\hline Conducting Honor Groups & 2 & $00.8 \%$ \\
\hline Educational Research & 2 & $00.8 \%$ \\
\hline Festival participation & 2 & $00.8 \%$ \\
\hline Non-Music Workshops & 2 & $00.8 \%$ \\
\hline
\end{tabular}




\begin{tabular}{lcc}
\hline Activity & Frequency & Percent \\
\hline Online or Distance Learning & 2 & $00.8 \%$ \\
Beginning Teacher Support and Assessment program & 1 & $00.4 \%$ \\
Clinics with University Ensembles & 1 & $00.4 \%$ \\
Serving on Educational Committees & 1 & $00.4 \%$ \\
The California Arts Project & 1 & $00.4 \%$ \\
County Office of Education Workshops & 0 & $00.0 \%$ \\
Non-Music Conferences & 0 & $00.0 \%$ \\
On-Campus Inservice & 0 & $00.0 \%$ \\
Service as a Mentor Teacher & 0 & $00.0 \%$ \\
\hline
\end{tabular}

\section{Part Three: Effectiveness Rating of Professional Growth Activities}

Table 22 illustrates, in rank descending order, the mean scores of the effectiveness of the listed professional growth activities of the respondents. The mean is derived from a fivepoint Likert scale ranging from least effective (1) to most effective (5). (See Appendix B, Section III). The mode indicates which scale number was chosen most often in each activity. Additional data reported are the number of responses each activity received, the standard error, and standard deviation.

Three activities were chosen by more than $85 \%$ of the survey population with corresponding mean scores greater than 4.00 , indicating that these activities were identified as being somewhat effective by a significant majority of the respondents. These were Attendance at Concerts (94/2\%), Music Conferences (88.8\%), and Observing Other Rehearsals (85.1\%).

One activity from Table 22 with a significant response rate had a higher mode and mean score. Having a Guest Clinician or Teacher earned the highest mean from the largest amount 
of respondents $(\mathrm{N}=181)$ with a low standard error $\left(5.16^{\mathrm{E}-03}\right)$ and low standard deviation (0.69). This activity was identified by the respondents as being the most effective.

One activity scored a high mean rating but it only had 13 respondents. This activity was identified as "Other" (4.77). The Other activity included respondents" listings of professional growth activities that were not previously listed such as (a) conducting honor bands, (b) participating in festivals, (c) performing in ensembles as musicians rather than as directors or conductors, (d) participating in The California Arts Project, (e) serving on district-wide education committees, and ( $f$ ) sharing clinic rehearsals with college bands.

The survey population identified eight activities as being average in effectiveness. Five of those activities had a standard deviation larger than 1.00 indicating that many respondents found these activities somewbat ineffective and other respondents found them somewhat effective. These five activities included Additional University/College Coursework (3.80 1.03 ), Service in a Music Organization (3.65 \pm 1.12 ), Peer Mentoring Activities (3.37 \pm 1.10 ),

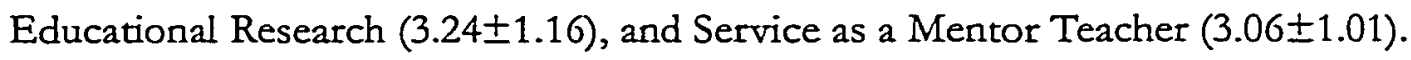

Table 22 also indicates that the survey respondents identified six activities as being somewhat ineffective. Five of these activities had standard deviations larger than 1.0 and all of these activities' modes were either very ineffective or somewhat ineffective. The activities identified as being somewhat ineffective were Curriculum Development Meetings (2.53 \pm 1.05 ),

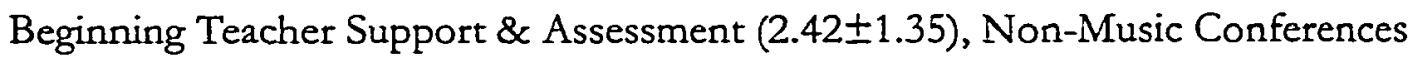

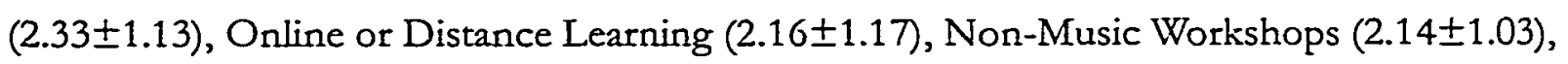

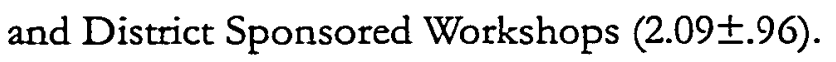

Finally, two activities had mean scores of less than 2.00 and standard deviations of less than 1.00. The survey respondents identified County Office of Education Workshops 


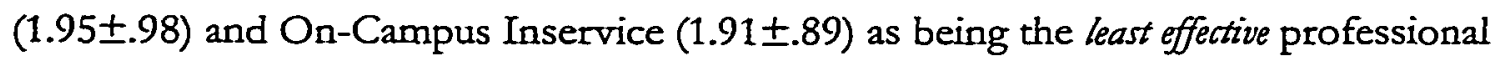
growth activities.

Table 22

Mean Score Showing Perceived Effectiveness and Ineffectiveness of Professional Growth Activities.

\begin{tabular}{|c|c|c|c|c|c|}
\hline Activity & $N$ & Mean & $\begin{array}{l}\text { Standard. } \\
\text { Error }\end{array}$ & $\begin{array}{l}\text { Standard } \\
\text { Deviation }\end{array}$ & Mode \\
\hline Other & 13 & 4.77 & 0.12 & 0.44 & 5 \\
\hline Having a Guest Clinician or Teacher & 181 & 4.45 & $5.16^{\mathrm{E}-03}$ & 0.69 & 5 \\
\hline Observing Other Rehearsals & 206 & 4.29 & $4.96^{E-03}$ & 0.71 & 4 \\
\hline Music Conferences & 215 & 4.02 & $6.08^{E-03}$ & 0.89 & 4 \\
\hline Attendance at Concerts & 228 & 4.02 & $5.01^{\mathrm{E}-03}$ & 0.76 & 4 \\
\hline Music Workshops & 168 & 3.95 & $6.14^{\mathrm{E}-03}$ & 0.80 & 4 \\
\hline Being a Guest Teacher or Clinician & 132 & 3.82 & $8.25^{\mathrm{E}-03}$ & 0.95 & 4 \\
\hline Additional Univ./College Coursework & 138 & 3.80 & $8.78^{\mathrm{E}-03}$ & 1.03 & 4 \\
\hline New Music Reading Sessions & 155 & 3.77 & $7.37^{\mathrm{E}-03}$ & 0.92 & 4 \\
\hline Service in a Music Organization & 130 & 3.65 & $9.81^{E-03}$ & 1.12 & 4 \\
\hline Peer Mentoring Activities & 83 & 3.37 & 0.12 & 1.10 & 3 \\
\hline Educational Research & 78 & 3.24 & 0.13 & 1.16 & 4 \\
\hline Service as a Mentor Teacher & 72 & 3.06 & 0.12 & 1.01 & 3 \\
\hline Curriculum Development Meetings & 148 & 2.53 & $8.60^{\mathrm{E}-03}$ & 1.05 & 2 \\
\hline Beginning Teacher Support \& Assessment & 48 & 2.42 & 0.19 & 1.35 & 1 \\
\hline Non-Music Conferences & 135 & 2.33 & $9.74^{E-03}$ & 1.13 & 2 \\
\hline Online or Distance Learning & 51 & 2.16 & 0.16 & 1.17 & 1 \\
\hline Non-Music Workshops & 134 & 2.14 & $8.87^{E-03}$ & 1.03 & 1 \\
\hline
\end{tabular}




\begin{tabular}{lrcccc}
\hline Activity & N & Mean & $\begin{array}{c}\text { Standard. } \\
\text { Error }\end{array}$ & $\begin{array}{c}\text { Standard } \\
\text { Deviation }\end{array}$ & Mode \\
\hline District Sponsored Workshops & 137 & 2.09 & $8.22^{\mathrm{E}-03}$ & 0.96 & 2 \\
County Office of Ed. Workshops & 58 & 1.95 & 0.13 & 0.98 & 1 \\
On-Campus Inservice & 173 & 1.91 & $6.75^{\mathrm{E}-03}$ & 0.89 & 2 \\
\hline
\end{tabular}

\section{Part Four: Cross Tabulations Between Types of Professional Growth Activities Attended}

\section{During the Past Three Years and Demographic Categories}

Eleven demographic categories were chosen for cross-tabularion with the professional growth activities found in section II of the survey instrument (Appendix B). These categories represent major distinctions among the respondents such as level of education, teaching experience, and school location. The specific categories are (a) the number of years as a teacher, (b) the number of years in the current job, (c) the level of education, (d) the type of California teaching credential, (e) the amount of district reimbursement, $(f)$ the number of music teachers in the district, $(\mathrm{g})$ the school size, $(\mathrm{h})$ the number of students in the program, (i) the sex of the respondents, (j) the race of the respondents, and (k) the school location. Tables 23 through 33 shows the cross-tabulation data for these eleven demographic categories.

These cross tabulations were analyzed in order to discover differences between respondents participation levels in specific professional growth activities and to determine significant differences among any of the sub-groups.

If the data in any of the sub-groups differ significantly as a result of the Spearman tho test (which shows the probability that there is a variation among one or more of the subgroups within the professional growth activity) then further analysis was performed. 
Additional analysis determined the extent to which the expected number of responses fell above or below the actual number of responses.

For example, if an activity has less than .10 in the probability column following the Spearman rho cross tabulations, then a significant difference exists in one of the sub-groups within that activity. Taking the total number of responses from each sub-group and multiplying that number by the total percentage in the activity row results in datum that represents the expected number of responses within each sub-group. The information concerning significant differences for one or more sub-groups will be expressed in percentages in the analysis of the data in each table.

Each table is organized by listing the activities in descending order based upon the total percentage of responses supplied by the survey population. The total population average level of each activity is indicated in the column with the heading "\% of Total."

In all of the following cross-tabulation tables, the terms "Activity," "Category," "SubCategory," "Sub-Groups," and "Groupings" are used according to the explanations and definitions presented in the Terminology section from Chapter Three of this study (page 43).

Table 23 shows the cross tabulations between the total number of years as a high school instrumental music teacher and types of professional growth activities attended during the past three years. The data indicate that there are eight activities in which the participation levels of the respondents vary significantly $(p<.10)$ from the average according to the number of years teaching.

Teachers with 10 years or less of teaching experience attend Music Conferences, Music Workshops, Serve in a Music Organization, Attend District Sponsored Workshops, and Serve as Mentor Teachers at rates less than the total percentage of the survey population. 
Teachers with 3-5 years of experience attended Music Workshops $6.7 \%$ more often, and teachers with 6-10 years of experience attended District Sponsored Workshops $8.3 \%$ more often than the total population average.

Teachers with 14 years or less took Additional College Coursework and did Educational Research more than the survey population average. The participation average for Additional College Coursework activities was $45.8 \%$. Yet, this sub-group participated up to $13 \%$ more often than the rest of the survey population.

These two activities are used to accumulate units, which can be applied towards advancement on their district salary schedule. This would explain why teachers with 15 years or more of experience participate in this activity less because they probably already have accumulated the maximum necessary units for salary advancement.

Teachers with 15 years or more of teaching experience attend Music Conferences, Music Workshops, Serve in a Music Organization, attend District Sponsored Workshops, and Serve as Mentor Teachers at rates greater than the average of the survey population. This sub-group participates at lower levels than the average in activities such as taking Additional College Coursework (45.8\% vs. $31.5 \%)$ and doing Educational Research (18.5\% vs. $12.6 \%)$.

Beginning Teacher Support and Assessment participation among teachers with 0-2 years of experience was $26.9 \%$ greater than the $9.9 \%$ average of the respondents. 
Table 23

Staff Development Activities Attended by the Number of Years Teaching

\begin{tabular}{|c|c|c|c|c|c|c|c|c|}
\hline \multirow[b]{3}{*}{ Activity } & \multicolumn{5}{|c|}{ Number of Years Teaching } & \multirow[b]{2}{*}{ Total } & \multirow{2}{*}{ 焉 } & \multirow[b]{2}{*}{ Significance } \\
\hline & $0-2$ & $3-5$ & $6-10$ & $11-14$ & $15+$ & & & \\
\hline & $\mathrm{N}=38$ & $N=31$ & $N=46$ & $\mathrm{~N}=32$ & $\mathrm{~N}=95$ & $\mathrm{~N}=242$ & a & $p<.10$ \\
\hline $\begin{array}{l}\text { Attendance at } \\
\text { Concerts }\end{array}$ & 33 & 27 & 44 & 30 & 89 & 223 & $92.1 \%$ & .181 \\
\hline $\begin{array}{l}\text { Music } \\
\text { Conferences }\end{array}$ & 32 & 26 & 38 & 29 & 88 & 213 & $88.0 \%$ & .061 \\
\hline $\begin{array}{l}\text { Observing Other } \\
\text { Rehearsals }\end{array}$ & 32 & 25 & 38 & 26 & 70 & 191 & $78.9 \%$ & .129 \\
\hline $\begin{array}{l}\text { Hosting a Guest } \\
\text { Clinician/Teacher }\end{array}$ & 22 & 20 & 37 & 22 & 71 & 172 & $71.0 \%$ & .104 \\
\hline $\begin{array}{l}\text { Non-Music } \\
\text { Workshops }\end{array}$ & 24 & 16 & 29 & 21 & 50 & 140 & $57.8 \%$ & .350 \\
\hline $\begin{array}{l}\text { On-Campus } \\
\text { Inservice }\end{array}$ & 19 & 19 & 26 & 24 & 53 & 141 & $58.2 \%$ & .756 \\
\hline Music Workshops & 17 & 20 & 25 & 14 & 64 & 140 & $57.8 \%$ & .045 \\
\hline $\begin{array}{l}\text { Being a Guest } \\
\text { Clinician/Teacher }\end{array}$ & 17 & 20 & 26 & 17 & 58 & 138 & $57.0 \%$ & .252 \\
\hline $\begin{array}{l}\text { New Music } \\
\text { Reading Sessions }\end{array}$ & 15 & 14 & 23 & 23 & 64 & 139 & $57.4 \%$ & .000 \\
\hline $\begin{array}{l}\text { Curriculum } \\
\text { Meetings }\end{array}$ & 13 & 17 & 25 & 15 & 55 & 125 & $51.6 \%$ & .057 \\
\hline $\begin{array}{l}\text { Additional } \\
\text { College } \\
\text { Coursework }\end{array}$ & 22 & 18 & 22 & 19 & 30 & 111 & $45.8 \%$ & .001 \\
\hline $\begin{array}{l}\text { Service in a } \\
\text { Music } \\
\text { Organization }\end{array}$ & 9 & 3 & 13 & 11 & 50 & 86 & $35.5 \%$ & .000 \\
\hline $\begin{array}{l}\text { District } \\
\text { Sponsored } \\
\text { Workshops }\end{array}$ & 8 & 8 & 20 & 10 & 39 & 85 & $35.1 \%$ & .039 \\
\hline
\end{tabular}




\begin{tabular}{|c|c|c|c|c|c|c|c|c|}
\hline \multirow[b]{2}{*}{ Activity } & \multicolumn{5}{|c|}{ Number of Years Teaching } & \multirow[b]{2}{*}{$\begin{array}{l}\text { Total } \\
N=242\end{array}$} & \multirow[b]{2}{*}{$\begin{array}{c}\text { 至 } \\
\text { 量 } \\
0 \\
0 \\
0\end{array}$} & \multirow[b]{2}{*}{$\begin{array}{c}\text { Significance } \\
\qquad p<.10\end{array}$} \\
\hline & $\begin{array}{c}0-2 \\
\mathrm{~N}=38\end{array}$ & $\begin{array}{c}3-5 \\
N=31\end{array}$ & $\begin{array}{l}6-10 \\
N=46\end{array}$ & $\begin{array}{l}11-14 \\
N=32\end{array}$ & $\begin{array}{l}15+ \\
N=95\end{array}$ & & & \\
\hline $\begin{array}{l}\text { Peer Mentoring } \\
\text { Activities }\end{array}$ & 11 & 5 & 8 & 10 & 25 & 59 & $24.3 \%$ & .585 \\
\hline $\begin{array}{l}\text { Non-Music } \\
\text { Conferences }\end{array}$ & 7 & 7 & 14 & 5 & 18 & 51 & $21.0 \%$ & .608 \\
\hline $\begin{array}{l}\text { Service as a } \\
\text { Mentor Teacher }\end{array}$ & 1 & 2 & 6 & 6 & 33 & 48 & $19.8 \%$ & .000 \\
\hline $\begin{array}{l}\text { Educational } \\
\text { Research }\end{array}$ & 8 & 9 & 9 & 7 & 12 & 45 & $18.5 \%$ & .072 \\
\hline $\begin{array}{l}\text { County Office of } \\
\text { Ed. Workshops }\end{array}$ & 3 & 3 & 3 & 6 & 11 & 26 & $10.7 \%$ & .401 \\
\hline $\begin{array}{l}\text { Beginning } \\
\text { Teacher Support } \\
\text { \& Assessment }\end{array}$ & 14 & 2 & 3 & 0 & 5 & 24 & $09.9 \%$ & .000 \\
\hline $\begin{array}{l}\text { Online/Distance } \\
\text { Learning }\end{array}$ & 2 & 4 & 3 & 0 & 10 & 19 & $07.8 \%$ & .538 \\
\hline Other ${ }^{a}$ & 2 & 2 & 4 & 2 & 7 & 17 & $07.0 \%$ & .767 \\
\hline
\end{tabular}

a This included activities such as performing as a musician, festival participation, conducting honor groups, clinics with university ensembles, and serving on education committees.

Tables 23 through 33 will use these same designations for the Other activity.

It must be noted that significant differences appear in participation levels in Service as a Mentor Teacher and Beginning Teacher Support and Assessment activities because of the nature of the activities and the fact that these activities are geared toward specific years of teaching experience and should not be considered statistically significant. For example, it is logical that new teachers should not serve as mentor teachers. However, teachers with 0-2 years of experience should participate in Beginning Teacher Support and Assessment 
activities. Further, teachers with 15 years or more of experience should participate in mentor teacher activities at levels greater than the survey population.

Table 24 shows the cross tabulations between the number of years the survey population have been in their most recent employment and the types of professional growth activities attended during the past three years. The data indicate that there are eight activities in which the participation levels of the respondents vary significantly $(p<.10)$ from the average according to the number of years in their current position. These activities include (a) Music Conferences, (b) New Music Reading Sessions, (c) Service as a Mentor Teacher, (d) Non-Music Conferences, (e) Additional College Coursework, ( $f$ ) Service in a Music Organization, (g) Non-Music Workshops, and (h) Beginning Teacher Support and Assessment.

On the average $88 \%$ of the population participated in Music Conferences, $57.4 \%$ participated in New Music Reading Sessions, and 35.5\% provided service to a music organization. Yet teachers with five years or less in their current job participated less than the average while teachers with six or more years in their current job participated more than the average.

In contrast, an average of $21 \%$ of the population participated in Non-Music Conferences, $45.8 \%$ in Additional College Coursework, $57.8 \%$ in Non-Music Workshops, and $9.9 \%$ in Beginning Teacher Support and Assessment. However, teachers with five years or less in their current job participated more than the average and teachers with six or more years in their current job participated less than the average. 
Table 24

Staff Development Activities Attended by Number of Years in Current Job

\begin{tabular}{|c|c|c|c|c|c|c|c|c|}
\hline \multirow[b]{2}{*}{ Activity } & \multicolumn{5}{|c|}{ Number of Years in Current Job } & \multirow[b]{2}{*}{ Total } & \multirow[b]{2}{*}{ 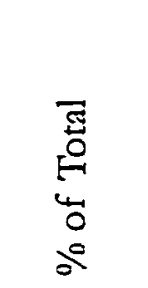 } & \multirow[b]{2}{*}{$\begin{array}{l}\text { Significance } \\
\qquad p<.10\end{array}$} \\
\hline & $\begin{array}{c}0-2 \\
N=63\end{array}$ & $\begin{array}{c}3-5 \\
N=54\end{array}$ & $\begin{array}{l}6-10 \\
N=61\end{array}$ & $\begin{array}{l}11-14 \\
N=25\end{array}$ & $\begin{array}{c}15+ \\
N=39\end{array}$ & & & \\
\hline $\begin{array}{l}\text { Attendance at } \\
\text { Concerts }\end{array}$ & 56 & 51 & 55 & 22 & 39 & 223 & $92.1 \%$ & .218 \\
\hline $\begin{array}{l}\text { Music } \\
\text { Conferences }\end{array}$ & 52 & 44 & 57 & 24 & 36 & 213 & $88.0 \%$ & .018 \\
\hline $\begin{array}{l}\text { Observing Other } \\
\text { Rehearsals }\end{array}$ & 51 & 43 & 46 & 20 & 31 & 191 & $78.9 \%$ & .744 \\
\hline $\begin{array}{l}\text { Hosting a Guest } \\
\text { Clinician/Teacher }\end{array}$ & 40 & 42 & 46 & 17 & 27 & 172 & $71.0 \%$ & .592 \\
\hline $\begin{array}{l}\text { On-Campus } \\
\text { Inservice }\end{array}$ & 37 & 36 & 27 & 16 & 25 & 141 & $58.2 \%$ & .905 \\
\hline Music Workshops & 34 & 33 & 30 & 17 & 26 & 140 & $57.8 \%$ & .295 \\
\hline $\begin{array}{l}\text { Non-Music } \\
\text { Workshops }\end{array}$ & 43 & 34 & 32 & 11 & 20 & 140 & $57.8 \%$ & .016 \\
\hline $\begin{array}{l}\text { New Music } \\
\text { Reading Session }\end{array}$ & 24 & 29 & 40 & 19 & 27 & 139 & $57.4 \%$ & .000 \\
\hline $\begin{array}{l}\text { Being a Guest } \\
\text { Clinician/Teacher }\end{array}$ & 31 & 31 & 41 & 17 & 18 & 138 & $57.0 \%$ & .495 \\
\hline $\begin{array}{l}\text { Curriculum } \\
\text { Meetings }\end{array}$ & 31 & 31 & 24 & 15 & 24 & 125 & $51.6 \%$ & .476 \\
\hline $\begin{array}{l}\text { Additional } \\
\text { College } \\
\text { Coursework }\end{array}$ & 32 & 32 & 26 & 11 & 10 & 111 & $45.8 \%$ & .008 \\
\hline $\begin{array}{l}\text { Service in a } \\
\text { Music } \\
\text { Organization }\end{array}$ & 15 & 17 & 25 & 10 & 19 & 86 & $35.5 \%$ & .005 \\
\hline $\begin{array}{l}\text { District } \\
\text { Sponsored } \\
\text { Workshops }\end{array}$ & 16 & 27 & 22 & 9 & 11 & 85 & $35.1 \%$ & .912 \\
\hline
\end{tabular}




\begin{tabular}{|c|c|c|c|c|c|c|c|c|}
\hline \multirow[b]{3}{*}{ Activity } & \multicolumn{5}{|c|}{ Number of Years in Current Job } & \multirow[b]{2}{*}{ Total } & \multirow{3}{*}{ 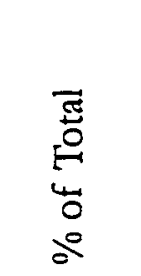 } & \multirow{3}{*}{$\begin{array}{l}\text { Significance } \\
\qquad p<.10\end{array}$} \\
\hline & $0-2$ & $3-5$ & $6-10$ & $11-14$ & $15+$ & & & \\
\hline & $N=63$ & $N=54$ & $N=61$ & $\mathrm{~N}=25$ & $\mathrm{~N}=39$ & $N=242$ & & \\
\hline $\begin{array}{l}\text { Peer Mentoring } \\
\text { Activities }\end{array}$ & 18 & 11 & 12 & 7 & 11 & 59 & $24.3 \%$ & .946 \\
\hline $\begin{array}{l}\text { Non-Music } \\
\text { Conferences }\end{array}$ & 17 & 13 & 12 & 2 & 7 & 51 & $21.0 \%$ & .080 \\
\hline $\begin{array}{l}\text { Service as a } \\
\text { Mentor Teacher }\end{array}$ & 3 & 12 & 11 & 6 & 16 & 48 & $19.8 \%$ & .000 \\
\hline $\begin{array}{l}\text { Educational } \\
\text { Research }\end{array}$ & 11 & 18 & 6 & 5 & 5 & 45 & $18.5 \%$ & .201 \\
\hline $\begin{array}{l}\text { County Office of } \\
\text { Ed. Workshops }\end{array}$ & 5 & 7 & 3 & 4 & 7 & 26 & $10.7 \%$ & .220 \\
\hline $\begin{array}{l}\text { Beginning } \\
\text { Teacher Support } \\
\text { \& Assessment }\end{array}$ & 16 & 4 & 0 & 0 & 4 & 24 & $09.9 \%$ & .000 \\
\hline $\begin{array}{l}\text { Online/Distance } \\
\text { Learning }\end{array}$ & 2 & 7 & 4 & 2 & 4 & 19 & $07.8 \%$ & .375 \\
\hline Other & 4 & 6 & 2 & 0 & 5 & 17 & $07.0 \%$ & .952 \\
\hline
\end{tabular}

There was no pattern to the participation levels in the activity of Service as a Mentor Teacher. The participation rate for all respondents in this activity was $19.8 \%$. Yet teachers with $0-2$ years and $6-10$ years in their current job participated less than the average and teachers with 3-5 years and 11 years or more participated more. Logically teachers who have been in their current job for 15 years or more provide Service as a Mentor Teacher and Table 24 indicates that this sub-group has a participation rate of $41 \%$, which is significantly greater than the $19.8 \%$ average.

Table 25 illustrates cross tabulations between levels of education obtained by the survey population and types of the various professional growth activities attended during the past three years. The data indicate that there are three activities in which the participation levels 
of the respondents vary significantly $(p<.10)$ from the average according to the levels of education. These activities are (a) Music Conferences, (b) Attendance at Concerts, and (c) Additional College Coursework.

The average attendance level of the survey population at Music Conferences is $88 \%$. Yet teachers with both music and non-music bachelor degrees and masters in music attend less often than the average while teachers with other masters attend $12 \%$ more. The participation rate for all respondents in concert attendance is $92.1 \%$ while teachers with bachelors in music attend less often (89\%) and teachers with master's degrees attend more often $(96 \%)$.

Taking additional college or university course is an area where the participation rate for all respondents is $45.8 \%$. Yet, teachers with bachelor's degrees attend slightly more than the average and teachers with advanced degrees attend less than the average.

Table 25

Staff Development Activities Attended by Level of Education

Level of Education

\begin{tabular}{|c|c|c|c|c|c|c|c|c|}
\hline 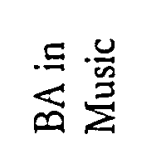 & 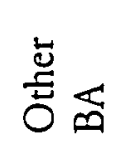 & 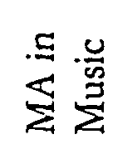 & 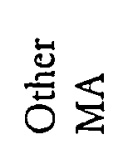 & 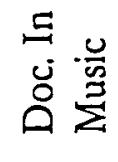 & 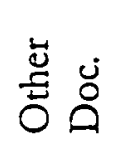 & 哭 & 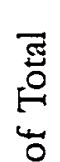 & Sig. \\
\hline$N=129$ & $N=9$ & $N=74$ & $\mathrm{~N}=25$ & $\mathrm{~N}=2$ & $N=3$ & $N=242$ & å & $p<.10$ \\
\hline
\end{tabular}

$\begin{array}{llllllllll}\text { Attendance at } & 115 & 8 & 71 & 24 & 2 & 3 & 223 & 92.1 \% & .053\end{array}$

Concerts

$\begin{array}{llllllllll}\text { Music } & 110 & 8 & 65 & 25 & 2 & 3 & 213 & 88.0 \% & .072\end{array}$

Conferences

$\begin{array}{llllllllll}\text { Observing Other } & 101 & 7 & 54 & 24 & 2 & 3 & 191 & 78.9 \% & .354\end{array}$

Rehearsals

$\begin{array}{llllllllll}\text { Hosting a Guest } & 88 & 5 & 56 & 19 & 1 & 3 & 172 & 71.0 \% & .214\end{array}$

Teacher/Clinician 


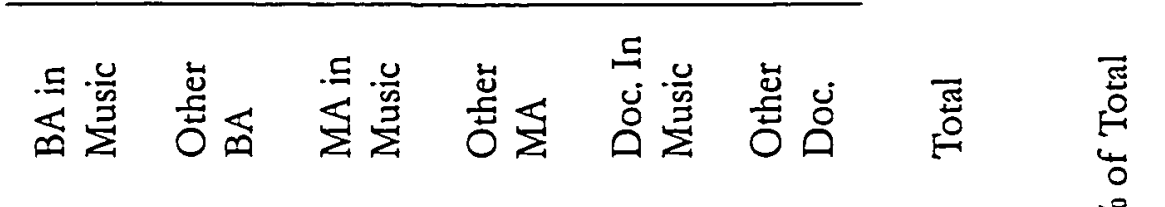

Sig.

Activity

$N=129 \quad N=9 \quad N=74 \quad N=25$

On-Campus

74

$4 \quad 46$

13

$\mathrm{N}=2$

$N=3 \quad N=242$

d

$p<.10$

Inservice

Music Workshops

Non-Music

70

$6 \quad 42$

20

2

141

$58.2 \%$

.725

Workshops

New Music

$\begin{array}{lll}78 & 5 & 44\end{array}$

12

0

2140

$57.8 \%$

.152

Reading Sessions

Being a Guest

Teacher/Clinician

Curriculum

$69 \quad 5$

47

16

0

1

$140 \quad 57.8 \% \quad .213$

Development

Meetings

Additional

College

Coursework

Service in a

Music

70

6

42

18

1

1

$139 \quad 57.4 \% \quad .223$

Organization

District

Sponsored

$\begin{array}{lll}66 & 4 & 38\end{array}$

13

2

2

125

$51.6 \% \quad .698$

Workshcps

Peer Mentoring

Activities

Non-Music

$64 \quad 6$

33

7

0

1

111

$45.8 \% \quad .062$

Conferences

Service as a

Mentor Teacher

45

$2 \quad 29$

$\begin{array}{lll}46 & 3 & 26\end{array}$

8

1

1

$85 \quad 35.1 \% \quad .844$

Educational

Research

County Office of

Ed. Workshops

$\begin{array}{lllllllll}33 & 1 & 19 & 4 & 2 & 0 & 59 & 24.3 \% & .675 \\ 27 & 4 & 12 & 5 & 0 & 3 & 51 & 21.0 \% & .904 \\ 22 & 2 & 17 & 6 & 0 & 1 & 48 & 19.8 \% & .263 \\ 22 & 1 & 16 & 3 & 1 & 2 & 45 & 18.5 \% & .435 \\ 10 & 4 & 7 & 5 & 0 & 0 & 26 & 10.7 \% & .213\end{array}$




\begin{tabular}{|c|c|c|c|c|c|c|c|c|c|}
\hline & 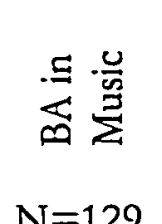 & 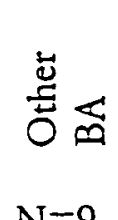 & 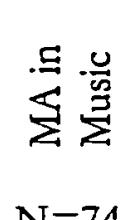 & $\stackrel{\breve{d}}{0} \leftrightarrows$ & 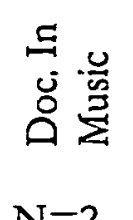 & 莺 & Е & 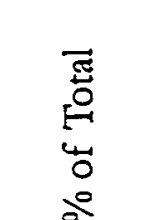 & Sig. \\
\hline Activity & $N=129$ & $N=9$ & $N=74$ & $N=25$ & $\mathrm{~N}=2$ & $N=3$ & $N=242$ & & $p<.10$ \\
\hline $\begin{array}{l}\text { Beginning } \\
\text { Teacher Support } \\
\text { \& Assessment }\end{array}$ & 16 & 3 & 3 & 1 & 1 & 0 & 24 & $09.9 \%$ & .100 \\
\hline $\begin{array}{l}\text { Online/Distance } \\
\text { Learning }\end{array}$ & 13 & 0 & 5 & 0 & 0 & 1 & 19 & $07.8 \%$ & .194 \\
\hline Other & 7 & 3 & 5 & 2 & 0 & 0 & 17 & $07.0 \%$ & .638 \\
\hline
\end{tabular}

Table 26 indicates cross tabulations between type of California teaching credential held by the survey population and variety of professional growth activities attended during the past three years. The data indicate that there are six activities in which the participation levels of the respondents vary significantly $(p<10)$ from the average according to the type of credential. These activities are (a) New Music Reading Sessions, (b) Service as a Mentor Teacher, (c) County Office of Education Workshops, (d) Beginning Teacher Support and Assessment, (e) taking Additional College Coursework, and (f) Service in a Music Organization. 
Table 26

Staff Development Activities Attended by Type California Teaching Credential

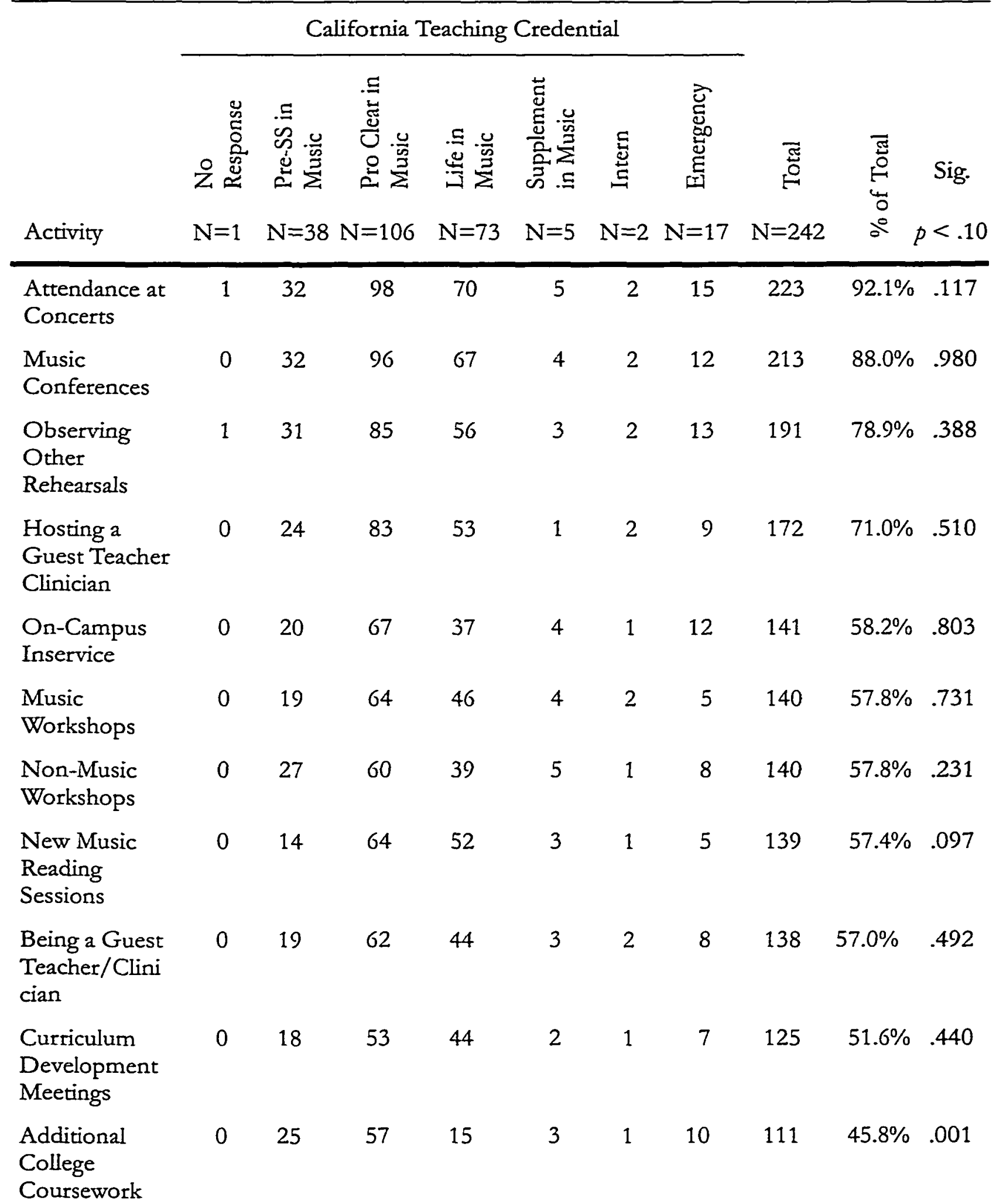




\begin{tabular}{|c|c|c|c|c|c|c|c|c|c|c|}
\hline \multirow[b]{2}{*}{ Activity } & \multicolumn{7}{|c|}{ California Teaching Credential } & \multirow[b]{2}{*}{$\begin{array}{c}\stackrel{\vec{\Xi}}{0} \\
N=242\end{array}$} & \multirow[b]{2}{*}{ 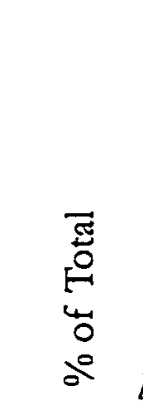 } & \multirow[b]{2}{*}{$\begin{array}{l}\text { Sig. } \\
p<.10\end{array}$} \\
\hline & 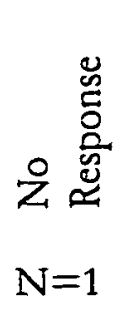 & 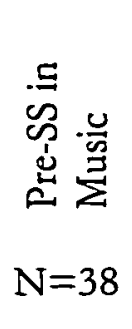 & 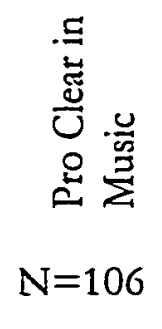 & 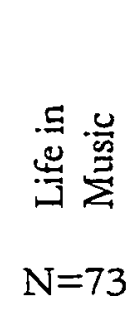 & 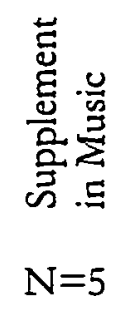 & $\begin{array}{l}\stackrel{\text { 돈 }}{\stackrel{D}{C}} \\
N=2\end{array}$ & 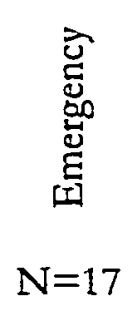 & & & \\
\hline $\begin{array}{l}\text { Service in a } \\
\text { Music Org. }\end{array}$ & 0 & 8 & 35 & 33 & 2 & 2 & 6 & 86 & $35.5 \%$ & $6 \quad .010$ \\
\hline $\begin{array}{l}\text { District } \\
\text { Sponsored } \\
\text { Workshops }\end{array}$ & 0 & 13 & 45 & 24 & 2 & 0 & 1 & 85 & $35.1 \%$ & 6. .080 \\
\hline $\begin{array}{l}\text { Peer } \\
\text { Mentoring } \\
\text { Activities }\end{array}$ & 0 & 10 & 22 & 21 & 2 & 0 & 4 & 59 & $24.3 \%$ & .538 \\
\hline $\begin{array}{l}\text { Non-Music } \\
\text { Conferences }\end{array}$ & 0 & 11 & 22 & 13 & 3 & 0 & 2 & 51 & $21.0 \%$ & .294 \\
\hline $\begin{array}{l}\text { Service as a } \\
\text { Mentor } \\
\text { Teacher }\end{array}$ & 0 & 3 & 21 & 20 & 2 & 1 & 1 & 48 & $19.8 \%$ & .081 \\
\hline $\begin{array}{l}\text { Educational } \\
\text { Research }\end{array}$ & 1 & 8 & 20 & 8 & 1 & 0 & 8 & 45 & $18.5 \%$ & .811 \\
\hline $\begin{array}{l}\text { County Office } \\
\text { of Ed. Wkshps }\end{array}$ & 0 & 1 & 9 & 12 & 1 & 0 & 3 & 26 & $10.7 \%$ & .011 \\
\hline $\begin{array}{l}\text { Beginning } \\
\text { Teacher } \\
\text { Support \& } \\
\text { Assessment }\end{array}$ & 0 & 11 & 6 & 3 & 0 & 0 & 4 & 24 & $09.9 \%$ & .032 \\
\hline $\begin{array}{l}\text { Online- } \\
\text { Distance } \\
\text { Learning }\end{array}$ & 0 & 4 & 10 & 5 & 0 & 0 & 0 & 19 & $07.8 \%$ & .156 \\
\hline Other & 0 & 2 & 8 & 5 & 0 & 0 & 2 & 17 & $07.0 \%$ & .722 \\
\hline
\end{tabular}

The participation rates for all respondents in New Music Reading Sessions is $57.4 \%$.

However, teachers that held preliminary single subject in music credentials attended $20.6 \%$ less and teachers with emergency credentials attended $28 \%$ less than the statistical average. 
On the other hand, teachers with professional clear single subject credentials and life credentials participated more than the population average.

Participation rates for all respondents in County Office of Education Workshops were $10.7 \%$ and Service in a Music Organizations rates were $35.5 \%$. However, teachers with preliminary single subject and professional clear single subject credentials participated less than the average while teachers with life credentials participated more.

Participation rates for all respondents in Additional College Coursework was $45.8 \%$ with the exception of teachers holding preliminary single subject and professional clear single subject credentials. This sub-group had participation rates higher (by $19.9 \%$ and $7.9 \%$ respectively) than the average, while teachers with life credentials had participation rates $25.3 \%$ lower than the average.

The final significant difference occurs in Service as a Mentor Teacher. Teachers in this sub-group of life credential holders participated $7.5 \%$ more than the statistical average. This is because life credentials were issued before September 1985, thus these teachers tend to provide mentor services more often than do other sub-groups.

Table 27 displays cross tabulations between the amount of district reimbursement to the survey population and types of the various professional growth activities attended. The data indicate that there are five activities in which the participation levels of the respondents vary significantly $(p<.10)$ from the average according to the amount of district reimbursement. These activities are (a) Music Conferences, (b) Music Workshops, (c) Observing Other Rehearsals, (d) County Office of Education Workshops, and (e) Other activities including performance as a musician, festival participation, conducting honor groups, etc. 
The participation rate for all respondents at Music Conferences is a high $88 \%$ and Music Workshops is $57.8 \%$. Yet those teachers receiving no reimbursement attended less than the average and teachers in groupings less than $\$ 500$ participated more than the average.

Teachers who said they observe music rehearsals had an overall participation rate of $78.9 \%$. Teachers who were reimbursed less than $\$ 200$ had a lower participation rate and teachers who were reimbursed from $\$ 200$ to $\$ 499$ had a higher participation rate than the statistical average.

In contrast to the trend mentioned previously, teachers who had no professional growth reimbursement had higher participation rates in County Office of Education Workshops, which are often free of charge, and in other activities such as performing as a musician, festival participation, conducting honor groups, etc. Teachers who received reimbursement up to $\$ 499$ had lower participation rates in these activities.

Table 27

Staff Development Activities Attended by Amount of District Reimbursement

\begin{tabular}{|c|c|c|c|c|c|c|c|c|c|}
\hline \multirow[b]{3}{*}{ Activity } & \multicolumn{5}{|c|}{ Amount of District Reimbursement } & \multirow{3}{*}{ 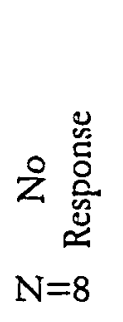 } & \multirow{3}{*}{$\begin{array}{c}\text { Total } \\
242\end{array}$} & \multirow{3}{*}{ 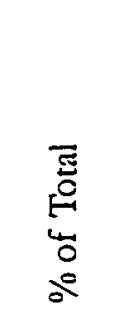 } & \multirow{3}{*}{$\begin{array}{c}\text { Sig. } \\
p<.10\end{array}$} \\
\hline & None & $<\$ 200$ & $\begin{array}{c}\$ 200 \\
\text { to } \\
\$ 499\end{array}$ & $\begin{array}{l}\$ 500 \\
\text { to } \\
\$ 999\end{array}$ & All \$ & & & & \\
\hline & $N=78$ & $N=62$ & $N=61$ & $N=10$ & $N=23$ & & & & \\
\hline $\begin{array}{l}\text { Attendance at } \\
\text { Concerts }\end{array}$ & 72 & 56 & 58 & 9 & 20 & 8 & 223 & $92.1 \%$ & .657 \\
\hline Music Conferences & 63 & 57 & 56 & 10 & 21 & 6 & 213 & $88.0 \%$ & .012 \\
\hline $\begin{array}{l}\text { Observing Other } \\
\text { Rehearsals }\end{array}$ & 58 & 47 & 52 & 9 & 19 & 6 & 191 & $78.9 \%$ & .091 \\
\hline $\begin{array}{l}\text { Hosting a Guest } \\
\text { Clinician/Teacher }\end{array}$ & 53 & 47 & 44 & 7 & 17 & 4 & 172 & $71.0 \%$ & .331 \\
\hline On-Campus Inservice & 45 & 28 & 40 & 6 & 17 & 5 & 141 & $58.2 \%$ & .182 \\
\hline
\end{tabular}




\begin{tabular}{|c|c|c|c|c|c|c|c|c|c|}
\hline \multirow{3}{*}{ Activity } & \multicolumn{5}{|c|}{ Amount of District Reimbursement } & \multirow{3}{*}{ 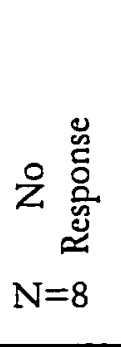 } & \multirow{3}{*}{$\begin{array}{l}\text { Total } \\
242\end{array}$} & \multirow{3}{*}{ 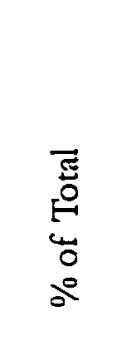 } & \multirow{3}{*}{$\begin{array}{l}\text { Sig. } \\
p<.10\end{array}$} \\
\hline & None & $N=62$ & $\begin{array}{c}\$ 200 \\
\text { to } \\
\$ 499 \\
\mathrm{~N}=61\end{array}$ & $\begin{array}{l}\$ 500 \\
\text { to } \\
\$ 999 \\
N=10\end{array}$ & All \$ & & & & \\
\hline & & & & & & & & & \\
\hline Music Workshops & 44 & 30 & 39 & 6 & 18 & 3 & 140 & $57.8 \%$ & .044 \\
\hline $\begin{array}{l}\text { Non-Music } \\
\text { Workshops }\end{array}$ & 47 & 34 & 39 & 4 & 12 & 4 & 140 & $57.8 \%$ & .768 \\
\hline $\begin{array}{l}\text { New Music Reading } \\
\text { Session }\end{array}$ & 40 & 39 & 37 & 7 & 14 & 2 & 191 & $57.4 \%$ & .064 \\
\hline $\begin{array}{l}\text { Being a Guest } \\
\text { Clinician/Teacher }\end{array}$ & 40 & 38 & 34 & 7 & 15 & 4 & 138 & $57.0 \%$ & .200 \\
\hline $\begin{array}{l}\text { Curriculum } \\
\text { Meetings }\end{array}$ & 41 & 34 & 29 & 5 & 13 & 3 & 125 & $51.6 \%$ & .947 \\
\hline $\begin{array}{l}\text { Additional College } \\
\text { Coursework }\end{array}$ & 37 & 26 & 30 & 6 & 10 & 2 & 111 & $45.8 \%$ & .566 \\
\hline $\begin{array}{l}\text { Service in a Music } \\
\text { Organization }\end{array}$ & 27 & 20 & 24 & 6 & 8 & 1 & 86 & $35.5 \%$ & .220 \\
\hline $\begin{array}{l}\text { District Sponsored } \\
\text { Workshops }\end{array}$ & 26 & 19 & 24 & 3 & 10 & 3 & 85 & $35.1 \%$ & .423 \\
\hline $\begin{array}{l}\text { Peer Mentoring } \\
\text { Activities }\end{array}$ & 19 & 11 & 20 & 2 & 6 & 1 & 59 & $24.3 \%$ & .347 \\
\hline $\begin{array}{l}\text { Non-Music } \\
\text { Conferences }\end{array}$ & 13 & 17 & 12 & 1 & 7 & 1 & 51 & $21.0 \%$ & .349 \\
\hline $\begin{array}{l}\text { Service as a Mentor } \\
\text { Teacher }\end{array}$ & 17 & 10 & 11 & 2 & 5 & 3 & 48 & $19.8 \%$ & .501 \\
\hline $\begin{array}{l}\text { Educational } \\
\text { Research }\end{array}$ & 16 & 9 & 11 & 3 & 4 & 2 & 45 & $18.5 \%$ & .799 \\
\hline $\begin{array}{l}\text { County Office of } \\
\text { Ed. Workshops }\end{array}$ & 13 & 3 & 6 & 0 & 2 & 2 & 26 & $10.7 \%$ & .048 \\
\hline $\begin{array}{l}\text { Beginning Teacher } \\
\text { Support \& } \\
\text { Assessment }\end{array}$ & 8 & 5 & 8 & 1 & 1 & 1 & 24 & $09.9 \%$ & .833 \\
\hline $\begin{array}{l}\text { Online/Distance } \\
\text { Learning }\end{array}$ & 6 & 6 & 4 & 0 & 1 & 2 & 19 & $07.8 \%$ & .201 \\
\hline Other & 8 & 2 & 4 & 0 & 1 & 2 & 17 & $07.0 \%$ & .066 \\
\hline
\end{tabular}


Table 28 presents cross tabulations between the number of high school instrumental teachers within a particular district and variety of the various professional growth activities attended during the past three years. The data indicate that there are five activities in which the participation levels of the respondents vary significantly $(p<.10)$ from the average according to the number of high school instrumental teachers in the district. These activities are (a) Non-Music Conferences, (b) Educational Research, (c) Being a Guest Teacher/Clinician, (d) District Sponsored Workshops, and (e) Other activities including performance as a musician, festival participation, conducting honor groups, etc.

The participation rate for all respondents in Non-Music Conferences was 21\%. Yet respondents with 4 or fewer music teachers in the district had a higher participation average and teachers with five or more in their district had a lower participation average.

Districts with only one teacher had higher participation rates than the average in the Other activity which includes activities such as performing as a musician, festival performance, or conducting honor groups, etc. The participation rate for all respondents in this activity was $7 \%$. Yet this sub-group participated slightly more frequently $(7.5 \%)$ than the average. 
Table 28

Staff Development Activities Attended by Number of High School Instrumental Teachers in the District

\begin{tabular}{|c|c|c|c|c|c|c|c|c|}
\hline \multirow[b]{2}{*}{ Activity } & \multicolumn{6}{|c|}{ HS Instrumental Music Teachers in the District } & \multirow[b]{2}{*}{ 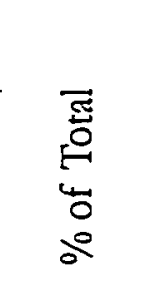 } & \multirow[b]{2}{*}{$\begin{array}{c}\text { Sig. } \\
p<.10\end{array}$} \\
\hline & $\begin{array}{c}1 \\
N=48\end{array}$ & $\begin{array}{c}2-4 \\
N=62\end{array}$ & $\begin{array}{c}5-9 \\
N=58\end{array}$ & $\begin{array}{l}10-19 \\
N=35\end{array}$ & $\begin{array}{c}20+ \\
N=35\end{array}$ & $\begin{array}{l}\text { Unknown } \\
\qquad \mathrm{N}=4\end{array}$ & & \\
\hline $\begin{array}{l}\text { Attendance at } \\
\text { Concerts }\end{array}$ & 43 & 57 & 54 & 34 & 31 & 4 & $92.1 \%$ & .576 \\
\hline Music Conferences & 41 & 56 & 50 & 31 & 32 & 3 & $88.0 \%$ & $.7-48$ \\
\hline $\begin{array}{l}\text { Observing Other } \\
\text { Rehearsals }\end{array}$ & 35 & 52 & 45 & 26 & 29 & 4 & $78.9 \%$ & .536 \\
\hline $\begin{array}{l}\text { Hosting a Guest } \\
\text { Clinician/Teacher }\end{array}$ & 27 & 49 & 39 & 30 & 25 & 2 & $71.0 \%$ & .1 .56 \\
\hline $\begin{array}{l}\text { On-Campus } \\
\text { Inservice }\end{array}$ & 28 & 38 & 34 & 21 & 18 & 2 & $58.2 \%$ & $.5-48$ \\
\hline Music Workshops & 36 & 39 & 33 & 23 & 18 & 1 & $57.8 \%$ & $.7-44$ \\
\hline $\begin{array}{l}\text { Non-Music } \\
\text { Workshops }\end{array}$ & 26 & 39 & 32 & 20 & 19 & 4 & $57.8 \%$ & .891 \\
\hline $\begin{array}{l}\text { New Music } \\
\text { Reading Session }\end{array}$ & 27 & 38 & 36 & 21 & 17 & 139 & $57.4 \%$ & .3 .23 \\
\hline $\begin{array}{l}\text { Being a Guest } \\
\text { Clinician/Teacher }\end{array}$ & 20 & 38 & 33 & 26 & 18 & 3 & $57.0 \%$ & .0 .94 \\
\hline $\begin{array}{l}\text { Curriculum } \\
\text { Meetings }\end{array}$ & 23 & 37 & 27 & 20 & 17 & 1 & $51.6 \%$ & .710 \\
\hline $\begin{array}{l}\text { Additional College } \\
\text { Coursework }\end{array}$ & 22 & 25 & 28 & 18 & 17 & 1 & $45.8 \%$ & $.5 \cdot 84$ \\
\hline $\begin{array}{l}\text { Service in a Music } \\
\text { Organization }\end{array}$ & 18 & 21 & 23 & 15 & 9 & 0 & $35.5 \%$ & $.4-92$ \\
\hline $\begin{array}{l}\text { District Sponsored } \\
\text { Workshops }\end{array}$ & 10 & 22 & 21 & 19 & 13 & 0 & $35.1 \%$ & $.0 \cdot 48$ \\
\hline $\begin{array}{l}\text { Peer Mentoring } \\
\text { Activities }\end{array}$ & 8 & 19 & 9 & 11 & 12 & 0 & $24.3 \%$ & $.2: 83$ \\
\hline
\end{tabular}




\begin{tabular}{|c|c|c|c|c|c|c|c|c|}
\hline \multirow[b]{2}{*}{ Activity } & \multicolumn{6}{|c|}{ HS Instrumental Music Teachers in the District } & \multirow[b]{2}{*}{ 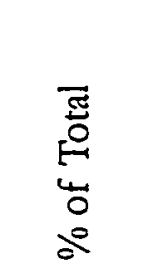 } & \multirow[b]{2}{*}{$\begin{array}{l}\text { Sig. } \\
p<.10\end{array}$} \\
\hline & $\begin{array}{c}1 \\
N=48\end{array}$ & $\begin{array}{c}2-4 \\
N=62\end{array}$ & $\begin{array}{c}5-9 \\
N=58\end{array}$ & $\begin{array}{l}10-19 \\
N=35\end{array}$ & $\begin{array}{l}20+ \\
N=35\end{array}$ & $\begin{array}{l}\text { Unknown } \\
\qquad N=4\end{array}$ & & \\
\hline $\begin{array}{l}\text { Non-Music } \\
\text { Conferences }\end{array}$ & 12 & 17 & 11 & 5 & 5 & 1 & $21.0 \%$ & .088 \\
\hline $\begin{array}{l}\text { Service as a } \\
\text { Mentor Teacher }\end{array}$ & 8 & 15 & 11 & 10 & 4 & 0 & $19.8 \%$ & .698 \\
\hline $\begin{array}{l}\text { Educational } \\
\text { Research }\end{array}$ & 4 & 12 & 12 & 7 & 8 & 2 & $18.5 \%$ & .050 \\
\hline $\begin{array}{l}\text { County Office of } \\
\text { Ed. Workshops }\end{array}$ & 7 & 8 & 4 & 3 & 4 & 0 & $10.7 \%$ & .287 \\
\hline $\begin{array}{l}\text { Beginning Teacher } \\
\text { Support \& } \\
\text { Assessment }\end{array}$ & 4 & 11 & 4 & 0 & 4 & 1 & $09.9 \%$ & .413 \\
\hline $\begin{array}{l}\text { Online/Distance } \\
\text { Learning }\end{array}$ & 4 & 6 & 2 & 3 & 4 & 0 & $07.8 \%$ & .965 \\
\hline Other & 7 & 4 & 3 & 1 & 2 & 0 & $07.0 \%$ & .051 \\
\hline
\end{tabular}

The involvement rate for all respondents in Educational Research is $18.5 \%$ and District Sponsored Workshops is $35.1 \%$ (see Table 28 ). But those teachers with only one high school instrumental teacher in the district had lower participation rates than the average and teachers with two or more in the district had higher levels of participation.

The same data ratio exists for Being a Guest Teacher or Clinician with the exception of teachers in districts with more than 20 high school instrumental teachers. This sub-group had levels of involvement less than the average by $6 \%$.

Table 29 illustrates cross tabulations between the size of the school and types of professional growth activities attended during the past three years. The data indicate that there are three activities in which the participation levels of the respondents vary significantly $(p<.10)$ from the average according to the size of school. These activities are (a) 
Being a Guest 'Teacher or Clinician, (b) Hosting a Guest Teacher or Clinician, and (c)

District Sponsored Workshops.

Participation rates for the survey population in Being a Guest Teacher or Clinician is $57 \%$. However teachers with school populations of 999 or less and 1500 to 1999 had lower rates of participation than the average while schools with populations of 1000 to 1499 and greater than 2000 had participation levels higher than the average.

Hosting a clinician or guest teacher and District Sponsored Workshops had participation rates of $71 \%$ and $35.1 \%$ respectively. The data indicate that schools with less than 1500 students had instrumental music teachers participate less than the average and schools with more than 1500 had those teachers participate at rates greater than the average.

The most significant statistic is the low level of participation in District Sponsored Workshops by teachers from schools with less than 500 students. These teachers participate $28.9 \%$ less in District Sponsored Workshop activities than the average for all respondents, which was $35.1 \%$.

Table 29

Staff Development Activities Attended by School Size

\begin{tabular}{|c|c|c|c|c|c|c|c|c|}
\hline \multirow[b]{3}{*}{ Activity } & \multicolumn{6}{|c|}{ School Size } & \multirow{3}{*}{ 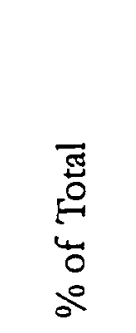 } & \multirow{3}{*}{$\begin{array}{l}\text { Significance } \\
\qquad p<.10\end{array}$} \\
\hline & $<499$ & $\begin{array}{c}500 \\
\text { to } \\
999\end{array}$ & $\begin{array}{c}1000 \\
1499\end{array}$ & $\begin{array}{c}1500- \\
1999\end{array}$ & $\begin{array}{c}2000- \\
2499\end{array}$ & $2500+$ & & \\
\hline & $N=16$ & $N=18$ & $N=31$ & $N=53$ & $N=62$ & $N=62$ & & \\
\hline $\begin{array}{l}\text { Attendance at } \\
\text { Concerts }\end{array}$ & 14 & 13 & 29 & 50 & 61 & 55 & $92.1 \%$ & .193 \\
\hline Music Conferences & 11 & 15 & 29 & 48 & 54 & 55 & $88.0 \%$ & .269 \\
\hline $\begin{array}{l}\text { Observing Other } \\
\text { Rehearsals }\end{array}$ & 10 & 11 & 26 & 45 & 46 & 52 & $78.9 \%$ & .112 \\
\hline
\end{tabular}




\begin{tabular}{|c|c|c|c|c|c|c|c|c|}
\hline \multirow[b]{3}{*}{ Activity } & \multicolumn{6}{|c|}{ School Size } & \multirow{3}{*}{$\begin{array}{l}\bar{E} \\
0 \\
0 \\
0 \\
0 \\
0\end{array}$} & \multirow{3}{*}{$\begin{array}{c}\text { Significance } \\
p<.10\end{array}$} \\
\hline & $<499$ & $\begin{array}{c}500 \\
\text { to } \\
999\end{array}$ & $\begin{array}{c}1000- \\
1499\end{array}$ & $\begin{array}{c}1500 \\
1999\end{array}$ & $\begin{array}{c}2000 \\
2499\end{array}$ & $2500+$ & & \\
\hline & $N=16$ & $\mathrm{~N}=18$ & $N=31$ & $\mathrm{~N}=53$ & $N=62$ & $N=62$ & & \\
\hline $\begin{array}{l}\text { Hosting a Guest } \\
\text { Clinician/Teacher }\end{array}$ & 4 & 8 & 18 & 39 & 49 & 53 & $71.0 \%$ & .000 \\
\hline $\begin{array}{l}\text { On-Campus } \\
\text { Inservice }\end{array}$ & 9 & 11 & 23 & 28 & 35 & 35 & $58.2 \%$ & .412 \\
\hline Music Workshops & 6 & 9 & 23 & 30 & 34 & 38 & $57.8 \%$ & .593 \\
\hline $\begin{array}{l}\text { Non-Music } \\
\text { Workshops }\end{array}$ & 6 & 9 & 24 & 30 & 35 & 36 & $57.8 \%$ & .911 \\
\hline $\begin{array}{l}\text { New Music } \\
\text { Reading Session }\end{array}$ & 6 & 8 & 23 & 30 & 35 & 37 & $57.4 \%$ & .549 \\
\hline $\begin{array}{l}\text { Being a Guest } \\
\text { Clinician/Teacher }\end{array}$ & 3 & 8 & 21 & 29 & 39 & 38 & $57.0 \%$ & .050 \\
\hline $\begin{array}{l}\text { Curriculum } \\
\text { Meetings }\end{array}$ & 5 & 8 & 17 & 26 & 34 & 35 & $51.6 \%$ & .148 \\
\hline $\begin{array}{l}\text { Additional } \\
\text { College } \\
\text { Coursework }\end{array}$ & 7 & 8 & 12 & 28 & 26 & 30 & $45.8 \%$ & .749 \\
\hline $\begin{array}{l}\text { Service in a Music } \\
\text { Organization }\end{array}$ & 6 & 5 & 9 & 21 & 20 & 25 & $35.5 \%$ & .461 \\
\hline $\begin{array}{l}\text { District } \\
\text { Sponsored } \\
\text { Workshops }\end{array}$ & 1 & 3 & 10 & 23 & 22 & 26 & $35.1 \%$ & .023 \\
\hline $\begin{array}{l}\text { Peer Mentoring } \\
\text { Activities }\end{array}$ & 3 & 2 & 10 & 14 & 16 & 14 & $24.3 \%$ & .927 \\
\hline $\begin{array}{l}\text { Non-Music } \\
\text { Conferences }\end{array}$ & 6 & 4 & 4 & 13 & 9 & 15 & $21.0 \%$ & .753 \\
\hline $\begin{array}{l}\text { Service as a } \\
\text { Mentor Teacher }\end{array}$ & 3 & 2 & 10 & 10 & 7 & 16 & $19.8 \%$ & .838 \\
\hline
\end{tabular}




\begin{tabular}{|c|c|c|c|c|c|c|c|c|}
\hline \multirow[b]{3}{*}{ Activity } & \multicolumn{6}{|c|}{ School Size } & \multirow{3}{*}{ 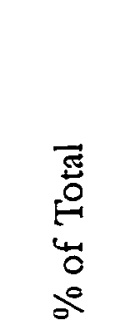 } & \multirow{3}{*}{$\begin{array}{l}\text { Significance } \\
\qquad p<.10\end{array}$} \\
\hline & \multirow{2}{*}{$\begin{array}{l}<499 \\
N=16\end{array}$} & \multirow{2}{*}{$\begin{array}{c}500 \\
\text { to } \\
999 \\
\mathrm{~N}=18\end{array}$} & \multirow{2}{*}{$\begin{array}{c}1000- \\
1499 \\
N=31\end{array}$} & \multirow{2}{*}{$\begin{array}{l}1500- \\
1999 \\
N=53\end{array}$} & \multirow{2}{*}{$\begin{array}{c}2000 \\
2499 \\
N=62\end{array}$} & \multirow{2}{*}{$\begin{array}{l}2500+ \\
N=62\end{array}$} & & \\
\hline & & & & & & & & \\
\hline $\begin{array}{l}\text { Educational } \\
\text { Research }\end{array}$ & 1 & 2 & 6 & 12 & 12 & 11 & $18.5 \%$ & .395 \\
\hline $\begin{array}{l}\text { County Office of } \\
\text { Ed. Workshops }\end{array}$ & 3 & 1 & 4 & 3 & 7 & 8 & $10.7 \%$ & .756 \\
\hline $\begin{array}{l}\text { Beginning } \\
\text { Teacher Support } \\
\text { \& Assessment }\end{array}$ & 2 & 0 & 3 & 5 & 4 & 10 & $09.9 \%$ & .188 \\
\hline $\begin{array}{l}\text { Online/Distance } \\
\text { Learning }\end{array}$ & 0 & 3 & 3 & 4 & 4 & 5 & $07.8 \%$ & .832 \\
\hline Other & 4 & 1 & 2 & 2 & 2 & 6 & $07.0 \%$ & .565 \\
\hline
\end{tabular}

Note. Total number of responses was $241(\mathrm{~N}=241)$. One person did not indicate a school size.

Table 30 presents cross tabulations between the location of the high school instrumental teacher's school and types of professional growth activities attended during the past three years. The data indicate that there are two activities in which the participation levels of the respondents vary significantly $(\phi<.10)$ from the average according to the school location. These activities are (a) District Sponsored Workshops, and (b) Other activities including performance as a musician, festival participation, conducting honor groups, etc.

Average participation rates for teachers who participated in District Sponsored Workshops is $35.1 \%$. However, teachers in rural schools had lower participation rates than the average, and teachers from suburban and urban schools had higher participation rates. In fact, rural teachers participate in District Sponsored Workshops at rates of $17.3 \%$, which is less than half the $35.1 \%$ average. 
Table 30

Staff Development Activities Attended by School Location

\begin{tabular}{|c|c|c|c|c|c|c|}
\hline \multirow[b]{2}{*}{ Activity } & \multicolumn{3}{|c|}{ School Location } & \multirow[b]{2}{*}{$\begin{array}{l}\text { Total } \\
242\end{array}$} & \multirow{2}{*}{ 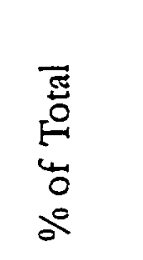 } & \multirow[b]{2}{*}{$\begin{array}{c}\text { Significance } \\
\qquad p<.10\end{array}$} \\
\hline & $\begin{array}{l}\text { Rural } \\
N=56\end{array}$ & $\begin{array}{l}\text { Suburban } \\
N=117\end{array}$ & $\begin{array}{l}\text { Urban } \\
N=69\end{array}$ & & & \\
\hline Attendance at Concerts & 50 & 111 & 62 & 223 & $92.1 \%$ & .975 \\
\hline Music Conferences & 45 & 111 & 57 & 213 & $88.0 \%$ & .942 \\
\hline Observing Other Rehearsals & 42 & 100 & 49 & 191 & $78.9 \%$ & .440 \\
\hline $\begin{array}{l}\text { Hosting a Guest } \\
\text { Clinician/Teacher }\end{array}$ & 31 & 95 & 46 & 172 & $71.0 \%$ & .295 \\
\hline On-Campus Inservice & 33 & 67 & 41 & 141 & $58.2 \%$ & .933 \\
\hline Music Workshops & 30 & 75 & 35 & 140 & $57.8 \%$ & .615 \\
\hline Non-Music Workshops & 27 & 73 & 40 & 140 & $57.8 \%$ & .340 \\
\hline New Music Reading Session & 29 & 78 & 32 & 191 & $57.4 \%$ & .381 \\
\hline $\begin{array}{l}\text { Being a Guest } \\
\text { Clinician/Teacher }\end{array}$ & 24 & 86 & 28 & 138 & $57.0 \%$ & .459 \\
\hline Curriculum Meetings & 22 & 67 & 36 & 125 & $51.6 \%$ & .208 \\
\hline $\begin{array}{l}\text { Additional College } \\
\text { Coursework }\end{array}$ & 27 & 56 & 28 & 111 & $45.8 \%$ & .367 \\
\hline $\begin{array}{l}\text { Service in a Music } \\
\text { Organization }\end{array}$ & 18 & 52 & 16 & 86 & $35.5 \%$ & .192 \\
\hline $\begin{array}{l}\text { District Sponsored } \\
\text { Workshops }\end{array}$ & 10 & 49 & 26 & 85 & $35.1 \%$ & .037 \\
\hline Peer Mentoring Activities & 10 & 30 & 19 & 59 & $24.3 \%$ & .230 \\
\hline Non-Music Conferences & 14 & 24 & 13 & 51 & $21.0 \%$ & .417 \\
\hline Service as a Mentor Teacher & 10 & 26 & 12 & 48 & $19.8 \%$ & .879 \\
\hline Educational Research & 5 & 28 & 12 & 45 & $18.5 \%$ & .318 \\
\hline $\begin{array}{l}\text { County Office of Ed. } \\
\text { Workshops }\end{array}$ & 10 & 9 & 7 & 26 & $10.7 \%$ & .219 \\
\hline $\begin{array}{l}\text { Beginning Teacher Support } \\
\text { \& Assessment }\end{array}$ & 4 & 10 & 10 & 24 & $09.9 \%$ & .155 \\
\hline
\end{tabular}




\begin{tabular}{|c|c|c|c|c|c|c|}
\hline \multirow[b]{3}{*}{ Activity } & \multicolumn{3}{|c|}{ School Location } & \multirow{3}{*}{$\begin{array}{l}\text { Total } \\
242\end{array}$} & \multirow{3}{*}{ 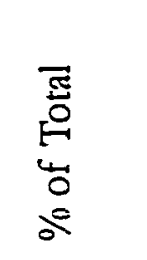 } & \multirow{3}{*}{$\begin{array}{l}\text { Significance } \\
\qquad p<.10\end{array}$} \\
\hline & Rural & Suburban & Urban & & & \\
\hline & $N=56$ & $N=117$ & $N=69$ & & & \\
\hline Online/Distance Learning & 4 & 11 & 4 & 19 & $07.8 \%$ & .719 \\
\hline Other & 8 & 7 & 2 & 17 & $07.0 \%$ & .016 \\
\hline
\end{tabular}

The opposite is true of the data from the Other activity. The average participation rate for this activity is $7 \%$. Yet rural teachers had higher rates of participation and suburban and urban teachers had lower rates than the average. Rural teachers participate in other activities $7.2 \%$ higher than the average of this activity, which is $7 \%$.

Table 31 shows cross tabulations between the number of students in the instrumental music program and types of various professional growth activities attended during the past three years. The data indicate that there are ten activities in which the participation levels of the respondents vary significantly $(p<.10)$ from the average according to the number of students in the program. These activities are (a) Music Conferences, (b) New Music Reading Sessions, (c) Service as a Mentor Teacher, (d) Service in a Music Organization, (e) Being a Guest Teacher or Clinician, (f) Hosting a Guest Teacher or Clinician, (g) Attendance at Concerts, (h) District Sponsored Workshops, (i) Music Workshops, and (j) Other activities including performance as a musician, festival participation, conducting honor groups, etc.

In nine out of the previously listed ten activities, high school instrumental music teachers with fewer than 75 students in their program had lower participation rates than the average. The one exception was in the Other activity. The participation rate for all respondents in this activity was $7 \%$ and teachers with fewer than 75 students and more than 225 students participated more than the average (7\% and $3 \%$ respectively). 
Participation rates for all respondents in attendance at Music Conferences were $88 \%$. However teachers with programs less than 125 had lower participation rates and programs with 125 or more had higher participation rates. The same data (see Table 31) are reflected in Attendance at Concerts.

Music Workshops had mixture of attendance rates. Teachers with fewer than 75 students and between $125-174$ students had lower participation rates than the $57.8 \%$ average. Teachers with program enrollments of 76-124 and greater than 175 had higher participation rates than the $57.8 \%$ average.

Attendance at New Music Reading Sessions indicated that teachers with low $(<75)$ enrollments participated $18.9 \%$ less than rile $57.4 \%$ average while teachers with programs of more than 175 students participated more than the average.

Participation rates for Serving as a Mentor Teacher is $19.8 \%$ and Being a Guest Teacher or Clinician is 57\%. Yet teachers with enrollments of fewer than 175 students were less active as mentor teachers and guest clinicians while teachers with programs more than 175 were more active as mentor teachers and guest clinicians.

Teachers with less than 75 students in their program participated less often in Music Organizations while teachers with more than 75 students participated at greater levels compared to the population average.

Participation rates for Hosting a Guest Teacher or Clinician was 71\%. However, teachers with fewer than 75 students participated $28.9 \%$ less than the average in hosting a guest teacher and teachers from all the other sub-groups participated above the average.

District Sponsored Workshops had an average participation rate of 35.1\%. Again, programs with fewer than 75 students participated $14.1 \%$ less than the $35.1 \%$ average while all other sub-groups participated more than the average. 
Table 31

Staff Development Activities Attended by Number of Students in the Program

\begin{tabular}{|c|c|c|c|c|c|c|c|}
\hline \multirow[b]{3}{*}{ Activity } & \multicolumn{5}{|c|}{ Number of Students in the Program } & \multirow{3}{*}{$\begin{array}{l}\text { 吾 } \\
0 \\
0 \\
0 \\
0 \\
0\end{array}$} & \multirow{3}{*}{$\begin{array}{l}\text { Significance } \\
\qquad p<.10\end{array}$} \\
\hline & $<75$ & $\begin{array}{c}76 \text { to } \\
124\end{array}$ & $\begin{array}{c}125 \text { to } \\
174\end{array}$ & $\begin{array}{c}175 \text { to } \\
224\end{array}$ & $225+$ & & \\
\hline & $N=57$ & $N=59$ & $N=54$ & $\mathrm{~N}=32$ & $N=40$ & & \\
\hline $\begin{array}{l}\text { Attendance at } \\
\text { Concerts }\end{array}$ & 49 & 53 & 51 & 32 & 38 & $92.1 \%$ & .017 \\
\hline Music Conferences & 39 & 51 & 52 & 32 & 39 & $88.0 \%$ & .000 \\
\hline $\begin{array}{l}\text { Observing Other } \\
\text { Rehearsals }\end{array}$ & 39 & 48 & 47 & 27 & 30 & $78.9 \%$ & .201 \\
\hline $\begin{array}{l}\text { Hosting a Guest } \\
\text { Clinician/Teacher }\end{array}$ & 24 & 47 & 39 & 29 & 33 & $71.0 \%$ & .000 \\
\hline $\begin{array}{l}\text { On-Campus } \\
\text { Inservice }\end{array}$ & 35 & 41 & 24 & 20 & 21 & $58.2 \%$ & .181 \\
\hline Music Workshops & 25 & 39 & 27 & 23 & 26 & $57.8 \%$ & .044 \\
\hline $\begin{array}{l}\text { Non-Music } \\
\text { Workshops }\end{array}$ & 34 & 38 & 30 & 17 & 21 & $57.8 \%$ & .279 \\
\hline $\begin{array}{l}\text { New Music Reading } \\
\text { Session }\end{array}$ & 22 & 34 & 31 & 26 & 26 & $57.4 \%$ & .001 \\
\hline $\begin{array}{l}\text { Being a Guest } \\
\text { Clinician/Teacher }\end{array}$ & 23 & 34 & 29 & 24 & 28 & $57.0 \%$ & .001 \\
\hline Curriculum Meetings & 25 & 30 & 27 & 19 & 24 & $51.6 \%$ & .089 \\
\hline $\begin{array}{l}\text { Additional College } \\
\text { Coursework }\end{array}$ & 27 & 24 & 26 & 20 & 14 & $45.8 \%$ & .941 \\
\hline $\begin{array}{l}\text { Service in a Music } \\
\text { Organization }\end{array}$ & 11 & 22 & 20 & 15 & 18 & $35.5 \%$ & .004 \\
\hline $\begin{array}{l}\text { District Sponsored } \\
\text { Workshops }\end{array}$ & 12 & 22 & 21 & 14 & 16 & $35.1 \%$ & .027 \\
\hline $\begin{array}{l}\text { Peer Mentoring } \\
\text { Activities }\end{array}$ & 11 & 19 & 9 & 9 & 11 & $24.3 \%$ & .630 \\
\hline $\begin{array}{l}\text { Non-Music } \\
\text { Conferences }\end{array}$ & 14 & 16 & 7 & 9 & 5 & $21.0 \%$ & .165 \\
\hline
\end{tabular}




\begin{tabular}{|c|c|c|c|c|c|c|c|}
\hline \multirow[b]{3}{*}{ Activity } & \multicolumn{5}{|c|}{ Number of Students in the Program } & \multirow{3}{*}{ 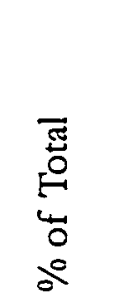 } & \multirow{3}{*}{$\begin{array}{l}\text { Significance } \\
\qquad<<.10\end{array}$} \\
\hline & $<75$ & $\begin{array}{c}76 \text { to } \\
124\end{array}$ & $\begin{array}{c}125 \text { to } \\
174\end{array}$ & $\begin{array}{l}175 \text { to } \\
224\end{array}$ & $225+$ & & \\
\hline & $N=57$ & $N=59$ & $N=54$ & $\mathrm{~N}=32$ & $N=40$ & & \\
\hline $\begin{array}{l}\text { Service as a Mentor } \\
\text { Teacher }\end{array}$ & 6 & 11 & 10 & 7 & 14 & $19.8 \%$ & .006 \\
\hline Educational Research & 10 & 13 & 7 & 8 & 7 & $18.5 \%$ & .986 \\
\hline $\begin{array}{l}\text { County Office of } \\
\text { Ed. Workshops }\end{array}$ & 9 & 6 & 2 & 3 & 6 & $10.7 \%$ & .556 \\
\hline $\begin{array}{l}\text { Beginning Teacher } \\
\text { Support \& } \\
\text { Assessment }\end{array}$ & 5 & 8 & 5 & 1 & 5 & $09.9 \%$ & .854 \\
\hline $\begin{array}{l}\text { Online/Distance } \\
\text { Learning }\end{array}$ & 4 & 4 & 3 & 4 & 4 & $07.8 \%$ & .439 \\
\hline Other & 8 & 4 & 1 & 0 & 4 & $07.0 \%$ & .097 \\
\hline
\end{tabular}

Table 32 illustrates cross tabulations between the sex of the survey population and variety of various professional growth activities attended during the past three years. The data indicate that there was one activity in which the participation levels of the respondents vary significantly $(p<.10)$ from the average according to sex of the survey population. This activity was Hosting a Guest Teacher or Clinician.

The participation rate for Hosting a Guest Teacher or Clinician for both sexes was $71 \%$. Yet males hosted a clinician $3.6 \%$ more often and females hosted a clinician $13.9 \%$ less often than the average.

While practically significant $(p=.101)$ but not at the .10 significance level, women participated less often in New Music Reading Sessions than men. In addition, the participation rate for County Office of Education Workshops was 10 out of 242 with a 
significance of $p=.103$. Again, these data hold practical significance indicating that women participated more often than men in County Office of Education Workshops.

Table 32

Staff Development Activities Attended by Sex

\begin{tabular}{|c|c|c|c|c|c|c|}
\hline \multirow[b]{3}{*}{ Activity } & \multicolumn{3}{|c|}{ Sex } & \multirow[b]{2}{*}{ Total } & \multirow{3}{*}{$\begin{array}{l}\vec{\Xi} \\
0 \\
0 \\
0 \\
0\end{array}$} & \multirow{3}{*}{$\begin{array}{c}\text { Significance } \\
p<.10\end{array}$} \\
\hline & Male & Female & $\begin{array}{c}\text { No } \\
\text { Response }\end{array}$ & & & \\
\hline & $N=197$ & $\mathrm{~N}=42$ & $N=3$ & $N=242$ & & \\
\hline Attendance at Concerts & 183 & 37 & 3 & 223 & $92.1 \%$ & .391 \\
\hline Music Conferences & 176 & 34 & 3 & 213 & $88.0 \%$ & .204 \\
\hline $\begin{array}{l}\text { Observing Other } \\
\text { Rehearsals }\end{array}$ & 156 & 33 & 2 & 191 & $78.9 \%$ & .816 \\
\hline $\begin{array}{l}\text { Hosting a Guest } \\
\text { Clinician/Teacher }\end{array}$ & 147 & 24 & 1 & 172 & $71.0 \%$ & .010 \\
\hline On-Campus Inservice & 113 & 26 & 2 & 141 & $58.2 \%$ & .548 \\
\hline Music Workshops & 115 & 25 & 0 & 140 & $57.8 \%$ & .655 \\
\hline Non-Music Workshops & 115 & 22 & 3 & 140 & $57.8 \%$ & .794 \\
\hline $\begin{array}{l}\text { New Music Reading } \\
\text { Session }\end{array}$ & 118 & 20 & 1 & 139 & $57.4 \%$ & .101 \\
\hline $\begin{array}{l}\text { Being a Guest } \\
\text { Clinician/Teacher }\end{array}$ & 118 & 19 & 1 & 138 & $57.0 \%$ & .057 \\
\hline Curriculum Meetings & 101 & 23 & 1 & 125 & $51.6 \%$ & .832 \\
\hline $\begin{array}{l}\text { Additional College } \\
\text { Coursework }\end{array}$ & 90 & 21 & 0 & 111 & $45.8 \%$ & .974 \\
\hline $\begin{array}{l}\text { Service in a Music } \\
\text { Organization }\end{array}$ & 73 & 13 & 0 & 86 & $35.5 \%$ & .279 \\
\hline $\begin{array}{l}\text { District Sponsored } \\
\text { Workshops }\end{array}$ & 71 & 14 & 0 & 85 & $35.1 \%$ & .496 \\
\hline Peer Mentoring Activities & 47 & 12 & 0 & 59 & $24.3 \%$ & .736 \\
\hline Non-Music Conferences & 43 & 7 & 1 & 51 & $21.0 \%$ & .574 \\
\hline
\end{tabular}




\begin{tabular}{|c|c|c|c|c|c|c|}
\hline \multirow[b]{3}{*}{ Activity } & \multicolumn{3}{|c|}{ Sex } & \multirow[b]{2}{*}{ Total } & \multirow{3}{*}{ 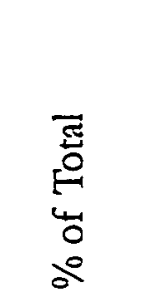 } & \multirow{3}{*}{$\begin{array}{c}\text { Significance } \\
p<.10\end{array}$} \\
\hline & Male & Fermale & $\begin{array}{l}\text { No } \\
\text { Response }\end{array}$ & & & \\
\hline & $N=197$ & $\mathrm{~N}=42$ & $N=3$ & $\mathrm{~N}=242$ & & \\
\hline $\begin{array}{l}\text { Service as a Mentor } \\
\text { Teacher }\end{array}$ & 41 & 7 & 0 & 48 & $19.8 \%$ & .407 \\
\hline Educational Research & 37 & 8 & 0 & 45 & $18.5 \%$ & .844 \\
\hline $\begin{array}{l}\text { County Office of Ed. } \\
\text { Workshops }\end{array}$ & 18 & 8 & 0 & 26 & $10.7 \%$ & .103 \\
\hline $\begin{array}{l}\text { Beginning Teacher } \\
\text { Support \& Assessment }\end{array}$ & 20 & 3 & 1 & 24 & $09.9 \%$ & .858 \\
\hline $\begin{array}{l}\text { Online/Distance } \\
\text { Learning }\end{array}$ & 15 & 4 & 0 & 19 & $07.8 \%$ & .799 \\
\hline Other & 13 & 3 & 1 & 17 & $07.0 \%$ & .531 \\
\hline
\end{tabular}

Table 33 presents cross tabulations between the race of the survey population and types of the various professional growth activities attended during the past three years. The data indicate that there is one activity in which the participation levels of the respondents vary significantly $(p<.10)$ from the average according to the race of the survey population. This activity is Educational Research.

Educational Research had average participation rates of $18.5 \%$ for all respondents in this activity. Those who did not indicate their gender participated in Educational Research activities at a rate that was $8.4 \%$ lower than the average of all respondents who selected this activity. Those who chose to identify their race participated in Educational Research at a higher than average rate.

While practically significant $(p=.108)$ but not at the level required for this study is the participation rates for taking Additional College Coursework. Caucasians took Additional College Coursework more often than those who chose not to indicate a race did. 
Table 33

Staff Development Activities Attended by Race

\begin{tabular}{|c|c|c|c|c|c|c|}
\hline \multirow[b]{3}{*}{ Activity } & \multicolumn{3}{|c|}{ Race } & \multirow[b]{2}{*}{ Total } & \multirow{3}{*}{ 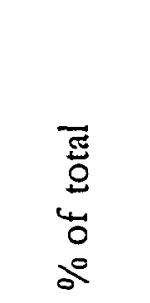 } & \multirow{3}{*}{$\begin{array}{l}\text { Significance } \\
\qquad p<.10\end{array}$} \\
\hline & Caucasian & $\begin{array}{l}\text { Non- } \\
\text { Caucasian }\end{array}$ & $\begin{array}{c}\text { No } \\
\text { Response }\end{array}$ & & & \\
\hline & $N=149$ & $\mathrm{~N}=24$ & $N=69$ & $N=242$ & & \\
\hline Attendance at Concerts & 138 & 22 & 63 & 223 & $92.1 \%$ & .730 \\
\hline Music Conferences & 130 & 21 & 62 & 213 & $88.0 \%$ & .605 \\
\hline $\begin{array}{l}\text { Observing Other } \\
\text { Rehearsals }\end{array}$ & 116 & 20 & 55 & 191 & $78.9 \%$ & .670 \\
\hline $\begin{array}{l}\text { Hosting a Guest } \\
\text { Clinician/Teacher }\end{array}$ & 102 & 17 & 53 & 172 & $71.0 \%$ & .221 \\
\hline On-Campus Inservice & 88 & 17 & 38 & 141 & $58.2 \%$ & .945 \\
\hline Music Workshops & 88 & 13 & 39 & 140 & $57.8 \%$ & .669 \\
\hline Non-Music Workshops & 85 & 15 & 40 & 140 & $57.8 \%$ & .817 \\
\hline $\begin{array}{l}\text { New Music Reading } \\
\text { Session }\end{array}$ & 91 & 11 & 37 & 139 & $57.4 \%$ & .203 \\
\hline $\begin{array}{l}\text { Being a Guest } \\
\text { Clinician/Teacher }\end{array}$ & 84 & 14 & 40 & 138 & $57.0 \%$ & .807 \\
\hline Curriculum Meetings & 79 & 14 & 32 & 125 & $51.6 \%$ & .462 \\
\hline $\begin{array}{l}\text { Additional College } \\
\text { Coursework }\end{array}$ & 74 & 11 & 26 & 111 & $45.8 \%$ & .108 \\
\hline $\begin{array}{l}\text { Service in a Music } \\
\text { Organization }\end{array}$ & 57 & 9 & 20 & 86 & $35.5 \%$ & .213 \\
\hline $\begin{array}{l}\text { District Sponsored } \\
\text { Workshops }\end{array}$ & 55 & 12 & 18 & 85 & $35.1 \%$ & .246 \\
\hline $\begin{array}{l}\text { Peer Mentoring } \\
\text { Activities }\end{array}$ & 32 & 8 & 19 & 59 & $24.3 \%$ & .239 \\
\hline $\begin{array}{l}\text { Non-Music } \\
\text { Conferences }\end{array}$ & 29 & 6 & 16 & 51 & $21.0 \%$ & .473 \\
\hline $\begin{array}{l}\text { Service as a Mentor } \\
\text { Teacher }\end{array}$ & 30 & 4 & 14 & 48 & $19.8 \%$ & .949 \\
\hline Educational Research & 32 & 6 & 7 & 45 & $18.5 \%$ & .078 \\
\hline
\end{tabular}




\begin{tabular}{|c|c|c|c|c|c|c|}
\hline \multirow[b]{3}{*}{ Activity } & \multicolumn{3}{|c|}{ Race } & \multirow{3}{*}{$\begin{array}{l}\text { Total } \\
N=242\end{array}$} & \multirow{3}{*}{$\begin{array}{l}\text { 吾 } \\
0 \\
\vdots \\
0 \\
0\end{array}$} & \multirow{3}{*}{$\begin{array}{l}\text { Significance } \\
\qquad p<.10\end{array}$} \\
\hline & Caucasian & $\begin{array}{c}\text { Non- } \\
\text { Caucasian }\end{array}$ & $\begin{array}{l}\text { No } \\
\text { Response }\end{array}$ & & & \\
\hline & $N=149$ & $N=24$ & $N=69$ & & & \\
\hline $\begin{array}{l}\text { County Office of Ed. } \\
\text { Workshops }\end{array}$ & 15 & 3 & 8 & 26 & $10.7 \%$ & .694 \\
\hline $\begin{array}{l}\text { Beginning Teacher } \\
\text { Support \& Assessment }\end{array}$ & 15 & 6 & 3 & 24 & $09.9 \%$ & .481 \\
\hline $\begin{array}{l}\text { Online/Distance } \\
\text { Learning }\end{array}$ & 14 & 0 & 5 & 19 & $07.8 \%$ & .388 \\
\hline Other & 12 & 0 & 5 & 17 & $07.0 \%$ & .602 \\
\hline
\end{tabular}

Part Five: Cross Tabulations between Most Valuable Professional Growth Activities and

\section{Demographics}

Section IV of the survey (see Appendix B) asked the respondents to identify the top 3-5 activities they found most professionally valuable, and to indicate which activity proved to be most valuable. Once these activities were identified the numbers from each activity were totaled and the sums were cross tabulated with the ordinal data from the demographic section using a Spearman Correlation $(\not<.10)$ test. This test was run to discover any significant difference between the two sets of data.

The demographic data that were utilized in the cross tabulations included: (a) number of years teaching, (b) number of years in the current job, (c) level of education, (d) type of California teaching credential, (e) the amount of district reimbursement for professional growth expenses, (f) the number of high school instrumental teachers in the district, (g) the size of school, (h) the school location, (i) the number of students in the instrumental music program at each site, $(j)$ sex, and $(k)$ race of the respondents. 
These cross tabulations were analyzed in order to determine differences between selection in respondents most valuable professional growth activities and demographic categories to determine significant differences among the preferences of any of the subgroups.

If the data in any of the sub-groups differ significantly as a result of the Spearman rho test (which shows the probability that there is a variation among one or more of the subgroups within the professional growth activity) then further analysis was performed. Additional analysis determined the extent to which the expected number of responses fell above or below the actual number for the sub-group.

For example, if an activity has less than .10 in the probability column following the Spearman rho cross tabulations, then a significant difference exists in one of the sub-groups within that activity. Taking the total number of responses from each sub-group and multiplying that number by the total percentage in the activity row results in datum that represents the expected number of responses within each sub-group. These findings are expressed in percentages in the analysis of the data in each table.

Each table is organized by listing the activities in descending order based upon the total percentage of responses supplied by the survey population. The total population average level of each activity is indicated in the column with the heading " $\%$ of Total."

In all of the following cross-tabulation tables, the terms "Activity," "Category," "SubCategory," "Sub-Groups," and "Groupings" are used according to the explanations and definitions presented in Chapter Three of this study.

The data in Tables 34 through 44 also indicate the total number of selections made by the survey population in each activity. This number is found in the column labeled "Total 
$\mathrm{N}=242$ " and further reinforces the mean score rankings of the survey population in Table 22 and the most valuable activity rankings in Table 45.

The survey respondents chose four activities (see Tables 34 through 44) at a rate of $50 \%$ or more as their most valuable professional activities. These activities included (a) Music Conferences (74.7\%), (b) Observing Other Rehearsals (73.1\%), (c) Hosting a Guest Teacher or Clinician (66.9\%), and (d) Music Workshops (52\%).

Two other activities rated moderately high on the respondent's list. These activities included Attendance at Concerts (48.7\%) and New Music Reading Sessions (38.8\%).

At the bottom of the scale, and selected by less than $10 \%$ of the survey population, are twelve activities. These activities are (a) Educational Research, (b) Peer Mentoring Activities, (c) Service as a Mentor Teacher, (d) Curriculum Development Meetings, (e) other activities such as performing as a musician, festival participation, conducting honor groups, clinics with university ensembles, and serving on education committees, (f) Beginning Teacher Support and Assessment, (g) District Sponsored Workshops, (h) Online or Distance Learning, (i) Non-Music Conferences, (j) County Office of Education Workshops, (k) OnCampus Inservice, and (1) Non-Music Workshops.

It must be noted that certain activities are targeted towards sub-groups within the survey population, thus limiting rates of participation. These activities include Beginning Teacher Support and Assessment activities and possibly Service as a Mentor Teacher and Being a Guest Teacher or Clinician.

Table 34 indicates cross tabulations between the most valuable professional growth activities identified by the respondents with the survey population's total number of years taught. The data indicate that there are two activities in which the selections of the respondents vary significantly $(p<.10)$ from the average according to the number of years 
taught. These activities are (a) Attendance at Concerts and (b) taking Additional College Coursework.

Respondents selected Attendance at Concerts as a most valuable activity by $48.7 \%$. However, teachers with five years or less of teaching and those with 11 or more years of teaching chose this activity less than the total average, while teachers with $6-10$ years of teaching chose Concert Attendance as a most valuable activity $18.6 \%$ more than the average of the respondents.

Table 34

Most Valuable Professional Growth Activities by Number of Years Teaching

\begin{tabular}{|c|c|c|c|c|c|c|c|c|}
\hline \multirow[b]{3}{*}{ Activity } & \multicolumn{5}{|c|}{ Number of Years Teaching } & \multirow{3}{*}{$\begin{array}{l}\text { Total } \\
N=242\end{array}$} & \multirow{3}{*}{$\begin{array}{l}\text { تٓ } \\
0 \\
0 \\
0 \\
0\end{array}$} & \multirow{3}{*}{$\begin{array}{l}\text { Sig. } \\
p<.10\end{array}$} \\
\hline & $0-2$ & $3-5$ & $6-10$ & $11-14$ & $15+$ & & & \\
\hline & $\mathrm{N}=38$ & $N=31$ & $N=46$ & $N=32$ & $N=95$ & & & \\
\hline Music Conferences & 30 & 26 & 27 & 28 & 70 & 181 & $74.7 \%$ & .105 \\
\hline $\begin{array}{l}\text { Observing Other } \\
\text { Rehearsals }\end{array}$ & 32 & 25 & 33 & 21 & 66 & 177 & $73.1 \%$ & .584 \\
\hline $\begin{array}{l}\text { Hosting a Guest } \\
\text { Teacher/Clinician }\end{array}$ & 23 & 22 & 35 & 26 & 56 & 162 & $66.9 \%$ & .939 \\
\hline Music Workshops & 18 & 18 & 21 & 20 & 49 & 126 & $52.0 \%$ & .812 \\
\hline $\begin{array}{l}\text { Attendance at } \\
\text { Concerts }\end{array}$ & 17 & 12 & 31 & 13 & 45 & 118 & $48.7 \%$ & .003 \\
\hline $\begin{array}{l}\text { New Music Reading } \\
\text { Sessions }\end{array}$ & 9 & 10 & 17 & 14 & 44 & 94 & $38.8 \%$ & .518 \\
\hline $\begin{array}{l}\text { Additional College } \\
\text { Coursework }\end{array}$ & 9 & 10 & 16 & 11 & 20 & 66 & $27.2 \%$ & .061 \\
\hline $\begin{array}{l}\text { Being a Guest } \\
\text { Teacher/Clinician }\end{array}$ & 4 & 5 & 7 & 5 & 27 & 48 & $19.8 \%$ & .173 \\
\hline $\begin{array}{l}\text { Service in a Music } \\
\text { Organization }\end{array}$ & 5 & 3 & 6 & 4 & 21 & 39 & $16.1 \%$ & .280 \\
\hline Educational Research & 4 & 3 & 5 & 0 & 10 & 22 & $09.0 \%$ & .296 \\
\hline
\end{tabular}




\begin{tabular}{|c|c|c|c|c|c|c|c|c|}
\hline \multirow[b]{2}{*}{ Activity } & \multicolumn{5}{|c|}{ Number of Years Teaching } & \multirow[b]{2}{*}{$\begin{array}{c}\text { Total } \\
N=242\end{array}$} & \multirow{2}{*}{ 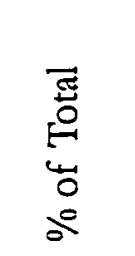 } & \multirow[b]{2}{*}{$\begin{array}{c}\text { Sig. } \\
p<.10\end{array}$} \\
\hline & $\begin{array}{c}0-2 \\
N=38\end{array}$ & $\begin{array}{c}3-5 \\
N=31\end{array}$ & $\begin{array}{c}6-10 \\
N=46\end{array}$ & $\begin{array}{l}11-14 \\
N=32\end{array}$ & $\begin{array}{c}15+ \\
N=95\end{array}$ & & & \\
\hline $\begin{array}{l}\text { Peer Mentoring } \\
\text { Activities }\end{array}$ & 6 & 4 & 3 & 1 & 7 & 21 & $08.6 \%$ & .103 \\
\hline $\begin{array}{l}\text { Service as a Mentor } \\
\text { Teacher }\end{array}$ & 1 & 1 & 2 & 2 & 7 & 13 & $05.3 \%$ & .864 \\
\hline $\begin{array}{l}\text { Curriculum } \\
\text { Development } \\
\text { Meetings }\end{array}$ & 2 & 2 & 2 & 1 & 6 & 13 & $05.3 \%$ & .137 \\
\hline Other $^{2}$ & 0 & 1 & 1 & 0 & 4 & 6 & $02.4 \%$ & .792 \\
\hline $\begin{array}{l}\text { Beginning Teacher } \\
\text { Support \& Assessment }\end{array}$ & 4 & 2 & 0 & 0 & 0 & 6 & $02.4 \%$ & .841 \\
\hline $\begin{array}{l}\text { District Sponsored } \\
\text { Workshops }\end{array}$ & 0 & 1 & 2 & 0 & 2 & 5 & $02.0 \%$ & .630 \\
\hline $\begin{array}{l}\text { Online/Distance } \\
\text { Learning }\end{array}$ & 1 & 0 & 0 & 0 & 3 & 4 & $01.6 \%$ & $\ldots$ \\
\hline $\begin{array}{l}\text { Non-Music } \\
\text { Conferences }\end{array}$ & 0 & 0 & 1 & 0 & 2 & 3 & $01.2 \%$ & $\ldots b$ \\
\hline $\begin{array}{l}\text { County Office of Ed. } \\
\text { Workshops }\end{array}$ & 0 & 1 & 0 & 0 & 1 & 2 & $00.8 \%$ & $\ldots \mathrm{b}$ \\
\hline On-Campus Inservice & 1 & 0 & 0 & 0 & 1 & 2 & $00.8 \%$ & $\ldots b$ \\
\hline $\begin{array}{l}\text { Non-Music } \\
\text { Workshops }\end{array}$ & 0 & 0 & 0 & 0 & 2 & 2 & $00.8 \%$ & $--b$ \\
\hline
\end{tabular}

'This includes activities such as performing as a musician, festival participation, conducting honor groups, clinics with university ensembles, and serving on education committees.

Tables 34 through 44 will use these same designations for the Other activity.

${ }^{\mathrm{b}}$ Sample size was $<5$

Based upon the number of years teaching, 27.2\% of the respondents chose Additional College Coursework as one of their top activities. Yet teachers with 0-2 years of teaching 
and teachers with 15 or more years of teacher chose this activity less than the average of the survey population, and teachers with 3-14 years of experience chose Additional College Coursework more than the average.

While the data from Music Conferences (Table 34) does not indicate a significant difference among the sub-groups it is nearly significant $(p=.105)$. Teachers with 6-10 years of teaching experience selected Music Conferences as a most valuable activity $15.3 \%$ higher than the average of the survey population.

Table 35

Most Valuable Professional Growth Activities by Years in Current Job

\begin{tabular}{|c|c|c|c|c|c|c|c|c|}
\hline \multirow{3}{*}{ Activity } & \multicolumn{5}{|c|}{ Number of Years in Current Job } & \multirow{3}{*}{$\begin{array}{c}\text { Total } \\
\mathrm{N}=242\end{array}$} & \multirow{3}{*}{ 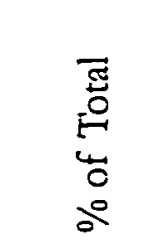 } & \multirow{3}{*}{$\begin{array}{l}\text { Sig. } \\
p<.10\end{array}$} \\
\hline & $0-2$ & $3-5$ & $6-10$ & $11-14$ & $15+$ & & & \\
\hline & $N=63$ & $\mathrm{~N}=54$ & $N=61$ & $N=25$ & $\mathrm{~N}=39$ & & & \\
\hline Music Conferences & 47 & 36 & 45 & 24 & 29 & 181 & $74.7 \%$ & .157 \\
\hline $\begin{array}{l}\text { Observing Other } \\
\text { Rehearsals }\end{array}$ & 53 & 40 & 46 & 13 & 25 & 177 & $73.1 \%$ & .592 \\
\hline $\begin{array}{l}\text { Hosting a Guest } \\
\text { Teacher/Clinician }\end{array}$ & 36 & 42 & 45 & 15 & 24 & 162 & $66.9 \%$ & .663 \\
\hline Music Workshops & 35 & 26 & 26 & 17 & 22 & 126 & $52.0 \%$ & .801 \\
\hline $\begin{array}{l}\text { Attendance at } \\
\text { Concerts }\end{array}$ & 30 & 32 & 28 & 9 & 19 & 118 & $48.7 \%$ & .003 \\
\hline $\begin{array}{l}\text { New Music Reading } \\
\text { Sessions }\end{array}$ & 17 & 19 & 26 & 9 & 23 & 94 & $38.8 \%$ & .490 \\
\hline $\begin{array}{l}\text { Additional College } \\
\text { Coursework }\end{array}$ & 18 & 16 & 19 & 8 & 5 & 66 & $27.2 \%$ & .002 \\
\hline $\begin{array}{l}\text { Being a Guest } \\
\text { Teacher/Clinician }\end{array}$ & 10 & 11 & 15 & 5 & 7 & 48 & $19.8 \%$ & .774 \\
\hline $\begin{array}{l}\text { Service in a Music } \\
\text { Organization }\end{array}$ & 8 & 4 & 13 & 4 & 10 & 39 & $16.1 \%$ & .217 \\
\hline Educational Research & 8 & 7 & 2 & 1 & 4 & 22 & $09.0 \%$ & .816 \\
\hline
\end{tabular}




\begin{tabular}{|c|c|c|c|c|c|c|c|c|}
\hline \multirow{3}{*}{ Activity } & \multicolumn{5}{|c|}{ Number of Years in Current Job } & \multirow{3}{*}{$\begin{array}{c}\text { Total } \\
N=242\end{array}$} & \multirow{3}{*}{ 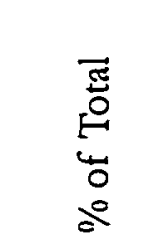 } & \multirow{3}{*}{$\begin{array}{c}\text { Sig. } \\
p<.10\end{array}$} \\
\hline & $0-2$ & $3-5$ & $6-10$ & $11-14$ & $15+$ & & & \\
\hline & $N=63$ & $N=54$ & $N=61$ & $N=25$ & $\mathrm{~N}=39$ & & & \\
\hline $\begin{array}{l}\text { Peer Mentoring } \\
\text { Activities }\end{array}$ & 9 & 2 & 3 & 2 & 5 & 21 & $08.6 \%$ & .303 \\
\hline $\begin{array}{l}\text { Service as a Mentor } \\
\text { Teacher }\end{array}$ & 1 & 0 & 5 & 3 & 4 & 13 & $05.3 \%$ & .835 \\
\hline $\begin{array}{l}\text { Curriculum } \\
\text { Development } \\
\text { Meetings }\end{array}$ & 6 & 2 & 2 & 2 & 1 & 13 & $05.3 \%$ & .764 \\
\hline $\begin{array}{l}\text { Beginning Teacher } \\
\text { Support \& } \\
\text { Assessment }\end{array}$ & 4 & 2 & 0 & 0 & 0 & 6 & $02.4 \%$ & .841 \\
\hline Other & 0 & 3 & 0 & 0 & 3 & 6 & $02.4 \%$ & .850 \\
\hline $\begin{array}{l}\text { District Sponsored } \\
\text { Workshops }\end{array}$ & 2 & 3 & 0 & 0 & 0 & 5 & $02.0 \%$ & .596 \\
\hline $\begin{array}{l}\text { Online/Distance } \\
\text { Learning }\end{array}$ & 1 & 1 & 0 & 0 & 2 & 4 & $01.6 \%$ & $-a^{a}$ \\
\hline $\begin{array}{l}\text { Non-Music } \\
\text { Conferences }\end{array}$ & 1 & 0 & 0 & 1 & 1 & 3 & $01.2 \%$ & $\ldots a$ \\
\hline On-Campus Inservice & 2 & 0 & 0 & 0 & 0 & 2 & $00.8 \%$ & $\ldots$ \\
\hline $\begin{array}{l}\text { Non-Music } \\
\text { Workshops }\end{array}$ & 0 & 0 & 0 & 1 & 1 & 2 & $00.8 \%$ & --- $a$ \\
\hline $\begin{array}{l}\text { County Office of Ed. } \\
\text { Workshops }\end{array}$ & 0 & 1 & 0 & 0 & 1 & 2 & $00.8 \%$ & -a a \\
\hline
\end{tabular}

${ }^{a}$ Sample size was $<5$

Table 35 offers cross tabulations between the most valuable professional growth activities identified by the respondents with the survey population's total number of years in their current job. The data indicate that there are two activities in which the selections of the respondents vary significantly $(\phi<.10)$ from the average according to the number of years in 
the current job. These activities are (a) Attendance at Concerts and (b) taking Additional College Coursework.

Respondents selected Attendance at Concerts by $48.7 \%$ as one of the top activities while teachers with $0-2$ years and $6-10$ years in their current job chose this activity less than the rest of the respondents. Teachers with 3-5 years and 11-14 years in their job chose this activity as most valuable more than the average of the respondents.

Teachers in their jobs 15 years or more chose Additional College Coursework as a valuable activity much less than the average of the respondents while less experienced teachers chose coursework options more frequently. This discrepancy is probably due to the fact that taking Additional College Courses is only valuable to those teachers who are using the units earned for advancement on the salary scale or who may be seeking counseling or administrative credentials. Teachers not desiring college credit for salary advancement or clear credential may not find this activity to be as valuable as other activities.

Table 36 presents cross tabulations between the most valuable professional growth activities identified by the respondents with the level of education.

This cross tabulation between the level of education obtained by the survey respondents and their choices of most valuable activities did not produce any significant differences between the respondents and the activities (see Table 36). 
Table 36

Most Valuable Professional Growth Activities by Level of Education

\begin{tabular}{|c|c|c|c|c|c|c|c|c|c|}
\hline \multirow[b]{2}{*}{ Activity } & \multicolumn{6}{|c|}{ Level of Education } & \multirow[b]{2}{*}{$\begin{array}{c}\text { 吾 } \\
N=242\end{array}$} & \multirow[b]{2}{*}{$\begin{array}{l}\text { 푱 } \\
\text { 峲 } \\
0 \\
0\end{array}$} & \multirow[b]{2}{*}{$\begin{array}{l}\text { Sig. } \\
p<.10\end{array}$} \\
\hline & 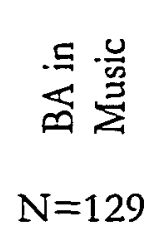 & 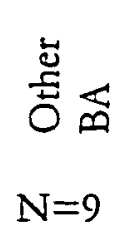 & $\begin{array}{l}\stackrel{S}{S} \stackrel{0}{\mathscr{N}} \\
N=74\end{array}$ & $\begin{array}{l}\stackrel{\vec{\Xi}}{\Xi} \ \\
N=25\end{array}$ & 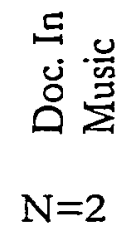 & 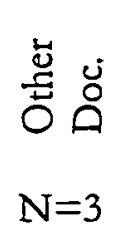 & & & \\
\hline $\begin{array}{l}\text { Music } \\
\text { Conferences }\end{array}$ & 99 & 7 & 53 & 17 & 2 & 2 & 181 & $74.7 \%$ & .411 \\
\hline $\begin{array}{l}\text { Observing Other } \\
\text { Rehearsals }\end{array}$ & 98 & 5 & 50 & 21 & 1 & 2 & 177 & $73.1 \%$ & .467 \\
\hline $\begin{array}{l}\text { Hosting a Guest } \\
\text { Teacher/Clinician }\end{array}$ & 83 & 5 & 52 & 18 & 2 & 2 & 162 & $66.9 \%$ & .491 \\
\hline Music Workshops & 66 & 5 & 41 & 11 & 2 & 1 & 126 & $52.0 \%$ & .558 \\
\hline $\begin{array}{l}\text { Attendance at } \\
\text { Concerts }\end{array}$ & 66 & 4 & 31 & 13 & 2 & 2 & 118 & $48.7 \%$ & .634 \\
\hline $\begin{array}{l}\text { New Music } \\
\text { Reading Sessions }\end{array}$ & 46 & 1 & 35 & 11 & 0 & 1 & 94 & $38.8 \%$ & .445 \\
\hline $\begin{array}{l}\text { Additional } \\
\text { College } \\
\text { Coursework }\end{array}$ & 32 & 4 & 23 & 7 & 0 & 0 & 66 & $27.2 \%$ & .216 \\
\hline $\begin{array}{l}\text { Being a Guest } \\
\text { Teacher/Clinician }\end{array}$ & 23 & 2 & 15 & 7 & 0 & 1 & 48 & $19.8 \%$ & .323 \\
\hline $\begin{array}{l}\text { Service in a } \\
\text { Music } \\
\text { Organization }\end{array}$ & 22 & 0 & 13 & 3 & 0 & 1 & 39 & $16.1 \%$ & .540 \\
\hline $\begin{array}{l}\text { Educational } \\
\text { Research }\end{array}$ & 11 & 0 & 7 & 2 & 1 & 1 & 22 & $09.0 \%$ & .780 \\
\hline $\begin{array}{l}\text { Peer Mentoring } \\
\text { Activities }\end{array}$ & 8 & 4 & 8 & 1 & 0 & 0 & 21 & $08.6 \%$ & .899 \\
\hline $\begin{array}{l}\text { Service as a } \\
\text { Mentor Teacher }\end{array}$ & 5 & 0 & 7 & 1 & 0 & 0 & 13 & $05.3 \%$ & .220 \\
\hline $\begin{array}{l}\text { Curriculum } \\
\text { Development } \\
\text { Meetings }\end{array}$ & 8 & 0 & 5 & 0 & 0 & 0 & 13 & $05.3 \%$ & .417 \\
\hline
\end{tabular}




\begin{tabular}{|c|c|c|c|c|c|c|c|c|c|}
\hline Activity & 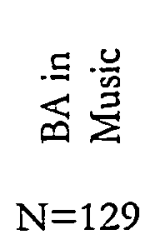 & $\begin{array}{l}\stackrel{\Delta}{ \pm} \\
N=9\end{array}$ & 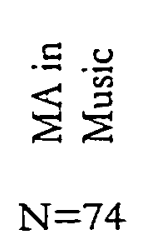 & 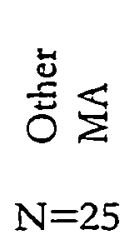 & 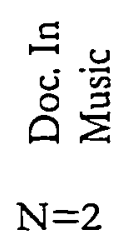 & 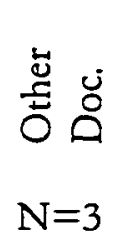 & $\begin{array}{c}\text { 퓽 } \\
N=242\end{array}$ & $\begin{array}{l}\text { 至 } \\
\stackrel{0}{0} \\
\text { 岁 } \\
0\end{array}$ & $\begin{array}{l}\text { Sig. } \\
p<.10\end{array}$ \\
\hline $\begin{array}{l}\text { Beginning } \\
\text { Teacher Support } \\
\text { \& Assessment }\end{array}$ & 5 & 1 & 0 & 0 & 0 & 0 & 6 & $02.4 \%$ & .142 \\
\hline Other & 4 & 1 & 1 & 0 & 0 & 0 & 6 & $02.4 \%$ & .792 \\
\hline $\begin{array}{l}\text { District } \\
\text { Sponsored } \\
\text { Workshops }\end{array}$ & 3 & 0 & 1 & 1 & 0 & 0 & 5 & $02.0 \%$ & .260 \\
\hline $\begin{array}{l}\text { Online/Distance } \\
\text { Learning }\end{array}$ & 1 & 1 & 1 & 1 & 0 & 0 & 4 & $01.6 \%$ & $\ldots a$ \\
\hline $\begin{array}{l}\text { Non-Music } \\
\text { Conferences }\end{array}$ & 2 & 0 & 0 & 1 & 0 & 0 & 3 & $01.2 \%$ & $\ldots$ \\
\hline $\begin{array}{l}\text { On-Campus } \\
\text { Inservice }\end{array}$ & 1 & 0 & 1 & 0 & 0 & 0 & 2 & $00.8 \%$ & $\ldots$ \\
\hline $\begin{array}{l}\text { Non-Music } \\
\text { Workshops }\end{array}$ & 0 & 1 & 1 & 0 & 0 & 0 & 2 & $00.8 \%$ & $\ldots$ \\
\hline $\begin{array}{l}\text { County Office of } \\
\text { Ed. Workshops }\end{array}$ & 0 & 1 & 0 & 1 & 0 & 0 & 2 & $00.8 \%$ & $\ldots$ \\
\hline
\end{tabular}

${ }^{2}$ Sample size was $<5$

Table 37 indicates cross tabulations between the most valuable professional growth activities identified by the respondents with the survey population's type of California teaching credential. The data indicate that there is one activity in which the selections of the respondents vary significantly $(p<.10)$ from the average according to the type of California teaching credential. This activity is Service in a Music Organization. 
Table 37

Most Valuable Professional Growth Activities by Type of California Teaching Credential

\begin{tabular}{|c|c|c|c|c|c|c|c|c|c|}
\hline \multirow[b]{2}{*}{ Activity } & \multicolumn{6}{|c|}{ California Teaching Credential } & \multirow[b]{2}{*}{ 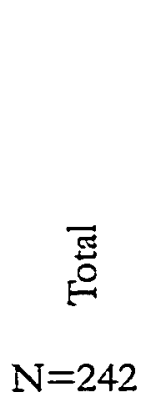 } & \multirow[b]{2}{*}{ 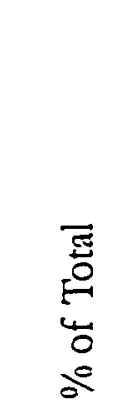 } & \multirow[b]{2}{*}{$\begin{array}{l}\text { Sig. } \\
p<.10\end{array}$} \\
\hline & 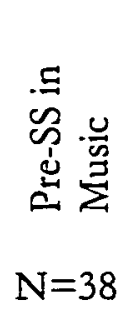 & 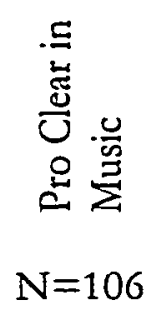 & 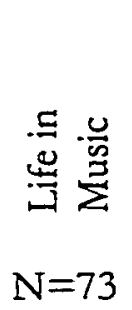 & 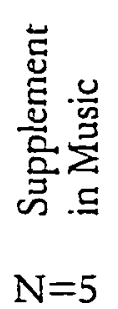 & 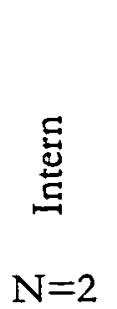 & 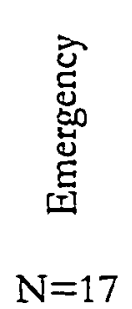 & & & \\
\hline $\begin{array}{l}\text { Music } \\
\text { Conferences }\end{array}$ & 31 & 79 & 53 & 5 & 1 & 12 & 181 & $74.7 \%$ & .478 \\
\hline $\begin{array}{l}\text { Observing Other } \\
\text { Rehearsals }\end{array}$ & 33 & 73 & 53 & 3 & 1 & 14 & 177 & $73.1 \%$ & .829 \\
\hline $\begin{array}{l}\text { Hosting a Guest } \\
\text { Teacher/Clinician }\end{array}$ & 28 & 70 & 51 & 2 & 0 & 11 & 162 & $66.9 \%$ & .925 \\
\hline Music Workshops & 18 & 55 & 37 & 4 & 1 & 11 & 126 & $52.0 \%$ & .264 \\
\hline $\begin{array}{l}\text { Attendance at } \\
\text { Concerts }\end{array}$ & 21 & 55 & 32 & 3 & 0 & 7 & 118 & $48.7 \%$ & .103 \\
\hline $\begin{array}{l}\text { New Music } \\
\text { Reading Sessions }\end{array}$ & 8 & 44 & 46 & 2 & 1 & 3 & 94 & $38.8 \%$ & .466 \\
\hline $\begin{array}{l}\text { Additional } \\
\text { College } \\
\text { Coursework }\end{array}$ & 12 & 37 & 12 & 1 & 0 & 4 & 66 & $27.2 \%$ & .688 \\
\hline $\begin{array}{l}\text { Being a Guest } \\
\text { Teacher/Clinician }\end{array}$ & 5 & 25 & 14 & 0 & 1 & 3 & 48 & $19.8 \%$ & .420 \\
\hline $\begin{array}{l}\text { Service in a } \\
\text { Music } \\
\text { Organization }\end{array}$ & 2 & 17 & 17 & 0 & 0 & 3 & 39 & $16.1 \%$ & .013 \\
\hline $\begin{array}{l}\text { Educational } \\
\text { Research }\end{array}$ & 6 & 6 & 7 & 1 & 0 & 2 & 22 & $09.0 \%$ & .699 \\
\hline $\begin{array}{l}\text { Peer Mentoring } \\
\text { Activities }\end{array}$ & 3 & 7 & 7 & 1 & 0 & 3 & 21 & $08.6 \%$ & .851 \\
\hline $\begin{array}{l}\text { Service as a } \\
\text { Mentor Teacher }\end{array}$ & 0 & 6 & 7 & 0 & 0 & 0 & 13 & $05.3 \%$ & .483 \\
\hline
\end{tabular}




\begin{tabular}{|c|c|c|c|c|c|c|c|c|c|}
\hline \multirow{2}{*}{ Ictivity } & \multicolumn{6}{|c|}{ California Teaching Credential } & \multirow[b]{2}{*}{ 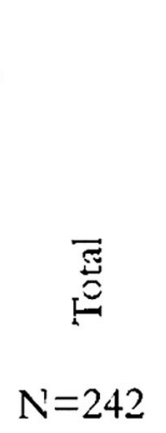 } & \multirow[b]{2}{*}{$\begin{array}{l}\text { 焉 } \\
\vdots \\
\vdots \\
\vdots \\
0 \\
0\end{array}$} & \multirow[b]{2}{*}{$\begin{array}{l}\text { Sig. } \\
p<.10\end{array}$} \\
\hline & 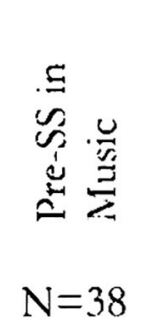 & 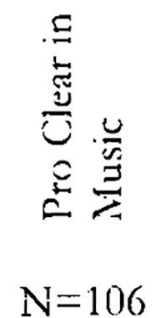 & 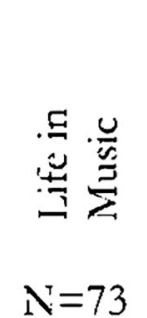 & 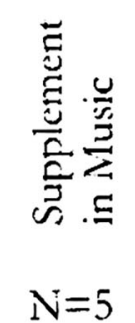 & $\begin{array}{c}\stackrel{\Xi}{\Xi} \\
N=2\end{array}$ & 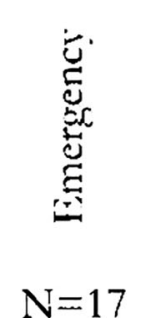 & & & \\
\hline $\begin{array}{l}\text { Curriculum } \\
\text { Development } \\
\text { Afectings }\end{array}$ & 2 & 8 & 3 & 0 & 0 & 0 & 13 & $\left(05.3^{11 / 10}\right.$ & .627 \\
\hline $\begin{array}{l}\text { Becginning } \\
\text { Teacher Support } \\
\& \alpha \text { ssessment }\end{array}$ & 3 & 1 & 0 & 0 & 0 & 2 & 6 & $02.4 \%$ & .649 \\
\hline ()ther & () & 2 & 3 & 0 & 0 & 1 & 6 & $(02.4 \%$ & .321 \\
\hline $\begin{array}{l}\text { District } \\
\text { Sponsored } \\
\text { Workshops }\end{array}$ & 3 & 1 & 1 & 0 & 0 & 0 & 5 & $02.0 \%$ & .841 \\
\hline $\begin{array}{l}\text { ()nline/ } \\
\text { Distance } \\
\text { l.earning }\end{array}$ & 1 & 1 & 2 & 0 & 0 & 0 & 4 & $01.6 \%$ & $---a^{a}$ \\
\hline $\begin{array}{l}\text { Non-Music } \\
\text { Conferences }\end{array}$ & 0 & 2 & 1 & 0 & 0 & 0 & 3 & $01.2 \%$ & $\ldots$ \\
\hline $\begin{array}{l}\text { On-Campus } \\
\text { Inservice }\end{array}$ & 1 & 1 & 0 & 0 & 0 & 0 & 2 & $00.8 \%$ & $---a^{a}$ \\
\hline $\begin{array}{l}\text { Non-Music } \\
\text { W'orkshops }\end{array}$ & 0 & 0 & 2 & 0 & 0 & 0 & 2 & $00.81 \%$ & $\ldots$ \\
\hline $\begin{array}{l}\text { County Office of } \\
\text { Ed. Workshops }\end{array}$ & 0 & 1 & 1 & 0 & 0 & 0 & 2 & $(01.811 \%$ & --.-a \\
\hline
\end{tabular}

"Sample size was $<5$

Service in a Music Organization was chosen by $16.1 \%$ of the survey population as a most valuable professional growth activity. However, teachers holding preliminary and supplemental credentials did not chose Service in a Music (Organization on the same levels as the rest of the respondents. On the other hand, teachers with life credentials selected Service in a Music ()rganization $7.1 \%$ more than the average of the respondents. 
Selection rates for Concert Attendance as a most valuable activity is practically significant $(p=.103)$. Holders of preliminary credentials and clear credentials selected Concert Attendance as a valuable activity more often, while holders of life credentials selected this activity less often.

Table 38 offers cross tabulations between the most valuable professional growth activities identified by the respondents and the survey population's amount of district reimbursement for participation in professional growth activities. The data indicate that there are two activities in which the selections of the respondents vary significantly $(p<.10)$ from the average according to the amount of reimbursement for professional growth expenses. These activities are (a) Music Conferences and (b) taking Additional College Coursework.

Attendance at Music Conferences was selected by $74.7 \%$ of the survey population as one of their most valuable professional growth activities. Yet, teachers who received $\$ 200$ or less or between $\$ 500-999$ attended Music Conferences more than the survey population average. Teachers, who either did not respond, who received between $\$ 200-499$, or who were reimbursed for all of their professional growth expenses chose Music Conferences as their most valuable experience less than the survey population average.

Taking Additional College or University Coursework was selected by $27.2 \%$ of the respondents as one of their most valued professional growth activities. Teachers who received no reimbursement and teachers who were reimbursed for all of their professional growth expenses took additional college courses at levels slightly more than the survey population average. On the other hand, teachers who received between $\$ 200-\$ 999$ selected College and University Coursework slightly less than the average of the respondents as a most valuable activity. 
With exceptions as noted above, teachers who received no reimbursement for professional growth expenses choose all of the activities as their most valuable on the same ratio as the rest of the survey population.

Table 38

Most Valuable Professional Growth Activities by Amount of District Reimbursement

Amount of District Reimbursement

\begin{tabular}{|c|c|c|c|c|c|c|c|c|}
\hline 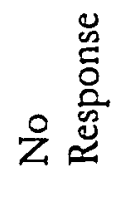 & $\begin{array}{l}\text { ¿ } \\
\text { Z }\end{array}$ & 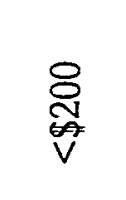 & 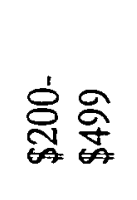 & 它 & $\stackrel{\oplus}{\rightleftarrows}$ & 吾 & $\begin{array}{l}\text { 吾 } \\
\text { 恶 }\end{array}$ & Sig. \\
\hline $\mathrm{N}=8$ & $\mathrm{~N}=78$ & $\mathrm{~N}=62$ & $N=61$ & $N=10$ & $\mathrm{~N}=23$ & $N=242$ & 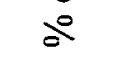 & $p<.10$ \\
\hline 5 & 58 & 50 & 45 & 9 & 14 & 181 & $\%$ & .011 \\
\hline
\end{tabular}

Music

$5 \quad 56 \quad 49$

$49 \quad 41$

$10 \quad 16$

177

$73.1 \%$

.841

Rehearsals

Hosting a Gues

848

43

44

$5 \quad 14$

162

$66.9 \%$

.485

Teacher/Clinician

Music Workshops

$3 \quad 44 \quad 30$

32

$\begin{array}{lll}5 & 12 & 126\end{array}$

$52.0 \% \quad .625$

Attendance at

$5 \quad 32$

29

33

7

12

118

$48.7 \% \quad .747$

Concerts

New Music

$2 \quad 32$

$24 \quad 25$

2

9

94

$38.8 \%$

.924

Reading Sessions

Additional

22

17

16

2

$7 \quad 66$

$27.2 \% \quad .047$

College

Coursework

Being a Guest

$1 \quad 17$

13

11

2

4

48

Teacher/Clinician

Service in a

115

$7 \quad 11$

2

3

39

$16.1 \% \quad .806$

Music

Organization

Educational

Research

$0 \quad 5$

5

8

2

2

22

$09.0 \% \quad .884$ 


\begin{tabular}{|c|c|c|c|c|c|c|c|c|c|}
\hline \multirow[b]{2}{*}{ Activity } & \multicolumn{6}{|c|}{ Amount of District Reimbursement } & \multirow[b]{2}{*}{$\begin{array}{l}\mathrm{N}=242 \\
\stackrel{\Xi}{0}\end{array}$} & \multirow[b]{2}{*}{$\begin{array}{l}\text { 푱 } \\
\stackrel{0}{0} \\
0 \\
0 \\
0\end{array}$} & \multirow[b]{2}{*}{$\begin{array}{l}\text { Sig. } \\
p<.10\end{array}$} \\
\hline & 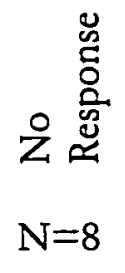 & $\begin{array}{c}\stackrel{0}{Z} \\
N=78\end{array}$ & 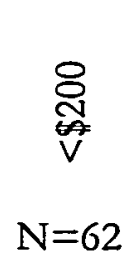 & 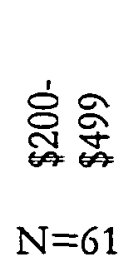 & 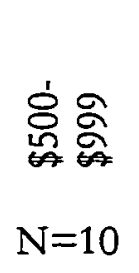 & $\stackrel{\aleph}{\equiv}$ & & & \\
\hline $\begin{array}{l}\text { Peer Mentoring } \\
\text { Activities }\end{array}$ & 0 & 7 & 6 & 5 & 1 & 2 & 21 & $08.6 \%$ & .941 \\
\hline $\begin{array}{l}\text { Service as a } \\
\text { Mentor Teacher }\end{array}$ & 0 & 4 & 5 & 3 & 0 & 1 & 13 & $05.3 \%$ & .996 \\
\hline $\begin{array}{l}\text { Curriculum } \\
\text { Development } \\
\text { Meetings }\end{array}$ & 1 & 4 & 2 & 3 & 0 & 3 & 13 & $05.3 \%$ & .915 \\
\hline $\begin{array}{l}\text { Beginning } \\
\text { Teacher Support } \\
\text { \& Assessment }\end{array}$ & 1 & 3 & 1 & 1 & 0 & 0 & 6 & $02.4 \%$ & .464 \\
\hline Other & 1 & 3 & 1 & 1 & 0 & 0 & 6 & $02.4 \%$ & .131 \\
\hline $\begin{array}{l}\text { District } \\
\text { Sponsored } \\
\text { Workshops }\end{array}$ & 1 & 2 & 1 & 1 & 0 & 0 & 5 & $02.0 \%$ & .640 \\
\hline $\begin{array}{l}\text { Online/Distance } \\
\text { Learning }\end{array}$ & 1 & 1 & 1 & 0 & 0 & 1 & 4 & $01.6 \%$ & $\ldots$ \\
\hline $\begin{array}{l}\text { Non-Music } \\
\text { Conferences }\end{array}$ & 0 & 1 & 2 & 0 & 0 & 0 & 3 & $01.2 \%$ & $\ldots a$ \\
\hline $\begin{array}{l}\text { On-Campus } \\
\text { Inservice }\end{array}$ & 0 & 1 & 1 & 0 & 0 & 0 & 2 & $00.8 \%$ & $\ldots$ \\
\hline $\begin{array}{l}\text { Non-Music } \\
\text { Workshops }\end{array}$ & 0 & 0 & 2 & 0 & 0 & & 2 & $00.8 \%$ & $\ldots$ \\
\hline $\begin{array}{l}\text { County Office of } \\
\text { Ed. Workshops }\end{array}$ & 0 & 1 & 0 & 0 & 0 & 1 & 2 & $00.8 \%$ & $\ldots$ \\
\hline
\end{tabular}

${ }^{2}$ Sample size was $<5$ 
Table 39

Most Valuable Professional Growth Activities by the Number of High School Instrumental Music Teachers in the District

\begin{tabular}{|c|c|c|c|c|c|c|c|c|c|}
\hline \multirow{3}{*}{ Activity } & \multicolumn{6}{|c|}{ HS Instrumental Music Teachers in the District } & \multirow{3}{*}{$\begin{array}{c}\text { 롱 } \\
N=242\end{array}$} & \multirow{3}{*}{$\begin{array}{l}\text { Ẽ } \\
\text { 总 } \\
0 \\
0\end{array}$} & \multirow{3}{*}{ 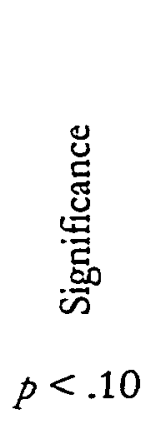 } \\
\hline & 1 & $\stackrel{+}{\stackrel{N}{*}}$ & $\underset{0}{a}$ & $\begin{array}{l}2 \\
2 \\
0\end{array}$ & 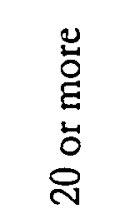 & 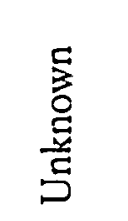 & & & \\
\hline & $N=48$ & $N=62$ & $N=58$ & $N=35$ & $N=35$ & $N=4$ & & & \\
\hline $\begin{array}{l}\text { Music } \\
\text { Conferences }\end{array}$ & 40 & 47 & 46 & 23 & 22 & 3 & 181 & $74.7 \%$ & .098 \\
\hline $\begin{array}{l}\text { Observing } \\
\text { Other Rehearsals }\end{array}$ & 34 & 47 & 44 & 26 & 23 & 3 & 177 & $73.1 \%$ & .016 \\
\hline $\begin{array}{l}\text { Hosting a Guest } \\
\text { Teacher/Clinician }\end{array}$ & 29 & 39 & 41 & 25 & 25 & 3 & 162 & $66.9 \%$ & .980 \\
\hline $\begin{array}{l}\text { Music } \\
\text { Workshops }\end{array}$ & 25 & 33 & 31 & 18 & 15 & 4 & 126 & $52.0 \%$ & .832 \\
\hline $\begin{array}{l}\text { Attendance at } \\
\text { Concerts }\end{array}$ & 21 & 28 & 28 & 21 & 18 & 2 & 118 & $48.7 \%$ & .767 \\
\hline $\begin{array}{l}\text { New Music } \\
\text { Reading Sessions }\end{array}$ & 21 & 27 & 23 & 10 & 12 & 1 & 94 & $38.8 \%$ & .609 \\
\hline $\begin{array}{l}\text { Additional } \\
\text { College } \\
\text { Coursework }\end{array}$ & 18 & 12 & 20 & 6 & 9 & 1 & 66 & $27.2 \%$ & .805 \\
\hline $\begin{array}{l}\text { Being a Guest } \\
\text { Teacher/Clinician }\end{array}$ & 4 & 8 & 13 & 11 & 11 & 1 & 48 & $19.8 \%$ & .833 \\
\hline $\begin{array}{l}\text { Service in a } \\
\text { Music } \\
\text { Organization }\end{array}$ & 9 & 14 & 6 & 5 & 5 & 0 & 39 & $16.1 \%$ & .874 \\
\hline $\begin{array}{l}\text { Educational } \\
\text { Research }\end{array}$ & 3 & 7 & 6 & 2 & 3 & 1 & 22 & $09.0 \%$ & .201 \\
\hline $\begin{array}{l}\text { Peer Mentoring } \\
\text { Activities }\end{array}$ & 3 & 5 & 3 & 6 & 4 & 21 & 21 & $08.6 \%$ & .460 \\
\hline
\end{tabular}


HS Instrumental Music Teachers in the District

\begin{tabular}{|c|c|c|c|c|c|c|c|c|c|}
\hline \multirow[b]{2}{*}{ Activity } & 1 & $\begin{array}{c}+ \\
\stackrel{\Delta}{v} \\
\sim\end{array}$ & $\underset{\text { in }}{a}$ & $\stackrel{2}{0}$ & 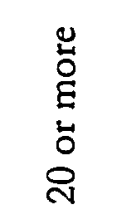 & 志 & 嵒 & 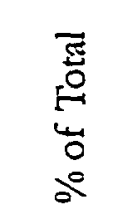 & 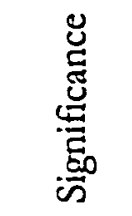 \\
\hline & $N=48$ & $N=62$ & $N=58$ & $\mathrm{~N}=35$ & $\mathrm{~N}=35$ & $N=4$ & $N=242$ & & $p<.10$ \\
\hline $\begin{array}{l}\text { Service as a } \\
\text { Mentor Teacher }\end{array}$ & 2 & 1 & 4 & 3 & 2 & 1 & 13 & $05.3 \%$ & .218 \\
\hline $\begin{array}{l}\text { Curriculum } \\
\text { Development } \\
\text { Meetings }\end{array}$ & 2 & 3 & 3 & 3 & 2 & 0 & 13 & $05.3 \%$ & .151 \\
\hline $\begin{array}{l}\text { Beginning } \\
\text { Teacher Support } \\
\text { \& Assessment }\end{array}$ & 1 & 2 & 0 & 0 & 3 & 0 & 6 & $02.4 \%$ & .456 \\
\hline Other & 1 & 3 & 1 & 1 & 0 & 0 & 6 & $02.4 \%$ & .906 \\
\hline $\begin{array}{l}\text { District } \\
\text { Sponsored } \\
\text { Workshops }\end{array}$ & 1 & 0 & 1 & 1 & 1 & 2 & 5 & $02.0 \%$ & .199 \\
\hline $\begin{array}{l}\text { Online/Distance } \\
\text { Learning }\end{array}$ & 2 & 1 & 1 & 0 & 0 & 0 & 4 & $01.6 \%$ & --- a \\
\hline $\begin{array}{l}\text { Non-Music } \\
\text { Conferences }\end{array}$ & 0 & 1 & 0 & 1 & 1 & 0 & 3 & $01.2 \%$ & $\ldots a$ \\
\hline $\begin{array}{l}\text { On-Campus } \\
\text { Inservice }\end{array}$ & 0 & 0 & 0 & 1 & 1 & 0 & 2 & $00.8 \%$ & $\ldots a$ \\
\hline $\begin{array}{l}\text { Non-Music } \\
\text { Workshops }\end{array}$ & 1 & 0 & 1 & 0 & 0 & 0 & 2 & $00.8 \%$ & $\ldots a$ \\
\hline $\begin{array}{l}\text { County Office of } \\
\text { Ed. Workshops }\end{array}$ & 0 & 1 & 0 & 0 & 1 & 0 & 2 & $00.8 \%$ & $\ldots a$ \\
\hline
\end{tabular}

${ }^{2}$ Sample size was $<5$

Table 39 shows cross tabulations between the most valuable professional growth activities identified by the respondents with the survey population's total number of high school instrumental teachers in the district. The data indicate that there are two activities in which the selections of the respondents vary significantly $(p<.10)$ from the average 
according to the number of high school instrumental teachers in the respondent's districts. These activities are (a) Music Conferences and (b) Observing Other Rehearsals.

Music Conferences was chosen by $74.7 \%$ of the survey population as one of their most valuable professional growth activities. Yet teachers who had less than 10 fellow music teachers in the district choose Music Conferences more often than the rest of the respondents. In contrast, teachers who taught in districts with 10 or more fellow music teachers choose Music Conferences less as a most valuable activity than the rest of the survey population.

Observing Rehearsals was selected by $73.1 \%$ of the high school instrumental music teachers. However, teachers with only one music teacher in the district, and districts with more than 20 chose Observing Rehearsals less than the rest of the group. Teacher with 2-9 instrumental music teachers in the district chose Observing Rehearsals more than the average of the group.

Table 40 illustrates cross tabulations between the most valuable professional growth activities identified by the respondents with the survey population's size of school. The data indicate that there are two activities in which the selections of the respondents vary significantly $(p<.10)$ from the average according to the total school population. These activities are (a) Curriculum Development Meetings and (b) Other activities such as performing as a musician, festival participation, conducting honor groups, clinics with university ensembles, and serving on education committees.

Only 5.3\% choose Curriculum Development Meetings as a most valuable activity, there was a significant difference in the data between the group average and four of the subgroups. Teachers who taught at schools with populations of 1500 to 2499 did not chose Curriculum Development as a valuable activity as often as the rest of the group. And 
teachers with school populations from 1000 to 1499 and more than 2500 indicated

Curriculum Development as one of their most valuable more often than the group average.

Table 40

Most Valuable Professional Growth Activities by School Size

\begin{tabular}{|c|c|c|c|c|c|c|c|c|c|}
\hline \multirow[b]{3}{*}{ Activity } & \multicolumn{6}{|c|}{ School Size } & \multirow{3}{*}{$\begin{array}{c}\text { 퓽 } \\
N=241\end{array}$} & \multirow{3}{*}{ 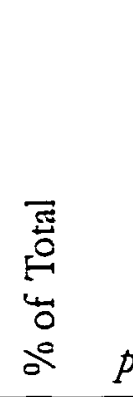 } & \multirow{3}{*}{ 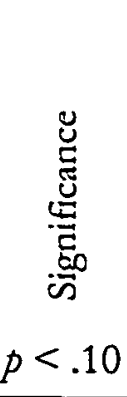 } \\
\hline & হ & $\begin{array}{l}\text { ล } \\
\text { ̊ } \\
8 \\
8\end{array}$ & $\begin{array}{l}\stackrel{g}{+} \\
8 \\
8 \\
8\end{array}$ & $\begin{array}{l}\stackrel{2}{\Xi} \\
\stackrel{8}{8} \\
\stackrel{8}{6}\end{array}$ & 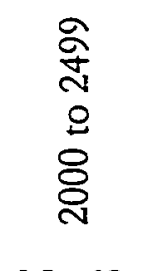 & 官 & & & \\
\hline & $N=16$ & $N=18$ & $N=31$ & $\mathrm{~N}=53$ & $N=62$ & $\mathrm{~N}=61$ & & & \\
\hline $\begin{array}{l}\text { Music } \\
\text { Conferences }\end{array}$ & 13 & 12 & 24 & 39 & 51 & 42 & 181 & $74.7 \%$ & .825 \\
\hline $\begin{array}{l}\text { Observing } \\
\text { Other Rehearsals }\end{array}$ & 13 & 12 & 22 & 38 & 47 & 44 & 177 & $73.1 \%$ & .533 \\
\hline $\begin{array}{l}\text { Hosting a Guest } \\
\text { Teacher/Clinician }\end{array}$ & 10 & 9 & 18 & 37 & 46 & 41 & 162 & $66.9 \%$ & .141 \\
\hline $\begin{array}{l}\text { Music } \\
\text { Workshops }\end{array}$ & 9 & 6 & 19 & 23 & 34 & 35 & 126 & $52.0 \%$ & .254 \\
\hline $\begin{array}{l}\text { Attendance at } \\
\text { Concerts }\end{array}$ & 5 & 8 & 15 & 30 & 26 & 33 & 118 & $48.7 \%$ & .944 \\
\hline $\begin{array}{l}\text { New Music } \\
\text { Reading Sessions }\end{array}$ & 5 & 6 & 18 & 20 & 20 & 25 & 94 & $38.8 \%$ & .666 \\
\hline $\begin{array}{l}\text { Additional } \\
\text { College } \\
\text { Coursework }\end{array}$ & 7 & 5 & 6 & 18 & 13 & 17 & 66 & $27.2 \%$ & .196 \\
\hline $\begin{array}{l}\text { Being a Guest } \\
\text { Teacher/Clinician }\end{array}$ & 1 & 1 & 6 & 12 & 14 & 14 & 48 & $19.8 \%$ & .298 \\
\hline $\begin{array}{l}\text { Service in a Music } \\
\text { Organization }\end{array}$ & 3 & 2 & 1 & 13 & 11 & 9 & 39 & $16.1 \%$ & .296 \\
\hline $\begin{array}{l}\text { Educational } \\
\text { Research }\end{array}$ & 0 & 2 & 1 & 11 & 3 & 5 & 22 & $09.0 \%$ & .867 \\
\hline $\begin{array}{l}\text { Peer Mentoring } \\
\text { Activities }\end{array}$ & 4 & 1 & 3 & 3 & 7 & 3 & 21 & $08.6 \%$ & .464 \\
\hline
\end{tabular}




\begin{tabular}{|c|c|c|c|c|c|c|c|c|c|}
\hline \multirow[b]{3}{*}{ Activity } & \multicolumn{6}{|c|}{ School Size } & \multirow{3}{*}{$\begin{array}{l}\text { Еँ } \\
N=241\end{array}$} & \multirow{3}{*}{$\begin{array}{l}\text { 焉 } \\
\stackrel{0}{0} \\
0 \\
0\end{array}$} & \multirow{3}{*}{ 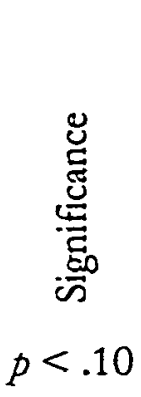 } \\
\hline & $\stackrel{g}{\mathrm{j}}$ & $\begin{array}{l}\text { ล } \\
\circ \\
\stackrel{8}{8} \\
8\end{array}$ & $\begin{array}{l}\stackrel{2}{+} \\
\stackrel{8}{8} \\
8 \\
\end{array}$ & $\begin{array}{l}\text { 亏 } \\
\stackrel{5}{8} \\
8 \\
8\end{array}$ & 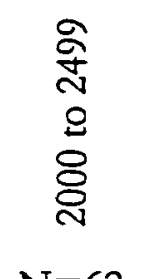 & 总 & & & \\
\hline & $N=16$ & $N=18$ & $\mathrm{~N}=31$ & $N=53$ & $N=62$ & $\mathrm{~N}=61$ & & & \\
\hline $\begin{array}{l}\text { Service as a } \\
\text { Mentor Teacher }\end{array}$ & 0 & 1 & 2 & 4 & 5 & 1 & 13 & $05.3 \%$ & .885 \\
\hline $\begin{array}{l}\text { Curriculum } \\
\text { Development } \\
\text { Meetings }\end{array}$ & 0 & 1 & 4 & 2 & 2 & 4 & 13 & $05.3 \%$ & .047 \\
\hline $\begin{array}{l}\text { Beginning } \\
\text { Teacher Support } \\
\text { \& Assessment }\end{array}$ & 1 & 0 & 0 & 2 & 2 & 0 & 6 & $02.4 \%$ & .797 \\
\hline Other & 1 & 0 & 1 & 0 & 1 & 3 & 6 & $02.4 \%$ & .035 \\
\hline $\begin{array}{l}\text { District } \\
\text { Sponsored } \\
\text { Workshops }\end{array}$ & 0 & 0 & 0 & 2 & 0 & 3 & 5 & $02.0 \%$ & .596 \\
\hline $\begin{array}{l}\text { Online/Distance } \\
\text { Learning }\end{array}$ & 1 & 1 & 0 & 1 & 0 & 1 & 4 & $01.6 \%$ & - \\
\hline $\begin{array}{l}\text { Non-Music } \\
\text { Conferences }\end{array}$ & 0 & 0 & 0 & 0 & 1 & 2 & 3 & $01.2 \%$ & $\ldots a$ \\
\hline $\begin{array}{l}\text { On-Campus } \\
\text { Inservice }\end{array}$ & 0 & 0 & 1 & 0 & 0 & 1 & 2 & $00.8 \%$ & $\ldots$ \\
\hline $\begin{array}{l}\text { Non-Music } \\
\text { Workshops }\end{array}$ & 0 & 2 & 0 & 0 & 0 & 0 & 2 & $00.8 \%$ & $\ldots a$ \\
\hline $\begin{array}{l}\text { County Office } \\
\text { of Ed. } \\
\text { Workshops }\end{array}$ & 0 & 0 & 0 & 1 & 1 & 0 & 2 & $30.8 \%$ & $\ldots a$ \\
\hline
\end{tabular}

${ }^{2}$ Sample size was $<5$

Practically significant are the data from Hosting a Guest Teacher or Clinician $(p=.141)$.

This activity, chosen by $66.9 \%$ as a most valuable activity, indicates that high school instrumental music teachers at schools with less than 1500 students chose Hosting a 
Clinician or Guest Teacher as a most valuable activity less often than did schools with other enrollments.

Table 41 presents cross tabulations between the most valuable professional growth activities identified by the respondents with the survey population's school location. The data indicate that there are three activities in which the selections of the respondents vary significantly $(p<.10)$ from the average according to the school location. These activities are (a) Educational Research, (b) District Sponsored Workshops, and (c) Curriculum Development Meetings.

The data indicate that while small percentages of the group choose these three activities as a most valuable professional growth activity, there remain significant differences within the sub-groups.

Teachers in urban schools selected Educational Research and attendance at District Sponsored Workshops more often as their most valuable professional growth activity than the rest of the survey population while teachers at rural and suburban schools choose them less than the group average.

In contrast, teachers from rural and suburban schools choose Curriculum Development Meetings more often as a most valuable professional growth activity than the survey population average while teachers at urban school choose this activity less often as a most valuable activity.

Practically significant $(p=.120)$ is the data from Being a Guest Teacher or Clinician. The data indicate that rural teachers participate in this activity less than teachers from other locations do. Considering distance and time issues associated with rural schools, this would be an appropriate conclusion. 
Table 41

Most Valuable Professional Growth Activities by School Location

\begin{tabular}{|c|c|c|c|c|c|c|}
\hline \multirow[b]{2}{*}{ Acrivity } & \multicolumn{3}{|c|}{ School Location } & \multirow[b]{2}{*}{$\begin{array}{c}\text { Total } \\
N=242\end{array}$} & \multirow{2}{*}{ 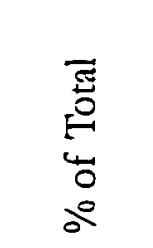 } & \multirow[b]{2}{*}{$\begin{array}{l}\text { Significance } \\
\qquad p<.10\end{array}$} \\
\hline & $\begin{array}{l}\text { Rural } \\
N=56\end{array}$ & $\begin{array}{c}\text { Suburban } \\
N=117\end{array}$ & $\begin{array}{l}\text { Urban } \\
\mathrm{N}=69\end{array}$ & & & \\
\hline Music Conferences & 46 & 85 & 50 & 181 & $74.7 \%$ & .489 \\
\hline $\begin{array}{l}\text { Observing Other } \\
\text { Rehearsals }\end{array}$ & 40 & 91 & 46 & 177 & $73.1 \%$ & .951 \\
\hline $\begin{array}{l}\text { Hosting a Guest } \\
\text { Teacher/Clinician }\end{array}$ & 32 & 83 & 47 & 162 & $66.9 \%$ & .515 \\
\hline Music Workshops & 27 & 59 & 40 & 126 & $52.0 \%$ & .274 \\
\hline Attendance at Concerts & 23 & 64 & 31 & 118 & $48.7 \%$ & .263 \\
\hline $\begin{array}{l}\text { New Music Reading } \\
\text { Session }\end{array}$ & 25 & 45 & 24 & 94 & $38.8 \%$ & .921 \\
\hline $\begin{array}{l}\text { Additional College } \\
\text { Coursework }\end{array}$ & 18 & 27 & 21 & 66 & $27.2 \%$ & .847 \\
\hline $\begin{array}{l}\text { Being a Guest } \\
\text { Teacher/Clinician }\end{array}$ & 8 & 26 & 14 & 48 & $19.8 \%$ & .120 \\
\hline $\begin{array}{l}\text { Service in a Music } \\
\text { Organization }\end{array}$ & 12 & 17 & 10 & 39 & $16.1 \%$ & .827 \\
\hline Educational Research & 3 & 9 & 10 & 22 & $09.0 \%$ & .050 \\
\hline $\begin{array}{l}\text { Peer Mentoring } \\
\text { Activities }\end{array}$ & 5 & 8 & 8 & 21 & $08.6 \%$ & .415 \\
\hline $\begin{array}{l}\text { Service as a Mentor } \\
\text { Teacher }\end{array}$ & 4 & 5 & 4 & 13 & $05.3 \%$ & .826 \\
\hline $\begin{array}{l}\text { Curriculum } \\
\text { Development Meetings }\end{array}$ & 4 & 8 & 1 & 13 & $05.3 \%$ & .026 \\
\hline $\begin{array}{l}\text { Beginning Teacher } \\
\text { Support \& Assessment }\end{array}$ & 1 & 1 & 4 & 6 & $02.4 \%$ & .844 \\
\hline Other & 1 & 5 & 0 & 6 & $02.4 \%$ & .269 \\
\hline $\begin{array}{l}\text { District Sponsored } \\
\text { Workshops }\end{array}$ & 0 & 2 & 3 & 5 & $02.0 \%$ & .007 \\
\hline
\end{tabular}




\begin{tabular}{|c|c|c|c|c|c|c|}
\hline \multirow[b]{3}{*}{ Activity } & \multicolumn{3}{|c|}{ School Location } & \multirow{3}{*}{$\begin{array}{c}\text { Total } \\
N=242\end{array}$} & \multirow{3}{*}{ 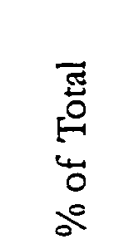 } & \multirow{3}{*}{$\begin{array}{l}\text { Significance } \\
\qquad p<.10\end{array}$} \\
\hline & & & & & & \\
\hline & $N=56$ & $\mathrm{~N}=117$ & $N=69$ & & & \\
\hline $\begin{array}{l}\text { Online/Distance } \\
\text { Learning }\end{array}$ & 3 & 1 & 0 & 4 & $01.6 \%$ & $\ldots a$ \\
\hline $\begin{array}{l}\text { Non-Music } \\
\text { Conferences }\end{array}$ & 0 & 1 & 2 & 3 & $01.2 \%$ & $-a^{a}$ \\
\hline On-Campus Inservice & 0 & 2 & 0 & 2 & $00.8 \%$ & $-\ldots$ \\
\hline Non-Music Workshops & 1 & 0 & 1 & 2 & $00.8 \%$ & $\ldots$ \\
\hline $\begin{array}{l}\text { County Office of Ed. } \\
\text { Workshops }\end{array}$ & 1 & 0 & 1 & 2 & $00.8 \%$ & $\ldots$ \\
\hline
\end{tabular}

'Sample size was $<5$

Table 42 indicates cross tabulations between the most valuable professional growth activities identified by the respondents with the survey population's music program enrollment. The data indicate that there is one activity in which the selections of the respondents vary significantly $(p<.10)$ from the average according to the music program enrollment. This activity is Educational Research.

Educational Research was chosen by $9 \%$ of the survey population as being one of the most valuable professional growth activities. Yet teachers who had fewer than 75 students and 125 to 174 students chose this activity as most valuable less often than did the rest of the group. Teachers whose programs involved 76 to 124 students and more than 225 students chose Educational Research as a valuable activity more often than the rest of the group. 
Table 42

Most Valuable Professional Growth Activities by Number of Students in the Program

\begin{tabular}{|c|c|c|c|c|c|c|c|c|}
\hline \multirow[b]{2}{*}{ Activity } & \multicolumn{5}{|c|}{ Number of Students in Program } & \multirow[b]{2}{*}{$\begin{array}{c}\text { 苛 } \\
N=242\end{array}$} & \multirow[b]{2}{*}{$\begin{array}{l}\bar{E} \\
\stackrel{5}{0} \\
0 \\
0 \\
0 \\
0\end{array}$} & \multirow[b]{2}{*}{ 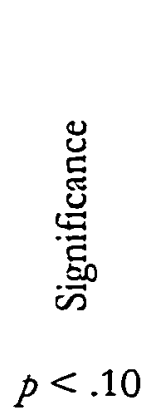 } \\
\hline & $\begin{array}{c}\stackrel{n}{V} \\
N=57\end{array}$ & 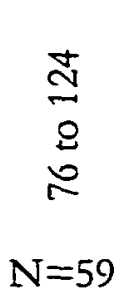 & $\begin{array}{c}\stackrel{ \pm}{ \pm} \\
\stackrel{2}{\cong} \\
N=54\end{array}$ & 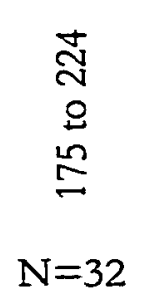 & $\begin{array}{c}\stackrel{+}{\stackrel{N}{N}} \\
N=40\end{array}$ & & & \\
\hline Music Conferences & 44 & 44 & 40 & 26 & 27 & 181 & $74.7 \%$ & .594 \\
\hline $\begin{array}{l}\text { Observing Other } \\
\text { Rehearsals }\end{array}$ & 45 & 42 & 43 & 19 & 28 & 177 & $73.1 \%$ & .578 \\
\hline $\begin{array}{l}\text { Hosting a Guest } \\
\text { Teacher/Clinician }\end{array}$ & 36 & 38 & 35 & 23 & 30 & 162 & $66.9 \%$ & .655 \\
\hline Music Workshops & 29 & 34 & 33 & 10 & 20 & 126 & $52.0 \%$ & .684 \\
\hline Attendance at Concerts & 27 & 25 & 29 & 17 & 20 & 118 & $48.7 \%$ & .626 \\
\hline $\begin{array}{l}\text { New Music Reading } \\
\text { Sessions }\end{array}$ & 24 & 16 & 19 & 15 & 20 & 94 & $38.8 \%$ & .716 \\
\hline $\begin{array}{l}\text { Additional College } \\
\text { Coursework }\end{array}$ & 15 & 17 & 15 & 11 & 8 & 66 & $27.2 \%$ & .498 \\
\hline $\begin{array}{l}\text { Being a Guest } \\
\text { Teacher/Clinician }\end{array}$ & 7 & 12 & 7 & 10 & 12 & 48 & $19.8 \%$ & .890 \\
\hline $\begin{array}{l}\text { Service in a Music } \\
\text { Organization }\end{array}$ & 6 & 12 & 5 & 7 & 9 & 39 & $16.1 \%$ & .539 \\
\hline Educational Research & 1 & 9 & 4 & 3 & 5 & 22 & $09.0 \%$ & .080 \\
\hline $\begin{array}{l}\text { Peer Mentoring } \\
\text { Activities }\end{array}$ & 6 & 9 & 2 & 1 & 3 & 21 & $08.6 \%$ & .651 \\
\hline $\begin{array}{l}\text { Service as a Mentor } \\
\text { Teacher }\end{array}$ & 2 & 2 & 4 & 1 & 4 & 13 & $05.3 \%$ & .467 \\
\hline $\begin{array}{l}\text { Curriculum } \\
\text { Development Meetings }\end{array}$ & 4 & 5 & 2 & 1 & 1 & 13 & $05.3 \%$ & .117 \\
\hline $\begin{array}{l}\text { Beginning Teacher } \\
\text { Support \& Assessment }\end{array}$ & 2 & 3 & 1 & 0 & 0 & 6 & $02.4 \%$ & .518 \\
\hline Other & 2 & 1 & 0 & 0 & 3 & 6 & $02.4 \%$ & .905 \\
\hline
\end{tabular}


Number of Students in Program

\begin{tabular}{|c|c|c|c|c|c|c|c|c|}
\hline & & & & & & & & \\
\hline Activity & $\begin{array}{c}\stackrel{\sim}{V} \\
N=57\end{array}$ & 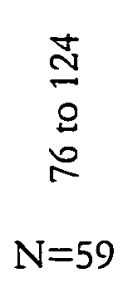 & $\begin{array}{c}\stackrel{ \pm}{ \pm} \\
\stackrel{2}{\Xi} \\
N=54\end{array}$ & 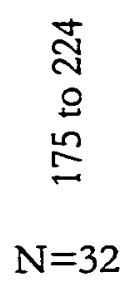 & $\begin{array}{c}\stackrel{+}{\stackrel{\mathrm{N}}{N}} \\
N=40\end{array}$ & $\begin{array}{c}\text { 吾 } \\
N=242\end{array}$ & 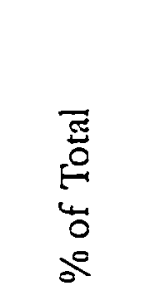 & 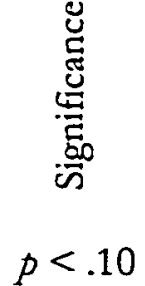 \\
\hline $\begin{array}{l}\text { District Sponsored } \\
\text { Workshops }\end{array}$ & 0 & 1 & 1 & 1 & 2 & 5 & $02.0 \%$ & .571 \\
\hline $\begin{array}{l}\text { Online/Distance } \\
\text { Learning }\end{array}$ & 2 & 1 & 1 & 0 & 0 & 4 & $01.6 \%$ & $\ldots a$ \\
\hline $\begin{array}{l}\text { Non-Music } \\
\text { Conferences }\end{array}$ & 0 & 0 & 2 & 0 & 1 & 3 & $01.2 \%$ & $\ldots a$ \\
\hline On-Campus Inservice & 0 & 1 & 0 & 1 & 0 & 2 & $00.8 \%$ & $\ldots$ \\
\hline Non-Music Workshops & 1 & 0 & 0 & 1 & 0 & 2 & $00.8 \%$ & $\ldots a$ \\
\hline $\begin{array}{l}\text { County Office of Ed. } \\
\text { Workshops }\end{array}$ & 0 & 1 & 0 & 1 & 0 & 2 & $0.8 \%$ & $\ldots a$ \\
\hline
\end{tabular}

${ }^{2}$ Sample size was $<5$

Table 43 offers cross tabulations between the most valuable professional growth activities identified by the respondents with the survey population's sex. The data indicate that there is one activity in which the selections of the respondents vary significantly $(p<.10)$ from the average according to the sex of the respondents. This activity is Peer Mentoring Activities. 
Table 43

Most Valuable Professional Growth Activities by Sex

\begin{tabular}{|c|c|c|c|c|c|c|}
\hline \multirow[b]{3}{*}{ Activity } & \multicolumn{3}{|c|}{ Sex } & \multirow[b]{2}{*}{ Total } & \multirow{3}{*}{ 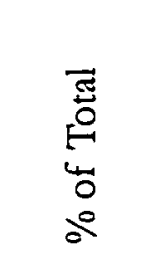 } & \multirow{3}{*}{$\begin{array}{l}\text { Significance } \\
\qquad p<.10\end{array}$} \\
\hline & Male & Female & $\begin{array}{c}\text { No } \\
\text { Response }\end{array}$ & & & \\
\hline & $N=197$ & $\mathrm{~N}=42$ & $N=3$ & $\mathrm{~N}=242$ & & \\
\hline Music Conferences & 150 & 28 & 3 & 181 & $74.7 \%$ & .894 \\
\hline $\begin{array}{l}\text { Observing Other } \\
\text { Rehearsals }\end{array}$ & 144 & 30 & 3 & 177 & $73.1 \%$ & .382 \\
\hline $\begin{array}{l}\text { Hosting a Guest } \\
\text { Teacher/Clinician }\end{array}$ & 134 & 26 & 2 & 162 & $66.9 \%$ & .787 \\
\hline Music Workshops & 103 & 22 & 1 & 126 & $52.0 \%$ & .392 \\
\hline $\begin{array}{l}\text { Attendance at } \\
\text { Concerts }\end{array}$ & 98 & 19 & 1 & 118 & $48.7 \%$ & .490 \\
\hline $\begin{array}{l}\text { New Music Reading } \\
\text { Session }\end{array}$ & 74 & 19 & 1 & 94 & $38.8 \%$ & .823 \\
\hline $\begin{array}{l}\text { Additional College } \\
\text { Coursework }\end{array}$ & 49 & 17 & 0 & 66 & $27.2 \%$ & .807 \\
\hline $\begin{array}{l}\text { Being a Guest } \\
\text { Teacher/Clinician }\end{array}$ & 42 & 4 & 2 & 48 & $19.8 \%$ & .540 \\
\hline $\begin{array}{l}\text { Service in a Music } \\
\text { Organization }\end{array}$ & 33 & 6 & 0 & 39 & $16.1 \%$ & .937 \\
\hline Educational Research & 18 & 4 & 0 & 22 & $09.0 \%$ & .366 \\
\hline $\begin{array}{l}\text { Peer Mentoring } \\
\text { Activities }\end{array}$ & 18 & 3 & 0 & 21 & $08.6 \%$ & .027 \\
\hline $\begin{array}{l}\text { Service as a Mentor } \\
\text { Teacher }\end{array}$ & 12 & 1 & 0 & 13 & $05.3 \%$ & .513 \\
\hline $\begin{array}{l}\text { Curriculum } \\
\text { Development Meetings }\end{array}$ & 11 & 2 & 0 & 13 & $05.3 \%$ & .150 \\
\hline $\begin{array}{l}\text { Beginning Teacher } \\
\text { Support \& Assessment }\end{array}$ & 4 & 1 & 1 & 6 & $02.4 \%$ & .410 \\
\hline Other & 4 & 2 & 0 & 6 & $02.4 \%$ & .276 \\
\hline
\end{tabular}




\begin{tabular}{|c|c|c|c|c|c|c|}
\hline \multirow[b]{3}{*}{ Activity } & \multicolumn{3}{|c|}{ Sex } & \multirow[b]{2}{*}{ Total } & \multirow{3}{*}{$\begin{array}{l}\text { 폰 } \\
\stackrel{0}{0} \\
0 \\
0 \\
0\end{array}$} & \multirow{3}{*}{$\begin{array}{l}\text { Significance } \\
\qquad p<.10\end{array}$} \\
\hline & Male & Female & $\begin{array}{c}\text { No } \\
\text { Response }\end{array}$ & & & \\
\hline & $N=197$ & $N=42$ & $N=3$ & $\mathrm{~N}=242$ & & \\
\hline $\begin{array}{l}\text { District Sponsored } \\
\text { Workshops }\end{array}$ & 4 & 1 & 0 & 5 & $02.0 \%$ & .510 \\
\hline $\begin{array}{l}\text { Online/Distance } \\
\text { Learning }\end{array}$ & 3 & 1 & 0 & 4 & $01.6 \%$ & $\ldots$ \\
\hline $\begin{array}{l}\text { Non-Music } \\
\text { Conferences }\end{array}$ & 2 & 1 & 0 & 3 & $01.2 \%$ & $\ldots$ \\
\hline On-Campus Inservice & 2 & 0 & 0 & 2 & $00.8 \%$ & $\ldots a$ \\
\hline Non-Music Workshops & 2 & 0 & 0 & 2 & $00.8 \%$ & $\ldots$ \\
\hline $\begin{array}{l}\text { County Office of Ed. } \\
\text { Workshops }\end{array}$ & 1 & 1 & 0 & 2 & $00.8 \%$ & $\ldots$ \\
\hline
\end{tabular}

${ }^{2}$ Sample size was $<5$

Peer Mentoring Activities was selected by $8.6 \%$ of the respondents as one of the most valuable professional growth activities, while males chose this activity as a most valuable activity more than the group average and females chose it below the group average.

Table 44 shows cross tabulations between the most valuable professional growth activities identified by the respondents with the race of the survey population.

Table 44 indicates that when the race of the survey population is cross-tabulated with the respondent's choices of most valuable activities that the resulting data did not produce significant differences.

Practically significant $(p=.106)$ is the data from Attendance at Concerts. Respondents who chose the Caucasian sub-category chose this activity as one of their most valuable activities less often than those in the two other sub-categories, Non-Caucasian and No Response. 
Table 44

Most Valuable Professional Growth Activities by Race

\begin{tabular}{|c|c|c|c|c|c|c|}
\hline \multirow[b]{3}{*}{ Activity } & \multicolumn{3}{|c|}{ Race } & \multirow[b]{2}{*}{ Total } & \multirow{3}{*}{ 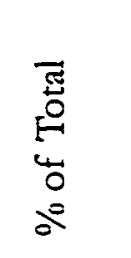 } & \multirow{3}{*}{$\begin{array}{l}\text { Significance } \\
\qquad p<.10\end{array}$} \\
\hline & Caucasian & $\begin{array}{c}\text { Non- } \\
\text { Caucasian }\end{array}$ & $\begin{array}{c}\text { No } \\
\text { Response }\end{array}$ & & & \\
\hline & $N=149$ & $N=24$ & $N=69$ & $N=242$ & & \\
\hline Music Conferences & 110 & 19 & 52 & 181 & $74.7 \%$ & .634 \\
\hline $\begin{array}{l}\text { Observing Other } \\
\text { Rehearsals }\end{array}$ & 103 & 19 & 55 & 177 & $73.1 \%$ & .495 \\
\hline $\begin{array}{l}\text { Hosting a Guest } \\
\text { Teacher/Clinician }\end{array}$ & 98 & 15 & 49 & 162 & $66.9 \%$ & .730 \\
\hline Music Workshops & 81 & 16 & 29 & 126 & $52.0 \%$ & .769 \\
\hline $\begin{array}{l}\text { Attendance at } \\
\text { Concerts }\end{array}$ & 73 & 11 & 34 & 118 & $48.7 \%$ & .106 \\
\hline $\begin{array}{l}\text { New Music Reading } \\
\text { Session }\end{array}$ & 56 & 8 & 30 & 94 & $38.8 \%$ & .639 \\
\hline $\begin{array}{l}\text { Additional College } \\
\text { Coursework }\end{array}$ & 44 & 8 & 14 & 66 & $27.2 \%$ & .549 \\
\hline $\begin{array}{l}\text { Being a Guest } \\
\text { Teacher/Clinician }\end{array}$ & 30 & 3 & 15 & 48 & $19.8 \%$ & .912 \\
\hline $\begin{array}{l}\text { Service in a Music } \\
\text { Organization }\end{array}$ & 26 & 3 & 10 & 39 & $16.1 \%$ & .916 \\
\hline Educational Research & 13 & 3 & 6 & 22 & $09.0 \%$ & .382 \\
\hline $\begin{array}{l}\text { Peer Mentoring } \\
\text { Activities }\end{array}$ & 13 & 3 & 5 & 21 & $08.6 \%$ & .751 \\
\hline $\begin{array}{l}\text { Service as a Mentor } \\
\text { Teacher }\end{array}$ & 10 & 0 & 3 & 13 & $05.3 \%$ & .563 \\
\hline $\begin{array}{l}\text { Curriculum } \\
\text { Development } \\
\text { Meetings }\end{array}$ & 6 & 2 & 5 & 13 & $05.3 \%$ & .562 \\
\hline $\begin{array}{l}\text { Beginning Teacher } \\
\text { Support \& } \\
\text { Assessment }\end{array}$ & 4 & 1 & 1 & 6 & $02.4 \%$ & .767 \\
\hline Other & 4 & 0 & 2 & 6 & $02.4 \%$ & .537 \\
\hline
\end{tabular}




\begin{tabular}{|c|c|c|c|c|c|c|}
\hline \multirow[b]{3}{*}{ Activity } & \multicolumn{3}{|c|}{ Race } & \multirow{3}{*}{$\begin{array}{c}\text { Total } \\
N=242\end{array}$} & \multirow{3}{*}{ 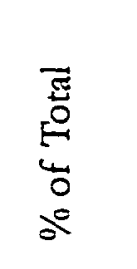 } & \multirow{3}{*}{$\begin{array}{l}\text { Significance } \\
\qquad p<.10\end{array}$} \\
\hline & Caucasian & $\begin{array}{c}\text { Non- } \\
\text { Caucasian }\end{array}$ & $\begin{array}{c}\text { No } \\
\text { Response }\end{array}$ & & & \\
\hline & $N=149$ & $\mathrm{~N}=24$ & $N=69$ & & & \\
\hline $\begin{array}{l}\text { District Sponsored } \\
\text { Workshops }\end{array}$ & 4 & 1 & 0 & 5 & $02.0 \%$ & .111 \\
\hline $\begin{array}{l}\text { Online/Distance } \\
\text { Learning }\end{array}$ & 2 & 0 & 2 & 4 & $01.6 \%$ & $\ldots$ \\
\hline $\begin{array}{l}\text { Non-Music } \\
\text { Conferences }\end{array}$ & 1 & 1 & 1 & 3 & $01.2 \%$ & $\ldots$ \\
\hline $\begin{array}{l}\text { On-Campus } \\
\text { Inservice }\end{array}$ & 1 & 0 & 1 & 2 & $00.8 \%$ & $\ldots a$ \\
\hline $\begin{array}{l}\text { Non-Music } \\
\text { Workshops }\end{array}$ & 2 & 0 & 0 & 2 & $00.8 \%$ & $\ldots a$ \\
\hline $\begin{array}{l}\text { County Office of Ed. } \\
\text { Workshops }\end{array}$ & 2 & 0 & 0 & 2 & $00.8 \%$ & $\ldots$ \\
\hline
\end{tabular}

${ }^{2}$ Sample size was $<5$

\section{Part Six: Comments Regarding Most Valuable Professional Growth Activity}

In addition to indicating their top 3-5 most valuable professional growth activities, the respondents were asked to write a brief statement indicating why they selected one activity as their most valuable. Brief statements were written by 220 survey respondents out of 242 (90.9\%) explaining why they chose their number one professional growth activity.

Fourteen of the 21 professional growth activities were chosen at least once as a most valuable activity. Table 45 identifies the activities chosen and the number of times each was mentioned. The right hand column indicates the percentage each activity earned relative to the whole group ( $N=220$ responses).

By more than 2 to 1 , the respondents wrote comments regarding Attendance at Music Conferences as their number one professional growth activity over the next activity. With 85 
comments supporting this activity, high school instrumental music teachers responded with comments such as "sharing techniques and strategies with peers, interaction with other music educators, having access to the latest merchandise and technology," and "conferences are most pertinent with flexible choices and times." Many selected conferences because it seemed to offer these teachers a sense of renewal as well as opportunities to redefine their purpose. Comments such as "inspiration to charge my batteries," and "conferences have revitalized me and sent me home with new information to assist me with my instruction" were typical. See Appendix D for a complete listing of responses given by the survey group indicating why they chose a particular activity as a number one rated activity.

Table 45

The Most Valuable Professional Growth Activity Comments From Section IV of the Survey

\begin{tabular}{lcc}
\hline Activity & Frequency & Percentage \\
\hline Attendance at Music Conferences & 85 & $38.6 \%$ \\
Having A Guest Teacher/Clinician & 38 & $17.2 \%$ \\
Observing Other Rehearsals & 26 & $11.8 \%$ \\
Attendance at Music Workshops & 23 & $10.4 \%$ \\
Taking Additional College Coursework & 12 & $05.4 \%$ \\
New Music Reading Sessions & 11 & $05.0 \%$ \\
Participating in Peer Mentoring Activities & 7 & $03.1 \%$ \\
Attendance at Concerts & 6 & $02.7 \%$ \\
Being a Guest Teacher/Clinician & 4 & $01.8 \%$ \\
Serving in Professional Music Organizations & 4 & $01.8 \%$ \\
Conducting Educational Research & 1 & $00.4 \%$
\end{tabular}




\begin{tabular}{lcc}
\hline Activity & Frequency & Percentage \\
\hline Curriculum Development Meetings & 1 & $00.4 \%$ \\
Online/Distance Learning & 1 & $00.4 \%$ \\
Other Activities (being a musician in an orch.) & 1 & $00.4 \%$ \\
Total & 220 & $100.0 \%$ \\
\hline
\end{tabular}

Hosting a Guest Teacher/Clinician and Observing Other Rehearsals were selected by $17.2 \%$ and $11.8 \%$ of the survey group respectively. Typical comments in support of these activities included those such as "having a clinician work with my group enables me to receive feedback on areas I may overlook. It also gives the students and myself the chance to get another interpretation of the music we are preparing." "Observing Other Rehearsals helps me learn how effective different teaching techniques are." Finally, "observing educators' work in their classrooms is very enlightening for me. I can watch conducting styles, discipline techniques, and overall rehearsal tips. From there I can analyze my own teaching and directing and see what I can use with my own groups."

Attendance at Music Workshops ranked fourth in frequency, and 10.4\% of the group selected this activity as their most valuable. One teacher stated that "Music Workshops are more activity based and I get practical experience. Also, I am surrounded by other musicians eager to learn and improve and have the opportunity to talk with them, share ideas, and renew enthusiasm."

A number of activities were chosen as the most valuable by fewer than $6 \%$ of the respondents. These activities included (a) taking Additional College Coursework at $5.4 \%$, (b) New Music Reading Sessions at 5.0\%, (c) participating in Peer Mentoring Activities at 3.1\%, 
(d) Attendance at Concerts at $2.7 \%$, (e) Being a Guest Teacher/Clinician and (f) Serving in a Professional Music Organization at $1.8 \%$.

Typical teacher comments regarding Additional College Coursework were "coursework directly related to my passion and applicable to teaching activity as well." Comments about New Music Reading Sessions included those such as the following: "The choice of literature is (an) important decision because it motivates kids, determines teaching lessons, concerts and performance and festival effectiveness."

Peer Mentoring Activities elicited comments from one teacher who wrote, "When I began as a teacher I was fortunate to have regular observations by the district supervisor of fine arts. He provided me immediate feedback as to what went well and how to fix that which did not. He was also able to 'clinic' the group - mostly to demonstrate rehearsal techniques for me. I believe this allowed me the fastest growth as a teacher. I had a private teacher, if you will."

Attendance at Concerts generated comments such as, "Observing professionals perform and listening to music give me inspiration to make a high school ensemble (sound) like the pros."

Being a Guest Teacher/Clinician "challenges your ability to teach - like being in front of an unknown groups for a short period of time," wrote one teacher. "You have precious little time to transmit both your knowledge and love of music, so you really have to have a good handle on your skills."

When commenting about serving in a professional music organization one teacher wrote, "I have gained a tremendous amount of advice and information from my colleagues who share similar situations. It may not be directly presented, but I absorb attitudes, 
perspectives, and ideas from the experiences we share. District and county-level workshops do not usually even have a concept of what we do."

Conducting Educational Research, Curriculum Development Meetings, Online/Distance Learning, and Being a Musician in an Orchestra were each selected by one respondent as being their most valuable professional growth activity.

Seven professional growth activities did not receive any selections and comments as a most valuable professional growth activity. These were (a) On-Campus Inservice, (b) Service as a Mentor Teacher, (c) Non-Music Workshops, (d) District Sponsored Workshops, (e) Non-Music Conferences, (f) County Office of Education Workshops, and (g) Beginning Teacher Support and Assessment activities (see Table 45).

\section{Part Seven: Cross Tabulations between the Least Valuable Professional Growth Activities and \\ Demographics}

The final area of analysis was to identify the respondent's 3-5 least valuable professional growth activities. Eleven demographic categories were chosen for cross-tabulation with the responses from section IV of the survey instrument (Appendix B). After numbers from section IV where totaled, the sums were cross tabulated with the ordinal data from the demographic section and a Spearman Correlation $(p<.10)$ test was run to discover any significant difference between the two sets of data.

Demographic data utilized in the cross tabulations included: (a) number of years teaching, (b) number of years in the current job, (c) level of education, (d) type of California teaching credential, (e) the amount of district reimbursement for professional growth expenses, $(f)$ the number of high school instrumental teachers in the district, $(g)$ the size of school, (h) the school location, (i) the number of students in the instrumental music 
program at each site, $(j)$ sex, and $(k)$ race of the respondents. Tables 46 through 56 present the cross-tabulation data for these eleven demographic categories.

These cross tabulations were analyzed in order to determine differences between selection levels of respondents least valuable professional growth activities and the demographic categories to establish any significant differences among the preferences of any of the sub-groups.

If the data in any of the sub-groups differ significantly as a result of the Spearman tho test (which shows the probability that there is a variation among one or more of the subgroups within the professional growth activity) then further analysis was performed. Additional analysis determined the extent to which the expected number of responses fell above or below the actual number.

For example, if an activity has less than .10 in the probability column following the Spearman tho cross tabulations, then a significant difference exists in one of the sub-groups within that activity. Taking the total number of responses from each sub-group and multiplying that number by the total percentage in the activity row results in datum that represents the expected number of responses within each sub-group. These findings will be expressed in percentages in the analysis of the data in each table.

Each table is organized by listing the activities in descending order based upon the total percentage of responses supplied by the survey population. The total population average level of each activity is indicated in the column with the heading "\% of Total."

In all of the following cross-tabulation tables, the terms "Activity," "Category," "SubCategory," "Sub-Groups," and "Groupings" are used in accordance with the explanations and definitions presented in Chapter Three of this study. 
The data in Tables 46 through 56 also indicate the total number of selections made by the survey population in each activity. This amount is found in the column labeled "Total $\mathrm{N}=242$ " and further reinforces the mean score rankings made by the survey population in Table 22.

Five activities (see Tables 46 through 56 ) were chosen by $46 \%$ or more of the survey population as one of their least valuable professional growth activities. These activities were Non-Music Workshops which was selected by $57.7 \%$ of the group and On-Campus Inservice, which was chosen by $50.8 \%$. Non-Music Conferences were identified by $49.1 \%$ and District Sponsored Workshops were chosen by $48.3 \%$ of the group. Completing the list of least valuable activities was County Office of Education Workshops, which was chosen by $46.6 \%$ of the population.

The data displayed in Tables 46 through 56 in the "\% of Total" column is almost an exact reverse of the data displayed in Tables 34 though 44 in the "\% of Total" column, which indicated the most valuable activities as selected by the survey population. The difference is that in Tables 46 through 56, the total percentage of the population responding to each activity is less overall than the percentage of responses in Tables 34 through 44 . For example, the top two activities in Table 34 had response rates of $74.7 \%$ and $73.1 \%$ respectively while the top two rates of responses in Table 46 were $57.4 \%$ and $50.8 \%$ respectively. There are two observations worth noting. First, this seems to indicate that respondents were more inclined to chose more of the activities that they felt were valuable rather than take a critical approach by identifying many activities they felt were not valuable. Second, the data presented in Tables 46 through 56 reinforce the data presented in the other parts of this chapter because approaches that attempt to explore the problems of this study from opposite sides contribute to data validity. 
Table 46 indicates cross tabulations between the least valuable professional growth activities identified by the respondents with the survey population's number of years as a teacher. The data indicate that there is one activity in which the selections of the respondents vary significantly $(p<.10)$ from the average according to the number of years as a teacher. This activity is Beginning Teacher Support and Assessment.

Table 46

Least Valuable Professional Growth Activities by Number of Years Teaching

\begin{tabular}{|c|c|c|c|c|c|c|c|c|}
\hline \multirow[b]{3}{*}{ Activity } & \multicolumn{5}{|c|}{ Number of Years Teaching } & \multirow{3}{*}{$\begin{array}{c}\text { Total } \\
N=242\end{array}$} & \multirow{3}{*}{ 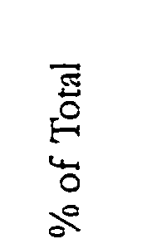 } & \multirow{3}{*}{$\begin{array}{l}\text { Sig. } \\
p<.10\end{array}$} \\
\hline & $0-2$ & $3-5$ & $6-10$ & $11-14$ & $15+$ & & & \\
\hline & $N=38$ & $N=31$ & $N=46$ & $N=32$ & $N=95$ & & & \\
\hline $\begin{array}{l}\text { Non-Music } \\
\text { Workshops }\end{array}$ & 20 & 20 & 27 & 19 & 53 & 139 & $57.4 \%$ & .513 \\
\hline On-Campus Inservice & 19 & 17 & 24 & 19 & 44 & 123 & $50.8 \%$ & .251 \\
\hline $\begin{array}{l}\text { Non-Music } \\
\text { Conferences }\end{array}$ & 20 & 15 & 22 & 14 & 48 & 119 & $49.1 \%$ & .107 \\
\hline $\begin{array}{l}\text { District Sponsored } \\
\text { Workshops }\end{array}$ & 18 & 13 & 21 & 11 & 54 & 117 & $48.3 \%$ & .226 \\
\hline $\begin{array}{l}\text { County Office of Ed. } \\
\text { Workshops }\end{array}$ & 9 & 13 & 25 & 19 & 47 & 113 & $46.6 \%$ & .407 \\
\hline $\begin{array}{l}\text { Curriculum } \\
\text { Development } \\
\text { Meetings }\end{array}$ & 11 & 8 & 9 & 12 & 31 & 71 & $29.3 \%$ & .919 \\
\hline $\begin{array}{l}\text { Online/Distance } \\
\text { Learning }\end{array}$ & 8 & 11 & 11 & 8 & 22 & 60 & $24.7 \%$ & .424 \\
\hline $\begin{array}{l}\text { Beginning Teacher } \\
\text { Support \& Assessment }\end{array}$ & 10 & 5 & 12 & 3 & 16 & 46 & $19.0 \%$ & .098 \\
\hline Educational Research & 5 & 7 & 6 & 7 & 20 & 45 & $18.5 \%$ & .613 \\
\hline $\begin{array}{l}\text { Service in a Music } \\
\text { Organization }\end{array}$ & 3 & 3 & 9 & 3 & 8 & 26 & $10.7 \%$ & .456 \\
\hline
\end{tabular}




\begin{tabular}{|c|c|c|c|c|c|c|c|c|}
\hline \multirow[b]{2}{*}{ Activity } & \multicolumn{5}{|c|}{ Number of Years Teaching } & \multirow[b]{2}{*}{$\begin{array}{c}\text { Total } \\
N=242\end{array}$} & \multirow{2}{*}{$\begin{array}{l}\text { 焉 } \\
\text { 宸 } \\
0\end{array}$} & \multirow[b]{2}{*}{$\begin{array}{c}\text { Sig. } \\
p<.10\end{array}$} \\
\hline & $\begin{array}{c}0-2 \\
N=38\end{array}$ & $\begin{array}{c}3-5 \\
N=31\end{array}$ & $\begin{array}{c}6-10 \\
N=46\end{array}$ & $\begin{array}{l}11-14 \\
N=32\end{array}$ & $\begin{array}{c}15+ \\
N=95\end{array}$ & & & \\
\hline $\begin{array}{l}\text { Additional College } \\
\text { Coursework }\end{array}$ & 4 & 0 & 4 & 2 & 8 & 18 & $07.4 \%$ & .395 \\
\hline $\begin{array}{l}\text { Service as a Mentor } \\
\text { Teacher }\end{array}$ & 2 & 1 & 3 & 2 & 6 & 14 & $05.7 \%$ & .208 \\
\hline $\begin{array}{l}\text { Peer Mentoring } \\
\text { Activities }\end{array}$ & 2 & 1 & 3 & 2 & 4 & 12 & $04.9 \%$ & .455 \\
\hline $\begin{array}{l}\text { Being a Guest } \\
\text { Teacher/Clinician }\end{array}$ & 1 & 1 & 1 & 1 & 3 & 7 & $02.8 \%$ & .374 \\
\hline $\begin{array}{l}\text { New Music Reading } \\
\text { Sessions }\end{array}$ & 1 & 2 & 1 & 1 & 1 & 6 & $02.4 \%$ & 1.000 \\
\hline Music Workshops & 0 & 0 & 0 & 0 & 4 & 4 & $01.6 \%$ & $--^{a}$ \\
\hline $\begin{array}{l}\text { Attendance at } \\
\text { Concerts }\end{array}$ & 1 & 0 & 0 & 0 & 3 & 4 & $01.6 \%$ & $--^{a}$ \\
\hline Music Conferences & 0 & 0 & 1 & 1 & 1 & 3 & $01.2 \%$ & $\ldots$ \\
\hline $\begin{array}{l}\text { Hosting a Guest } \\
\text { Teacher/Clinician }\end{array}$ & 1 & 0 & 1 & 0 & 0 & 2 & $00.8 \%$ & $\ldots$ \\
\hline $\begin{array}{l}\text { Observing Other } \\
\text { Rehearsals }\end{array}$ & 0 & 0 & 0 & 1 & 0 & 1 & $00.4 \%$ & $\ldots$ \\
\hline
\end{tabular}

${ }^{2}$ Sample size was $<5$

Beginning Teachers Support and Assessment was chosen by $19 \%$ of the survey population as one of the least valuable professional growth activities. Teachers with $0-2$ and 6-10 years of teaching experience chose this activity more often as their least valuable activity. Teachers with 3-5 and more than 10 years of experience chose Beginning Teacher Support and Assessment less often as their least valuable experience.

Table 47 presents cross tabulations between the least valuable professional growth activities identified by the respondents with the survey population's number of years in their 
current job. The data indicate two activities in which the selections of the respondents vary significantly $(p<.10)$ from the average according to the number of years in their current job. These activities are Curriculum Development Meetings and Service in a Music Organization.

Curriculum Development Meetings were chosen by $29.3 \%$ of the survey respondents as one of their least valuable professional growth activities. Teachers with between $6-10$ years in their current job chose this activity less than the average of the group and teachers with more than 10 years chose this activity more than the group average.

Service in a Music Organization was chosen by $10.7 \%$ of the group. Teachers who had been in their jobs between $6-10$ years chose this activity more as a least valuable activity and teachers who have been in their current job between 3-5 and more than 15 years chose this activity less than the group average.

Table 47

Least Valuable Professional Growth Activities by Years in Current Job

\begin{tabular}{|c|c|c|c|c|c|c|c|c|}
\hline \multirow{3}{*}{ Activity } & \multicolumn{5}{|c|}{ Number of Years in Current Job } & \multirow{3}{*}{$\begin{array}{c}\text { Total } \\
N=242\end{array}$} & \multirow{3}{*}{ 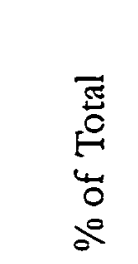 } & \multirow{3}{*}{$\begin{array}{c}\text { Sig. } \\
p<.10\end{array}$} \\
\hline & $0-2$ & $3-5$ & $6-10$ & $11-14$ & $15+$ & & & \\
\hline & $N=63$ & $\mathrm{~N}=54$ & $\mathrm{~N}=61$ & $\mathrm{~N}=25$ & $N=39$ & & & \\
\hline $\begin{array}{l}\text { Non-Music } \\
\text { Workshops }\end{array}$ & 35 & 33 & 36 & 15 & 20 & 139 & $57.4 \%$ & .273 \\
\hline On-Campus Inservice & 33 & 31 & 31 & 12 & 16 & 123 & $50.8 \%$ & .600 \\
\hline $\begin{array}{l}\text { Non-Music } \\
\text { Conferences }\end{array}$ & 33 & 28 & 26 & 13 & 19 & 119 & $49.1 \%$ & .969 \\
\hline $\begin{array}{l}\text { District Sponsored } \\
\text { Workshops }\end{array}$ & 27 & 25 & 31 & 13 & 21 & 117 & $48.3 \%$ & .537 \\
\hline $\begin{array}{l}\text { County Office of Ed. } \\
\text { Workshops }\end{array}$ & 19 & 24 & 36 & 16 & 18 & 113 & $46.6 \%$ & .565 \\
\hline
\end{tabular}




\begin{tabular}{|c|c|c|c|c|c|c|c|c|}
\hline \multirow{3}{*}{ Activity } & \multicolumn{5}{|c|}{ Number of Years in Current Job } & \multirow{3}{*}{$\begin{array}{c}\text { Total } \\
N=242\end{array}$} & \multirow{3}{*}{$\begin{array}{l}\text { 푬 } \\
\text { 量 } \\
0 \\
0 \\
0\end{array}$} & \multirow{3}{*}{$\begin{array}{c}\text { Sig. } \\
p<.10\end{array}$} \\
\hline & $0-2$ & $3-5$ & $6-10$ & $11-14$ & $15+$ & & & \\
\hline & $N=63$ & $N=54$ & $N=61$ & $\mathrm{~N}=25$ & $\mathrm{~N}=39$ & & & \\
\hline $\begin{array}{l}\text { Curriculum } \\
\text { Development } \\
\text { Meetings }\end{array}$ & 18 & 16 & 13 & 8 & 16 & 71 & $29.3 \%$ & .085 \\
\hline $\begin{array}{l}\text { Online/Distance } \\
\text { Learning }\end{array}$ & 20 & 14 & 12 & 5 & 9 & 60 & $24.7 \%$ & .765 \\
\hline $\begin{array}{l}\text { Beginning Teacher } \\
\text { Support \& } \\
\text { Assessment }\end{array}$ & 16 & 11 & 10 & 3 & 6 & 46 & $19.0 \%$ & .409 \\
\hline Educational Research & 10 & 9 & 9 & 6 & 11 & 45 & $18.5 \%$ & .655 \\
\hline $\begin{array}{l}\text { Service in a Music } \\
\text { Organization }\end{array}$ & 8 & 5 & 8 & 3 & 2 & 26 & $10.7 \%$ & .056 \\
\hline $\begin{array}{l}\text { Additional College } \\
\text { Coursework }\end{array}$ & 4 & 5 & 2 & 2 & 5 & 18 & $07.4 \%$ & .502 \\
\hline $\begin{array}{l}\text { Service as a Mentor } \\
\text { Teacher }\end{array}$ & 4 & 1 & 6 & 0 & 3 & 14 & $05.7 \%$ & .119 \\
\hline $\begin{array}{l}\text { Peer Mentoring } \\
\text { Activities }\end{array}$ & 5 & 3 & 2 & 0 & 2 & 12 & $04.9 \%$ & .775 \\
\hline $\begin{array}{l}\text { Being a Guest } \\
\text { Teacher/Clinician }\end{array}$ & 2 & 0 & 2 & 0 & 3 & 7 & $02.8 \%$ & .862 \\
\hline $\begin{array}{l}\text { New Music Reading } \\
\text { Sessions }\end{array}$ & 2 & 2 & 1 & 0 & 1 & 6 & $02.4 \%$ & .905 \\
\hline Music Workshops & 0 & 1 & 0 & 0 & 3 & 4 & $01.6 \%$ & $-\ldots$ \\
\hline $\begin{array}{l}\text { Attendance at } \\
\text { Concerts }\end{array}$ & 1 & 0 & 1 & 0 & 2 & 4 & $01.6 \%$ & $\ldots$ \\
\hline Music Conferences & 2 & 0 & 0 & 0 & 1 & 3 & $01.2 \%$ & $--^{a}$ \\
\hline $\begin{array}{l}\text { Hosting a Guest } \\
\text { Teacher/Clinician }\end{array}$ & 1 & 0 & 1 & 0 & 0 & 2 & $00.8 \%$ & $\ldots$ \\
\hline $\begin{array}{l}\text { Observing Other } \\
\text { Rehearsals }\end{array}$ & 1 & 0 & 0 & 0 & 0 & 1 & $00.4 \%$ & $--^{a}$ \\
\hline
\end{tabular}

${ }^{2}$ Sample size was $<5$ 
Table 48 displays cross tabulations between the least valuable professional growth activities identified by the respondents with the survey population's level of education.

Table 48 indicates that none of the cross tabulations between the activities and the level of education resulted in a significant difference $(p<10)$ between the variables. This statistic reveals that all levels of education constantly chose these activities as a least valuable activity.

Table 48

Least Valuable Professional Growth Activities by Level of Education

\begin{tabular}{|c|c|c|c|c|c|c|c|c|c|}
\hline \multirow[b]{2}{*}{ Activity } & \multicolumn{6}{|c|}{ Level of Education } & \multirow[b]{2}{*}{$\begin{array}{c}\stackrel{\Xi}{\mathbb{C}} \\
N=242\end{array}$} & \multirow[b]{2}{*}{ 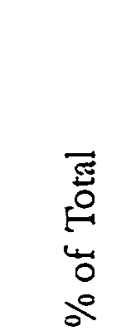 } & \multirow[b]{2}{*}{$\begin{array}{l}\text { Sig. } \\
p<.10\end{array}$} \\
\hline & $\begin{array}{l}\stackrel{\Xi}{\Xi} \frac{\underline{n}}{m} \\
N=129\end{array}$ & 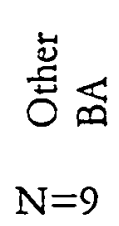 & 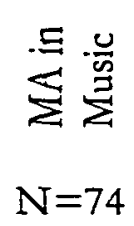 & 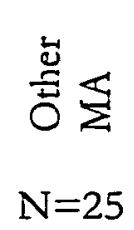 & 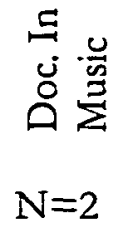 & $\begin{array}{l}\stackrel{\grave{\Xi}}{5} \stackrel{0}{0} \\
N=3\end{array}$ & & & \\
\hline $\begin{array}{l}\text { Non-Music } \\
\text { Workshops }\end{array}$ & 76 & 5 & 38 & 17 & 2 & 1 & 139 & $57.4 \%$ & .715 \\
\hline $\begin{array}{l}\text { On-Campus } \\
\text { Inservice }\end{array}$ & 68 & 6 & 40 & 9 & 0 & 0 & 123 & $50.8 \%$ & .771 \\
\hline $\begin{array}{l}\text { Non-Music } \\
\text { Conferences }\end{array}$ & 65 & 7 & 33 & 13 & 1 & 0 & 119 & $49.1 \%$ & .288 \\
\hline $\begin{array}{l}\text { District } \\
\text { Sponsored } \\
\text { Workshops }\end{array}$ & 68 & 3 & 33 & 10 & 0 & 3 & 117 & $48.3 \%$ & .736 \\
\hline $\begin{array}{l}\text { County Office of } \\
\text { Ed. Workshops }\end{array}$ & 60 & 3 & 37 & 9 & 1 & 3 & 113 & $46.6 \%$ & .941 \\
\hline $\begin{array}{l}\text { Curriculum } \\
\text { Development } \\
\text { Meetings }\end{array}$ & 35 & 5 & 20 & 8 & 1 & 2 & 71 & $29.3 \%$ & .112 \\
\hline $\begin{array}{l}\text { Online/Distance } \\
\text { Learning }\end{array}$ & 31 & 4 & 19 & 5 & 0 & 1 & 60 & $24.7 \%$ & .324 \\
\hline $\begin{array}{l}\text { Beginning } \\
\text { Teacher Support } \\
\text { \& Assessment }\end{array}$ & 20 & 1 & 18 & 5 & 1 & 1 & 46 & $19.0 \%$ & .460 \\
\hline
\end{tabular}




\begin{tabular}{|c|c|c|c|c|c|c|c|c|c|}
\hline \multirow[b]{2}{*}{ Activity } & \multicolumn{6}{|c|}{ Level of Education } & \multirow[b]{2}{*}{$\begin{array}{c}\text { Еूँ } \\
N=242\end{array}$} & \multirow[b]{2}{*}{ 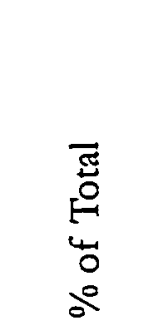 } & \multirow[b]{2}{*}{$\begin{array}{l}\text { Sig. } \\
p<.10\end{array}$} \\
\hline & 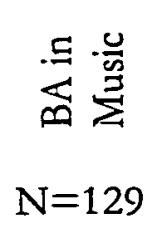 & $\begin{array}{l}\stackrel{\stackrel{\Xi}{ \pm}}{\Delta} \nwarrow \\
N=9\end{array}$ & 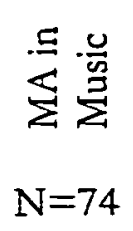 & $\begin{array}{l}\stackrel{\vec{\Xi}}{0} \leqq \\
N=25\end{array}$ & 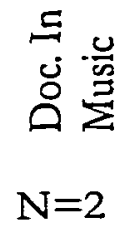 & 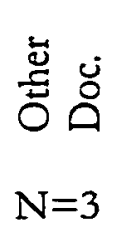 & & & \\
\hline $\begin{array}{l}\text { Educational } \\
\text { Research }\end{array}$ & 24 & 3 & 12 & 5 & 1 & 0 & 45 & $18.5 \%$ & .109 \\
\hline $\begin{array}{l}\text { Service in a } \\
\text { Music } \\
\text { Organization }\end{array}$ & 13 & 1 & 9 & 3 & 0 & 0 & 26 & $10.7 \%$ & .673 \\
\hline $\begin{array}{l}\text { Additional } \\
\text { College } \\
\text { Coursework }\end{array}$ & 6 & 1 & 6 & 3 & 1 & 1 & 18 & $07.4 \%$ & .177 \\
\hline $\begin{array}{l}\text { Service as a } \\
\text { Mentor Teacher }\end{array}$ & 7 & 0 & 6 & 1 & 0 & 0 & 14 & $05.7 \%$ & .125 \\
\hline $\begin{array}{l}\text { Peer Mentoring } \\
\text { Activities }\end{array}$ & 6 & 0 & 4 & 1 & 0 & 1 & 12 & $04.9 \%$ & .239 \\
\hline $\begin{array}{l}\text { Being a Guest } \\
\text { Teacher/Clinician }\end{array}$ & 5 & 0 & 1 & 1 & 0 & 0 & 7 & $02.8 \%$ & .837 \\
\hline $\begin{array}{l}\text { New Music } \\
\text { Reading Sessions }\end{array}$ & 3 & 1 & 2 & 0 & 0 & 0 & 6 & $02.4 \%$ & .192 \\
\hline Music Workshops & 1 & 0 & 3 & 0 & 0 & 0 & 4 & $01.6 \%$ & $\ldots$ \\
\hline $\begin{array}{l}\text { Attendance at } \\
\text { Concerts }\end{array}$ & 0 & 2 & 1 & 1 & 0 & 0 & 4 & $01.6 \%$ & $\ldots$ \\
\hline $\begin{array}{l}\text { Music } \\
\text { Conferences }\end{array}$ & 2 & 0 & 1 & 0 & 0 & 0 & 3 & $01.2 \%$ & $\ldots$ \\
\hline $\begin{array}{l}\text { Hosting a Guest } \\
\text { Teacher/Clinician }\end{array}$ & 2 & 0 & 0 & 0 & 0 & 0 & 2 & $00.8 \%$ & $\ldots$ \\
\hline $\begin{array}{l}\text { Observing Other } \\
\text { Rehearsals }\end{array}$ & 1 & 0 & 0 & 0 & 0 & 0 & 1 & $00.4 \%$ & -..a \\
\hline
\end{tabular}

${ }^{2}$ Sample size was $<5$

Practically significant (see Table 48) are the data from Curriculum Development Meetings $(p=.112)$ and Educational Research activities $(p=.109)$. Teachers with bachelors in 
music or masters in music chose Curriculum Development most often as one of their least valuable activities. Teachers with masters in music chose Educational Research more often as one of their least valuable professional growth activities.

Table 49

Least Valuable Professional Growth Activities by California Teaching Credential

\begin{tabular}{|c|c|c|c|c|c|c|c|c|c|}
\hline \multirow[b]{2}{*}{ Activity } & \multicolumn{6}{|c|}{ California Teaching Credential } & \multirow[b]{2}{*}{$\begin{array}{c}\text { 吾 } \\
\mathrm{N}=242\end{array}$} & \multirow[b]{2}{*}{ 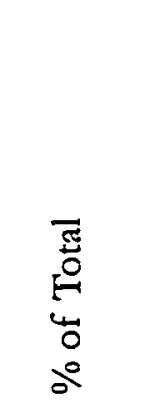 } & \multirow[b]{2}{*}{$\begin{array}{l}\text { Sig. } \\
p<.10\end{array}$} \\
\hline & 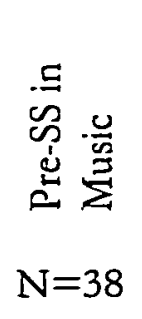 & 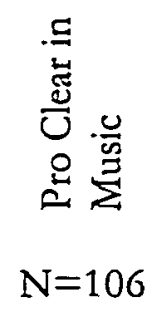 & $\begin{array}{l}\stackrel{\Xi}{\leftrightarrows} \\
\stackrel{心}{\leftrightarrows} \\
N=73\end{array}$ & 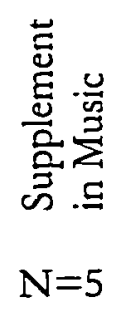 & $\begin{array}{l}\stackrel{\Xi}{\leftrightarrows} \\
N=2\end{array}$ & 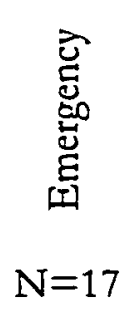 & & & \\
\hline $\begin{array}{l}\text { Non-Music } \\
\text { Workshops }\end{array}$ & 22 & 71 & 32 & 4 & 1 & 9 & 139 & $57.4 \%$ & .310 \\
\hline $\begin{array}{l}\text { On-Campus } \\
\text { Inservice }\end{array}$ & 21 & 57 & 36 & 2 & 0 & 7 & 123 & $50.8 \%$ & .884 \\
\hline $\begin{array}{l}\text { Non-Music } \\
\text { Conferences }\end{array}$ & 16 & 52 & 38 & 3 & 1 & 9 & 119 & $49.1 \%$ & .942 \\
\hline $\begin{array}{l}\text { District } \\
\text { Sponsored } \\
\text { Workshops }\end{array}$ & 23 & 47 & 37 & 2 & 1 & 7 & 117 & $48.3 \%$ & .760 \\
\hline $\begin{array}{l}\text { County Office of } \\
\text { Ed. Workshops }\end{array}$ & 18 & 55 & 34 & 2 & 0 & 4 & 113 & $46.6 \%$ & .446 \\
\hline $\begin{array}{l}\text { Curriculum } \\
\text { Development } \\
\text { Meetings }\end{array}$ & 9 & 29 & 22 & 4 & 1 & 6 & 71 & $29.3 \%$ & .082 \\
\hline $\begin{array}{l}\text { Online/ } \\
\text { Distance } \\
\text { Learning }\end{array}$ & 11 & 29 & 14 & 0 & 1 & 5 & 60 & $24.7 \%$ & .373 \\
\hline $\begin{array}{l}\text { Beginning } \\
\text { Teacher Support } \\
\text { \& Assessment }\end{array}$ & 9 & 18 & 15 & 0 & 0 & 4 & 46 & $19.0 \%$ & .893 \\
\hline $\begin{array}{l}\text { Educational } \\
\text { Research }\end{array}$ & 7 & 17 & 17 & 0 & 0 & 4 & 45 & $18.5 \%$ & .585 \\
\hline
\end{tabular}




\begin{tabular}{|c|c|c|c|c|c|c|c|c|c|}
\hline \multirow[b]{2}{*}{ Activity } & \multicolumn{6}{|c|}{ California Teaching Credential } & \multirow[b]{2}{*}{$\begin{array}{c}\text { 吾 } \\
N=242\end{array}$} & \multirow[b]{2}{*}{$\begin{array}{l}\text { 류 } \\
0 \\
0 \\
0 \\
0 \\
0\end{array}$} & \multirow[b]{2}{*}{$\begin{array}{l}\text { Sig. } \\
p<.10\end{array}$} \\
\hline & 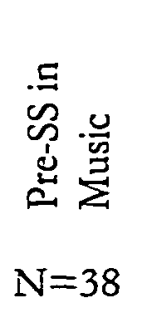 & 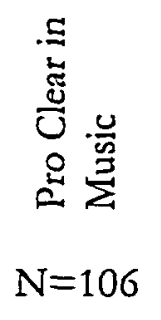 & 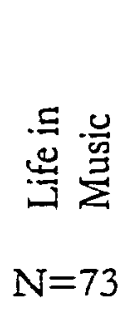 & 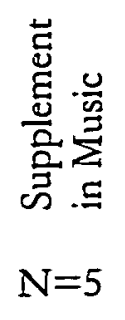 & $\begin{array}{l}\stackrel{\Xi}{\stackrel{\Xi}{U}} \\
N=2\end{array}$ & 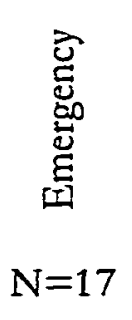 & & & \\
\hline $\begin{array}{l}\text { Service in a } \\
\text { Music } \\
\text { Organization }\end{array}$ & 1 & 15 & 6 & 1 & 0 & 3 & 26 & $10.7 \%$ & .351 \\
\hline $\begin{array}{l}\text { Additional } \\
\text { College } \\
\text { Coursework }\end{array}$ & 1 & 4 & 9 & 0 & 0 & 4 & 18 & $07.4 \%$ & .832 \\
\hline $\begin{array}{l}\text { Service as a } \\
\text { Mentor Teacher }\end{array}$ & 1 & 6 & 6 & 0 & 0 & 1 & 14 & $05.7 \%$ & .474 \\
\hline $\begin{array}{l}\text { Peer Mentoring } \\
\text { Activities }\end{array}$ & 2 & 3 & 5 & 0 & 0 & 2 & 12 & $04.9 \%$ & .753 \\
\hline $\begin{array}{l}\text { Being a Guest } \\
\text { Teacher/Clinician }\end{array}$ & 2 & 1 & 4 & 0 & 0 & 0 & 7 & $02.8 \%$ & .543 \\
\hline $\begin{array}{l}\text { New Music } \\
\text { Reading Sessions }\end{array}$ & 1 & 4 & 0 & 0 & 0 & 1 & 6 & $02.4 \%$ & .477 \\
\hline Music Workshops & 0 & 1 & 3 & 0 & 0 & 0 & 4 & $01.6 \%$ & $-a^{a}$ \\
\hline $\begin{array}{l}\text { Attendance at } \\
\text { Concerts }\end{array}$ & 0 & 0 & 3 & 1 & 0 & 0 & 4 & $01.6 \%$ & $-\ldots$ \\
\hline $\begin{array}{l}\text { Music } \\
\text { Conferences }\end{array}$ & 0 & 2 & 1 & 0 & 0 & 0 & 3 & $01.2 \%$ & $\ldots$ \\
\hline $\begin{array}{l}\text { Hosting a Guest } \\
\text { Teacher/Clinician }\end{array}$ & 1 & 1 & 0 & 0 & 0 & 0 & 2 & $00.8 \%$ & $\ldots$ \\
\hline $\begin{array}{l}\text { Observing Other } \\
\text { Rehearsals }\end{array}$ & 0 & 1 & 0 & 0 & 0 & 0 & 1 & $00.4 \%$ & $\ldots$ \\
\hline
\end{tabular}

${ }^{2}$ Sample size was $<5$

Table 49 displays cross tabulations between the least valuable professional growth activities identified by the respondents with the survey population's type of California teaching credential. The data indicate that there is one activity in which the selections of the 
respondents vary significantly $(p<.10)$ from the average according to the type of teaching credential. This activity is Curriculum Development Meetings.

Teachers with life credentials, supplemental credentials, and emergency credentials chose Curriculum Development Meetings as a least valuable professional growth activity less than the $29.3 \%$ rate of the entire group. Teachers with preliminary credentials and professional clear credentials chose Curriculum Development Meetings as a least valuable activity more than the $29.3 \%$ rate of the entire group.

Table 50 shows cross tabulations between the least valuable professional growth activities identified by the respondents with the survey population's amount of district reimbursement for professional growth expenses. The data indicate that there is one activity in which the selections of the respondents vary significantly $(p<.10)$ from the average according to the amount of reimbursement. This activity is Non-Music Workshops.

Non-Music Workshops were chosen by $57.4 \%$ of the respondents as one of the least valuable professional growth activities. Teachers who did not respond, received no district reimbursement, or were reimbursed for all of their expenses selected Non-Music Workshops less often as a least valuable activity. Teachers who received between $\$ 500$ to $\$ 999$ chose this activity more as a least valuable activity than the average of the group. 
Table 50

Least Valuable Professional Growth Activities by Amount of District Reimbursement

\begin{tabular}{|c|c|c|c|c|c|c|c|c|c|}
\hline \multirow[b]{2}{*}{ Activity } & \multicolumn{6}{|c|}{ Amount of District Reimbursement } & \multirow[b]{2}{*}{$\begin{array}{c}\text { हैं } \\
N=242\end{array}$} & \multirow[b]{2}{*}{ 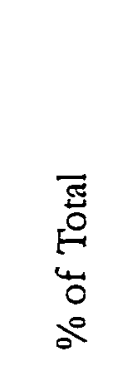 } & \multirow[b]{2}{*}{$\begin{array}{l}\text { Sig. } \\
p<.10\end{array}$} \\
\hline & 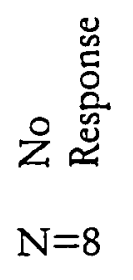 & $\begin{array}{c}\stackrel{\mathscr{Z}}{\mathrm{Z}} \\
\mathrm{N}=78\end{array}$ & $\begin{array}{c}\underset{\mathcal{N}}{\stackrel{8}{V}} \\
N=62\end{array}$ & 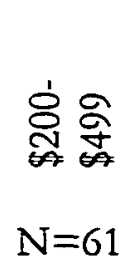 & 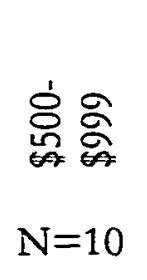 & $\stackrel{\infty}{\sum}$ & & & \\
\hline $\begin{array}{l}\text { Non-Music } \\
\text { Workshops }\end{array}$ & 4 & 44 & 36 & 35 & 8 & 12 & 139 & $57.4 \%$ & .068 \\
\hline $\begin{array}{l}\text { On-Campus } \\
\text { Inservice }\end{array}$ & 4 & 41 & 34 & 31 & 6 & 7 & 123 & $50.8 \%$ & .162 \\
\hline $\begin{array}{l}\text { Non-Music } \\
\text { Conferences }\end{array}$ & 3 & 42 & 27 & 36 & 6 & 5 & 119 & $49.1 \%$ & .125 \\
\hline $\begin{array}{l}\text { District } \\
\text { Sponsored } \\
\text { Workshops }\end{array}$ & 2 & 37 & 27 & 37 & 3 & 11 & 117 & $48.3 \%$ & .294 \\
\hline $\begin{array}{l}\text { County Office of } \\
\text { Ed. Workshops }\end{array}$ & 4 & 36 & 29 & 27 & 5 & 12 & 113 & $46.6 \%$ & .408 \\
\hline $\begin{array}{l}\text { Curriculum } \\
\text { Development } \\
\text { Meetings }\end{array}$ & 1 & 29 & 18 & 14 & 3 & 6 & 71 & $29.3 \%$ & .518 \\
\hline $\begin{array}{l}\text { Online/Distance } \\
\text { Learning }\end{array}$ & 2 & 19 & 19 & 14 & 2 & 4 & 60 & $24.7 \%$ & .758 \\
\hline $\begin{array}{l}\text { Beginning } \\
\text { Teacher Support } \\
\text { \& Assessment }\end{array}$ & 1 & 9 & 11 & 19 & 0 & 6 & 46 & $19.0 \%$ & .202 \\
\hline $\begin{array}{l}\text { Educational } \\
\text { Research }\end{array}$ & 2 & 19 & 8 & 10 & 4 & 2 & 45 & $18.5 \%$ & .462 \\
\hline $\begin{array}{l}\text { Service in a } \\
\text { Music } \\
\text { Organization }\end{array}$ & 1 & 11 & 6 & 4 & 0 & 4 & 26 & $10.7 \%$ & .430 \\
\hline $\begin{array}{l}\text { Additional } \\
\text { College } \\
\text { Coursework }\end{array}$ & 2 & 2 & 5 & 7 & 0 & 2 & 18 & $07.4 \%$ & .684 \\
\hline
\end{tabular}


Amount of District Reimbursement

\begin{tabular}{|c|c|c|c|c|c|c|c|c|c|}
\hline Activity & 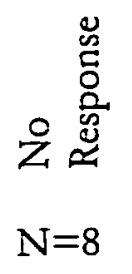 & $\begin{array}{c}\stackrel{\tilde{Z}}{Z} \\
\mathrm{~N}=78\end{array}$ & 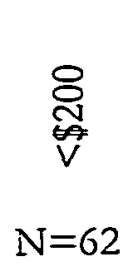 & 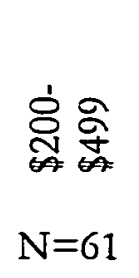 & 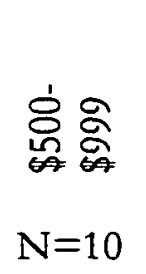 & $\begin{array}{c}\stackrel{\aleph}{\sum} \\
N=23\end{array}$ & $\begin{array}{c}\text { 㤩 } \\
\mathrm{N}=242\end{array}$ & 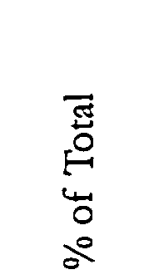 & $\begin{array}{l}\text { Sig. } \\
p<.10\end{array}$ \\
\hline $\begin{array}{l}\text { Service as a } \\
\text { Mentor Teacher }\end{array}$ & 0 & 1 & 6 & 4 & 1 & 2 & 14 & $05.7 \%$ & .974 \\
\hline $\begin{array}{l}\text { Peer Mentoring } \\
\text { Activities }\end{array}$ & 0 & 5 & 1 & 3 & 0 & 3 & 12 & $04.9 \%$ & .426 \\
\hline $\begin{array}{l}\text { Being a Guest } \\
\text { Teacher/Clinician }\end{array}$ & 0 & 3 & 2 & 1 & 0 & 1 & 7 & $02.8 \%$ & .632 \\
\hline $\begin{array}{l}\text { New Music } \\
\text { Reading Sessions }\end{array}$ & 1 & 2 & 1 & 0 & 1 & 1 & 6 & $02.4 \%$ & .654 \\
\hline Music Workshops & 0 & 2 & 1 & 0 & 0 & 1 & 4 & $01.6 \%$ & $-a^{a}$ \\
\hline $\begin{array}{l}\text { Attendance at } \\
\text { Concerts }\end{array}$ & 0 & 1 & 2 & 1 & 0 & 0 & 4 & $01.6 \%$ & $-\ldots a$ \\
\hline $\begin{array}{l}\text { Music } \\
\text { Conferences }\end{array}$ & 0 & 1 & 0 & 0 & 0 & 2 & 3 & $01.2 \%$ & $\ldots a$ \\
\hline $\begin{array}{l}\text { Hosting a Guest } \\
\text { Teacher/Clinician }\end{array}$ & 0 & 0 & 1 & 1 & 0 & 0 & 2 & $00.8 \%$ & $\ldots$ \\
\hline $\begin{array}{l}\text { Observing Other } \\
\text { Rehearsals }\end{array}$ & 0 & 1 & 0 & 0 & 0 & 0 & 1 & $00.4 \%$ & $--^{a}$ \\
\hline
\end{tabular}

${ }^{2}$ Sample size was $<5$

Table 51 presents the cross tabulations between the least valuable professional growth activities identified by the respondents with the survey population's number of high school instrumental music teachers in their district.

Table 51 reveals cross tabulations between the least valuable professional growth activities identified by the respondents with the survey population's number of high school instrumental music teachers in the district did not produce any significant differences between the two variables. 
Practically significant $(p=.113)$ is the data from County Office of Education Workshops.

Teachers from districts with 5-19 music teachers chose County Office of Education

Workshops more often as a least valuable activity while the other sub-groups chose it less often.

Table 51

Least Valuable Professional Growth Activities by the Number of High School Instrumental Music Teachers in the District

\begin{tabular}{|c|c|c|c|c|c|c|c|c|c|}
\hline \multirow{2}{*}{ Activity } & \multicolumn{7}{|c|}{ HS Instrumental Music Teachers in the District } & \multirow[b]{2}{*}{ 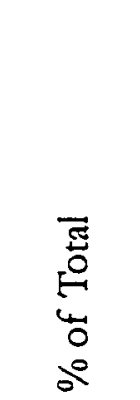 } & \multirow[b]{2}{*}{ 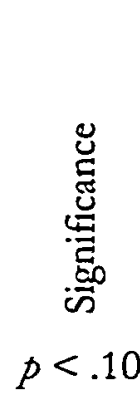 } \\
\hline & $\begin{array}{c}1 \\
N=48\end{array}$ & $\begin{array}{c}+ \\
\stackrel{+}{N} \\
N=62\end{array}$ & $\begin{array}{l}\hat{a} \\
\text { in } \\
N=58\end{array}$ & 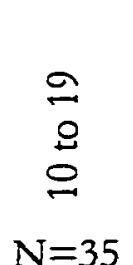 & $\begin{array}{l}\stackrel{\Xi}{0} \\
\stackrel{\Xi}{J} \\
\text { ○ } \\
N=35\end{array}$ & 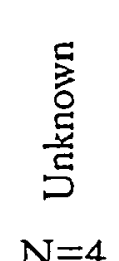 & 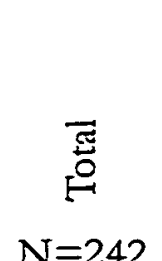 & & \\
\hline $\begin{array}{l}\text { Non-Music } \\
\text { Workshops }\end{array}$ & 26 & 34 & 37 & 21 & 18 & 3 & 139 & $57.4 \%$ & .886 \\
\hline $\begin{array}{l}\text { On-Campus } \\
\text { Inservice }\end{array}$ & 22 & 32 & 30 & 19 & 18 & 2 & 123 & $50.8 \%$ & .478 \\
\hline $\begin{array}{l}\text { Non-Music } \\
\text { Conferences }\end{array}$ & 29 & 27 & 29 & 18 & 16 & 0 & 119 & $49.1 \%$ & .692 \\
\hline $\begin{array}{l}\text { District Sponsored } \\
\text { Workshops }\end{array}$ & 26 & 37 & 26 & 17 & 10 & 1 & 117 & $48.3 \%$ & .411 \\
\hline $\begin{array}{l}\text { County Office of Ed. } \\
\text { Workshops }\end{array}$ & 20 & 24 & 35 & 17 & 13 & 4 & 113 & $46.6 \%$ & .113 \\
\hline $\begin{array}{l}\text { Curriculum } \\
\text { Development } \\
\text { Meetings }\end{array}$ & 17 & 17 & 19 & 6 & 11 & 1 & 71 & $29.3 \%$ & .625 \\
\hline $\begin{array}{l}\text { Online/Distance } \\
\text { Learning }\end{array}$ & 11 & 14 & 18 & 7 & 9 & 1 & 60 & $24.7 \%$ & .714 \\
\hline $\begin{array}{l}\text { Beginning Teacher } \\
\text { Support \& } \\
\text { Assessment }\end{array}$ & 11 & 12 & 9 & 6 & 5 & 3 & 46 & $19.0 \%$ & .103 \\
\hline
\end{tabular}


HS Instrumental Music Teachers in the District

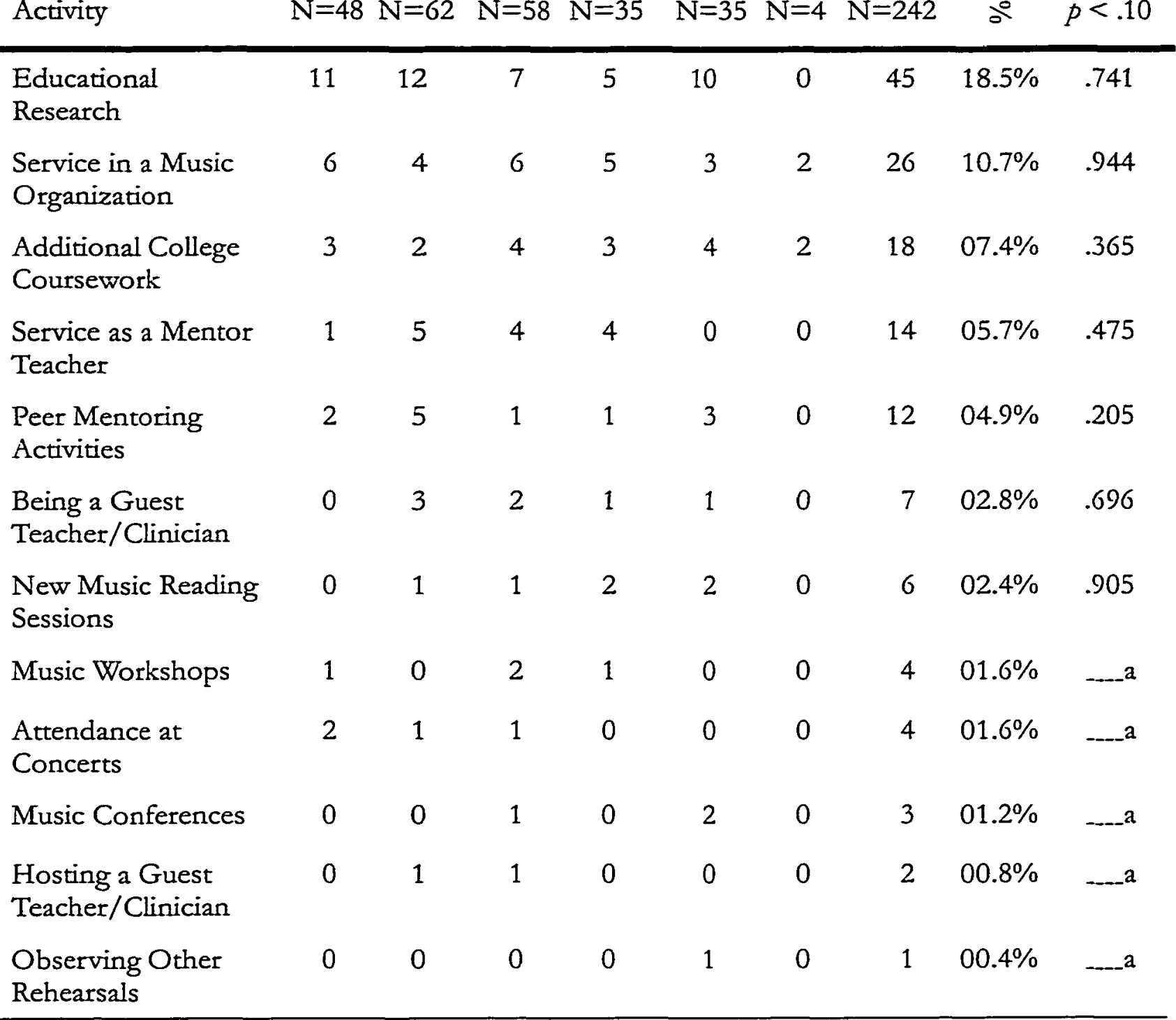

${ }^{2}$ Sample size was $<5$

Table 52 displays cross tabulations between the least valuable professional growth activities identified by the respondents with the survey population's school size. The data indicate that there is one activity in which the selections of the respondents vary significantly 
$(p<10)$ from the average according to school size. This activity is New Music Reading

Sessions.

Table 52

Least Valuable Professional Growth Activities by School Size

\begin{tabular}{|c|c|c|c|c|c|c|c|c|c|}
\hline \multirow[b]{3}{*}{ Activity } & \multicolumn{6}{|c|}{ School Size } & \multirow{3}{*}{$\begin{array}{c}\text { 吾 } \\
\mathrm{N}=241\end{array}$} & \multirow{3}{*}{ 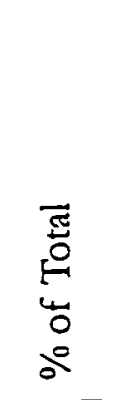 } & \multirow{3}{*}{ 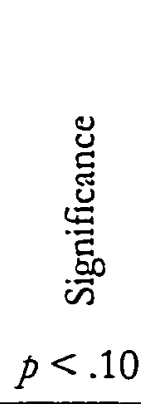 } \\
\hline & 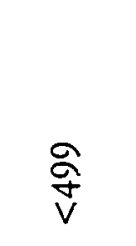 & $\begin{array}{l}2 \\
\hat{a} \\
\stackrel{8}{8} \\
8\end{array}$ & $\begin{array}{l}\stackrel{2}{\dot{\ddagger}} \\
\stackrel{8}{8} \\
8 \\
8\end{array}$ & 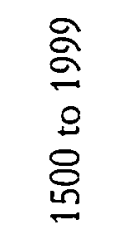 & 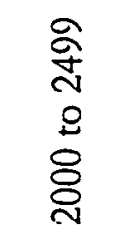 & 䇂 & & & \\
\hline & $\mathrm{N}=16$ & $\mathrm{~N}=18$ & $\mathrm{~N}=31$ & $\mathrm{~N}=53$ & $N=62$ & $N=61$ & & & \\
\hline $\begin{array}{l}\text { Non-Music } \\
\text { Workshops }\end{array}$ & 8 & 6 & 22 & 27 & 37 & 39 & 139 & $57.4 \%$ & .758 \\
\hline $\begin{array}{l}\text { On-Campus } \\
\text { Inservice }\end{array}$ & 6 & 7 & 16 & 32 & 32 & 30 & 123 & $50.8 \%$ & .496 \\
\hline $\begin{array}{l}\text { Non-Music } \\
\text { Conferences }\end{array}$ & 10 & 7 & 21 & 19 & 27 & 35 & 119 & $49.1 \%$ & .165 \\
\hline $\begin{array}{l}\text { District } \\
\text { Sponsored } \\
\text { Workshops }\end{array}$ & 8 & 7 & 17 & 27 & 30 & 28 & 117 & $48.3 \%$ & .605 \\
\hline $\begin{array}{l}\text { County Office } \\
\text { of Ed. } \\
\text { Workshops }\end{array}$ & 7 & 7 & 17 & 27 & 33 & 22 & 113 & $46.6 \%$ & .244 \\
\hline $\begin{array}{l}\text { Curriculum } \\
\text { Development } \\
\text { Meetings }\end{array}$ & 3 & 4 & 8 & 21 & 18 & 17 & 71 & $29.3 \%$ & .735 \\
\hline $\begin{array}{l}\text { Online/Distance } \\
\text { Learning }\end{array}$ & 6 & 4 & 8 & 12 & 17 & 13 & 60 & $24.7 \%$ & .362 \\
\hline $\begin{array}{l}\text { Beginning } \\
\text { Teacher Support } \\
\text { \& Assessment }\end{array}$ & 2 & 5 & 4 & 12 & 9 & 14 & 46 & $19.0 \%$ & .165 \\
\hline $\begin{array}{l}\text { Educational } \\
\text { Research }\end{array}$ & 6 & 1 & 6 & 9 & 12 & 11 & 45 & $18.5 \%$ & .266 \\
\hline $\begin{array}{l}\text { Service in a Music } \\
\text { Organization }\end{array}$ & 4 & 2 & 3 & 6 & 5 & 6 & 26 & $10.7 \%$ & .742 \\
\hline
\end{tabular}




\begin{tabular}{|c|c|c|c|c|c|c|c|c|c|}
\hline \multirow[b]{3}{*}{ Ictivity } & \multicolumn{6}{|c|}{ School Size } & \multirow{3}{*}{$\begin{array}{c}\bar{\Xi} \\
N=241\end{array}$} & \multirow{3}{*}{ 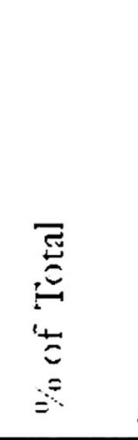 } & \multirow{3}{*}{ 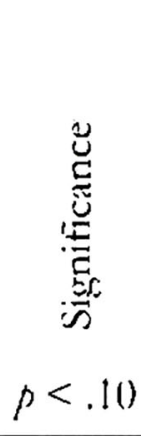 } \\
\hline & $\stackrel{\text { 亏 }}{\mathrm{g}}$ & 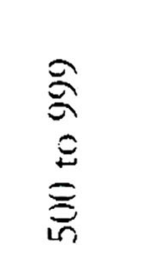 & 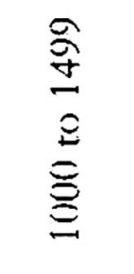 & 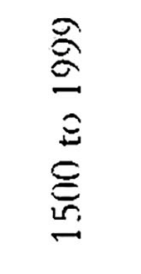 & 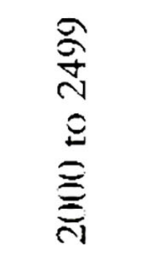 & $\stackrel{ \pm}{\Xi}$ & & & \\
\hline & $N=16$ & $N=18$ & $N=31$ & $N=53$ & $N=62$ & $N=61$ & & & \\
\hline $\begin{array}{l}\text { Iolitional } \\
\text { College } \\
\text { Coursework }\end{array}$ & 2 & 1 & 6 & 3 & 5 & 1 & 18 & $(17.4 \%$ & .785 \\
\hline $\begin{array}{l}\text { Service as a } \\
\text { Mentor Teacher }\end{array}$ & () & 2 & 3 & 2 & 6 & 1 & 14 & 05.71110 & .794 \\
\hline $\begin{array}{l}\text { Pecr Mentoring } \\
\text { Activities }\end{array}$ & 1 & 0 & 3 & 5 & 2 & 1 & 12 & $04.9 \%$ & .700 \\
\hline $\begin{array}{l}\text { Being a Guest } \\
\text { Teacher/Clinician }\end{array}$ & 1 & 0 & 1 & 2 & 2 & 1 & 7 & $02.8 \%$ & .437 \\
\hline $\begin{array}{l}\text { New Music } \\
\text { Reading Sessions }\end{array}$ & 0 & () & 0 & 0 & 4 & 1 & 5 & $(12.6 \% 1 \%$ & .099 \\
\hline $\begin{array}{l}\text { Music } \\
\text { Workshops }\end{array}$ & 0 & 1 & 1 & 2 & 0 & 0 & 4 & $011.6 \%$ & $-\ldots$ \\
\hline $\begin{array}{l}\text { Artendance at } \\
\text { Concerts }\end{array}$ & 1 & 1 & 1 & 1 & 0 & 0 & 4 & $(01.6 \% \%$ & $\ldots$ \\
\hline $\begin{array}{l}\text { Music } \\
\text { Conferences }\end{array}$ & () & 1 & 0 & 0 & 0 & 2 & 3 & $01.2 \%$ & $\ldots a$ \\
\hline $\begin{array}{l}\text { Hosting a Guest } \\
\text { Teacher/Clinician }\end{array}$ & () & 0 & 0 & 1 & 0 & 1 & 2 & $(00.8 \%$ & $---a$ \\
\hline $\begin{array}{l}\text { ()bserving } \\
\text { ()ther Rehearsals }\end{array}$ & 0 & () & 0 & 0 & 0 & 1 & 1 & $(1)(0.4 \%$ & $-\cdots a$ \\
\hline
\end{tabular}

"Sample size was $<5$

Only 2.6\% of the survey respondents selected New Music Reading Sessions als a least valuable activity: Yet, teachers with school populations of $2000-2499$ selected New Music Reading Scssions as a least valuable activity more than the arerage of the group. Teachers with school populations of 50(1)-1999 and greater than 2500 students selected this activity less often than the group arerage. 
Table 53 shows cross tabulations between the least valuable professional growth activities identified by the respondents with the survey population's school location. The data indicate that there is one activity in which the selections of the respondents vary significantly $(p<.10)$ from the average according to the location of the school. This activity is Beginning Teacher Support and Assessment.

Teachers in rural and urban schools chose Beginning Teacher Support and Assessment as a least valuable activity by more than the $19 \%$ over the group average of $19 \%$. Teachers in suburban school chose Beginning Teacher Support and Assessment as a least valuable activity less than the group average.

\section{Table 53}

\section{Least Valuable Professional Growth Activities by School Location}

\begin{tabular}{|c|c|c|c|c|c|c|}
\hline \multirow[b]{3}{*}{ Activity } & \multicolumn{3}{|c|}{ School Location } & \multirow{3}{*}{$\begin{array}{c}\text { Total } \\
\mathrm{N}=242\end{array}$} & \multirow{3}{*}{ 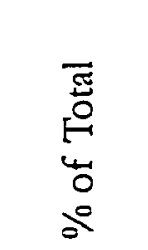 } & \multirow{3}{*}{$\begin{array}{c}\text { Significance } \\
p<.10\end{array}$} \\
\hline & Rural & Suburban & Urban & & & \\
\hline & $\mathrm{N}=56$ & $N=117$ & $N=69$ & & & \\
\hline Non-Music Workshops & 31 & 74 & 34 & 139 & $57.4 \%$ & .558 \\
\hline On-Campus Inservice & 25 & 64 & 34 & 123 & $50.8 \%$ & .358 \\
\hline $\begin{array}{l}\text { Non-Music } \\
\text { Conferences }\end{array}$ & 29 & 58 & 32 & 119 & $49.1 \%$ & .328 \\
\hline $\begin{array}{l}\text { District Sponsored } \\
\text { Workshops }\end{array}$ & 28 & 56 & 33 & 117 & $48.3 \%$ & .345 \\
\hline $\begin{array}{l}\text { County Office of Ed. } \\
\text { Workshops }\end{array}$ & 27 & 59 & 27 & 113 & $46.6 \%$ & .496 \\
\hline $\begin{array}{l}\text { Curriculum } \\
\text { Development Meetings }\end{array}$ & 11 & 33 & 27 & 71 & $29.3 \%$ & .450 \\
\hline $\begin{array}{l}\text { Online/Distance } \\
\text { Learning }\end{array}$ & 13 & 28 & 19 & 60 & $24.7 \%$ & .517 \\
\hline $\begin{array}{l}\text { Beginning Teacher } \\
\text { Support \& Assessment }\end{array}$ & 14 & 17 & 15 & 46 & $19.0 \%$ & .070 \\
\hline
\end{tabular}




\begin{tabular}{|c|c|c|c|c|c|c|}
\hline \multirow[b]{3}{*}{ Activity } & \multicolumn{3}{|c|}{ School Location } & \multirow{3}{*}{$\begin{array}{c}\text { Total } \\
N=242\end{array}$} & \multirow{3}{*}{\begin{tabular}{l} 
焉 \\
\multirow{4}{0}{} \\
0 \\
0
\end{tabular}} & \multirow{3}{*}{$\begin{array}{l}\text { Significance } \\
\qquad p<.10\end{array}$} \\
\hline & & & & & & \\
\hline & $N=56$ & $N=117$ & $N=69$ & & & \\
\hline Educational Research & 12 & 17 & 16 & 45 & $18.5 \%$ & .906 \\
\hline $\begin{array}{l}\text { Service in a Music } \\
\text { Organization }\end{array}$ & 7 & 11 & 8 & 26 & $10.7 \%$ & .595 \\
\hline $\begin{array}{l}\text { Additional College } \\
\text { Coursework }\end{array}$ & 4 & 7 & 7 & 18 & $07.4 \%$ & .579 \\
\hline $\begin{array}{l}\text { Service as a Mentor } \\
\text { Teacher }\end{array}$ & 3 & 7 & 4 & 14 & $05.7 \%$ & .360 \\
\hline $\begin{array}{l}\text { Peer Mentoring } \\
\text { Activities }\end{array}$ & 4 & 3 & 5 & 12 & $04.9 \%$ & .250 \\
\hline $\begin{array}{l}\text { Being a Guest } \\
\text { Teacher/Clinician }\end{array}$ & 2 & 2 & 3 & 7 & $02.8 \%$ & .931 \\
\hline $\begin{array}{l}\text { New Music Reading } \\
\text { Session }\end{array}$ & 0 & 4 & 2 & 6 & $02.4 \%$ & .833 \\
\hline Music Workshops & 3 & 1 & 0 & 4 & $01.6 \%$ & $\ldots$ \\
\hline Attendance at Concerts & 2 & 1 & 1 & 4 & $01.6 \%$ & $\ldots$ \\
\hline Music Conferences & 1 & 2 & 0 & 3 & $01.2 \%$ & $\ldots \ldots$ \\
\hline $\begin{array}{l}\text { Hosting a Guest } \\
\text { Teacher/Clinician }\end{array}$ & 1 & 1 & 0 & 2 & $00.8 \%$ & $\ldots$ \\
\hline $\begin{array}{l}\text { Observing Other } \\
\text { Rehearsals }\end{array}$ & 0 & 0 & 1 & 1 & $00.4 \%$ & $\ldots a$ \\
\hline
\end{tabular}

${ }^{2}$ Sample size was $<5$

Table 54 illustrate cross tabulations between the least valuable professional growth activities identified by the respondents with the survey population's number of students in the instrumental program. The data indicate that there are no significant differences $(\phi<.10)$ among any of the variables. 
Table 54

Least Valuable Professional Growth Activities by Number of Students in the Program

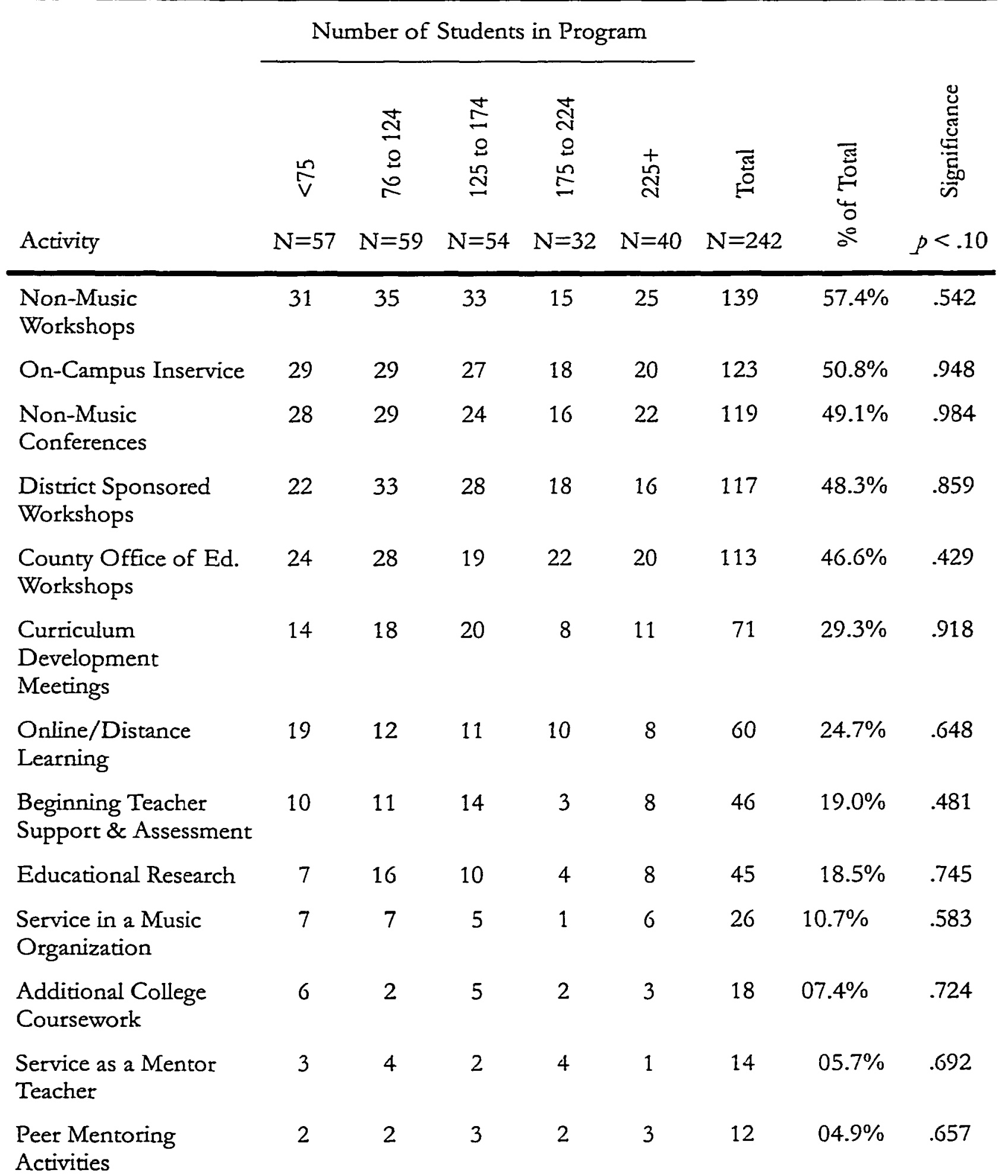




\begin{tabular}{|c|c|c|c|c|c|c|c|c|}
\hline \multirow{2}{*}{ Activity } & \multicolumn{5}{|c|}{ Number of Students in Program } & \multirow[b]{2}{*}{$\begin{array}{c}\text { స్ } \\
\mathrm{N}=242\end{array}$} & \multirow[b]{2}{*}{ 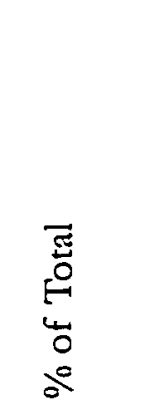 } & \multirow[b]{2}{*}{ 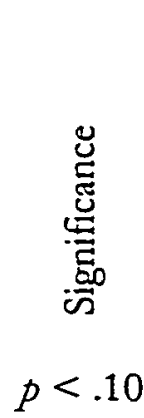 } \\
\hline & $\begin{array}{c}\stackrel{2}{V} \\
N=57\end{array}$ & 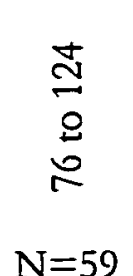 & $\begin{array}{c}\stackrel{\Xi}{\Xi} \\
\stackrel{5}{\Xi} \\
\stackrel{\Xi}{\Xi} \\
N=54\end{array}$ & $\begin{array}{c}\stackrel{J}{J} \\
\stackrel{2}{*} \\
\stackrel{2}{\Xi} \\
N=32\end{array}$ & $\begin{array}{c}\stackrel{+}{\mathrm{N}} \\
N=40\end{array}$ & & & \\
\hline $\begin{array}{l}\text { Being a Guest } \\
\text { Teacher/Clinician }\end{array}$ & 2 & 1 & 1 & 1 & 2 & 7 & $02.8 \%$ & .642 \\
\hline $\begin{array}{l}\text { New Music Reading } \\
\text { Sessions }\end{array}$ & 1 & 2 & 0 & 1 & 2 & 6 & $02.4 \%$ & 1.000 \\
\hline Music Workshops & 1 & 1 & 1 & 0 & 1 & 4 & $01.6 \%$ & $\ldots$ \\
\hline $\begin{array}{l}\text { Attendance at } \\
\text { Concerts }\end{array}$ & 2 & 1 & 1 & 0 & 0 & 4 & $01.6 \%$ & $\ldots a$ \\
\hline Music Conferences & 1 & 1 & 1 & 0 & 0 & 3 & $01.2 \%$ & $\ldots$ \\
\hline $\begin{array}{l}\text { Hosting a Guest } \\
\text { Teacher/Clinician }\end{array}$ & 1 & 0 & 1 & 0 & 0 & 2 & $00.8 \%$ & $---a^{a}$ \\
\hline $\begin{array}{l}\text { Observing Other } \\
\text { Rehearsals }\end{array}$ & 0 & 0 & 1 & 0 & 0 & 1 & $00.4 \%$ & $\ldots$ \\
\hline
\end{tabular}

${ }^{2}$ Sample size was $<5$

Table 55 presents cross tabulations between the least valuable professional growth activities identified by the respondents with the survey population's sex. The data indicate that there are no significant differences $(p<.10)$ between the two variables. 
Table 55

Least Valuable Professional Growth Activities by Sex

\begin{tabular}{|c|c|c|c|c|c|c|}
\hline \multirow[b]{3}{*}{ Activity } & \multicolumn{3}{|c|}{ Sex } & \multirow[b]{2}{*}{ Total } & \multirow{3}{*}{ 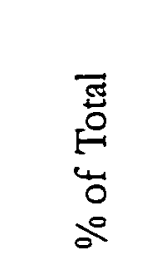 } & \multirow{3}{*}{$\begin{array}{l}\text { Significance } \\
p<.10\end{array}$} \\
\hline & Male & Female & $\begin{array}{c}\text { No } \\
\text { Response }\end{array}$ & & & \\
\hline & $N=197$ & $N=42$ & $N=3$ & $N=242$ & & \\
\hline Non-Music Workshops & 114 & 24 & 1 & 139 & $57.4 \%$ & .401 \\
\hline On-Campus Inservice & 102 & 19 & 2 & 123 & $50.8 \%$ & .830 \\
\hline $\begin{array}{l}\text { Non-Music } \\
\text { Conferences }\end{array}$ & 101 & 17 & 1 & 119 & $49.1 \%$ & .158 \\
\hline $\begin{array}{l}\text { District Sponsored } \\
\text { Workshops }\end{array}$ & 97 & 18 & 2 & 117 & $48.3 \%$ & .773 \\
\hline $\begin{array}{l}\text { County Office of Ed. } \\
\text { Workshops }\end{array}$ & 96 & 16 & 1 & 113 & $46.6 \%$ & .883 \\
\hline $\begin{array}{l}\text { Curriculum } \\
\text { Development Meetings }\end{array}$ & 63 & 7 & 1 & 71 & $29.3 \%$ & .370 \\
\hline $\begin{array}{l}\text { Online/Distance } \\
\text { Learning }\end{array}$ & 46 & 13 & 1 & 60 & $24.7 \%$ & .744 \\
\hline $\begin{array}{l}\text { Beginning Teacher } \\
\text { Support \& Assessment }\end{array}$ & 36 & 9 & 1 & 46 & $19.0 \%$ & .711 \\
\hline Educational Research & 35 & 9 & 1 & 45 & $18.5 \%$ & .388 \\
\hline $\begin{array}{l}\text { Service in a Music } \\
\text { Organization }\end{array}$ & 19 & 7 & 0 & 26 & $10.7 \%$ & .565 \\
\hline $\begin{array}{l}\text { Additional College } \\
\text { Coursework }\end{array}$ & 15 & 3 & 0 & 18 & $07.4 \%$ & .445 \\
\hline $\begin{array}{l}\text { Service as a Mentor } \\
\text { Teacher }\end{array}$ & 12 & 2 & 0 & 14 & $05.7 \%$ & .788 \\
\hline $\begin{array}{l}\text { Peer Mentoring } \\
\text { Activities }\end{array}$ & 9 & 2 & 1 & 12 & $04.9 \%$ & .983 \\
\hline $\begin{array}{l}\text { Being a Guest } \\
\text { Teacher/Clinician }\end{array}$ & 3 & 4 & 0 & 7 & $02.8 \%$ & .184 \\
\hline $\begin{array}{l}\text { New Music Reading } \\
\text { Session }\end{array}$ & 6 & 0 & 0 & 6 & $02.4 \%$ & $\ldots$ \\
\hline Music Workshops & 4 & 0 & 0 & 4 & $01.6 \%$ & $\ldots$ \\
\hline
\end{tabular}




\begin{tabular}{|c|c|c|c|c|c|c|}
\hline \multirow[b]{3}{*}{ Activity } & \multicolumn{3}{|c|}{ Sex } & \multirow[b]{2}{*}{ Total } & \multirow{3}{*}{$\begin{array}{c}\text { 至 } \\
0 \\
0 \\
0 \\
0 \\
0\end{array}$} & \multirow{3}{*}{$\begin{array}{c}\text { Significance } \\
p<.10\end{array}$} \\
\hline & Male & Female & $\begin{array}{c}\text { No } \\
\text { Response }\end{array}$ & & & \\
\hline & $N=197$ & $N=42$ & $N=3$ & $N=242$ & & \\
\hline $\begin{array}{l}\text { Attendance at } \\
\text { Concerts }\end{array}$ & 4 & 0 & 0 & 4 & $01.6 \%$ & $\ldots$ \\
\hline Music Conferences & 2 & 1 & 0 & 3 & $01.2 \%$ & $\ldots$ \\
\hline $\begin{array}{l}\text { Hosting a Guest } \\
\text { Teacher/Clinician }\end{array}$ & 2 & 0 & 0 & 2 & $00.8 \%$ & $\ldots$ \\
\hline $\begin{array}{l}\text { Observing Other } \\
\text { Rehearsals }\end{array}$ & 1 & 0 & 0 & 1 & $00.4 \%$ & $\ldots$ \\
\hline
\end{tabular}

${ }^{2}$ Sample size was $<5$

Data from the activity Non-Music Conferences indicate that there is almost a significance $(p=158)$ between selection rates of males and females. Males chose Non-Music Conferences as a least valuable activity slightly more often, while females chose this activity $9 \%$ less often.

Table 56 indicates cross tabulations between the least valuable professional growth activities identified by the respondents with the survey population's race. The data indicate that there are no significant differences $(p<.10)$ between the variables.

Practically significant $(p=.143)$ is the data from County Office of Education Workshops. This activity indicated that those teachers who did not indicate a race chose this activity more often as a least valuable activity than the rest of the respondents. 
Table 56

Least Valuable Professional Growth Activities by Race

\begin{tabular}{|c|c|c|c|c|c|c|}
\hline \multirow[b]{3}{*}{ Activity } & \multicolumn{3}{|c|}{ Race } & \multirow[b]{2}{*}{ Total } & \multirow{3}{*}{ 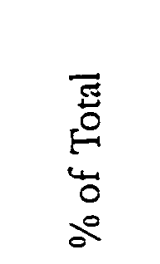 } & \multirow{3}{*}{$\begin{array}{l}\text { Significance } \\
\qquad p<.10\end{array}$} \\
\hline & Caucasian & $\begin{array}{c}\text { Non- } \\
\text { Caucasian }\end{array}$ & $\begin{array}{c}\text { No } \\
\text { Response }\end{array}$ & & & \\
\hline & $N=149$ & $N=24$ & $\mathrm{~N}=69$ & $N=242$ & & \\
\hline $\begin{array}{l}\text { Non-Music } \\
\text { Workshops }\end{array}$ & 89 & 15 & 35 & 139 & $57.4 \%$ & .925 \\
\hline $\begin{array}{l}\text { On-Campus } \\
\text { Inservice }\end{array}$ & 77 & 8 & 38 & 123 & $50.8 \%$ & .546 \\
\hline $\begin{array}{l}\text { Non-Music } \\
\text { Conferences }\end{array}$ & 80 & 11 & 28 & 119 & $49.1 \%$ & .231 \\
\hline $\begin{array}{l}\text { District Sponsored } \\
\text { Workshops }\end{array}$ & 70 & 8 & 39 & 117 & $48.3 \%$ & .543 \\
\hline $\begin{array}{l}\text { County Office of Ed. } \\
\text { Workshops }\end{array}$ & 69 & 10 & 34 & 113 & $46.6 \%$ & .143 \\
\hline $\begin{array}{l}\text { Curriculum } \\
\text { Development } \\
\text { Meetings }\end{array}$ & 50 & 7 & 14 & 71 & $29.3 \%$ & .336 \\
\hline $\begin{array}{l}\text { Online/Distance } \\
\text { Learning }\end{array}$ & 35 & 8 & 17 & 60 & $24.7 \%$ & .689 \\
\hline $\begin{array}{l}\text { Beginning Teacher } \\
\text { Support \& } \\
\text { Assessment }\end{array}$ & 27 & 4 & 15 & 46 & $19.0 \%$ & .539 \\
\hline Educational Research & 28 & 3 & 14 & 45 & $18.5 \%$ & .631 \\
\hline $\begin{array}{l}\text { Service in a Music } \\
\text { Organization }\end{array}$ & 16 & 1 & 9 & 26 & $10.7 \%$ & .346 \\
\hline $\begin{array}{l}\text { Additional College } \\
\text { Coursework }\end{array}$ & 13 & 2 & 3 & 18 & $07.4 \%$ & .905 \\
\hline $\begin{array}{l}\text { Service as a Mentor } \\
\text { Teacher }\end{array}$ & 10 & 1 & 3 & 14 & $05.7 \%$ & .196 \\
\hline $\begin{array}{l}\text { Peer Mentoring } \\
\text { Activities }\end{array}$ & 8 & 2 & 2 & 12 & $04.9 \%$ & .442 \\
\hline
\end{tabular}




\begin{tabular}{|c|c|c|c|c|c|c|}
\hline \multirow[b]{3}{*}{ Activity } & \multicolumn{3}{|c|}{ Race } & \multirow[b]{2}{*}{ Total } & \multirow{3}{*}{ 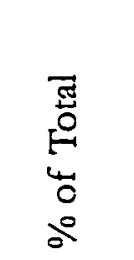 } & \multirow{3}{*}{$\begin{array}{l}\text { Significance } \\
\qquad p<.10\end{array}$} \\
\hline & Caucasian & $\begin{array}{c}\text { Non- } \\
\text { Caucasian }\end{array}$ & $\begin{array}{c}\text { No } \\
\text { Response }\end{array}$ & & & \\
\hline & $N=149$ & $\mathrm{~N}=24$ & $N=69$ & $N=242$ & & \\
\hline $\begin{array}{l}\text { Being a Guest } \\
\text { Teacher/Clinician }\end{array}$ & 5 & 1 & 1 & 7 & $02.8 \%$ & .837 \\
\hline $\begin{array}{l}\text { New Music Reading } \\
\text { Session }\end{array}$ & 4 & 1 & 1 & 6 & $02.4 \%$ & .223 \\
\hline Music Workshops & 3 & 0 & 1 & 4 & $01.6 \%$ & $\ldots$ \\
\hline $\begin{array}{l}\text { Attendance at } \\
\text { Concerts }\end{array}$ & 4 & 0 & 0 & 4 & $01.6 \%$ & $\ldots$ \\
\hline Music Conferences & 3 & 0 & 0 & 3 & $01.2 \%$ & $\ldots$ \\
\hline $\begin{array}{l}\text { Hosting a Guest } \\
\text { Teacher/Clinician }\end{array}$ & 0 & 2 & 0 & 2 & $00.8 \%$ & $\ldots$ \\
\hline $\begin{array}{l}\text { Observing Other } \\
\text { Rehearsals }\end{array}$ & 1 & 0 & 0 & 1 & $00.4 \%$ & $\ldots a$ \\
\hline
\end{tabular}

${ }^{a}$ Sample size was $<5$

Part Eight: Comments to Organizations That Provide Professional Growth Activities for High

\section{$\underline{\text { School Instrumental Music Teachers }}$}

The final part of the survey instrument (see Appendix B, part IV) asked the respondents to write brief comments directed towards the organizations that provide professional growth activities for high school instrumental music teachers. Comments were provided by 108 out of 242 respondents which generated a response rate of $44.6 \%$.

Table 57 preserits the number of different types of comments provided by the survey respondents. The comments fell into six general areas: (a) suggestions and ideas for improvement, (b) criticism and areas of concern, (c) praise and satisfaction with the organizations, (d) encouragement for others to get involved, (e) warnings to the 
organizations, and ( $t$ ) inquiries. The percentages do not total $100 \%$ because many comments included statements that were applicable to more than one activity.

Table 57

Comments for Professional Growth Organizations

\begin{tabular}{lcc}
\hline Comment Type & Amount & Percentage \\
\hline Suggestions & 65 & $60.1 \%$ \\
Criticisms & 23 & $21.2 \%$ \\
Praise & 16 & $14.8 \%$ \\
Encouragement & 3 & $02.7 \%$ \\
Warnings & 2 & $01.8 \%$ \\
Inquiry & 1 & $00.9 \%$ \\
Total & 108 & \\
\hline
\end{tabular}

Suggestions to the organizations ranged from "developing more contacts with 'working' professional musicians and include these highly skilled players in our process" to "I believe all conferences should offer sessions on the expressive qualities of making music." Many comments focused on needs of new teachers. One teacher asked "How about seminars for new music teachers? The duties are enormous and we need ideas for discipline, fund-raising, accounting, etc." A complete listing of all the comments may be found in Appendix E.

One teacher stated a need for more mentor teachers while another teacher found that "organized mentoring sessions have seemed to me to be contrived." Another teacher thought that organizations should "subsidize retired (directors) traveling to remote areas."

While there were 16 comments that praised the music organizations, there were 23 criticisms of those same groups. The comments were directed at all of the major music 
organizations in California including CMEA, SCSBOA, and CBDA. Comments indicated that "MENC and CMEA are wonderful organizations and provide service to our music education community" and "CBDA has been the best conferences for me for the last 25 years." Another teacher wrote, "I enjoyed (the) conferences that SCSBOA puts together. You're able to get a lot of information from many sources in a short amount of time." On the other hand, another director wrote, "At times many organizations can be unapproachable to inexperienced directors."

A majority of the criticisms and suggestions encourage professional organizations to provide more resources, materials, and conference sessions that can be used in the rehearsal immediately. "Leave theoretical approaches to music education to colleges - concentrate on the practical (how to)," wrote one director. Another stated "Get a reality check! Intonation of Professional Bassoonists' is not [a] majority priority. Be more demanding of what you expect we can learn! And (sic.) use in our classroom now."

Many directors expressed a desire for the organizations to become pro-active with arts education advocacy issues. One director warned, "These organizations are going to have to teach the teachers how to keep the arts alive in an environment that is increasingly relying only on standardized test scores to determine the success or failure of schools. It's scary."

Not all criticisms were directed toward the music organizations, and some were directed towards the school districts themselves. One director wrote, "(Teachers need) to find a way to get (from the) district or school financial support. Teachers do not make the money necessary to subsidize their programs."

While there are 23 criticisms, it is interesting to note that the survey population's suggestions and praises outweighed the criticisms by more than 3 to 1 . 


\section{Conclusion}

The data presented in chapter four cover a wide range of statistics. Over fifty tables present basic demographics, mean score averages and multiple cross tabulations of variables. The demographic data reveal numerous, clear, and predictable patterns of choice and preference concerning professional growth activities of high school instrumental music teachers. Cross-referenced with a wide variety of demographic information and viewed from many perspectives, the information obtained from the respondents reveals many patterns and opinions regarding the professional growth landscape.

Discussion of the analysis, conclusions of the research findings and recommendations for further research study are presented in chapter five. 


\title{
Chapter 5
}

\section{SUMMARY, CONCLUSIONS AND RECOMMENDATIONS}

\author{
Summary \\ Developing a teacher's skills and knowledge beyond initial certification is becoming \\ increasingly important to the educational community. Since the passage of SB 813 in 1983, a \\ significant change has occurred in the professional lives of teachers by ending "lifetime" \\ credentialing in California. Now, teachers who earned their credential after August 31, 1985 \\ must show evidence of completing 150 hours of professional growth activities every five \\ years. This requirement applies to all teachers who hold credentials issued after August 31, \\ 1985 , including teachers of instrumental music. \\ This study investigated what professional growth activities public high school \\ instrumental music teachers in California utilize to comply with the state mandated \\ professional growth requirement.
}

\section{The Problem}

High school instrumental music seachers in the state of California generally follow the mandate of the legislature as evidenced by the fact that $72.5 \%$ of the survey respondents have taught more than five years, which basically indicates that credentials are being renewed. The problem is that while high school instrumental teachers are completing professional growth requirements, there is no study of the types of professional growth activities 
employed, the types of activities that are effective, or the types of activities that are ineffective.

\section{The Purpose}

The purposes of this study were to examine the professional growth habits and needs of high school instrumental music teachers of California, and the effectiveness of current professional growth opportunities as perceived by those high school instrumental music teachers. In addition, this study examined the implications of professional growth opportunities for high school instrumental music teachers and for the state music education organizations that serve them.

\section{Research Questions}

This research study sought to answer the following questions:

1. What types of professional growth activities are high school instrumental music teachers attending in order to satisfy the 150 -hour state requirement needed to maintain the Professional Clear Single Subject Music Credential every five years?

2. What professional growth activities do high school instrumental music teachers find effective in meeting their professional growth needs, and what activities do they find ineffective?

3. To what extent do high school instrumental music teachers participate in nontraditional professional growth activities such as peer mentoring and music education research?

4. Is there a difference in professional growth activities and needs among high school instrumental music teachers who work in urban, rural, and suburban areas of the state? 
5. What are the implications of this study for the state music organizations such as the Southern California School Band and Orchestra Association (SCSBOA), the California Band Directors Association (CDBA), and the California Music Educators Association CMEA?

6. What are the implications for school district leaders such as principals, district administrators, and curriculum coordinators with regard to providing staff development for the high school instrumental music teachers?

\section{Delimitations of the Study}

The boundaries of this study are described below:

This study examines the professional growth habits of high school instrumental music teachers who hold various types of California state teaching credentials.

This study does not examine high school choral teachers or any other public school music teachers even though these credential holders are certified to teach high school instrumental music. Therefore, the results of this study may not be characterized as representative of any other group.

\section{Limitations of the Study}

This study was limited by the effort and interest in the topic of each respondent.

When using a survey instrument, there is often the risk that the respondent will report in a manner that they feel will best serve the interests of the survey questions. This type of desirable reporting runs the risk of obtaining data that is not reliable. While the instructions on the survey instrument clearly state that all responses are treated as confidential, the results are limited to the level of honesty that each respondent employs. 


\section{Design and Data Collection Procedures}

In this quantitative research study, data were collected through a mailed survey instrument. The questionnaire was designed to elicit answers to specific research questions regarding the professional growth habits and levels of professional growth effectiveness from public high school instrumental music teachers in the state of California. The survey instrument was field-tested and modified to achieve appropriate levels of validity and reliability.

This chapter presents selected findings based upon the data collected and the implications of those findings for high school instrumental music teachers, school administrators and professional music organizations that provide professional growth opportunities for these teachers.

\section{Selected Findings}

Based on the collected data, the following findings were considered significant:

1. Public high school instrumental music teachers use concert attendance, conferences, rehearsal observation, and having a guest clinician as their primary source for professional growth. These data contradict a study done by Patrick Gemma where he reported "teachers use the college or university as their primary source for professional growth" (Gemma, 1997, p. 217). This disagreement exists because the population in Gemma's study involved all types of teachers in California. This study was limited to California public high school instrumental teachers. In Gemma's study, teachers had access to a wide variety of university sponsored professional growth activities while the respondents in this study had access to a wide variety of non-university activities. This study found that less than half (45.9\%) had taken a University or College course during the past three years (Table 20) as opposed to 88\% for Music Conference Attendance and 57.9\% for Music Workshops. Even Non-Music 
Workshops (57.9\%) were attended by more high school instrumental music teachers than were university or college courses.

In addition, the survey population indicated that taking additional university or college courses was only somewhat effective as a professional growth activity $(M=3.80 \pm 1.03)$. The standard deviation of 1.03 indicates that responses ranged from somewhat ineffective to most effective (Table 22). These findings are supported by the data displayed in the most valuable and least valuable tables found in Chapter Four. Taking additional university coursework was indicated to be one of the top 3-5 most valuable activities by $27.2 \%$ of the respondents while only $7.4 \%$ found this activity to be one of the 3-5 least valuable activities.

2. The four most effective professional growth activities were chosen by at least $75 \%$ of the respondents. These were in order: (a) Having a Guest Clinician or Teacher, (b) Observing Other Rehearsals, (c) Music Conferences, and (d) Attendance at Concerts. These choices are displayed in Table 22 where the respondents were asked to rate each activity from section 3 of the survey instrument using a Likert scale of 1 (Least Effective) to 5 (Most Effective).

These data reinforce the qualitative responses found in section 2 of the survey where the respondents were asked to identify the one activity that provided the most benefit. The top four activities identified in writing were: (a) Music Conferences, (b) Hosting a Guest Clinician or Teacher, (c) Observing Other Rehearsals, and (d) Music Workshops (Table 21). In the Likert scale ratings (Table 22), attendance at Music Workshops was sixth overall.

3. Males dominate the profession of high school instrumental music teachers by more than four to one. The survey population was composed of $81.4 \%$ males, and $17.4 \%$ females; three respondents did not indicate either sex. 
4. Those respondents that chose to indicate their race as Caucasians outnumber those that chose to indicate non-Caucasians by more than six to one. The portion of the survey population that indicated their race as Caucasians were $61.6 \%$ with $9.9 \%$ indicating nonCaucasians, with a large number $(28.5 \%)$ who chose not to identify their race.

5. The data, both quantitative and qualitative, indicate that five professional growth activities are least effective or somewhat ineffective for high school instrumental music teachers. More than $56 \%$ of the respondents chose (a) Curriculum Development Meetings, (b) Non-Music Conferences, (c) Non-Music Workshops, (d) District-Sponsored Workshops, and (e) On-Campus Inservice as being somewhat ineffective or least effective on the fivepoint Likert scale (Table 22). In addition, $20 \%$ or more of the respondents also identified ( $f$ ) Beginning Teacher Support and Assessment, (g) Online/Distance Learning, and (h) County Office of Education Workshops as being either somewhat ineffective or least effective. All of these activities are not subject specific and probably have little to do directly with the subject of music. These choices indicate that the respondents find these activities do not give them musical solutions to musical problems. One respondent wrote, "Locally sponsored in-services rarely relate to music and are a waste of time!"

6. Younger and less experienced teachers tend to participate in professional growth activities at lower levels when compared to the respondent population as a whole. In five out of the 21 activities from Table 23 where a significant difference existed, new teachers (0-5 years) participated less than the expected average. Exceptions to this trend are activities that are geared towards the new teacher such as the Beginning Teacher Support and Assessment program. Even though new teachers participate in Beginning Teacher Support and Assessment activities at rates higher than the population average, only 14 out of 38 respondents from this sub-group indicated their participation. This statistic suggests that less 
than half of new instrumental music teachers receive any benefits from this state funded program.

7. Veteran teachers with at least 15 years of experience continue to be active participants in the professional growth process even though it is not required to maintain their credential. This group of teachers is more active as leaders in music education organizations and participates in activities at rates greater than the population average.

8. A significant difference was found between two seemingly similar activities. The data indicate that the respondents overwhelmingly valued having a guest teacher or clinician rehearse their ensembles. Yet, they were not very excited about nor do they find participating in Peer Mentoring Activities to be valuable. Having a Guest Teacher or Clinician earned a mean score of 4.45 (Table 22) with a standard error of .000516 and a standard deviation of .69 and a mode of 5 , which suggests that most respondents chose this activity as being very effective. On the other hand, Peer Mentoring Activities received a mean score of 3.37 with a standard error of .12 and a standard deviation of 1.10 and a mode of 3 . This means that some teachers thought that Peer Mentoring was somewhat effective and others found it somewhat ineffective.

These findings are further supported with the data collected from section four of the survey. In this section, 162 respondents $(66.9 \%)$ indicated that Having a Guest Teacher or Clinician was one of their most valuable professional growth activities while only 21 (8.6\%) thought that Peer Mentoring was one of the top activities. Only 2 teachers felt that Having a Guest Teacher or Clinician was one of their least valuable while 12 respondents felt that Peer Mentoring activities was one of the least valuable.

9. A significant number of high school instrumental music teachers identified five professional growth activities as having little or no value for them. These activities included 
(a) Non-Music Workshops, (b) On-Campus Inservice, (c) Non-Music Conferences, (d) District Sponsored Workshops, and (e) County Office of Education Workshops. It may seem obvious that non-music activities might offer little in the way of filling the professional needs of music teachers. Yet, the data indicate the strong negative feelings these teachers have towards these activities. Each of the above activities was identified by at least $46.6 \%$ of the respondents (see Table 46) as being one of their five least valuable professional growth experiences.

10. The written responses of the survey population complemented many areas of professional growth activity. Conferences and music workshops sponsored by the music organizations were two areas that directors felt they were getting a good value especially because they had access to many different musical activities all at once. Typical comments from the teachers included: "SCSBOA can be commended for attempting to meet the needs of its members," and, "MENC and CMEA are wonderful organizations and provide service to our music education community." This satisfaction with a smorgasbord approach to professional growth is reflected in comments such as, "I appreciated the variety of choices," and, "a conference gives me a large sampling of music education trends. From a conference I can do further research in areas of importance to me."

The single overriding theme that appeared in the written comments was the opportunity to interact and network with other directors at conferences in particular and the ability to participate in group music activities in general. Many teachers expressed the sentiments of one who said, "networking with other teachers and colleagues is the best part of conferences." 


\section{Conclusions}

The following conclusions were drawn from the major findings listed in the preceding section and address the six research questions from this study.

\section{Research Question 1}

What types of professional growth activities are bigh school instrumental music teachers attending in order to satisfy the 150-hour state requirement needed to maintain the Professional Clear Single Subject Music Credertial every five years?

The respondents identified 29 different professional growth activities (Table 20) that they use to satisfy the credential requirement. These activities include the traditional such as conference attendance and workshops, to the unconventional such as research, collaborations with other agencies, and online/distance learning. A whopping $92.1 \%$ of the respondents said they attended concerts, while half or more than half participated in nine other professional growth activities. These included (a) Music Conferences (88\%), (b) Observing Other Rehearsals (78.9\%), (c) Hosting a Guest Clinician or Teacher $(71.1 \%)$, (d) On-Campus Inservice (58.3\%), (e) Music Workshops and (f) Non-Music Workshops (57.9\%), (g) New Music Reading Sessions (57.4\%), (h) Being a Guest Teacher or Clinician (57\%), and (i) Curriculum Development Meetings (51.6\%).

Even though such a large number of respondents took advantage of a variety of professional growth opportunities, the question remains why other teachers did not participate in such obviously popular professional growth activities.

While attendance at professional growth events is also universally practiced, it is apparent that teachers consider many factors when choosing which activity is viable for their participation. Two of the most important decision making factors regarding which activity to participate in are the level of experience and number of years in the current job. Teachers 
with fewer years of experience and with fewer years in their current job tend to participate in professional growth activities less than do the rest of the population (Table 23 and 24). Teachers with more years of experience and more years in their current job tend to participate more often than the rest of the population. The exception to this trend is higher participation levels in Non-Music Conferences, college coursework, and Non-Music Workshops among less experienced teachers.

\section{Research Question 2}

What professional growth activities do bigh school instrumental music teachers find effective in meeting their professional growth needs, and what activities do they find ineffective?

When combining the results of the data from sections three and four of the survey (Tables 22 and 34), high school instrumental music teachers agreed that the most effective and most valuable professional growth activities were: (a) Having a Guest Clinician or Teacher $(M=4.45 ; S D=.69)$, (b) Observing Other Rehearsals ( $M=4.29 ; S D=.71),(c)$ Attendance at Music Conferences $(M=4.02 ; S D=.89)$, and (d) Attendance at Concerts $(M=$ 4.02; $\mathrm{SD}=.76$ ) (Table 22). Thirteen respondents wrote in additional activities that they found to be most effective. These activities included performing as a musician, festival participation, conducting honor groups, clinics with university ensembles, and serving on education committees. These activities were grouped together under the category of "Other" and were rated quite high $(M=4.77 ; S D=.44)$. The Other category was identified by only six respondents as being one of their most valuable professional growth activities statistically ranked $14^{\text {th }}$ overall, when compared to other activities in section four of the survey.

Respondents identified eight categories as being either somewhat effective or average in effectiveness. These activities included attendance at Music Workshops ( $M=3.95 ; S D .80)$, 
Being a Guest Clinician or Teacher ( $M=3.82 ; S D=.95)$, taking Additional College or University Coursework ( $M=3.80 ; \mathrm{SD}=1.03)$, attending New Music Reading Sessions $(M=3.77 ; S D=.92)$, Serving in a Music Organization $(M=3.65 ; S D=1.12)$, participating in Peer Mentoring Activities ( $M=3.37 ; S D=1.10)$, engaging in Educational Research $(M=3.24$; $\mathrm{SD}=1.16)$, and Serving as a Mentor Teacher $(M=3.06 ; \mathrm{SD}=1.01)$.

On the other end of the scale, respondents identified eight categories that they found to be either somewhat ineffective or least effective. These activities included Curriculum Development Meetings ( $M=2.53 ; \mathrm{SD}=1.05)$, Beginning Teacher Support and Assessment $(M=2.42 ; S D=1.35)$, Non-Music Conferences $(M=2.33 ; S D=1.13)$, Online/Distance Learning $(M=2.16 ; S D=1.17)$, Non-Music Workshops $(M=2.14 ; S D=1.03)$, District Sponsored Workshops $(M=2.09 ; \mathrm{SD}=.96)$, County Office of Education Workshops $(M=1.95 ; S D=.98)$, and On-Campus Inservice $(M=1.91 ; S D=.89)$.

Table 56 compares mean score rankings from section three of the survey, the most effective professional growth activities with the data collected from section four of the survey and the most valuable and least valuable activities (Appendix B). The most effective activities are listed in descending order based upon the mean score. The most valuable and least valuable rankings are based upon the number of selections made by the respondents.

Table 56

Professional Growth Activity Comparison Rankings

\begin{tabular}{|c|c|c|c|c|c|c|}
\hline \multirow[b]{2}{*}{ Activity } & \multicolumn{2}{|c|}{$\begin{array}{l}\text { Most Effective } \\
\text { Rankings }\end{array}$} & \multicolumn{2}{|c|}{$\begin{array}{l}\text { Most Valuable } \\
\text { Rankings }\end{array}$} & \multicolumn{2}{|c|}{$\begin{array}{l}\text { Least Valuable } \\
\text { Rankings }\end{array}$} \\
\hline & $\mathrm{N}$ & Mean & $\mathrm{N}$ & Rank & $\mathrm{N}$ & Rank \\
\hline $\begin{array}{l}\text { 1. Having a Guest Clinician or } \\
\text { Teacher }\end{array}$ & 181 & 4.45 & 162 & 3 & 2 & 19 \\
\hline 2. Observing Other Rehearsals & 206 & 4.29 & 177 & 2 & 1 & 20 \\
\hline
\end{tabular}




\begin{tabular}{|c|c|c|c|c|c|c|}
\hline \multirow[b]{2}{*}{ Activity } & \multicolumn{2}{|c|}{$\begin{array}{l}\text { Most Effective } \\
\text { Rankings }\end{array}$} & \multicolumn{2}{|c|}{$\begin{array}{l}\text { Most Valuable } \\
\text { Rankings }\end{array}$} & \multicolumn{2}{|c|}{$\begin{array}{l}\text { Least Valuable } \\
\text { Rankings }\end{array}$} \\
\hline & $\mathbf{N}$ & Mean & $\mathrm{N}$ & Rank & $\mathrm{N}$ & Rank \\
\hline 3. Music Conferences & 215 & 4.02 & 181 & 1 & 3 & 18 \\
\hline 4. Attendance at Concerts & 228 & 4.02 & 118 & 5 & 4 & 17 \\
\hline 5. Music Workshops & 168 & 3.95 & 126 & 4 & 4 & 16 \\
\hline $\begin{array}{l}\text { 6. Being a Guest } \\
\text { Clinician/Teacher }\end{array}$ & 132 & 3.82 & 48 & 8 & 7 & 14 \\
\hline $\begin{array}{l}\text { 7. Additional College-University } \\
\text { Coursework }\end{array}$ & 138 & 3.80 & 66 & 7 & 18 & 11 \\
\hline 8. New Music Reading Sessions & 155 & 3.77 & 94 & 6 & 6 & 15 \\
\hline $\begin{array}{l}\text { 9. Service in a Music } \\
\text { Organization }\end{array}$ & 130 & 3.65 & 39 & 9 & 26 & 10 \\
\hline 10. Peer-Mentoring Activities & 83 & 3.37 & 21 & 11 & 12 & 13 \\
\hline 11. Educational Research & 78 & 3.24 & 22 & 10 & 45 & 9 \\
\hline 12. Service as a Mentor Teacher & 72 & 3.06 & 13 & 12 & 14 & 12 \\
\hline $\begin{array}{l}\text { 13. Curriculum Development } \\
\text { Meetings }\end{array}$ & 148 & 2.53 & 13 & 13 & 71 & 6 \\
\hline $\begin{array}{l}\text { 14. Beginning Teacher Support \& } \\
\text { Assessment }\end{array}$ & 48 & 2.42 & 6 & 15 & 46 & 8 \\
\hline 15. Non-Music Conferences & 135 & 2.33 & 3 & 18 & 119 & 3 \\
\hline 16. Online/Distance Learning & 51 & 2.16 & 4 & 17 & 60 & 7 \\
\hline 17. Non-Music Workshops & 134 & 2.14 & 2 & 21 & 139 & 1 \\
\hline 18. District Sponsored Workshops & 137 & 2.09 & 5 & 16 & 117 & 4 \\
\hline $\begin{array}{l}\text { 19. County Office of Ed. } \\
\text { Workshops }\end{array}$ & 58 & 1.95 & 2 & 19 & 113 & 5 \\
\hline 20. On-Campus Inservice & 173 & 1.91 & 2 & 20 & 123 & 2 \\
\hline 21. Other & 13 & 4.77 & 6 & 14 & 0 & 0 \\
\hline
\end{tabular}


The $\mathrm{N}$ in each category refers to the number of times an activity was cited by the respondents. The lower the number in the most valuable ranking column, the higher the ranking. This means a low number in Most Valuable Rankings is good while a low number in Least Valuable Rankings is not good. These data reinforce the connection between each of the three survey sections and strengthens the validity of the study.

Therefore, it would follow that activities, which directors found to be most valuable, had few selections as a least valuable activity and thus garnered higher mean score averages. The inverse is also true. Activities that were found to be least valuable garnered low mean score averages and had few selections as a most valuable activity. For example, the top five most effective activities and the top five most valuable activities ranked in the bottom five of the least valuable activities. While 168 or more respondents chose the top five most effective activities only four or less choose those same activities as least valuable.

At the other end of the spectrum, the five least effective activities were chosen by 51173 respondents. That is, Non-Music Workshops, Non-Music Conferences, District Sponsored Workshops, County Office of Education Workshops, and On-Campus Inservice were the least valuable and also the least effective. No more than five respondents chose these activities as most valuable.

\section{$\underline{\text { Research Question } 3}$}

To what extent do high school instrumental music teachers participate in non-traditional professionalgrowth activates such as peer mentoring and music education research?

The data indicate that very few high school music teachers participate in professional growth activities that are sole pursuits. These activities include Online/Distance Learning and Educational Research. Band directors tend to gravitate towards sponsoring large group musical activities. Forty-five respondents $(18.6 \%)$ indicated that they had engaged in 
Educational Research during the past three years, while only nineteen $(7.9 \%)$ had used Online/Distance Learning as a professional growth activity.

Group activities are favored because of the ability to network and meet with other directors and share ideas. Many directors wrote that, "Music conferences provide opportunities for networking to set up solo/ensemble festivals, exchange concerts (shared concerts), visitations, and observations etc." Group activities also provide opportunities for observation of master teachers and honor group conductors.

In written statements (Appendix E) provided by the respondents, comments indicate that the words network, share, exchange, meet, watch, connect, or observe were mentioned 88 times within the 227 comments. The word other(s) was mentioned 76 times, further reinforcing the value of interaction and collaborative opportunities provided by group activities.

\section{Research Question 4}

Is there a difference in professional growth activities and needs among bigh school instrumental music teachers who work in urban, rural, and suburban areas of the state?

There is generally no difference in participation levels among teachers from different school locations. There are two exceptions to the overall data. The exceptions are participation levels in District Sponsored Workshops and the category Other, which includes additional activities listed by the respondents themselves such as performing as a musician, festival participation, conducting honor groups, clinics with university ensembles, and serving on education committees.

High school instrumental music teachers in rural schools attended District Sponsored Workshops $17.7 \%$ less than the expected average while teachers from suburban and urban schools participated more than the expected average. 
These data suggest that teachers in rural school locations tend to "create" and utilize different types of professional growth activities such as performing as a musician while shying away from traveling to district sponsored events. This Other activity category seems to be chosen more by rural teachers because such activities meet the needs of both the teacher and the California Commission on Teaching Credentialing.

While there is greater participation in Other activities among rural teachers, there is less participation in activities that would apparently meet these teachers' needs such as online/distance learning. Yet, with such few teachers from all categories participating in either online/distance learning or other kinds of activities the question becomes why isn't there a higher participation level in these activities? This is especially evident with all of the money being allocated towards improving technology in the schools. The answer lies in the fact that these activities are solitary pursuits while activities with higher participation levels and higher satisfaction levels (such as Music Conferences and Hosting a Guest Clinician or Teacher) are activities that allow sharing and interaction with immediate feedback. One respondent commented about online/distance learning as a most valuable activity wrote, "Living in rural areas makes opportunities for completing state requirements for preliminary credential holders difficult. Online/distance learning opportunities offer a possible solution." This is not exactly a ringing endorsement for these activities.

\section{$\underline{\text { Research Question } 5}$}

What are the implication of this study for the state music organizations such as the Soutbern California School Band and Orchestra Association (SCSBOA), the California Band Directors Association (CBDA), and the California Music Educators Association (CMEA)? 
The data suggest that music organizations that provide professional growth opportunities for high school instrumental music teachers would be advised to consider three areas that impact the participation levels and perceptions of value of the constituents.

The first area of concern is one of cost. Respondents indicated that $32.2 \%$ received no financial support from their school districts for professional growth expenses. The data indicate (Table 27) that professional growth activities that traditionally cost money to participate in had lower participation levels when these teachers received no reimbursement from their districts. These activities were music conferences and music workshops. On the other hand, participation rates for County Office of Education workshops, which traditionally do not charge for participation, were higher than the population average. Unfortunately, County Office of Education workshops are viewed as one of the least effective professional growth activities by the survey respondents.

Only $9.5 \%$ of respondents were reimbursed for all professional growth expenses. While a significant majority $(64.4 \%)$ did receive some reimbursement, some directors felt that the costs associated with attending conferences need to be curtailed. As one director wrote that conferences were "too expensive, especially MENC."

The second area of concern involves meeting the specific needs of the various levels of teacher experience. Newer teachers want activities geared towards their specific needs. Many of the respondents who indicated that they had been teaching less than five years were not participating in other new teacher programs such as Beginning Teacher Support and Assessment (Table 23). On the other hand, experienced teachers feel their needs are not being met because many conference offerings are directed towards perceived needs of new teachers. There were many comments (Appendix F) that expressed both sides of this issue. For example, some respondents wrote, "How about seminars for new music teachers? The 
duties are enormous and we need ideas for discipline, fund-raising, accounting, etc."; "There must be much more support for new teachers. They are floundering!"

Conversely, one experienced teacher wrote, "Those of us that have been in the profession for years are not interested in clinics for young, inexperienced directors. Gear something for us." While it may not be practical to offer sessions for all experience levels, music organization could indicate (through appropriate methods) which sessions are suitable for various levels of teaching experiences.

The third area of interest indicated by the respondents and having an implication for the music organizations is in the area of attendance and participation. While the respondents indicated high levels of both satisfaction and attendance in the professional growth activities sponsored by the music organizations, segments of the population remain that do not attend music-specific professional growth activities.

Not one single respondent indicated they had not attended any professional growth activities during the previous three years. Yet, many are not taking advantage of the most popular activities, which include conferences and workshops hosted by professional music organizations. The respondents indicated that $7.9 \%$ did not attend concerts (Table 23), 12\% did not go to a music conference, $21.1 \%$ did not observe a rehearsal, $29 \%$ did not host a clinician, and a large group (42.2\%) did not attend a music workshop. As one instrumental teacher wrote, "Work hard to get every member to attend! Do better than the 80/20 rule possible ( 80 percent of the work done by only 20 percent of the organization)."

Because so many high school instrumental music teachers are relying on professional music education organizations for professional growth opportunities, it is incumbent on these organizations to find ways to include all of the appropriate music education community and not just those who are members of that particular organization. 


\section{Research Question 6}

What are the implications for school district leaders such as princip als, district administrators, and curriculum coordinators with regard to providing staff development for the high school instrumental music teachers?

With $35.1 \%$ of the respondents indicating that they have a music supervisor (Tables 10 and 11 ) and with only $41.1 \%$ of those indicating their supervisor provided professional growth activities, it is evident that many teachers are left to their own devices in searching out appropriate professional growth activities. This suggests that, by default, the responsibility for providing professional growth activities appears to have been placed squarely in the hands of the music organizations.

Because these teachers cannot find appropriate professional growth activities through their districts and schools, it is extremely important that these districts provide the resources necessary in order that affected teachers are supported in the same manner as the rest of the teacher population. Setting aside enough money in the budget to allow instrumental music teachers to attend activities that directly relate to their professional growth would greatly improve this situation.

Additional data gathered from the results of section three of the survey indicate that the lowest rated professional growth activities were activities sponsored by the county education offices and school districts. When asked to rate the effectiveness of a variety of professional growth activities, the three lowest mean average scores were those activities that district and county education administrators control. These were On-Campus Inservice $(M=1.91 ; S D=.89)$, County Office of Education Workshops $(M=1.95 ; S D=.98)$, and District Sponsored Workshops $(M=2.09 ; \mathrm{SD}=.96)$. The high school music teachers felt that these 
activities are ineffective because administrators "do not usually have a concept of what we do," and "locally sponsored in-services rarely relate to music and are a waste of time!"

Another area where school districts need improvement is in programs that impact new teachers. Education districts need to enhance programs such as Beginning Teacher Support and Assessment and other new teacher programs when it comes to dealing with arts educators in general and high school instrumental music teachers in particular. Support for new teachers is even more critical considering the current shortage of teachers in the state and the eagerly anticipated resurgence of music programs in districts throughout the state.

\section{Implications and Recommendations}

\section{Implications}

The results of this study have implications for high school instrumental music teachers that hold credentials in California, school district administrators, colleges and universities that offer professional growth coursework, and professional music organizations that provide professional growth opportunities. The macro view paints a picture of two different entities working in moderate harmony but sometimes in discord with each other. On one hand is the high school instrumental teacher who relies primarily on his or her own efforts, resources and imagination in searching out appropriate activities that will satisfy state requirements. On the other hand are all the other institutions, and professional music education organizations involved in providing and requiring growth activities: the school administrators, district administrators, professional education organizations, and the state.

To some extent, there is a positive relationship between teachers and the music education organizations. Professional music organization that are currently providing professional growth opportunities for California's public high school instrumental music teachers need to continue to offer such opportunities for these teachers. While there is a 
little discontent among these organizations' members with some of the offerings, the vast majority are pleased with the types of offerings.

However, the relationship between the expectations of these teachers and the opportunities provided by school and district personnel is quite negative. With such highprofile organizations on their campuses such as the high school band and orchestra, school administrators should be looking for more ways to enhance the teaching capabilities and performance capabilities of their staff by encouraging them to look beyond the immediate school and district for professional growth opportunities. A teacher who is forced to participate in a professional growth activity unrelated to their subject area is an unhappy teacher. According to the data (Table 23), more than half of the respondents are attending On-Campus Inservice, Non-Music Workshops, and Curriculum Meetings and these respondents are indicating that these are the least effective and the least valuable activities. There appear to be a number of unhappy music teachers.

\section{$\underline{\text { Recommendations }}$}

High school instrumental music teachers need to explore all areas of professional growth opportunities that are outlined in the professional growth manual. While attendance conferences and participation in some of the more popular activities appears to be satisfying the immediate needs for professional growth requirements, there are many other activities that could be utilized. One of these options includes continuing to perform on their instrument in some creative capacity. Teachers should look for high quality performance experiences where challenging and quality musical literature is performed. Teachers also should invite local professional musicians to their campus and have these experts run sectionals, solo for the band and orchestra, and/or present some type of clinicwhere both the students and the teacher could benefit. 
Organizations that provide professional growth activities on a short-term basis could identify and publish a list of mentors available for use by teachers who work in isolated areas. There seems to be a need for these secluded schools to have access to visiting clinicians. Good sources of mentor teachers are those music educators who have retired, and who are willing to provide occasional help, especially for new teachers. Professional music organizations could explore resources and funding for retired teachers to travel to remote music programs and provide clinics for these schools and teachers.

Professional music organizations could create and publish a list of master teachers and outstanding programs that would be available for visitation and consultation by other teachers. Likewise, these organizations could also create a list of professional musicians who would provide clinics, demonstrations, and lessons for the teachers and their students. Districts and individual schools could set aside specific funds to support such activities.

Professional organizations should develop a "participation certificate" that would be accepted by the Commission on Teacher Credentialing for the 150 hour requirement and offer opportunities for continuing education credit through a local university.

Organizations that host conferences should identify which of their seminars, clinics, or workshops are appropriate for new teachers and which are appropriate for experienced teachers.

Teachers who are currently participating in the BTSA program should include in their Individual Induction Plan (IIP) content specific goals and directed interactions with qualified music educators because generic teacher assistance only goes so far. The IIP should also include travel to music conferences and visitations to observe quality music programs. Finally, the IIP should include visitations and clinics at the teacher's school by qualified clinicians. All of the costs associated with these recommendations are funded through the 
BTSA program. The amounts are determined by the type of credential the BTSA participant holds and varies between $\$ 2,000$ and $\$ 5,150$ per academic year per person. While these amounts vary, this is enough to also provide release time for the BTSA participant to travel and visit other music programs.

If a qualified music educator is not available to serve as a BTSA mentor, then the participant should consider locating and asking a retired music educator for help.

Those new music educators who are not participating in BTSA and who qualify should meet with their administrator and request admittance into the BTSA program and access to funds in order to take advantage of the opportunities afforded all new teachers.

Funding and resources should be made available to all teachers regardless of location, teaching experience, and program size. Districts and the state officials need to provide for professional growth activities as part of the overall district and state budget - especially since the passage of SB 813 . Because music teachers are finding their professional needs met outside the district, reimbursement of expenses needs to be made available to every teacher. It is incumbent upon the individual teacher to make requests from the site administrator for reimbursement of professional growth expenses and not wait for the administrator make an offer. It is also incumbent upon the teacher to justify participation in appropriate off-campus activities in order to maintain a high level of trust between the administration and themselves.

All of us involved in the high school instrumental music education community need to balance the competitive nature of the job with aspects of the mentoring process. Offering true collaboration and being willing to share ideas and solutions with others will create a positive atmosphere for music education. This atmosphere is crucial to the future of our high school music programs especially since 1992 when the Consortium of National Arts 
Education Associations created the National Standards for arts education. It is essential for high school instrumental music teachers to see beyond only the performance aspects of their profession and begin incorporating other standards in their rehearsal room. While it is admirable that these teachers strive for excellence in performance, it is only a portion of the musical arts that are being taught. High school instrumental music teachers need to incorporate additional standards into their lessons. Some of these Standards include the ability to create and improvise music; the ability to understand and evaluate music; the ability to understand the relationship between music and the other arts; the ability to understand the relationship between music and disciplines outside the arts; and the ability to understand the relationship between music and history and culture. These demands will necessitate an even greater amount of collaboration between teachers, administrators and music education organizations resulting in a more balanced and educationally sound music program.

Finally, something needs to be done to combine the most effective elements of the traditional professional growth practices such as interactions and sharing with fellow professionals and the best of technological innovations, which include immediacy and the ability to transcend distances. For example, a library of topics, which have been presented at all of the conferences, could be videotaped and converted into accessible data that can be retrieved over the World Wide Web. Alternatively, the creation of an email based discussion group or chat room where directors could post questions or respond with constructive suggestions. This list serve management could be administrated by the music education organizations and be made available to all music educators -- even those who were not members.

Another idea would be for the music education organizations to offer web-based clinic presentations. This type of presentation would allow any clinician in the world to broadcast 
and to have it viewed by any director connected to the web. Directors who were viewing the presentation live could send questions and comments in the form of an instant message to the clinician. This clinic could also be recorded for later release.

Technology exists to allow a director to set up a camera that would transmit live pictures and sound of his group and have them viewed by a clinician anywhere in the world without incurring the expense of time and money to have that clinician visit the school site. While the musical sound quality may not yet be very good, the opportunity to have another set of eyes and ears watch what is happening in the rehearsal is invaluable.

While technology has the ability to leap across distances and involve music teachers regardless of where they live, to be truly useful, it must incorporate elements of professional growth suggested by this study's population. Moreover, while traditional professional growth activities remain popular with high school instrumental music teachers music education organizations must find ways to involve every music teacher. Because school districts are budgeting lots of money for digital technology, music organizations and school districts should review technology as another tool to make these connections with all music teachers.

\section{$\underline{\text { Recommendations for Future Study }}$}

There is also a need for replicating this study on a national level to embrace all areas of public school music education including choral and general music in grades $\mathrm{K}-12$. This depth of research would provide music inservice providers with a comprehensive understanding of the professional needs of all music educators.

Much like our national census, this study should be repeated every five to ten years in order to determine changes in professional growth habits, demographics, and trends. A continuing assessment and re-evaluation of teacher's needs could contribute to the effectiveness of professional growth offerings. 
A study to examine the correlation between the types of professional growth activities attended and the national Standards would provide an insight as to whether the Standards are being incorporated into the curriculum and whether or not professional growth activities are meeting the needs of the teachers to implement the Standards in the high school instrumental classroom.

A study that delves into the specific types of activities high school music teachers attend rather then the general types would further reveal the professional growth habits of this population. For example, do these teachers attend sessions on assessment or standards implementation as part of their conference attendance?

While documenting the professional growth habits of music educators provides one view of the professional growth experience, a study that looks into the long-term effect of these activities would provide another interesting perspective.

\section{Closing Comments}

This study depended upon the experiences and feedback from over 250 high school instrumental music educators. These teachers have provided a wealth of data that districts and music organizations should consider when shaping their professional growth activities. Taking into account the data presented in this study will result in developing and retaining competent and quality music educators. The consequence of creating a professional growth team involving teachers, music education organizations, and school districts will be stronger and more viable music programs. On the other hand, teachers should be taking advantage of all district resources available for professional growth activities. Teachers, districts, and music education organizations all have a stake in the success of each other. To paraphrase Peter Senge from his book The Fifth Discipline: The Art and Practice of the Learning Organization (1990), how can groups of educators committed to the success of teaching be made up of highly 
intelligent individuals with IQ's above 120 but when working together as professional growth partners have a collective IQ of 63 ?

The answer to this question lies in the ability of each group to develop channels of communication that provide continuous opportunities for dialog and a willingness to share good will, resources, and expertise. When there is a genuine commitment to advance the professional growth needs of high school instrumental music educators among all parties involved in the professional growth process, then meaningful change will occur - change that will foster the artistic and professional growth of all who work for the ultimate educational benefit of the students. 


\section{REFERENCES}

Adderley, Cecil L. III. (1996). Music teacher preparation in South Carolina colleges and universities relative to the national standards: Goals 2000. (Doctoral dissertation, University of South Carolina, 1996). OCLC, AAG 9711655

Alreck, P. L., Settle, R. B. (1995). The survey research handbook: Guidelines and strategies for conducting a survey. New York: Irwin Professional Publishing.

Bell, John R. (1986). The high school band: Instructional tasks, administrative tasks, and terminal outcomes. University of Illinois at Urbana-Champaign,

Bolam, R. (1980). In-service education and training. In E. Holye \& J. Megarry (Eds.), World Yearbook of Education, 1980: Professional development of teachers. (pp. 85-97). London: Kogan Page \& New York: Nichols Publishing Co.

Brown, Patricia A. (1987). An investigation of problems which cause stress among music teachers in Tennessee. (Doctoral dissertation, University of Tennessee, 1987). OCLC, AAG8713451.

California Dept of Education. (1999). The California professional growth manual for multiple and single subject credentials and services and specialist credentials. Sacramento: California Commission on Teacher Credentialing.

California Education Code $₫ 44251$

California Education Code. $\$ 44277-2 b$ 
Creswell, John W. (1994). Research design: Qualitative \& quantitative approaches. Thousand Oaks, CA. Sage Publications, Inc.

Gregory, Michael D. (1986). A descriptive analysis of factors which contribute to job dissatisfaction among secondary school band directors. (Doctoral dissertation, Auburn University, 1986). OCLC, AAG 8624454.

Hayes, Karen L. (1996). The cadre project: Collaboration for development of new and veteran teachers. A multiple case study. (Doctoral dissertation, University of Nebraska, 1996). OCLC, AAG9715965.

Heifetz, R. (1994). Leadership without easy answers. Cambridge, MA: Belknap Press

Herdt, T. (1998, November 18). Survey: Improving teacher quality a priority. North County Times, p. A5.

Joyce, B. (1980). The ecology of professional development. In E. Holye \& J. Megarry (Eds.), World Yearbook of Education, 1980: Professional development of teachers. (pp. 1941). London: Kogan Page \& New York: Nichols Publishing Co.

Kennedy, Janet E. (1996). Professional growth decisions of mid-career teachers and influencing work context factors. (Doctoral dissertation, Temple University, 1996). OCLC, AAT 9632054.

Marczely, B. (1996). Personalizing professional growth: Staff development that works. Thousand Oaks, CA: Corwin Press.

Marks, Laurence L. (1994). The effectiveness of music teacher pre-service training in california's colleges and universities: Professional preparation and teacher retention. (Doctoral dissertation, University of Southern California, 1994). OCLC AAI 9601026 
Nardo, Rachel L. (1996). California survey of music in early childhood: teacher preparation and the role of the community college. (Doctoral dissertation, University of Southern California, 1996). OCLC, AAG9720270.

Niday, Donna Mae. (1996). Beginning again: Mentoring the novice teacher. (Doctoral dissertation, University of Iowa, 1996). OCLC, AAG9640008.

Nimmo, Douglas J. (1986). Factors of attrition among high school band directors. (Doctoral dissertation, 1986). OCLC, AAG8701356.

Oja, S. N. (1989). Teachers: Ages and stages of adult development. In M. L. Holly \& C. S. McLoughlin (Eds.), Perspectives on teacher professional development. (pp. 119-154). London: Falmer Press.

Okun, Mathew J. (1998). Multicultural perspectives in undergraduate music teacher education programs. (Doctoral dissertation, University of New Mexico, 1998). OCLC, AAG9826648.

Rea, L. M., \& Parker, R. A. (1992). Designing and conducting survey research: A comprehensive guide. San Francisco: Jossey-Bass.

Reimer, Bennett. (1989). A philosophy of music education ( $2^{\text {nd }}$ ed.). New Jersey: Prentiss-Hall.

Sapp, Terry Myles. (1996). Teacher perceptions of the components of effective inservice training in the fine arts and their relationship to the implementation of curriculum. (Doctoral dissertation, Georgia State University, 1996). OCLC, AAG9628841.

Schafer, Carl William. (1977). The development of a model professional preparation program for prospective music teachers in California. (Doctoral dissertation; University of Southern California, 1977). OCLC, AAG7302601.

Smith, Jeanne S. (1998). Qualitative focus group study of crystallizing and flow 
experiences in educators' professional development. (Doctoral dissertation, Indiana University of Pennsylvania, 1998). OCLC, AAG9825582.

Smith, Michael V. (1994). The mentoring and professional development of new music educators: A descriptive study of a pilot program. (Doctoral dissertation, University of Minnesota, 1994).

Tauer, Susan M. (1995). The mentor-protégé relationship and its impact on the experienced teacher. (Doctoral dissertation, Boston University, 1995). OCLC, AAI9514987.

Temple, Richard B. (1972). An environmental study utilizing the inquiry process in preparing preservice instrumental music educators. (Doctoral dissertation, Arizona State University, 1972). OCLC, AAG7230139.

Vardi, Dina. (1992). Transformational mentorship: Parallel processes in teacher development. (Doctoral dissertation, Cleveland State University, 1992). OCLC, AAG9237172.

Wade, Margaret W. (1993). The voices of mentor teachers: Reflections on the mentoring experience. (Doctoral dissertation, Peabody College for Teachers of Vanderbilt University, 1993). OCLC, AAG9324259.

Wang, Lin. (1996). A typology and evaluation of the survey sample designs in the Educational Administration Quarterly: 1980-1995. (Doctoral Dissertation. Texas A \& M University, 1996)..

Wohl, Mark A. (1993). The small town band director: A descriptive case study. (Doctoral dissertation, University of Oregon, 1993). OCLC, AAG9405240. 
APPENDICES

APPENDIX A.

APPENDIX B.

APPENDIX C.

APPENDIX D.

APPENDIX E.

APPENDIX. F
CONSENT FORM

THE SURVEY INSTRUMENT

POSTCARD REMINDER

EMAIL MESSAGE

WHY RESPONDENTS CHOSE THEIR NUMBER ONE

ACTIVITY

COMMENTS TO ORGANIZATIONS 
APPENDIX A:

CONSENT FORM 
March 5, 2000

\section{Dear Fellow Music Educator:}

I am a doctoral student at the University of San Diego conducting research on professional growth for high school instrumental music teachers. In music education, we are constantly seeking ways to improve our skills and our teaching effe ctiveness. One suggested method is to analyze the number and types of professional growth activities we attend.

The purpose of this survey is to solicit your help in identifying the different professional growth activities you have attended since Septembe $r$ 1996. In addition, this survey asks for your opinion as to how much these activities have helped you in your teaching. Finally, this survey seeks to identify activities that you find most valuable and least valuable.

This research study is for anybody who teaches high school instrumental music; so if you do not teach high school instrumental music would you please give this survey to that teacher on your campus. This survey should take about 30 minutes to complete.

By voluntarily completing the enclosed survey and returning it to me, you understand that:

- there is no personal risk or expense involved.

- this project will provide information about professional growth needs, perceptions, and opportunities for high school instrumental music teachers.

- you can ask questions about the project and receive answers.

- all data will be reported in such a way to protect anonymity.

- There is no agreement, written or verbal, beyond that expressed in this consent form.

- you consent to voluntary participation in this project, and can withdraw at any time with no adverse consequences.

By completing and returning the survey I, the undersigned, understand and accept the above explanations and on that basis, I give consent to my voluntary participation in this research.

your signature

school zip code

dare

I would be most appreciative if you took about 30 minutes of your time to complete this survey and return this letter and survey in the included stamped envelope. This consent form will be removed prior to the analysis of any data. Your cooperation is greatly appreciated.

Musically yours,

Charles Friedrichs, Lecturer

School of Music and Dance, San Diego Stare University

5500 Campanile Dr., San Diego, CA 92182, e mail: cfriedr1@san.rr.com

Telephone: (619) 594-1600 wk, (858) $592-7870 \mathrm{hm}$

If you would like a copy of the survey results, please put your email address in the following space and I will send you results as soon as they are compiled. Thank you.

Email address: 
APPENDIX B:

\section{SURVEY INSTRUMENT}

Reproduced with permission of the copyright owner. Further reproduction prohibited without permission. 
Section I: Please tell us a little about yourself and your job.

1. How long have you been a high school instrumental music teacher?

$\begin{array}{ll}\square & 0 \text { to } 2 \text { years } \\ \square & 3 \text { to } 5 \text { years } \\ \square & 6 \text { to } 10 \text { years } \\ \square & 11 \text { to } 14 \text { years } \\ \square & 15 \text { or more years }\end{array}$

2. How long have you been in your current job?

$\begin{array}{ll}\square & 0 \text { to } 2 \text { years } \\ \square & 3 \text { to } 5 \text { years } \\ \square & 6 \text { to } 10 \text { years } \\ \square & 11 \text { to } 14 \text { years } \\ \square & 15 \text { or more years }\end{array}$

3. What credential do you currently hold?

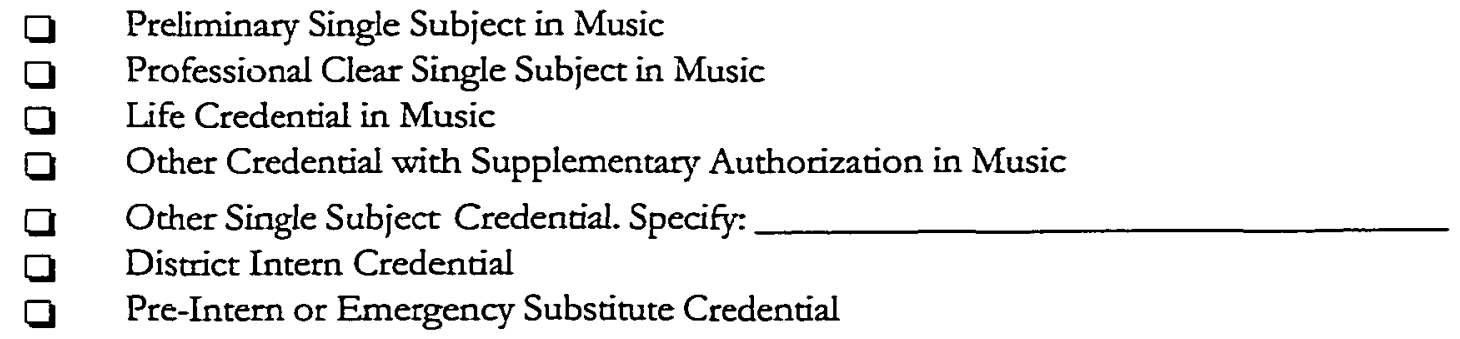

4. What is your professional education background. Check all that apply.

$\begin{array}{lll}\square & \text { Bachelors in Music or Music Education } & \square \text { Other Bachelors } \\ \square \text { Masters in Music or Music Education } & \square \text { Other Masters } \\ \square \text { Doctorate in Music or Music Education } & \square \text { Other Doctorate }\end{array}$

5. How much does your district reimburse you for professional growth expenses such as travel, conference fees, and/or tuition?

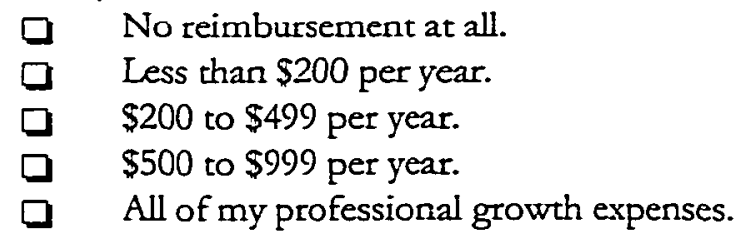

6. Which best identifies the location of your high school?

$\begin{array}{ll}\square & \text { Rural } \\ \square & \text { Suburban } \\ \square & \text { Urban and/or Inner City }\end{array}$

7. How many music teachers teach at your school, including yourself?

$\begin{array}{llll}\square & \text { One } & \square & \text { Three } \\ \square & \text { Two } & \square & \text { Four or more }\end{array}$


8. How many high school instrumental music teachers teach in your district, including yourself?

$\begin{array}{ll}\square & 1 \\ \square & 2 \text { to } 4 \\ \square & 5 \text { to } 9 \\ \square & 10 \text { to } 19 \\ \square & 20 \text { or more } \\ \square & \text { Unknown }\end{array}$

9. Does your district have a music coordinator or supervisor?

$$
\begin{array}{ll}
\square & \text { YES } \\
\square & \text { NO }
\end{array}
$$

10. If YES, does he/she provide professional growth activities?

$$
\begin{array}{ll}
\square & \text { YES } \\
\square & \text { NO }
\end{array}
$$

11. If NO, Do you or another teacher have music supervisor duties as part of your teaching assignment?

$$
\begin{array}{ll}
\square & \text { YES } \\
\square & \text { NO }
\end{array}
$$

12. What is your school size?

$\begin{array}{ll}\square & \text { Fewer than } 499 \text { students } \\ \square & 500 \text { to } 999 \\ \square & 1,000 \text { to } 1499 \\ \square & 1,500 \text { to } 1999 \\ \square & 2000 \text { to } 2499 \\ \square & 2500 \text { or more }\end{array}$

13. How many total students at your school participate in instrumental music (including auxiliary corps, flags, drill team, etc), band, orchestra, and/or jazz ensemble?

$\begin{array}{ll}\square & \text { Fewer than } 75 \\ \square & 76 \text { to } 124 \\ \square & 125 \text { to } 174 \\ \square & 175 \text { to } 224 \\ \square & 225 \text { or more }\end{array}$

14. To which of the following music education organizations do you belong? Please check all that apply.

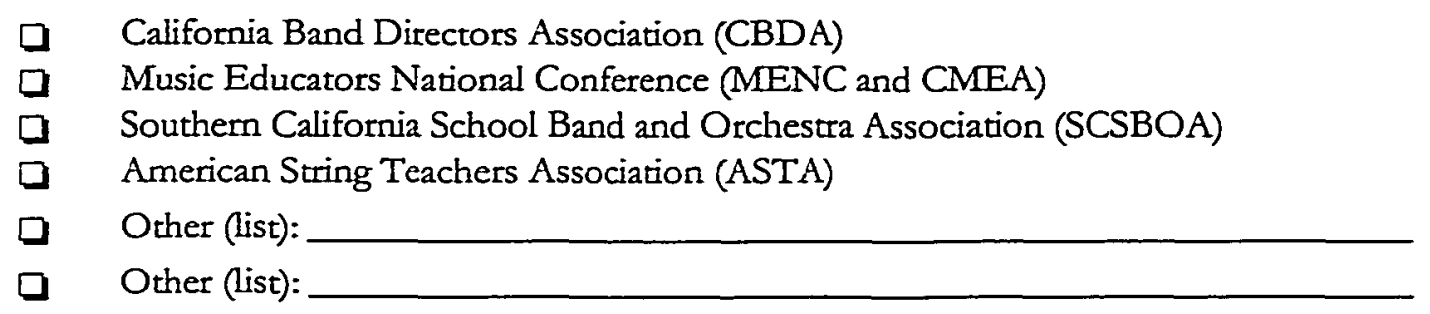


15. Please list any other professional organizations to which you belong.
A
B
C
$\mathrm{D}$

16. Have you participated in any school/university collaborative programs for music teachers?
a NO
a TCAP (The California Arts Project)
口 IMPACT (Instrumental Music Programs: Academy for/by County Teachers)
- Other - specify:

17. Are you:
口 Male
Caucasian
a Female
口 Non-Caucasian

Please provide your opinions to the following questions. Check the boxes that best describue your answer. Your responses will be kept confidential.

Section Il: During the past three years, which of the following professional growth activities did you attend. Check all that apply.

$\square$ Music Conferences

$\square$ New music reading session $\square$ Curriculum development meetings

$\square$ Additional college/univ. courses

$\square$ Guest teaching/clinics

Non-music workshops/inservice

$\square$ Online/Distance learning
Music Workshops

$\square$ Service as a mentor teacher

$\square$ Non-music conferences

Serve in a professional music org.

Having a guest clinician

District sponsored workshops

BTSA related activity $\square$ On-campus In-service

$\square$ Peer mentoring activities

$\square$ Observing other rehearsals

$\square$ Educational research

$\square$ Attendance at concerts

$\square$ County Office of Ed. workshops

$\square$ None

$\square$ Other (please list)

Which one benefited you the most?

If you checked NONE, please briefly explain why. 
Section III: Of the professional growth activities that you have attended in the past three years, please rate the effectiveness of the activity in terms of how much it helped you in your professional growth needs. Rate the activity from:
(1) Least Effective
(2) Somewhat Ineffective
(3) Average in Effectiveness
(4) Somewhat Effective
(5) Most Effective.

Least Effective $\leftarrow \quad \rightarrow$ Most Effective
1. Music Conferences
(1)
(2)
(3)
(4) (5)

2 Musicworkshops

(2) $=(3)+14$ (4)

\section{On-campus in-service}

(1)

(2)

(3)

(4)

(5)

4 13 New musicirading sessions

(4) 6 (5)

5. Service as a mentor teacher

(1) (2)

(2) (3)

(4)

(5)

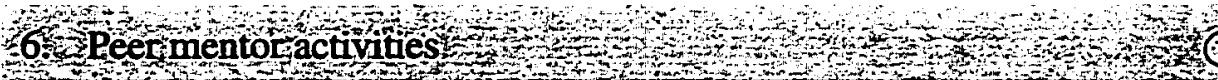

(1) $12+2$

7. Curriculum development meetings

(1)

(2) (3) (4)

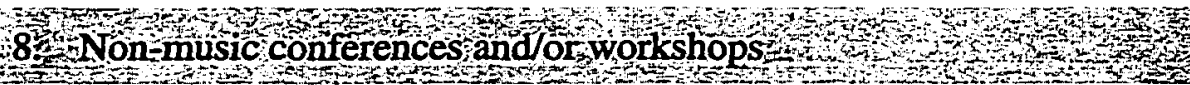

\section{Observing other rehearsals}

(1)

(2)

(4) (5)

10. Eollege/university coursework workshops o seninars

(1) (2)

(2) (3)

(4) $5(5)$
11. Service in a professional music organization
(1)
(2)
(3)
(4)
(5)

(1)

(2) 3

(4)

(5)

12 Educationaliresearch

13. Being a guest teacher and/or clinician

$1+2+4$

(2) $3+2$

(3) 3 (4) (4)

14 Having guest teacher and or clinician a your school

(1)

(2)

(3)

(4) (5)

15. Attendance at concerts

15. Attendance atconcerts

(1)

(2)

(3)

(4)

(5) 16 Non musicworshops inserve

(1) 12

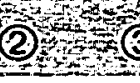

\section{District sponsored workshops}

(1)

(2)

(3)

(4) 18 eonnt office of Education workshops

19. Online/Distance learning (1)

12

2)

(1)

(2)

(3)

(4)

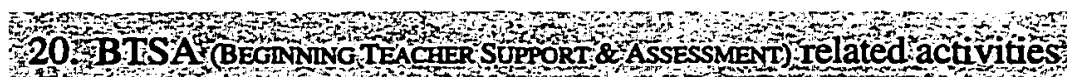

21. Other:

(1)

(2)

(3)

(4)

(5) 
Section IV: Rank the following. In the following chart, please list the numbers of the top 3-5 activities that you would find most professionally valuable as a high school instrumental music teacher and the numbers of the 3-5 least valuable activities.

1. Attendance at music conferences.

3. Attendance at music workshops.

5. On-campus inservice.

7. New music reading sessions.

9. Service as a mentor teacher.

11. Participating in peer mentoring activities.

13. Curriculum development meetings.

15. Non-music conferences

17. Observing other rehearsals.

19. Taking additional university or college coursework.

21. Other, (please list)

\section{MOST VALUABLE}

1.

2.

3.

4.

5.

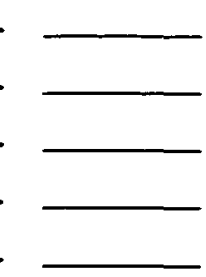

2. Conducting educational research.

4. Being a guest teacher and/or clinician.

6. Having a guest clinician/teacher work with your group.

8. Attendance at concerts

10. Non-music workshops or inservice.

12. District sponsored workshops

14. County Office of Ed. Workshops

16. Online/Distance learning

18. BTSA related activities

20. Serving in professional music organizations
LEAST VALUABLE

1.

2.

3.

4.

5.

Please write a brief statement about why you chose your number 1 rated professional growth activity as your most valuable.

Do you have additional comments for organizations that provide professional growth activities for high school instrumental music teachers? 
APPENDIX C:

POSTCARD REMINDER 
Dear Instrumental Director:

Recently you received a survey asking your opinion about professional growth as a music educator. If you have already completed the survey, I want to thank you for your time and effort. If you have not completed the survey yet, would you please take 20 minutes of your time to do so and return it in the postage paid reply envelope.

I would be happy to send another copy to you if you cannot find the original. Please email me at cfriedr1@.san.rr.com with your school name and address and I will send you one ASAP.

Thanks again. Your opinions are important to the success of this research.

Charles Friedrichs, researcher

Lecturer in Music

San Diego State University 
APPENDIX D:

EMAIL MESSAGE 


\section{Dear Instrumental Music Teacher:}

I hope this message finds you in a satisfied mood as you wind down a successful school year. I am writing to you because I need your help. Recently you received a survey asking your opinions about professional growth as a music educator. If you have already completed the survey in want to thank you for your time and effort. If you have not completed the survey would you please find it and take about 20 minutes to complete it, sign the consent form, and send the entire package back to me in the postage paid reply envelope.

I would be happy to send another copy to you if you cannot find the original or you never received one in the first place. Just respond to this email with your name and mailing address and I will send you one ASAP.

Your opinions are important to the success of this research, as it will benefit our music education organizations. Should you have additional questions I would be happy to answer them. My phone number is in the SCSBOA directory or you can email me at cfriedr1@san.rr.com.

Have a restful summer and thanks again for your time.

Respectfully,

Charles Friedrichs, researcher

Lecturer in Music

San Diego State University 
APPENDIX E:

WHY YOU CHOSE YOUR NUMBER ONE PROFESSIONAL GROTTH ACTIVTTY 


\section{Please write a brief statement about why you chose your number 1 rated professional growth activity as your most valuable.}

1. Watching other conductors work gives you good insights and suggestions to various teaching strategies.

2. Music specific workshops are obviously more likely to improve your music teaching than nonmusical ones.

3. (Peer mentoring). I learned so much working closely with others in my group. I got to know so many more band directors and had more opportunities to learn from others and discover opportunities for my program and my students.

4. Sharing techniques and strategies with peers, interaction with other music educators, access to members and latest merchandise and technology.

5. Conferences have given me the greatest variety of experiences from those listed.

6. Net working with other teachers and sharing ideas, seeing the latest research developments.

7. It is important to learn from the best you can find. By having them working with your students, you can gain new ideas and ways of improving your own students.

8. Previous experience of working with the leading figures in the Southern California region, or nationally recognized composers - learning from the best.

9. Watching the positive and negative of a live rehearsal provides valuable information that can easily be transferred to the teacher's own classroom.

10. My attendance at music conferences is most valuable because they address issues on rehearsal techniques, new music, techniques on specific instruments, and they offer exhibit booths with instructional material. 
11. Opportunity to connect with other directors, compare and contrast programs, find new and innovative approaches to have worked for others.

12. Having a strong guest clinician working with a group can be invaluable. For example, we have the Del Bybee Big Band come to Serra each year to work with our jazz band. It is so great for us.

13. Most experience in music workshop activity.

14. Everyone in my ensembles always comes away excited about what they learn from the guest conductor. It reinforces what I do and I learn as well.

15. I get to see, talk to, and watch a lot of different people and activities.

16. Conferences have been where I have learned the most in sessions and been able to network with other teachers.

17. Having a guest clinician gives me new ideas and I observe the quality of musicianship.

18. Attendance come music conferences. Being in an environment where you are with others who are trying to perfect their skill is important. Constant growth has a music educators is essential if we expect our students to grow.

19. Observing other rehearsals. Watching quality teachers conduct rehearsals of their groups is "on the job on" training. This provides ideas that can be used immediately and effectively.

20. Having a clinician work with my group enables me to receive feedback on areas I may overlook. It also gives the students and myself the chance to get another interpretation of the music we are preparing.

21. The more guests I have I get more pointers on how to approach different techniques and the students listen to them more and try the new things I learned from the clinician. 
22. Working on master's degree in music. Coursework directly related to my passion and applicable to teaching activity as well.

23. The good conferences or convention serves to invigorate and rejuvenate as well as educate.

24. Music workshops. As a life long learner, it is to our advantage to keep growing and changing as new ideas and approaches are constantly being used.

25. Attendance at American Band College for several years has been the most valuable because it included a wide variety of appropriate workshops and clinics.

26. Having a guest clinician. Students with hear from others what I have been telling them all day.

27. Having a top rated conductor come in and work with your band is a great learning experience.

28. Serving in professional music organization gave me a chance to interact with other music educators (who I didn't see daily) on consistent basis.

29. I attended music workshops because I need new ideas.

30. The best part of music conferences is been able to network with colleagues and industry representatives. District and school in-services universally have nothing to do with what happens in music classrooms. They are trying to define performance-based assessment while we are doing it already.

31. If the music conference has good clinics they can be valuable. I learned the most from other music teachers usually in an informal setting at a conference.

32. It wide variety of information is available at music conferences.

33. The most valuable experience was gained serving in professional music organization. (Literature, performance practices, etc.). 
34. Kids love guest artists. They hang onto the artist's every word!

35. Music conferences provide the opportunity to network and get a variety of information from others in the field.

36. It is important to meet other teachers at music conferences. This allows for the exchange of ideas, observing workshops, using the new materials, and net working with colleagues.

37. Music workshops being led by knowledgeable professionals actually teaching at the appropriate level.

38. As the only instrumental educator in a small rural district, conferences allow me to interact with other instructors, see new materials, discover new methods, and evaluate what I'm doing.

39. Music conferences provide it wide variety of clinics so you get what you want and need.

40. Music conferences provide the opportunity to talk to other music teachers.

41. It has good to see what other band directors are doing. I got a chance to talk to them about what works and doesn't work for them. That was way more helpful in any inservice or beginning teacher support and assessment activity district provides.

42. Being a musician in an orchestra. An individual can learn so very much by playing in a good ensemble directed by an outstanding conductor. It's the best way to learn.

43. Music conferences. I believe attending performances - concerts, musicals, shows, recitals, competitions (such as DCI) helps me find material to use with my program, and it keeps my "standards of performance" high.

44. Music conferences offer it wide variety of professional perspectives in one place.

45. Having a guest clinician fails two purposes. 1) It gives the students a new perspective, different routine or way to approach music, and 2) it gives me new ideas on how to approach music and some reassurance that I really do know what I'm doing. 
46. Information gained had a direct and immediate effect on my teaching from music workshops.

47. Music workshops are helpful to me for new ideas and can expose kids to new ideas and concepts.

48. Music conferences provide interaction with others. Observations of selected groups for ideas and inspiration.

49. Curriculum development meetings were the best because of the collective ideas of all parties involved. The more input the better.

50. Music conferences were the best because I appreciated the variety of choices and I usually come back with many great ideas and contacts.

51. Music conferences offer new methods and "things". The atmosphere is reinvigorating.

52. Working with others through peer mentoring activities has helped the most. Throwing ideas back and forth clarifies.

53. Additional coursework is the best because I like the additional time and expertise provided by the instructors.

54. Observing other rehearsals is the best because practical application in context is the best way to get ideas and spark new ideas. Modeling is the best teaching method. Learning from a mentor or professional is always a plus.

55. Attendances at music conferences keep you in touch with professional colleagues who are the best source for good information. Also, an important chance to hear the very best student ensembles, etc.

56. Observing other rehearsals. Other successful groups are successful for a reason. I want to provide the most opportunities for my students to succeed. Good practical information outdoes any college course or workshop ever invented. 
57. Music education at the university level sets an academic tone for which to strive as we teach secondary.

58. The experience at a conducting symposium was enormously valuable. One-on-one instruction, access to information and resources, and exposure to concepts and philosophies were very effective learning experiences.

59. New music reading sessions are best because it is hard to listen to all promotional CDs and tapes.

60. Having a guest clinician has helped me professionally and my band the most. It is important to have an experienced and knowledgeable director to work with your group so you can learn how to work that details of the music.

61. New music reading sessions also include contact and interaction with other band directors.

62. I would like more opportunities to network with other music educators at music conferences.

63. Music conferences provide exposure to new techniques, ideas, thoughts, and tools as well as net working with other professionals.

64. Many times I took my students to concerts with me. The experience of hearing PROFESSIONAL musicians provides countless teachable concepts.

65. Observing other rehearsals is best because what works and does not work is best observed.

66. Attendance at music conferences has been the single most valuable (activity) to me through the years. As a young teacher (the only music at the school) is allowed me to contact with other music teachers and share mutual problems. As time has gone by, I still learn new things and share information every year. 
67. I gain a lot of insight from having other people work with my ensembles and getting comments from people who have more experience, knowledge and skill. I find it is very valuable resource.

68. Observing an outstanding educator work with your group gives a new perspective to your own teaching techniques. You can attend class, observe rehearsals, etc. but the best experience is to see new techniques been applied to your bands problems.

69. Music conferences offer a great variety of workshops. The director can choose what he or she wants to attend.

70. I feel it is invaluable to have a master musician/teacher working with my students. It is great to your new ways to say the same thing and beneficial to open your ears to greater musical depth. This experience is directly applicable to my job growth.

71. I learn more by seeing others work, listen to them discuss with kids, see how they manage rehearsal time, and what works and what doesn't. I use anything they had to offer in my own rehearsals. That's why I fell observing other rehearsals is my number one professional growth activity.

72. A conference gives me a large sampling of music education trends. From a conference I can do further research in areas of importance to me.

73. I can choose which workshops best meet my needs. I'll attend workshops that I feel will help me in areas of interest and need. Marching band, conducting, and running a successful program, etc.

74. Having a guest clinician offers great experience for students and can you can see your band from another perspective.

75. I really enjoyed talking to other teachers and learning about new techniques and technology at music conferences. 
76. Observing rehearsals. Being a beginning teacher I want to observe classrooms that work and rehearsals that work. I'm still working on finding my own personal rehearsal style. By watching others I can use the best ideas they've come up with and work them for use in my own rehearsals.

77. I attend music conferences every year and always come away reenergized and with new ideas.

78. Living in a rural area makes opportunities for completing state requirements for preliminary credential holders difficult. Online/distance learning opportunities offer a possible solution.

79. The MENC conference I attended provided me with valuable information on rehearsal strategies, curriculum, literature, as well as contact with my peers.

80. The educational research allows for in-depth study of the topic related directly to what can be done and the classroom. Research can be beneficial in several ways to the conductor and students alike.

81. Music workshops because they are usually presented by teachers.

82. Music conferences. Keeping contacts with fellow music educators. Sharing information on what works and what doesn't and why.

83. Observing other rehearsals puts into practice skills and ideas and concepts. Observations also allows for assessing others and your own effectiveness.

84. I like to learn from the experience of others. Observing them in the "trenches" is the best way to absorb new ideas and approaches.

85. Music conferences. The way it relates to "me" and the help it may be able to give to my program.

86. Observing other rehearsals. See how others work their groups and to compare notes. 
87. Music conferences. The variety of topics covered, and the fact that it is music specific.

88. Music conferences. Interaction is valuable for personal and professional growth.

Conferences offer concentrated accessibility to peers for this opportunity.

89. Peer mentoring activities. I need information from experienced music teachers that my education did not prepare me for.

90. I am always inspired and reenergized when coming away from conferences. Sharing ideas, learning new concepts, and techniques and reinforcing my current practices are very valuable.

91. I picked having a guest clinician because of the time value.

92. I picked having a guest clinician because there's nothing like watching an experienced professional and/or mentor work with your students.

93. I like the "pick and choose" of the areas that I want to attend. It allows me to be selective and I tailor it to my needs.

94. Music workshops are more activity based and I get practical experience. Also, I am surrounded by other musicians eager to learn and improve and have the opportunity to talk with them, share ideas, and renew enthusiasm.

95. Some music conferences have been valuable, because activities such as new music reading sessions, attendance at concerts, and observing other rehearsals are part of those conferences. Allstate honor band, and NCBA fall clinic, etc. are great. CMEA is not particularly good. Too much general music and redundant music performance sessions.

96. Music conferences have varied sessions, usually the best speakers, vendors with the latest stuff, a chance to meet colleagues, and hear great concerts.

97. Workshops provide valuable "hands-on" experience. 
98. Workshops not only introduce new material and ideas but also give us the opportunity to talk to other music teachers.

99. Having a guest clinician. Because oftentimes, a new person on the podium brings a new perspective on music, rehearsal, and my kids.

100. The best information relative to my teaching comes from classes and seminars I've attended at the university level, most notably the American Band College in Ashland, Oregon.

101. Meeting with musicians and music educators to share knowledge and energy. The university coursework is rigorous and gives credit for pay advancement. Usually is a limited and controlled commitment, unlike mentoring and professional music associations.

102. SCSBOA provides a conference/workshop with outstanding clinician's and a good variety of choices.

103. Music conferences have given me the opportunity to learn some techniques from experienced music teachers.

104. Music conferences provide a wide variety of workshops offered at conferences and the quality of workshops.

105. Additional university coursework. The classes I take at American Band College are packed with info. The other directors are there to improve and the atmosphere is professional and positive! The staff is the cream of the crop!

106. There are many different sessions, like "one stop shopping" for my needs and interest. Every time I go to the Bay section or the state conference, I received a wealth of information. Also, I get to interact with fellow music educators, catch-up, trade stories, and so on. It reenergizes me. 
107. New music reading sessions. The choice of literature is most important decision because it motivates kids, determines teaching lessons, concerts and performances and festival effectiveness.

108. With guest clinician, not only do the students benefit from the information, but also I find new ways to teach concepts and rehearse the ensemble.

109. Observing other rehearsals allows me to see firsthand what works and what does not. Observing student's faces while a certain strategy is being used.

110. Attendance at music conferences provides the opportunity for collaboration with other music teachers.

111. Music workshops are very subject specific and do not take general (shotgun) approach to a topic.

112. One learns best from observations of master teachers in real settings.

113. I have learned much and clinic workshops that directly improve how I perform my job.

114. A "working classroom" provides the optimum opportunity for personal and professional growth. Observing other rehearsals.

115. New music reading sessions because we always need to find new charts.

116. Being a guest teacher because of sharing, opening attitudes to help.

117. Conferences provide a wealth of information.

118. It's important to attend conferences/workshop is/conventions because of the info available, contacts/relationships you can build, concerts you can go to, and after hours drinking with your buddies!

119. Music conference activities are varied and there is always something of interest to learn.

120. Having a guest clinician gives you a chance to sit back and listen, as well as evaluate. 
121. By observing other rehearsals I am introspective about my own teaching and become motivated to change my way of teaching.

122. American Band College is a wonderful pedagogical study for directors at all levels of their careers.

123. In music workshops I can frequently meet and talk with professionals who have teaching experience in areas other that my own. It seems my learning curve is greater and I take home practical information and techniques I can apply.

124. Music conferences provide opportunities for networking to setup solo/ensemble festivals, exchange concerts, visitations/observations etc. Easiest to set up at SCSBOA conferences plus the sessions can be great learning.

125. Conferences provide more variety and approaches.

126. I have learned more by observing good and poor teachers than I did in most of my university classes. The things learned in university classes rarely applied to the actual teaching.

127. I love watching others as I observe and take in the things I like and then I make it to my own.

128. New music reading sessions. As a musician, I realize I must keep my own musical skills sharp.

129. I found music conferences to be of good and opportunity for me to bounce ideas off of my peers as well as find out what things really work from people who really use them.

130. Reading sessions given me the excitement to do new works.

131. Attendance at music conferences like CBDA, Midwest and CMEA are quite helpful. Watching rehearsals of honor groups and attending concerts are No. 1. Clinics by good clinicians are also helpful. 
132. I chose music conferences due to my regular attendance at the Western international band clinic every year in Seattle. We read new music, we networking, watch guest conductors - all of which is very valuable.

133. Guest clinician's provide a direct benefit to my students as well as myself. I regularly invite 2-3 clinicians per year.

134. Music conferences have a very large selection of workshops/clinics. The more choices the better.

135. As I am the only music teacher at my school, I am very isolated professionally for most of the school year. Music conferences are great way for me to touch base with other music educators and share ideas with them.

136. I have learned more from rehearsals (participating and observing) than anywhere else.

137. Serving and professional music organization teaches me how to perform at the highest level.

138. Watching an outstanding band director at work seems the best way to pick up the tricks of the traded at really work.

139. To any music teachers stagnate forever at grade $3-31 / 2$ "literature." There's a real music world out there waiting to inspire us. We must grow as musicians.

140. Having a guest clinician is directly relevant and helpful and has direct application.

141. Music conferences are chance to collaborate with other music educators and learn new material/strategies on how to teach.

142. You always learn more as the teacher than as a student. As a guest, I think you "gear up" and study the score more and can be "on" for a brief period of time. This is a lot different than looking at the same folks every day. (Being a guest teacher and/ or clinician). 
143. I have just completed my master's degree and instrumental conducting. I am a much better teacher now than before I started the coursework.

144. I chose observing other rehearsals because directors are not as inhibited in their own classrooms, and it is an excellent learning situation.

145. I picked new music reading sessions because I have been out of music for 11 years have missed a lot of new music.

146. Peer mentoring activities. I received my training in elementary classroom music teaching. I am a piano major with a good background in choral works. I never played in band and received no classroom experience with a master teacher in band. I would love to work with master teacher watching them work with a group, having them watch me with a group and discussing rehearsal techniques.

147. Depending on what conference you go to. I find conferences like Midwest stimulating and really give me a sense of whereon at and where I need to be headed with my band program.

148. New music reading sessions. Because it is practical, not esoteric or theoretical, and relevant to each individual's situation.

149. Having a guest teacher with my weakest area (choir) was terrific for me and my students.

150. Attendance at music workshops this year -- very valuable!

151. Music conferences provide the widest variety of information.

152. At this stage of my career I find that observing other people do what I do is often more valuable than a prepared presentation at a conference.

153. Music conferences gives me new ideas to bring back to the classroom and it will give me other music teacher's opinions of new concepts. 
154. I go to Symphony concerts, the Bach festival and jazz clubs often. Observing professionals perform and listening to music gives me inspiration to make a high school ensemble like the pros.

155. Having a guest clinician work with my group helps me to find new ways to present material to my students. I'm able to see what works and student's reactions to new/different methods.

156. Music workshops. Hands-on experience is best for me, as long as it is in a practical setting.

157. Having guest clinician work with my groups provides the highest education for me and my students. Over the years, this has been the most productive.

158. Music conferences provide a variety of learning opportunities. As programs grow each year there may be a different focus for my individual development as a teacher. Conferences give me the opportunity to pick and choose necessary information and personal interactions.

159. It is much easier for me to evaluate what is needed in an effective rehearsal. I can, or objectively, see what works and what doesn't. I can also get new ideas for teaching a concept.

160. Having another person come in and work your group is an eye opening adventure; it educates you, your students, and helps your overall program.

161. Workshops are usually hands-on, a practical and smaller number and conferences.

162. An excellent way to stay current and observe different ways to the effective. Music conferences. 
163. By taking the university or college course that interest me, I will make myself get the most out of the class. I can pick the area that I need to help me to become a better teacher.

164. Having a guest clinician is a great help for students and educators. This is most valuable because it is on the spot information with immediate feedback.

165. Conferences are most pertinent with flexible choices and time.

166. Having a clinician come and is refreshing for the students as well as myself. You get another expert in the classroom.

167. Music conferences provide a wide variety of topics to select from.

168. Taking additional university courses worked on making me a better music teacher in the classroom. They emphasized knowing basics of all instruments and rehearsal techniques.

169. Having somebody work with my group on specific needs gives me the most information about what I am doing well and ways I can prove my teaching.

170. Music conferences. Guest clinicians -- new products - the chance to solidify strengths and improve weaknesses.

171. Music workshops. I had the opportunity to interact with other band directors. I got the chance to work on my conducting with Keith Brion and Mitch Fennell. I was introduced to new literature.

172. Music conferences generally encompass workshops, reading sessions, curriculum development, research, and current relevant and nonmusical educational issues. In addition, they are a great opportunity for networking and exchange of ideas.

173. Music conferences because I heard professional musicians from around the world and concerts and clinics, rehearsals and seminars. 
174. Music conferences/workshops by local music associates tend to deal with immediate problem solving and useful material that can be used in your program.

175. Music conferences, attendance at concerts and observing other rehearsals and hosting guest clinician enabled dialogue between teachers.

176. Having a guest clinician. I learn a lot from other professionals and I get to see other approaches to problems.

177. District supervisor (Andy Osmond) in Long Beach unified school district was able to specifically tailor the workshop to our needs and requests.

178. Attendance at concerts stimulates me to greater actions.

179. Music workshops because they are hands-on, fund, exciting.

180. Music conferences. Stating current, interaction with familiar subjects and related areas. Staying abreast of innovations. What works at other locations and how. Inspiration to charge my batteries.

181. Attendance at music conferences especially the Midwest in Chicago - very informative.

182. Observing other rehearsals. Getting fresh ideas or being reminded of old ones by watching another teacher in action stimulates a lot of analysis of what I do the classroomand why.

183. More than anything else, conferences have revitalized me and sent home with new information to assist me with my instruction.

184. Attendance at concerts. I'm also a professional performer - I get more out of attending professional concerts (listening to music) than attending a conference or workshop (listening to someone talk about music).

185. I have had very valuable and rewarding experience is at music conferences. It is important to collaborate with other music teachers and to attend clinics. 
186. Exposure to new literature at music reading sessions and hearing other ensembles of similar age and experience as my group. Having guest clinician. Having a fresh face reemphasizes what is going on in our program on a daily basis.

187. Conferences allow opportunity to attend sessions specific to my area of interest, interact with colleagues, listen to other groups, expand repertoire knowledge.

188. I feel that observing other educators in a rehearsal setting gives me the most applicable ideas and is most helpful.

189. Music conferences. Sharing of ideas with other music educators, hearing/seeing what others are doing in area of music education. Usually at conferences there are choices of clinics, meetings to attend, (so) one can attend clinics they find most beneficial.

190. I learn a lot when I attended the Bay section CMEA clinics and also when I attended the Midwest and Orchestra clinic.

191. Serving in professional music organizations. I have gained a tremendous amount of advice and information for my colleagues who share similar situations. It may not be directly presented, but I absorb attitudes, perspectives, and ideas from the experiences we share. District and county level workshops do not usually even have a concept of what we do.

192. Having guest clinician because it is hands-on. Relevant and meeting specific needs.

193. Having guest clinician because it is good to get different perspective and watch somebody with possibly different techniques for working on a problem. Also, good for students to hear someone else say the same things and give objective perspective.

194. Music conferences. As a band director, we must keep up with many musical activities including computer music, music appreciation, jazz, marching and concert band, 
beginning band, and all the instruments. The only place to do this is the CMEA in service.

195. Currently I'm working on my masters in music education and I found the coursework invaluable in improving my teaching.

196. Music reading sessions provided the most direct impact on my daily work.

197. I have learned and continue to learn a lot about music education from SCSBOA and their expert mentor teachers.

198. Going to concerts is inspirational to any musicians -- the electricity live music is unique. The motivation is what kids need nowadays.

199. Conferences provide a large variety workshops on different instruments, conducting etc.

200. Attendance at concerts provides direct communication in the language of music itself.

201. Being a guest teacher/clinician. I've been a guest conductor for the Southwest division of the Iowa bandmasters association and felt a tremendous feeling of accomplishment and fulfillment. I have also served as a judge for the solo and ensemble contest as well as large group (band and jazz, and marching band) contests.

202. I have attended the CMEA conferences for years and always learn something.

203. Music conferences. So many choices of topics, I get to talk to other teachers and get lots great ideas and vendors.

204. Music conferences. More variety of subjects and I can choose which sessions to attend.

205. Music conferences. CBDA provides the opportunity to exchange ideas and program ideas with others doing the same job I am. Real answers to real problems.

206. Music conferences (especially national/international level) allow for networking and peer support, as well as professional experience in music education. 
207. Having guest clinician provides the chance to see how others work with your group that you see day to day.

208. Mentor teachers have offered experience I do not have, invaluable.

209. Observing rehearsals helps me learn how effective different teaching techniques are.

210. Music workshops provide hands-on experience that cannot be beat.

211. Having a guest clinician. I have always thought we get to hearing the wrong things from our groups. We need fresh ears and eyes. It is better to have someone watch and listen than help fix things in how we teach -- not just this piece of music.

212. Music conferences. Subject area conferences tend to target "hot topic" items relative to better teaching/ performance. The ability to key on specific topics relates to your ability to diagnose and analyze your own needs.

213. Personally, observing educators' work and their classrooms is very enlightening for me. I can watch conducting styles, discipline techniques, and overall rehearsal tips. From there I can analyze my own teaching and directing and see what I can use with my own groups.

214. Guest clinician. I find out what others are hearing in my group and how they deal with it. It goes to the core of what I don't know.

215. Having guest clinician and observing other rehearsals are a toss-up. When I observe honor band conductors each year at the All-Southern and All-State, I always learn a great deal and come away with ideas on how to do things better. When I bring someone in to work with my ensemble, I always learn something and get a different perspective on not only how my group is doing, but where it needs to go to reach a new level.

216. Music conferences concentrate a lot of knowledge in the same area in a short period of time. You have many choices as to which sessions you want to attend. 
217. Being a guest teacher and/or clinician. Nothing challenges your ability to teach like being in front of an unknown group for a short period of time. You have precious little time to transmit both your knowledge and love of music, so you really have to have a good handle on your skills.

218. Participating in peer mentoring activities. Learn from their experience and make good contacts for the future.

219. I have always picked up one or more techniques or strategies while observing other rehearsals.

220. When I began teaching I was fortunate to have regular observations by the district supervisor of fine arts. He provided immediate feedback as to what went well and how to fix that which did not. He was also able to "clinic" the group -- mostly to demonstrate rehearsal techniques for me. I believe this allowed me the fastest growth as teacher. I had a private teacher if you will. 
APPENDIX F:

COMMENTS TO MUSIC EDUCATION ORGANIZATIONS 


\section{Do you have additional comments for organizations that provide professional growth activities of high school instrumental music teachers?}

1. Yes, have enough handouts and organize your workshops better.

2. More is needed about those areas directors must have knowledge in beyond music preparation: like boosters, public relations, fund-raising, dealing with parents, marching band, setting policies and procedures that work, etc.

3. Leave theoretical approaches to music (arts) education to colleges - concentrate on the practical (how to).

4. Organized mentoring sessions have seemed to me to be contrived.

5. Making sure lectures are top-quality and thorough. Making sure the lectures represent the needs of the membership.

6. Neighboring universities are an incredible resource for both teachers and students. There seems to be a greater high school to university relationship in the East and Midwest than in Southem California. San Diego State University and Riverside City colleges are exceptional at "reaching out."

7. Many high school students need a find arts credit -- what and how to teach. Music appreciation? Guitar class? Where can teachers get materials for a general music class for high school level?

8. There must be much more support for new teachers. They are floundering!

9. Keep it relevant to our everyday needs, as opposed the esoteric. For example, the clinician from Florida State (music ed.) Charles Hoffer? Now that was relevant.

10. MEMC and CMEA are wonderful organizations and provide service to our music education community.

11. CBDA has been the best conferences for me for the last 25 years. 
12. Many workshops are bogus sales pitches for products - what an insult and waste time/money.

13. Lower prices. Not all teachers get budgets.

14. Organizations that provide professional growth will continue to see better and more effective music programs that (sic) will prosper.

15. Have great clinics with nuts and bolts ideas that work in real world.

16. Often those of us in outlying areas never know what's going on until it's too late. Summer workshops with available/affordable accommodations are greatly needed.

17. I'm tired of always having "introduction to ..." workshops, especially related to technology. Also, I don't like having training workshops for things our district can't afford.

18. Help them to learn how to manage their bands, with uniforms, funding, reeds, simply how to organize the program.

19. How about seminars for new music teachers? The duties are enormous and we need ideas for discipline, fund-raising, accounting, etc.

20. They all should visit and see as many groups as possible. The interaction works wonders to keep on an even keel. Most teachers in this area are too busy to even communicate with each other, much less work together musically.

21. It sure helps to have choices whenever activities are offered.

22. Make it very doable! Practical, usable resources are a big plus. Don't expect us to rewrite everything we've learned or done. (Not that we need to). Ready to use! Practical solutions to everyday dilemmas.

23. California has a professional growth requirement for all clear credentials secured after August 1985. It would be helpful for a participation certification system to be established 
for conferences, workshops, etc. (150 clock hours).

24. Instrumental instructors need to make a stand regarding positions as band director (marching band) and Orchestra director and providing staff with booster funds. It is absurd.

25. Find a way to get district or school financial support. Teachers do not make the money necessary to subsidize their programs.

26. Communication and convenience are vital!

27. I enjoyed conferences that SCSBOA put together. You're able to get a lot of information from many sources in a short amount of time.

28. They should continue to provide growth activities - with our busy schedules as teachers, these conferences are often our only way to observe new ideas and techniques.

29. We don't learn all we need to know during undergraduate studies. As California establishes standards for education, we as music educators must establish and except assessment standards that are explainable to the non-music public.

30. Must be able to use the material.

31. We are unique in find arts. Typical professional growth classes do not work for us.

32. The focus on instrumental teachers as beginning teachers should be on administrative duties - forms and procedures. Many of the BTSA coursework just takes up my time from planning and doing administrative tasks.

33. "Hands - on" activities related to our subject are much more effective than forcing teachers to learn about subjects outside the area content.

34. I would recommend district workshops that include all instrument teachers. I would emphasize the communication between each level (elementary, junior high school, high school) regarding entrance and exit skills. 
35. It is very important that you stay active as a musician. I make an extreme effort to be active as a performer in order to stay honest and current as a conductor during my own classroom rehearsals.

36. Military reserve bands: air National Guard, Army, and National Guard.

37. I appreciate pedagogical information that I received, however, what seems to be lacking is information regarding classroom management, discipline, and grading.

38. Have a good mix of practical and ideal sessions and how to get one's group to the ideal situation.

39. Screen you're clinicians!

40. In smaller districts the locally sponsored in-services rarely relate to music and are waste of time!

41. Get a reality check! "Intonation of professional bassoonists" is not the majority priority. Be more demanding of what you expect we can learn! And use in our classroom now.

42. Sessions run by fellow music educators guarantee that the information has been tested and proven in a classroom. Sessions run by those who claim to have the latest new educational idea tend to be the least useful.

43. CMEA usually has some decent seminars/conferences. They have too many (sessions) going on at the same time.

44. SCSBOA conferences are both diverse and focused on elements of music education.

45. Emphasize practical style and rehearsal techniques.

46. SCSBOA can be commended for attempting to meet the needs of its members.

47. Band reading sessions with representative lists that are graded is very valuable! Grading in music programs. Leadership techniques for band members.

48. Stop catering to the already great programs. Find small schools in "East Butt Crack, CA" 
something to help us. Example of SCSBOA session "what to do with my 9 tubas in marching band" (true statement).

49. Too expensive especially MENC!

50. Those of us that have been in the profession for years are not interested in clinics for young inexperienced directors. Gear something for us.

51. Observe, observe, observe - share ideas with your peers.

52. At times, many organizations can be unapproachable by inexperienced directors. Not always, not everyone. Also directors in extreme outlying areas find many events inaccessible. Maybe organizations should subsidize retired people traveling to remote areas.

53. Reading sessions are wonderful as are lists of music with ratings and helpful ideas about selecting music for a particular group, difficulty, CDs where selections may be heard, and ideas for musical interpretation.

54. Work hard to get every member to attend! Do better than the $80 / 20$ rule possible ( 80 percent of the work done by only 20 percent of the organization).

55. Have more hands-on activities, demonstrations.

56. Make the relevant to the teacher's situation!

57. Colleges need to actually prepare students for the teaching world. For instance many band directors also need to fund-raise and other things that are realities in the classroom.

58. I'm going to my first music inservice in March. I'll know more when I returned.

59. I would like to see focus on excellence in performance. Sessions talking about the systematic approach to fundamental development and holding students responsible for their work. Focus on fundamentals of playing various instruments.

60. I truly wish college students studying music education would get out of their classrooms 
more often to observe the good (and bad) teachers out there. I would be delighted to host them!

61. Unfortunately most courses that I have attended not apply.

62. They need to focus on organization, musical expression, and music choices. Competition must be eliminated or de-emphasized. Collegial relationships must be maintained.

63. Give specific guidelines and instructions of desired content to clinicians and presenters.

64. Activities should involve participants as much as practical. Demonstrations, hands-on, we've all been through lots of lecture and "sage on the stage" time.

65. Instrumental music teachers must penetrate the subject area. Further study whether in a degree program or independently.

66. CMEA, MENC, and IAJE all have excellent clinics for teacher growth. Many music festivals offer excellent clinics for teachers.

67. Send more mentors!

68. I really enjoy going to the North section fall CMEA conference in Redding and state conference. I also learn a lot from taking my students to Northern California honor band and chorus, solo and ensemble festivals etc. And watching directors work with kids. I've been teaching band for five years and I've learned from my mistakes - but it takes a while.

69. CBDA is doing a great job with their conference as of late!

70. NAMM - excellent

71. In "administration" you can ask any question and get everyone's "best" answer. In music if you ask a question colleagues judge you as "unknowing" and don't give their "best" answer because they must compete against you on Saturday. This "mindset" held music education back -- hurts kids - and does not support novice teachers. 
72. They might consider the academic calendar and schedule workshops or conferences at a more convenient time of the year. During the first two weeks of the school year is not good time.

73. The practicality is important, as is relevance to our digital age. Computer music technology needs to be taught hands-on and one-on-one.

74. Keep an open mind!

75. Including music faculty in on-campus full faculty in services is a waste of time.

76. We need to develop more contacts with the "working" professional musicians and include these highly skilled players in our process.

77. Make sure it applies to what we doing a classroom every day and those we can use it right away.

78. They should address the following issues: standards-based curriculum, budget/advocacy, communication among neighboring teachers, improvement of teaching methods (i.e. getting the most out of rehearsal time).

79. Guest composers of current repertoire with performing groups; i.e. Ticheli.

80. The American Band College at Southern Oregon University each summer - wonderful material, clinicians, conductors and music reading -- it's the best!

81. Hearing or seeing the new quality literature would be very helpful.

82. Do more to show us how to effectively advocate for music. Less on competition (especially marching band) and more on music education. Historical, performance practices, theory! Require all to have string education ability and background!

83. One of the biggest parts of any program are the parents of our students. There should be an inclusionary effort to enlighten and educate parents of a music teacher's work. Advocacy and value of music is currently disproportional. One of the most frustrating 
and abusive traits of teaching here in California is the credentialing program. It seems an insult to every educational institution in the country outside California. I have seen very effective, competent teachers quit because of the imposition upon their careers.

84. Don't assume that all the care about is having a winning band.

85. The more we can do to offer high quality clinics for teachers the better. The most organized and thought-provoking organization I have recently attached myself to is the International Association of Jazz Educators. They do it right!!

86. Provide a variety of sessions.

87. The Midwest Band and Orchestra Directors Clinic is one of the most comprehensive -SCSBOA should take note.

88. Be more active!

89. I am currently searching for information about incorporating more technology into my curriculum. It is difficult for those of us who graduated in the early ' 80 s to get the experience and ideas we need without great personal expense.

90. The out what the actual teaching assignment of the audience is and make it relevant everyday class time.

91. I encourage all music teachers to get involved in SCSBOA and make everything they want to be. It will meet their needs, if they let it.

92. Make it more hands-on. Visuals work very well -- but just speaking to high school kids is lost and meaningless unless it includes activities and/or participation.

93. The San Diego Symphony.

94. I do not appreciate it when you attend a conference session and the presenter is trying to sell you something.

95. Bring in guest clinicians. Much can be learned by watching them teach your own students 
and observing the student's reactions.

96. I wish there was more!

97. Of all problems faced by all high school band directors schedule is the most critical! Band directors must be aware and involved in any discussion involving requirements and scheduling (block or any kind is not good -- semester block is deadly).

98. I am very disturbed at the lack of professionalism in the SCSBOA competitions. It would be extremely beneficial to Southern California high school band if the universities and other professional music organizations could provide a positive, music-based competition circuit for field show, parade, and concert competitions. We are currently "stuck" with SCSBOA or deciding not to participate in competitions.

99. Need to provide more guest artists and conductors.

100. There is no substitute for experience. Music is hard to learn from a book. I would like more opportunities to react with more experienced instrumental music teachers.

101. Offer great for the hands-on workshops with less year-to-year repetition as SCSBOA does.

102. We need people to come to our school and observe what we do. Tell us what's wrong and give us ideas on how to improve. Watching someone else doesn't always help.

103. It's important that they provide a wide spectrum of topics allowing for the diversity of the attending population.

104. We, instrumental music teachers, need more release time to do observations of one another. Also, the in-service of professional growth needs to be more consistent (such as once a month).

105. The director must be involved somehow or the new knowledgeable will not be internalized and therefore, used. 
106. I believe all conferences should offer sessions on the expressive qualities of making music as well as sessions with professional musicians giving clinics that are designed to help music teachers teach more effectively.

107. These organizations are going to have to teach the teachers how to keep the arts alive in an environment that is increasingly relying only on standardized test scores to determine the success or failure of schools. It's scary.

108. I think the SCSBOA conferences are valuable, particularly for new teachers. This past winter conference was quite good! I Thought the Impact Program was good to! However, it did more for my marching program than concert. Things discussed (ways to fix problems) were more related to marching bands. I could not attend the summer '99 sessions and perhaps that was when the discussions for concert literature, conducting, etc. took place. 